
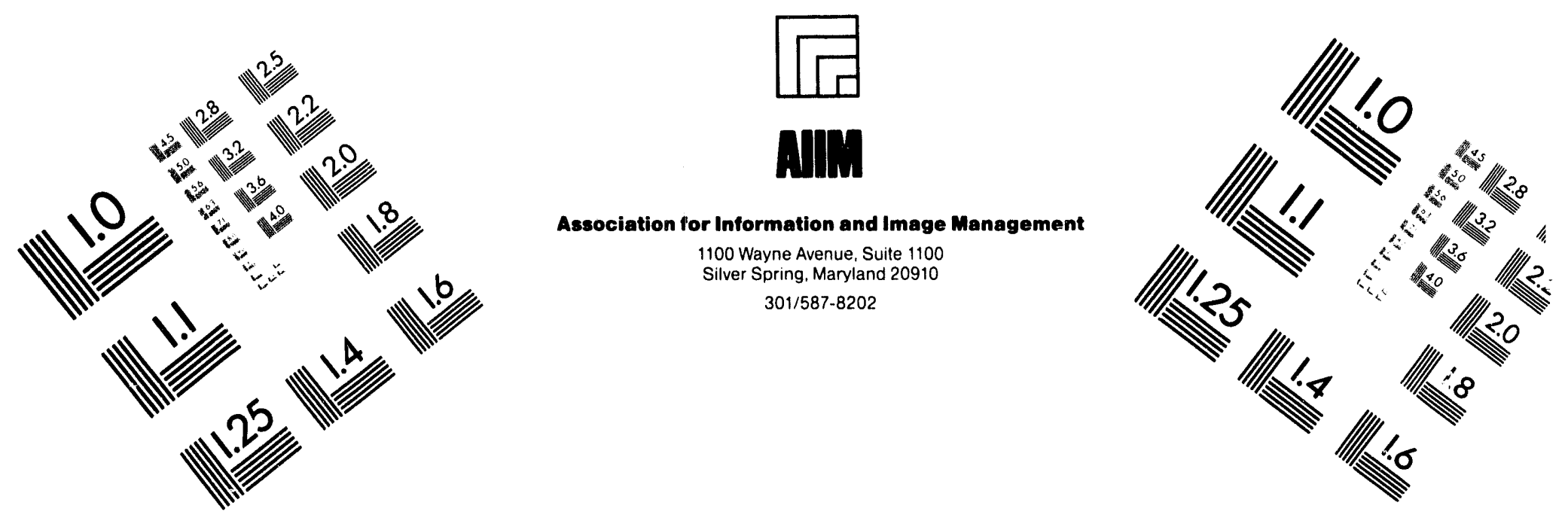

\title{
Centimeter
}

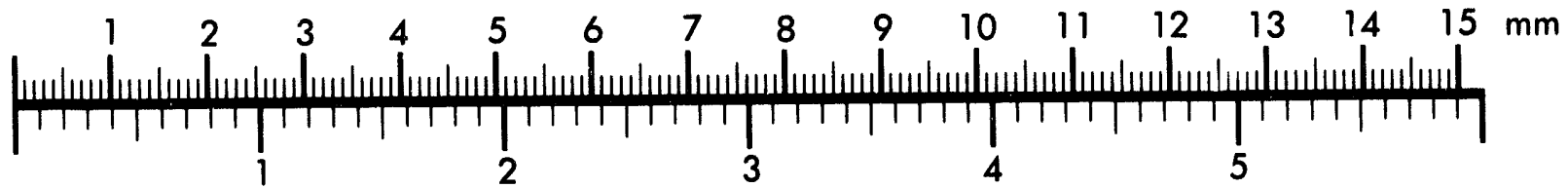

Inches
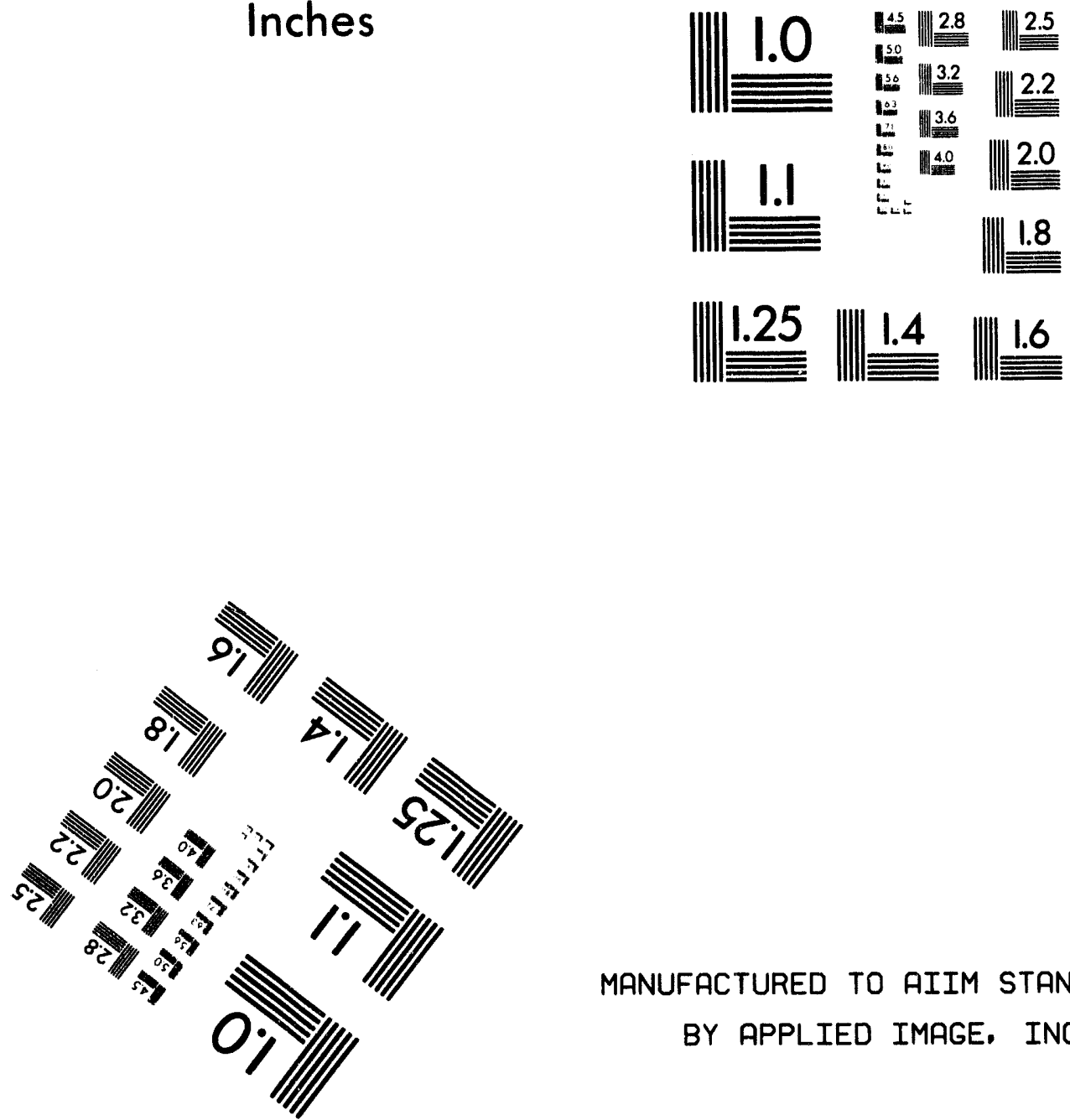

MANUFACTURED TO AIIM STANDARDS

BY APPLIED IMAGE, INC.

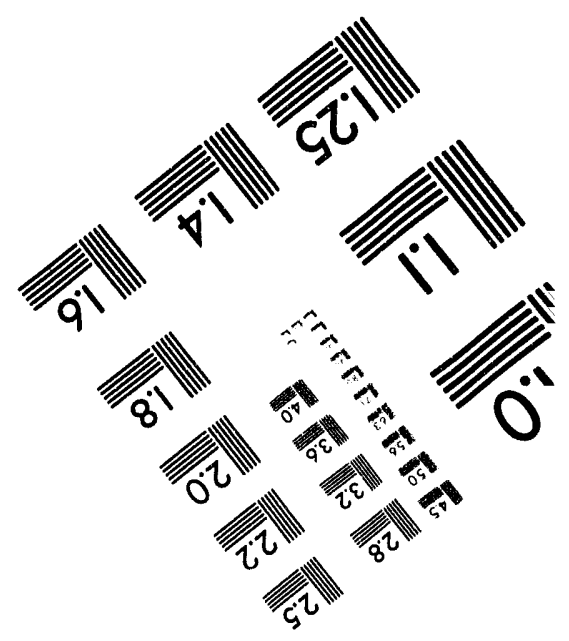



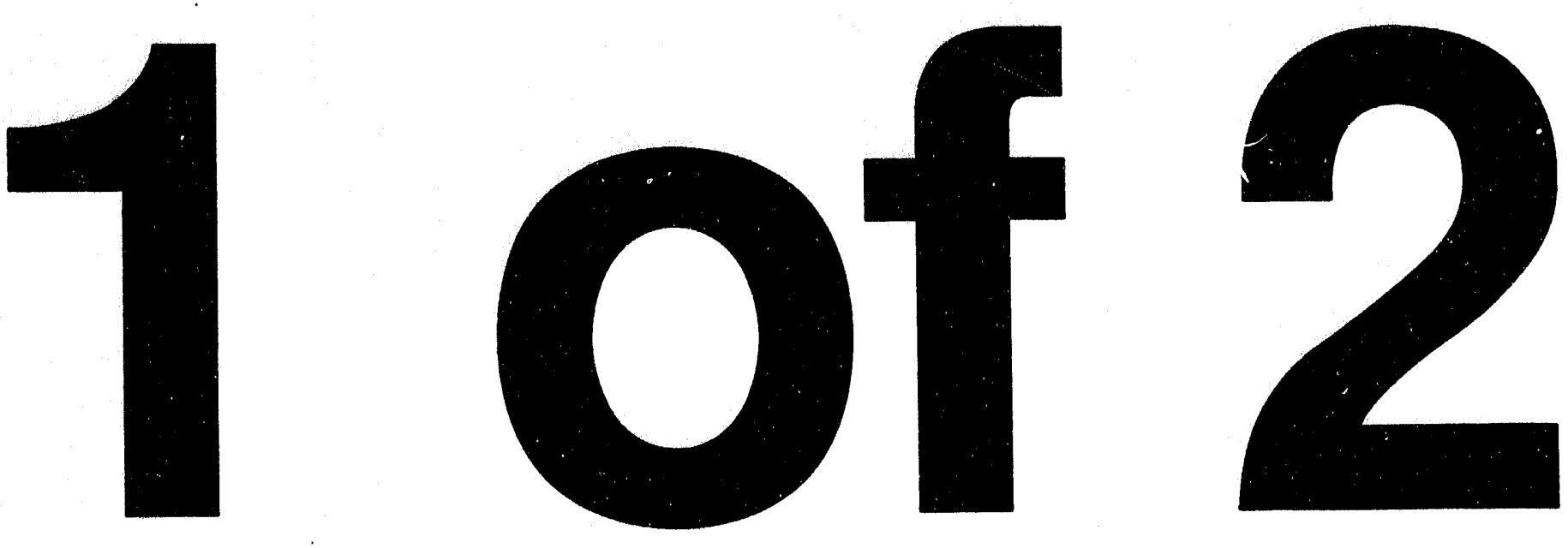


\section{The Climate Change Action Plan: Technical Supplement}

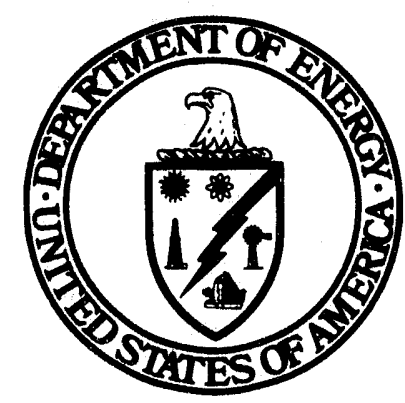

March 1994

Coordinated by

U.S. Department of Energy

Office of Policy, Planning, and Program Evaluation 1000 Independence Avenue, S.W.

Washington, DC 20585 
This Technical Annex documents the assumptions and parameters used in developing the supporting analysis for the Climate Change Action Plan (the Plan) issued by President Clinton on October 19, 1993. The Annex is intended to meet the needs of independent energy and environmental analysts who wish to better understand the Plan, its analytical underpinnings, and the events that need to transpire for the emissions reductions called for in the Plan to be realized.

The Plan documented in this Annex reflects the outcome of a wide-ranging effort by Government agencies and interested members of the public to develop and implement actions that can reduce net greenhouse gas emissions in the year 2000 to their aggregate 1990 level. Based on agency and public input, the Climate Change Mitigation Group, chaired by the White House Office on Environmental Policy, developed the Plan's content. Many of the actions called for in the Plan are now underway, while others are in advanced planning pending congressional action on the fiscal year 1995 budget.

The analysis supporting the Plan represents the results of an interagency effort. The U.S. Department of Energy (DOE) was responsible for the integrated analysis of energy-related options, based on the analysis of individual energy-related options by DOE, the U.S. Environmental Protection Agency (EPA), and the U.S. Department of Transportation (DOT). EPA led in providing analysis for actions related to methane, hydrofluorocarbons, and perfluorocarbons. The U.S. Department of Agriculture (USDA) led the analysis of carbon sequestration actions and cooperated with EPA in the analysis of actions to reduce nitrous oxide emissions.

While this Annex incorporates sufficient background information for most purposes, other reference materials contain additional relevant information. The Annual Energy Outlook 1993 (AEO93) ${ }^{1}$ provided the basis for the energy consumption forecasts used in the Plan analysis. The AEO93 and extensive documentation of its assumptions and models ${ }^{2}$ can be obtained from the Energy Information Administration (EIA), National Energy Information Center (202-586-8800). Additional documentation for the Integrated Dynamic Energy Analysis Simulation (IDEAS) model that was used to determine the integrated energy impacts of the Plan is available from the AES Corporation (703-358-0512). Additional documentation related to modeling of non-energy actions can be obtained from EPA, USDA, and the staff contacts listed in Appendix B.

1. Energy Information Administration, Annual Energy Outlook 1993, DCE'EIA-0383(93) (Washington, DC, Jan. 1993).

2. Enorgy Information Administration, Assumptions for the Annual Energy Outiook 1993, DOE/EIA-0527(93)(Washington, DC, Jan. 1993). 
I. Origins and Context of the Climate Change Action Plan $\ldots \ldots \ldots \ldots \ldots \ldots \ldots$

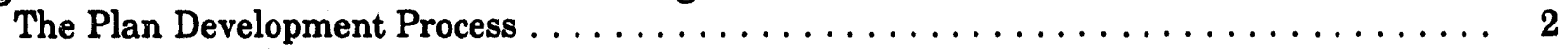

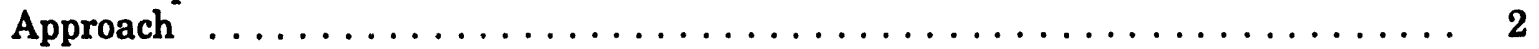

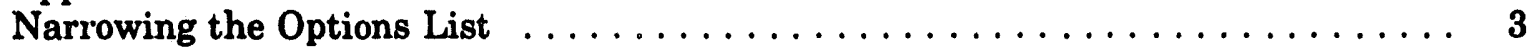

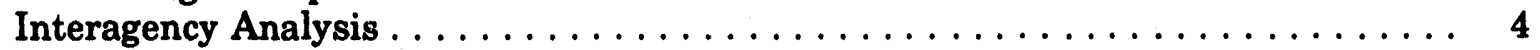

Integrated Modeling of Energy Sector Actions $\ldots \ldots \ldots \ldots \ldots \ldots \ldots \ldots$

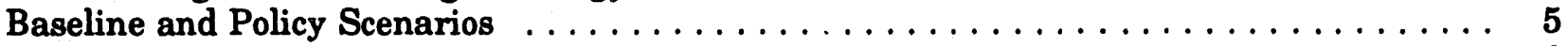

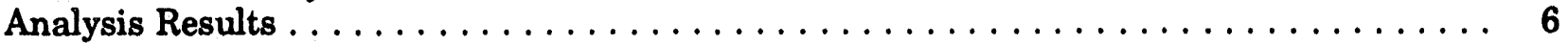

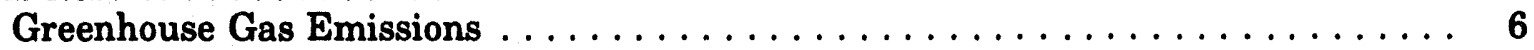

Energy Consumption and Production $\ldots \ldots \ldots \ldots \ldots \ldots \ldots \ldots \ldots \ldots$

II. Development of the Administration Baseline $\ldots \ldots \ldots \ldots \ldots \ldots \ldots \ldots \ldots \ldots \ldots$

The Administration Baseline Scenario for Energy . . . . . . . . . . . . . . 11

Economic and Technology Assumptions for the Energy Sector $\ldots \ldots \ldots \ldots \ldots \ldots \ldots$

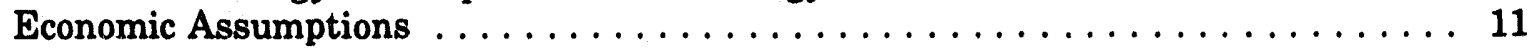

Transportation and Military Energy Use . . . . . . . . . . . . . . 12

Environmental Controls and Technology Costs in the Utility Sector . . . . . . . . 13

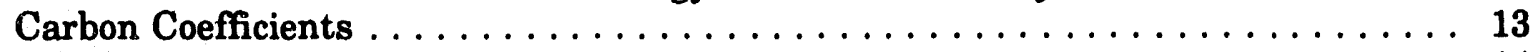

Baseline Assumptions $\ldots \ldots \ldots \ldots \ldots \ldots \ldots \ldots \ldots \ldots \ldots \ldots \ldots \ldots \ldots$

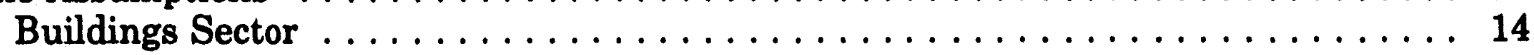

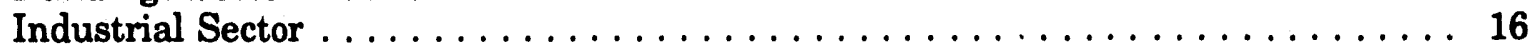

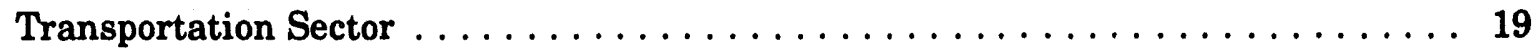

Electricity Generation . . . . . . . . . . . . . . . . . . . . 20

Additional Baseline Policies Affecting Energy-Related Emissions . . . . . . . . . . 23

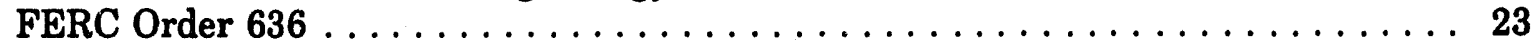

Efficiency Standards in the Energy Policy Act of $1992 \ldots \ldots \ldots \ldots \ldots \ldots \ldots$

Energy Policy Act Research and Development Programs . . . . . . . . . . . . 23

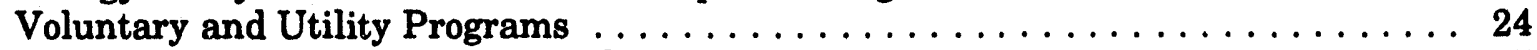

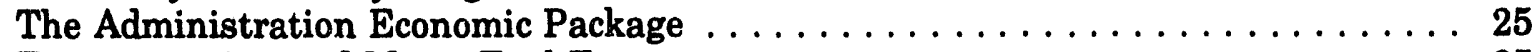

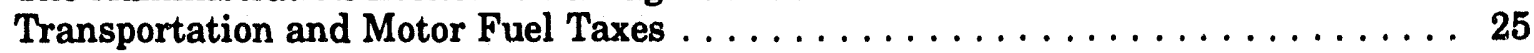

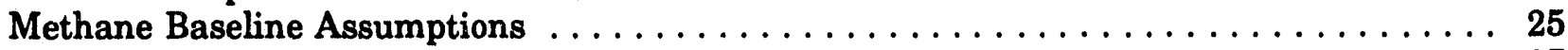

Nitrous Oxide Baseline Assumptions $\ldots \ldots \ldots \ldots \ldots \ldots \ldots \ldots \ldots \ldots \ldots \ldots \ldots \ldots \ldots \ldots$

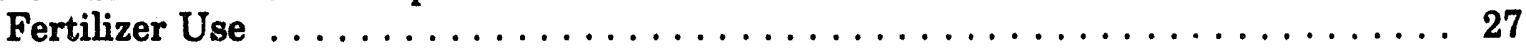

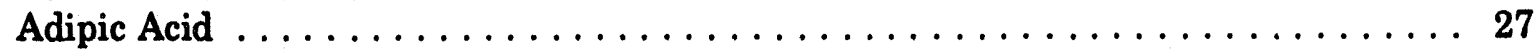

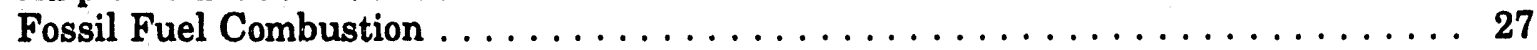

Hydrofluorocarbons and Perfluorocarbons Baseline $\ldots \ldots \ldots \ldots \ldots \ldots \ldots \ldots \ldots$

Baseline Emissions Estimates . . . . . . . . . . . . . . . . . . 28

Methodology for HFC and PFC Emissions Estimates $\ldots \ldots \ldots \ldots \ldots \ldots \ldots$

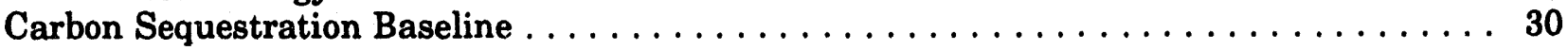

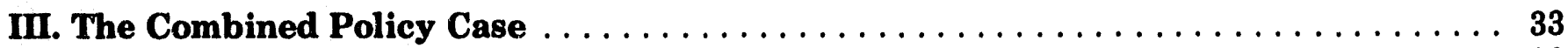

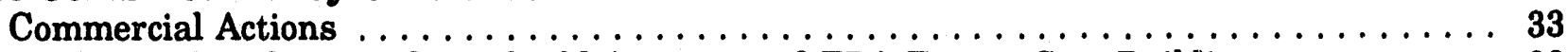

(1) Coordinate DOE Rebuild America and EPA Energy Star Buildings . . . . . 33

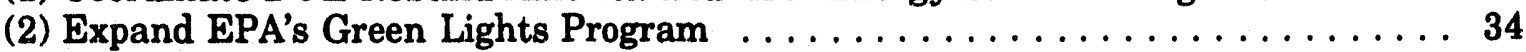

(3) Establish State Revolving Fund for Public Buildings . . . . . . . . . . . 34

(4) Expand Cost-Shared Demonstration of Emerging Technologies . . . . . . . 35

(5) Establish Energy Efficiency and Renewable Energy Information and Training

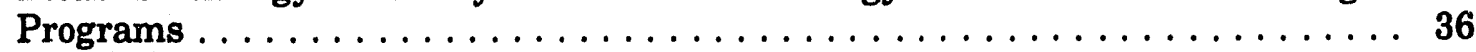

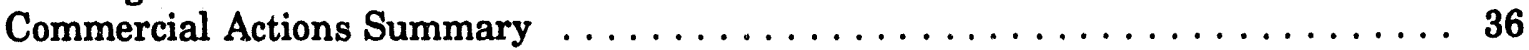




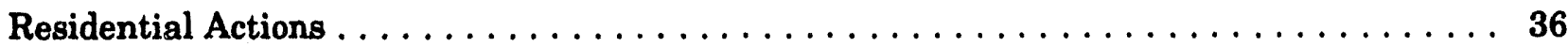

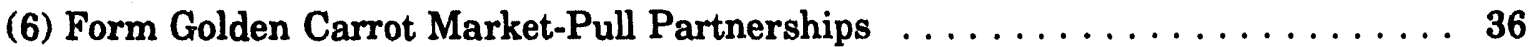

(7) Enhance Residential Appliance Standards . . . . . . . . . . . . . . . . 37

(8) Promote Home Energy Rating Systems and Energy-Efficient Mortgages . . . . . 40

(9) Expand Cool Communities Program in Cities and Federal Facilities . . . . . . . 40

(10) Upgrade Residential Building Standards . . . . . . . . . . . . . . . . . 41

(11) Create Energy Efficiency Programs and Housing Technology Centers . . . . . 41

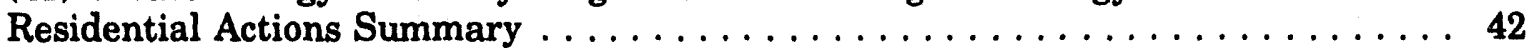

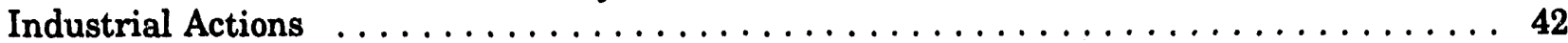

(12) Create a Motor Challenge Program . . . . . . . . . . . . . . . . 42

(13) Establish Industrial Golden Carrot Program for Industrial Air Compressors,

Pumps, Fans, and Drives . . . . . . . . . . . . . . . . .

(14) Accelerate the Adoption of Energy-Efficient Process Technologies,

Including the Creation of "One-Stop Shops" . . . . . . . . . . . 45

(15) Expand and Enhance Energy Analysis and Diagnostic Centers . . . . . . . 45

(16) Accelerate Source Reduction, Pollution Prevention, and Recycling . . . . . . 46

(17) Improve Efficiency of Fertilizer Nitrogen Use . . . . . . . . . . . . . . . . . 47

(18) Reduce Pesticide Use . . . . . . . . . . . . . . . . . . . 48

Industrial Actions Summary $\ldots \ldots \ldots \ldots \ldots \ldots \ldots \ldots \ldots \ldots \ldots \ldots \ldots$

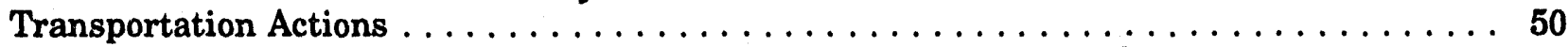

(19) Reform Federal Tax Subsidy for Employer-Provided Parking . . . . . . . . . . 50

(20) Adopt a Transportation System Efficiency Strategy . . . . . . . . . . . 52

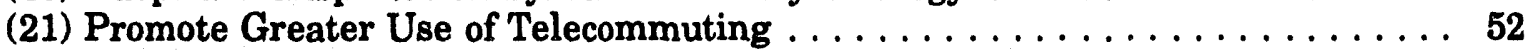

(22) Develop Fuel Economy Labels for Tires $\ldots \ldots \ldots \ldots \ldots \ldots \ldots \ldots \ldots \ldots$

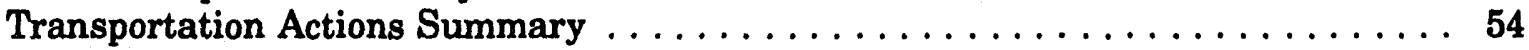

Energy Supply Actions . . . . . . . . . . . . . . . . . . . . . . . . . . . . 54

(23) Increase Natural Gas Share of Energy Use through Federal Regulatory

Reform

(24) Promote Seasonal Gas Use for the Control of Nitrogen Oxides $\left(\mathrm{NO}_{\mathbf{x}}\right)$. . . . . .

(25) Commercialize High-Efficiency Gas Technologies . . . . . . . . . . . . . 56

(26) Form Renewable Energy Market Mobilization Collaborative

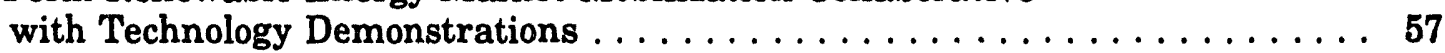

(27) Promote Integrated Resource Planning . . . . . . . . . . . . . . . 57

(28) Retain and Improve Hydroelectric Generation at Existing Dams . . . . . . . . 58

(29) Accelerate the Development of Efficiency Standards for Electric Transformers . 59

(30) Launch Energy Star Transformers . . . . . . . . . . . . . . . . . . . . . 59

(31) Reduce Electric Generation Losses Through Transmission Pricing Reform . . . 59

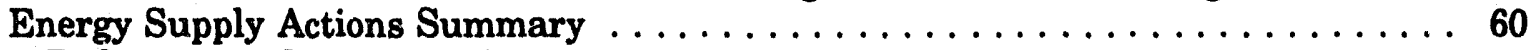

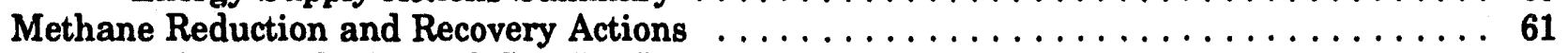

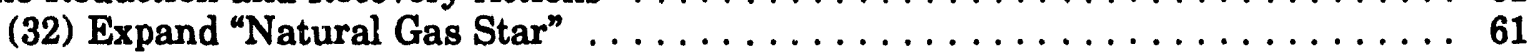

(33) Increase Stringency of Landfill Rules and

(34) Expand Landfill Outreach Program .................... 61

(35) Launch Coalbed Methane Outreach Program . . . . . . . . . . . . . . . . . 62

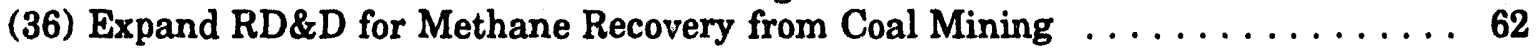

(37) Expand RD\&D for Methane Recovery from Landfills . . . . . . . . . . . . 63

(38) Expand AgStar Partnership Program with Livestock Producers . . . . . . . . . 64

(39) Improve Ruminant Productivity and Product Marketing . . . . . . . . . 64

Methane Reduction and Recovery Actions Summary . . . . . . . . . . . . 65 
Hydrofluorocarbon (HFC), Perfluorocarbon (PFC) and Nitrous Oxide $\left(\mathrm{N}_{2} \mathrm{O}\right)$

Reduction Actions

(40) Narrow Use of Chemicals with High Global Warming Potential (GWP),

Using the Clean Air Act and Production Stewardship to Reduce Emissions . . . 65

(41) Create Partnerships with Manufacturers of HFC-22 to Eliminate HCFC-23 Emissions . . . . . . . . . . . . . . . . . . . 67

(42) Launch Partnership with Aluminum Producers to Reduce Emissions from Manufacturing Processes . . . . . . . . . . . . . . . . . . . . 67

HFC, PFC, and $\mathrm{N}_{2} \mathrm{O}$ Reduction Actions Summary $\ldots \ldots \ldots \ldots \ldots \ldots$

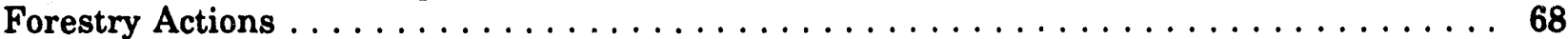

(43) Reduce the Depletion of Nonindustrial Private Forests $\ldots \ldots \ldots \ldots \ldots \ldots$. . . 68

(44) Accelerate Tree Planting in Nonindustrial Private Forests . . . . . . . . . . . 69

Forestry Actions Summary . . . . . . . . . . . . . . . . . . . . 69

IV. Integrated Analysis of Energy-Related Actions $\ldots \ldots \ldots \ldots \ldots \ldots \ldots \ldots \ldots$

Energy Projections: Administration Baseline and Combined Policy Cases . . . . . . . 71

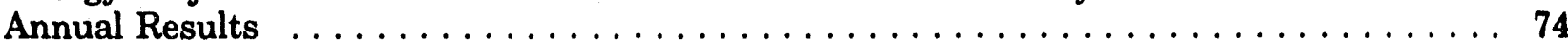

Integration of Demand-Side Actions $\ldots \ldots \ldots \ldots \ldots \ldots \ldots \ldots \ldots \ldots$

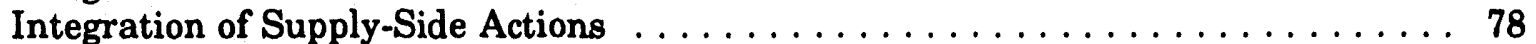

Integration of Demand-Side and Supply-Side Actions $\ldots \ldots \ldots \ldots \ldots \ldots \ldots$

Appendix A. Summary Table from the Climate Change Action Plan . . . . . . . . . . . . 79

Appendix B. Annual Greenhouse Gas Emissions Estimates $\ldots \ldots \ldots \ldots \ldots$

Appendix C. Contacts $\ldots \ldots \ldots \ldots \ldots \ldots \ldots \ldots \ldots \ldots \ldots \ldots \ldots \ldots \ldots$

Appendix D. Condensed Model Report, 1990 and $2000 \ldots \ldots \ldots \ldots \ldots$

Appendix E. An Overview of the IDEAS Model $\ldots \ldots \ldots \ldots \ldots \ldots \ldots \ldots \ldots \ldots$ 
1. Key Criteria for Narrowing the Options List $\ldots \ldots \ldots \ldots \ldots \ldots \ldots \ldots \ldots \ldots \ldots \ldots$

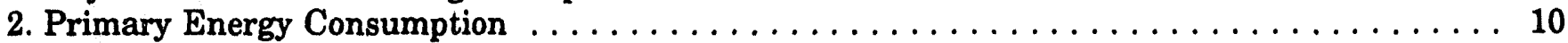

3. Economic Assumptions: Comparison of AEO93 and Administration Baseline Cases . . . . . . 12

4. Transportation Sector: Comparison of Administration Baseline and AEO93 Assumptions . . . 13

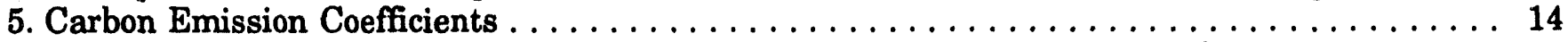

6. Appliance and Air Conditioning Saturation Assumptions for the Residential

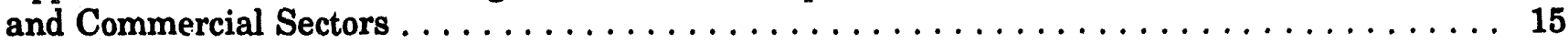

7. Building Stock Lifetime and Discount Rate Assumptions for the Residential and Commercial Sectors $\ldots \ldots \ldots \ldots \ldots \ldots \ldots \ldots \ldots \ldots \ldots \ldots \ldots \ldots \ldots$

8. Industrial Product/Process Change Multipliers $\ldots \ldots \ldots \ldots \ldots \ldots \ldots \ldots \ldots \ldots \ldots \ldots$

9. Stock Lifetime and Capical Charge Rate Assumptions for the Industrial Sector . . . . . . . . 18

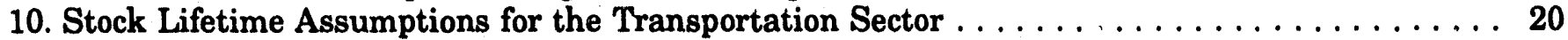

11. Electricity Generation Technologies Represented in the IDEAS Model . . . . . . . . . . . 22

12. Electricity Generation Technology Characteristics in the IDEAS Model, Year $2000 \ldots \ldots \ldots 22$

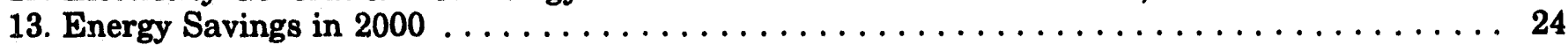

14. Methane Emissions Estimates for the Administration Baseline, 1990-2000 . . . . . . . . 25

15. Nitrous Oxide Emissions Estimates for the Administration Baseline, 1990-2000 . . . . . . . 26

16. HFC and PFC Emissions Estimates for the Administration Baseline, 1990-2000 . . . . . . . 27

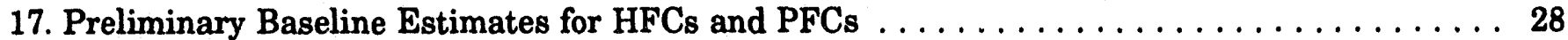

18. Forestry Carbon Sequestration Estimates for the Administration Baseline, 1990-2000 . . . . 31

19. Market Penetration Rates and Energy Saving for Actions (4) and (5), Year 2000 . . . . . . . 35

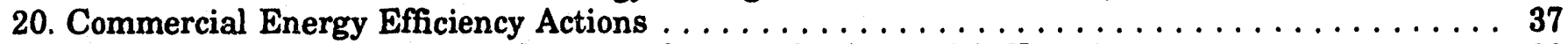

21. Market Penetration Rates and Energy Savings for Action (6), Year $2000 \ldots \ldots \ldots \ldots$

22. Example of Information Contained in an Engineering Cost Curve:

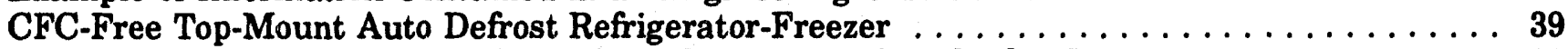

23. Energy Savings from Enhanced Residential Appliance Standards, Year 2000 . . . . . . . . 39

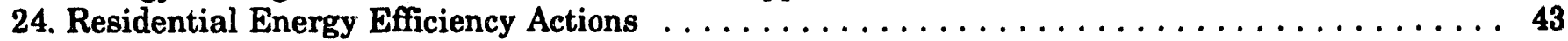

25. Assumptions Used to Model the Motor Challenge, Year $2000 \ldots \ldots \ldots \ldots \ldots \ldots \ldots$

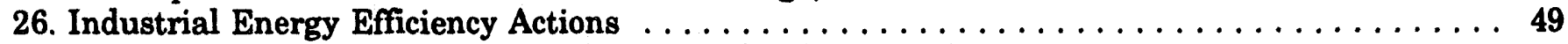

27. Inputs for the Parking Cash-Out Option Under Action (19) $\ldots \ldots \ldots \ldots \ldots \ldots \ldots \ldots \ldots \ldots$

28. Potential Impacts from Telecommuting, Year $2000 \ldots \ldots \ldots \ldots \ldots \ldots \ldots \ldots \ldots$

29. IDEAS Parameter Inputs for Tire Fuel Economy, Year $2000 \ldots \ldots \ldots \ldots \ldots \ldots \ldots$

30. Transportation Energy Efficiency Actions $\ldots \ldots \ldots \ldots \ldots \ldots \ldots \ldots \ldots \ldots \ldots \ldots \ldots$

31. IDEAS Parameter Adjustments for Natural Gas Regulatory Initiatives, Year $2000 \ldots \ldots$. . . 55

32. IDEAS Technology Assumptions for Action (26), Year $2000 \ldots \ldots \ldots \ldots \ldots \ldots \ldots$

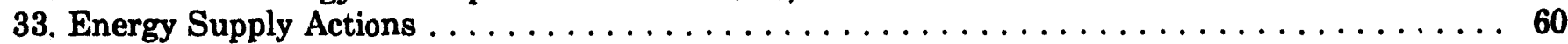

34. Methane Recovery and Reduction Actions $\ldots \ldots \ldots \ldots \ldots \ldots \ldots \ldots \ldots \ldots \ldots \ldots \ldots \ldots \ldots \ldots$

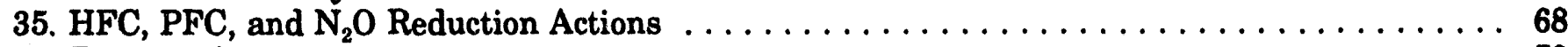

36. Forestry Actions $\ldots \ldots \ldots \ldots \ldots \ldots \ldots \ldots \ldots \ldots \ldots \ldots \ldots \ldots \ldots \ldots \ldots \ldots$

37. Primary Energy Consumption and Carbon Emissions in the Combined Policy Case, 1990-2000 


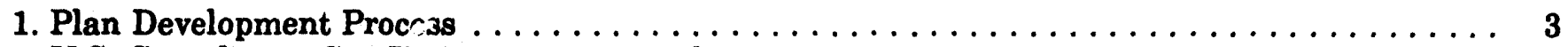

2. U.S. Greenhouse Gas Jimissions, 1990 and $2000 \ldots \ldots \ldots \ldots \ldots \ldots \ldots \ldots \ldots \ldots$

3. Annual U.S. Greenhouse Gas Emissions in the Combined Policy Case, 1995-2000 . . . . . . 7

4. U.S. Net Carbon Emissions, $2000 \ldots \ldots \ldots \ldots \ldots \ldots \ldots \ldots \ldots \ldots \ldots \ldots \ldots$

5. U.S. Carbon Emissions by Sector, $2000 \ldots \ldots \ldots \ldots \ldots \ldots \ldots \ldots \ldots \ldots \ldots \ldots \ldots$

6. U.S. Carbon Emissions by Fuel, $2000 \ldots \ldots \ldots \ldots \ldots \ldots \ldots \ldots \ldots \ldots \ldots \ldots \ldots \ldots$

7. U.S. Primary Energy Consumption by Sector, $2000 \ldots \ldots \ldots \ldots \ldots \ldots \ldots \ldots \ldots \ldots$

8. Conservation Cost-Savings Curve, Residential-Refrigeration $\ldots \ldots \ldots \ldots \ldots \ldots \ldots \ldots \ldots$

9. Conservation Cost-Savings Curve, Conımercial-Electric Space Heating . . . . . . . . . . 17

10. Conservation Cost-Savings Curve, Industrial-Machine Drive/Electrolytic . . . . . . . . . 19

11. Conservation Cost-Savings Curve, Transportation-Large Autos, $2000 \ldots \ldots \ldots \ldots \ldots$

12. Primary Energy Consumption, 1990 and $2000 \ldots \ldots \ldots \ldots \ldots \ldots \ldots \ldots \ldots \ldots \ldots \ldots$

13. Delivered Energy Consumption, 1990 and $2000 \ldots \ldots \ldots \ldots \ldots \ldots \ldots \ldots \ldots \ldots \ldots$

14. Increase in Primary Energy Consumption, $1990-2000 \ldots \ldots \ldots \ldots \ldots \ldots \ldots \ldots$

15. Utility Energy Consumption, 1990 and $2000 \ldots \ldots \ldots \ldots \ldots \ldots \ldots \ldots \ldots \ldots \ldots \ldots$

16. Change in Annual Carbon Emissions by Sector, $1990-2000 \ldots \ldots \ldots \ldots \ldots \ldots \ldots \ldots$

17. Change in Annual Carbon Emissions by Fuel, $1990-2000 \ldots \ldots \ldots \ldots \ldots \ldots \ldots \ldots \ldots$

18. Total Investment in the Energy Sector Due to Plan Actions, Combined Policy Case, 


\section{Origins and Context of the Climate Change Action Plan}

In June 1992, heads of state and citizens from more than 160 countries met at the United Nations Conference on Environment and Development (UNCED) in Rio de Janeiro, Brazil, to address the globalscale linkages between environmental concerns and development needs. This "Earth Summit" launched several ambitious initiatives to address global environmental threats. The United States joined with 161 countries in signing the Framework Convention on Climate Change (FCCC), an agreement to address the danger of global climate change.

The ultimate objective of the FCCC is to:

". . . achieve ... stabilization of greenhouse gas concentration in the atmosphere at a level that would prevent dangerous anthropogenic interference with the climate system" (Article 2, FCCC).

While the FCCC includes no internationally binding obligations to reduce anthropogenic emissions of greenhouse gases that have contributed to the recent rising trend in atmospheric concentrations to any specified level in any set year, developed country signatories and other Annex I parties are committed to:

“. . adopt national policies and take corresponding measures on the mitigation of climate change, by limiting its anthropogenic emissions of greenhouse gases and protecting and enhancing its greenhouse gas sinks and reservoirs. These policies and measures will demonstrate that the developed countries are taking the lead in modifying longer-term trends in anthropogenic emissions consistent with the objective of the Convention, recognizing that the return by the end of the present decade to earlier levels of anthropogenic emissions of carbon dioxide and other greenhouse gases not controlled by the Montreal Protocol would contribute to such modification . . ." (Article 4, Paragraph 2(a), FCCC).

On Earth Day 1993, President Clinton announced that the United States would take a leadership role in moving to address the threat of climate change:

Today, I reaffirm my personal and announce our nation's commitment to reducing our emissions of greenhouse gases to their 1990 levels by the year 2000. I am instructing my administration to produce a cost-effective plan . . . that can continue the trend of reduced emissions. This must be a clarion call, not for more bureaucracy or regulation or unnecessary cost, but instead for American ingenuity and creativity, to produce the best and most energy-efficient technology.

The Climate Change Action Plan documented in this Annex provides a roadmap by which the United States can meet the greenhouse gas reduction commitment set by the President. It will also serve as the basis for the greenhouse gas mitigation strategy that will be included as a part of the National Action Plan that the United States will submit to the international community in the fall of 1994, pursuant to provisions of the FCCC. ${ }^{3}$

This Annex is organized as follows. This chapter provides a context for and description of the Plan development process. Chapter 2 reviews the baseline used in Plan development, with emphasis on the energy sector. Chapter 3 provides an action-by-action description of the analysis, with year-by-year detail to supplement the information included in the October 1993 Plan document. Chapter 4 presents the results of the integrated analysis of energy sector actions, including a year-by-year profile of emissions reductions in the Plan scenario.

3. The Convention, which the United States was the first industrialized country to ratify, achieved the 50 th ratification on December 21, 1993. The Convention enters into force 3 months after the 50th ratification. National Action Plans are to be submitted 6 months after entry into force. 
Appendices include: the summary table (with minor corrections) published in the Climate Change Action Plan, which outlines the projected financial impact and the potential for reducing greenhouse gas emissions for each action (Appendix A); a year-by-year summary table of estimated greenhouse gas emissions under the Plan (Appendix B); a list of U.S. Government contacts for individual Plan actions (Appendix C); condensed reports of IDEAS outputs for 1990 and 2000 (Appendix D); and a brief overview of the IDEAS model used for the integrated analysis of energy actions (Appendix E).

\section{The Plan Development Process}

Following his Earth Day address, the President directed the White House Office on Environmental Policy (OEP) to coordinate interagency and public input to the development of a plan to achieve the objective of reducing the aggregate of U.S. emissions of greenhouse gases to its 1990 level by the year 2000 .

\section{Approach}

\section{Maximizing Public Particlpation}

Wide public participation serves two key purposes. First, it provides a means to draw on the ingenuity and creativity of the American people to consider the most comprehensive range of options possible in all emission-producing sectors of the economy, as called for by the President. Second, it helps to assure that the private-sector interests that would ultimately be called upon to limit their greenhouse gas emissions or increase sequestration of greenhouse gases would see implementation of the Plan as a partnership opportunity rather than as a regulatory threat.

The White House Conference on Global Climate Change, held in Washington, DC, on June 10-11, 1993, was the starting point for incorporating public participation into the Plan development process. The conference was designed to provide for an exchange of ideas between Federal agencies, industry stakeholders, State and local interests, environmental groups, and anyone else with an interest in global climate change. The level of interest in this issue was reflected by the attendance of more than 800 people at the two-day workshop, which had initially been planned for only 300 participants.

At the opening plenary session of the conference, participants were challenged to work together in accomplishing the President's goals. Creativity, teamwork, and innovation were repeatedly mentioned by the speakers, which included Secretary of Energy Hazel O'Leary, OEP Director Kathleen McGinty, and the State Department's Counsellor Tim Wirth. Other speakers provided brief discussions of technical issues, including recent scientific findings on climate change, the magnitude of the emissions reduction needed to achieve the President's goals, and a description of the IDEAS energy modeling framework.

Following the plenary session, the participants divided into 10 workshop groups. These groups addressed emissions reduction opportunities in the following areas: Energy Supply, Energy Demand (residential, commercial, and industrial), Transportation (auto/light truck, commercial, infrastructure), Methane and Other Gases, Sinks, and Joint Implementation. Participants in the workshops identified and discussed specific options, many of which were ultimately included in the plan. Continuing contacts with privatesector experts on "live" options were maintained throughout the Plan development process.

The Plan, ultimately issued in October 1993, is based on the best ideas offered throughout this process. The inclusion of recycling and other initiatives favored by environmental groups and the highly favorable response of the private sector to the voluntary initiatives included in the Plan-such as the industrialsector Motor Challenge, the utility-sector Climate Challenge, and the expanded Green Lights programdemonstrate the advantages of government working in close cooperation with the public to produce a plan that will meet our environmental objectives while strengthening the economy. 


\section{A Broad Interagency Team}

Soon after the President's Earth Day address, OEP initiated a set of interagency working groups to consider mitigation opportunities within broad sectors of the economy and to solicit public participation in the Plan development process. The Climate Change Mitigation Group (CCMG), consisting primarily of appointees at the Assistant Secretary level or above, was established to serve as the executive board for the Plan development process. This group was primarily responsible for shaping the content of the Action Plan.

The Plan encompasses three major groupings of actions: energy actions to reduce carbon dioxide emissions from fossil fuel combustion, actions to reduce emissions of other gases (methane, nitrous oxides, hydrofluorocarbons, and perfluorocarbons), and actions to increase carbon sequestration in the terrestrial biosphere. Each component had its own integrated modeling framework. Integrated analysis of energysector actions was accomplished using the IDEAS model supported by the Policy Office of the U.S. Department of Energy (DOE). Evaluation of actions for gases other than carbon dioxide relied on models supported by the U.S. Environmental Protection Agency (EPA). Carbon sequestration activities were examined using models maintained by the U.S. Department of Agriculture (USDA).

Figure 1 details the basic structure of the interagency process.

Figure 1. Plan Development Process

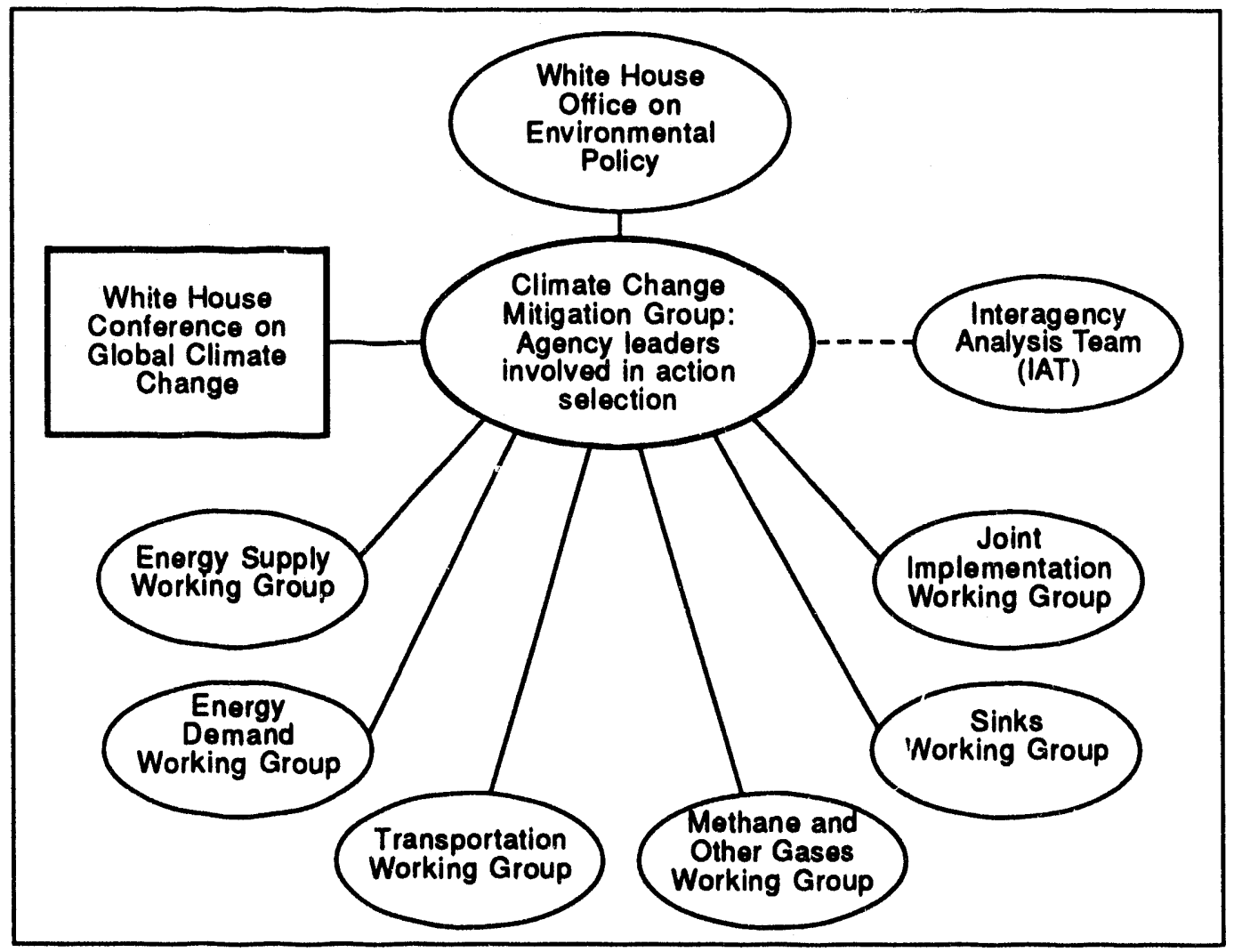

\section{Narrowing the Options List}

Ideas for emissions reduction evolved from internal work, presentations and discussions at the White House Conference on Global Climate Change, and from other outside sources, such as environmental organizations, contractors, and industry leaders. By early July, OEP had assembled a list of 247 options, 146 of which included detailed program descriptions, covering a wide range of possible greenhouse gas 
reduction measures. In some cases, several options outlined similar or overlapping ideas. Each emissions reduction idea was outlined in a short description containing quantitative and qualitative information on key yardsticks, including the expected amount of emission reduction, cost-effectiveness, and administrative or legislative requirements for implementation.

In order to focus on options showing the most promise, the CCMG made a "first cut" based on criteria such as the size of the near-term reduction in greenhouse gases, cost-effectiveness, long-term potential, and ease/speed of implementation. Table 1 provides a description of some key criteria suggested by the CCMG.

Table 1. Key Criterla for Narrowing the Optlons Llst

\begin{tabular}{|c|c|}
\hline Key Criterion & Description \\
\hline Greenhouse Gas Reduction & $\begin{array}{l}\text { An option had to provide a quantifiable reduction in net greenhouse gas emissions } \\
\text { through scientifically valid data and methodologies. }\end{array}$ \\
\hline Cost-Effectiveness & $\begin{array}{l}\text { This criterion was quantified as the ratio of the reduction, in million metric tons } \\
\text { carbon equivalent (MMTce), to the cost of putting the action into effect (on both an } \\
\text { annual and total basis). Actions that impose no or low costs per ton of emissions } \\
\text { reduction are preferred. }\end{array}$ \\
\hline Near-Term Impact & $\begin{array}{l}\text { The immediate goal is to return net greenhouse gas emissions to } 1990 \text { levels by } \\
2000 \text {. Given unavoidable lags in program implementation, the window for programs } \\
\text { to affect emissions is short. Actions with short startup times and quick results are } \\
\text { generally preferred. }\end{array}$ \\
\hline Long-Term Impact & $\begin{array}{l}\text { The global warming issue will not be solved in the next } 6 \text { years, so the actions need } \\
\text { to provide long-term emissions reductions as well. Actions that combine a modest } \\
\text { near-term contribution to emissions reduction with a major contribution after the turn } \\
\text { of the century can be attractive. }\end{array}$ \\
\hline Ease/Speed of Implementation & $\begin{array}{l}\text { This is a very important issue for a "fast start" to the Climate Change Action Plan. } \\
\text { The potential for protracted regulatory and legislative disputes is a negative factor. } \\
\text { Use of existing legislation/authority, such as the Energy Policy Act of } 1992 \text { (EPACT) } \\
\text { and the Clean Air Act, and the expansion, adaptation, and reinforcement of } \\
\text { voluntary programs to promote government-private partnerships, can help avoid } \\
\text { unnecessary delays. }\end{array}$ \\
\hline
\end{tabular}

Using the criteria listed in Table 1, the CCMG narrowed the list of actions under active consideration to approximately 50 . Based on information provided by their proponents, and prepared in accordance with interagency guidance, these actions were judged to have the potential to achieve the President's emissions reduction objective. The significant reduction in the number of "live" options allowed for more in-depth analysis of actions judged as likely candidates for inclusion in the Plan.

The lineup of actions was reviewed many times before the Plan was finalized. Evaluations focused on the feasibility of actions, their estimated impacts, or the magnitude of the estimated gap between baseline and target emissions.

\section{Interagency Analysis}

Interagency analysis was a key part of this process. The degree of cooperation and coordinated activity at the cabinet, subcabinet, and staff levels was unprecedented. The analysis presented in the Plan reflects a consensus view, rather than the perspective of the analysts within any single agency or organization.

The Interagency Analysis Team (IAT), a subsidiary group of the CCMG, was established and charged with evaluating and coordinating analyses of proposed actions put forward by individual agencies and 
outside proponents. At the initial stages of the process, the IAT provided guidelines for the consistent presentation of option information, so that all descriptions would report key criteria values using the same conventions (such as discount rates and dollars of the same years). Staff at the various agencies were responsible for providing the initial program descriptions and all the information required to support the narrowing of the options list by the CCMG. The team also reviewed the content of the standalone analyses prepared by proponents of individual options.

After the CCMG narrowed the set of options under consideration, the actions remaining were subjected to a more thorough critique, and an integrated analysis of related options was developed. To facilitate this effort, the authors of the options provided the IAT with the necessary parameters to integrate the options.

Whenever the action list was adjusted, modeling analysis was repeated to account for potential overlap and synergistic impacts with other actions. The new emissions reduction estimates were then presented and evaluated relative io the President's goal of cost-effectively returning greenhouse gas emissions to 1990 levels by the year 2000. If at any point the analysis showed a shortfall in meeting the goals of the Administration, additional options, either drawn from the original list or newly developed, were added to make the Plan consistent with the President's goal.

\section{Integrated Modeling of Energy Sector Actions}

Most energy policy options affect more than one sector or fuel; for example, changes in one sector often affect fuel prices, which in turn affect energy demand and supply in other sectors. In addition, policy options usually do not work in isolation from other options; some options work in tandem, while others have overlapping impacts. Interactions among energy prices, supply, demand, and policies must be considered to generate the best possible estimates of overall energy and emissions impacts.

For example, if a proposed policy promoted the use of natural gas in industry, either by reducing the effective price of natural gas or by increasing the effective price of competing fuels for industrial buyers, consumers within other sectors would clearly be affected by the price changes, since the prices for fuels at the source would change to compensate for the changes in supply and demand for industrial fuels. Hence, it would be inappropriate to assume that the effects of a policy implemented within a given sector. could contain the effects of the action within that sector alone. Thus, an integrated modeling approach is necessary.

Policies themselves may also interact. For example, the energy conservation impact of policies to reduce heating and cooling energy consumption by promoting both higher levels of insulation and more energyefficient space conditioning equipment would be less than the sum of their individual effects. In other circumstances, positive synergies, in which the impact of a suite of policies exceeds the sum of their individual effects, are also possible.

\section{Baseline and Policy Scenarios}

Two modeling scenarios, the Administration Baseline and the Combined Policy Case, were constructed to evaluate the actions that were considered as part of the Plan. The Administration Baseline was the business-as-usual scenario from which the potential effects of all the other actions contained in the Plan were measured. The Administration Baseline was defined to reflect expectations of private and public sector behavior, based on all legislation already in effect and all Federal programs as funded as of the date of issuance of the Plan. The Combined Policy Case added to the Administration Baseline the effects of the emissions reduction actions included in the Plan. 


\section{Analysis Results}

\section{Greenhouse Gas Emissions}

Total greenhouse gas (GHG) emissions in the year 1990, measured on a carbon equivalent basis, were estimated to be 1,462 million metric tons carbon equivalent (MMTce). For carbon dioxide, the carbon equivalent was directly obtained as 12/44ths (the carbon fraction of total mass in each carbon dioxide molecule) of the mass of carbon dioxide. For other gases, carbon dioxide equivalents were first calculated using 100-year Global Warming Potentials (GWPs) based on the 1990 Intergovernmental Panel on Climate Change (IPCC) Scientific Assessment ${ }^{4}$ and the 1992 IPCC Supplementary Report. ${ }^{6}$ The carbon equivalent is $12 / 44$ ths of the carbon dioxide equivalent. To simplify the exposition, the term "carbon emissions" is used to mean the carbon equivalent of carbon dioxide emissions throughout this Annex. The total emissions estimate reported above includes emissions of carbon dioxide, net of sinks $\left(\mathrm{CO}_{2}\right)$, methane $\left(\mathrm{CH}_{4}\right)$, nitrous oxide $\left(\mathrm{N}_{2} \mathrm{O}\right)$, and hydrofluorocarbons (HFCs) and perfluorocarbons (PFCs). Estimates of gross carbon emissions in 1990 were based on work produced by the Energy Information Administration (EIA) and published in Emissions of Greenhouse Gases in the United States 1985-1990 (DOE/EIA-0573). Net carbon emissions were derived by subtracting estimates of carbon sinks provided by the USDA from gross carbon emissions. Emissions estimates for methane, $\mathrm{N}_{2} \mathrm{O}$, and HFCs were provided by the EPA.

In the Administration Baseline scenario, U.S. total GHG emissions are expected to increase to 1,568 MMTce in the year 2000 (Figure 2). This total increase reflects rising emissions of carbon and HFCs. Emissions of methane and $\mathrm{N}_{2} \mathrm{O}$ decrease slightly, even in the Baseline scenario.

The Plan reduces projected emissions of all gases in 2000 from their projected Administration Baseline levels. Projected net emissions of carbon, methane, nitrous oxide, and HFCs are reduced by 76 MMT, 16 MMTce, 5 MMTce, and 12 MMTce, respectively. In total, the Plan is projected to return U.S. emissions of greenhouse gases in the year 2000 to their 1990 level, even though net carbon emissions are projected to increase by 24 MMT over that period. Reductions in other gases below their 1990 emissions levels more than offset this increase.

Annual greenhouse gas emissions in the Combined Policy Case peak in 1997 before returning to their 1990 level in the year 2000 (Figure 3). This annual pattern primarily reflects the timing of EPA's landfill rule, included in the Administration Baseline, which sharply reduces methane emissions beginning in 1998. To a lesser extent, it also reflects the lags inherent in Plan actions that spur private investment in emissions-reducing activities.

As noted above, the Plan tracks net rather than gross carbon emissions. In 1990, gross carbon emissions were estimated at 1,367 MMT, and sinks were estimated to sequester $130 \mathrm{MMT}$ of carbon, resulting in net carbon emissions of 1,237 MMT (Figure 4). In the Administration Baseline, net carbon emissions grow to $1,337 \mathrm{MMT}(1,474 \mathrm{MMT}$ gross emissions less $137 \mathrm{MMT}$ annual sequestration) in 2000. The reduction in carbon emissions due to the Plan (66 MMT in gross emissions reduction plus a 10-MMT increase in annual sequestration) results in projected net carbon emissions of 1,261 MMT in 2000 and projected gross carbon emissions of 1,408 MMT in the Combined Policy Case.

The growth rate of carbon emissions differs across sectors in both the Administration Baseline and Combined Policy cases. For the Administration Baseline, growth in carbon emissions over the 1990 to 2000 period for the residential, commercial, industrial, and transportation sectors is 7.5 percent, -1.9 percent, 4.9 percent, and 16.2 percent, respectively (Figure 5). In the Combined Policy Case, carbon emissions growth in all sectors is reduced; for the commercial and industrial sectors, emissions are below their 1990 levels in 2000. The emissions from electric utilities were allocated to the end-use sectors in proportion to their purchases of electricity.

4. Intergovernmental Panel on Climate Change, Climate Change: The IPCC Scientific Assessment (Cambridge University Press, 1990).

5. Intergovernmental Panel on Climate Change, Climate Change 1992: The Supplementary Report to the IPCC Assessment (Cambridge University Press, 1992). 
Figure 2. U.S. Greenhouse Gas Emissions, 1990 and 2000

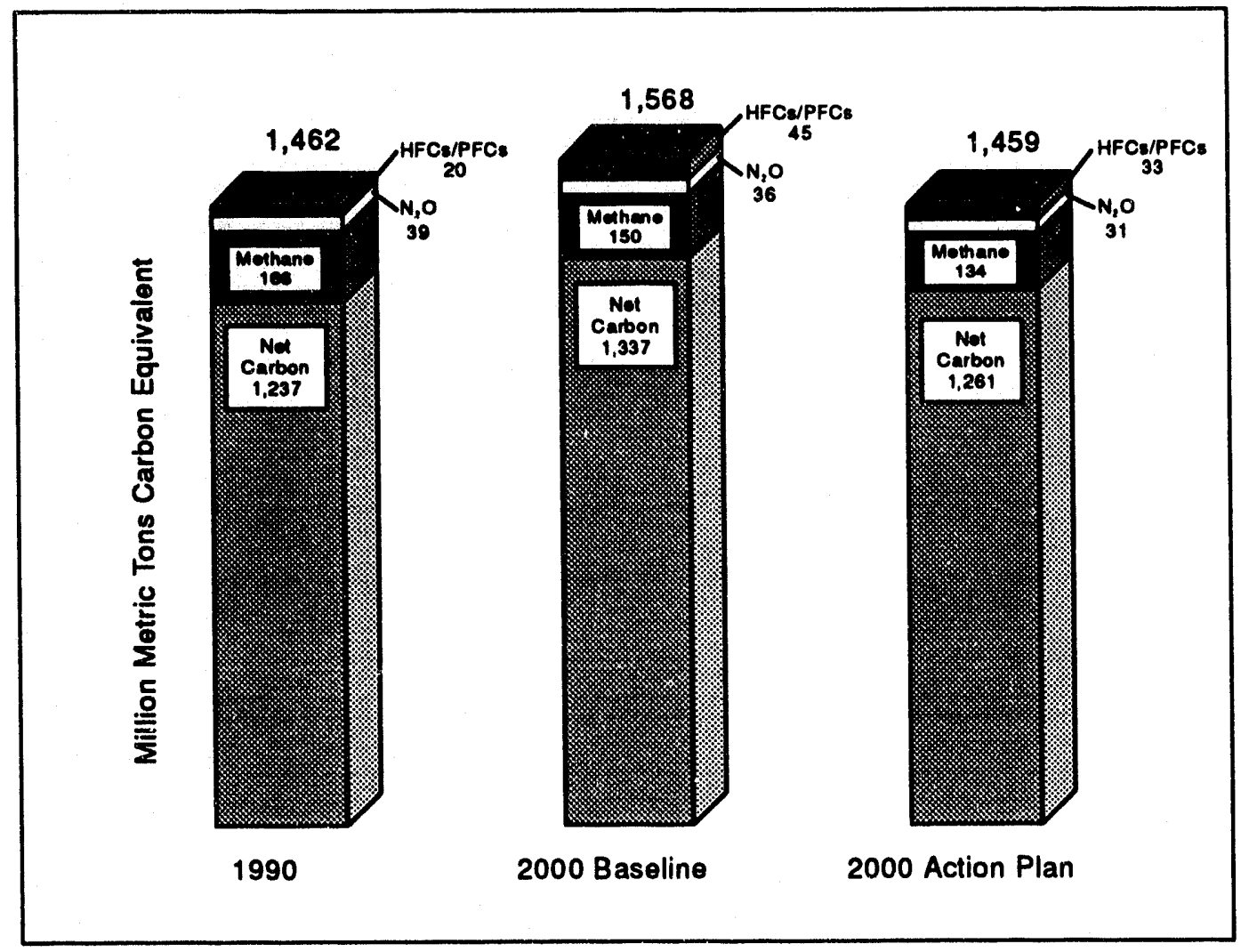

Figure 3. Annual U.S. Greenhouse Gas Emissions In the Combined Pollcy Case, 1995-2000

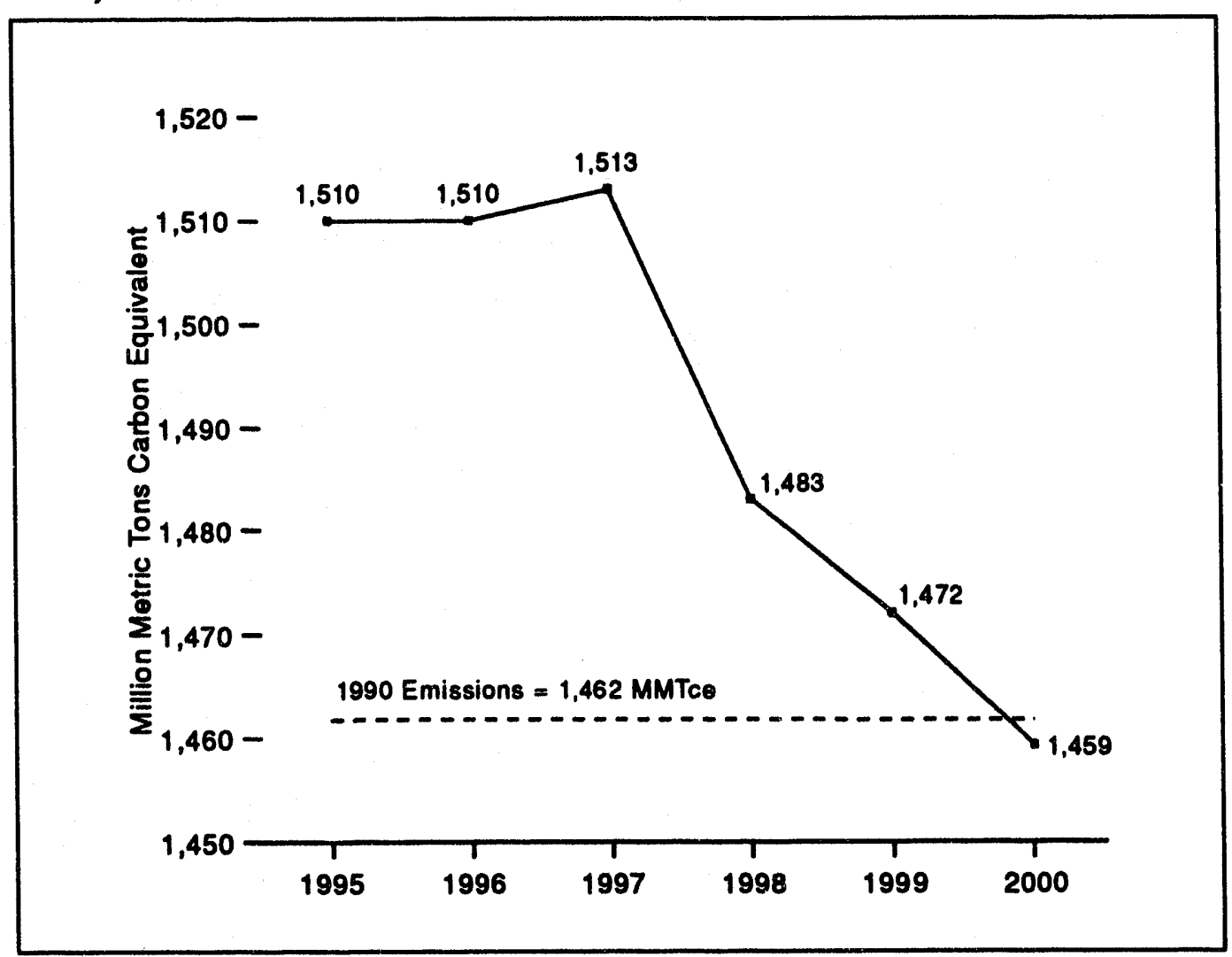


Flgure 4. U.S. Net Carbon Emlssions, 2000

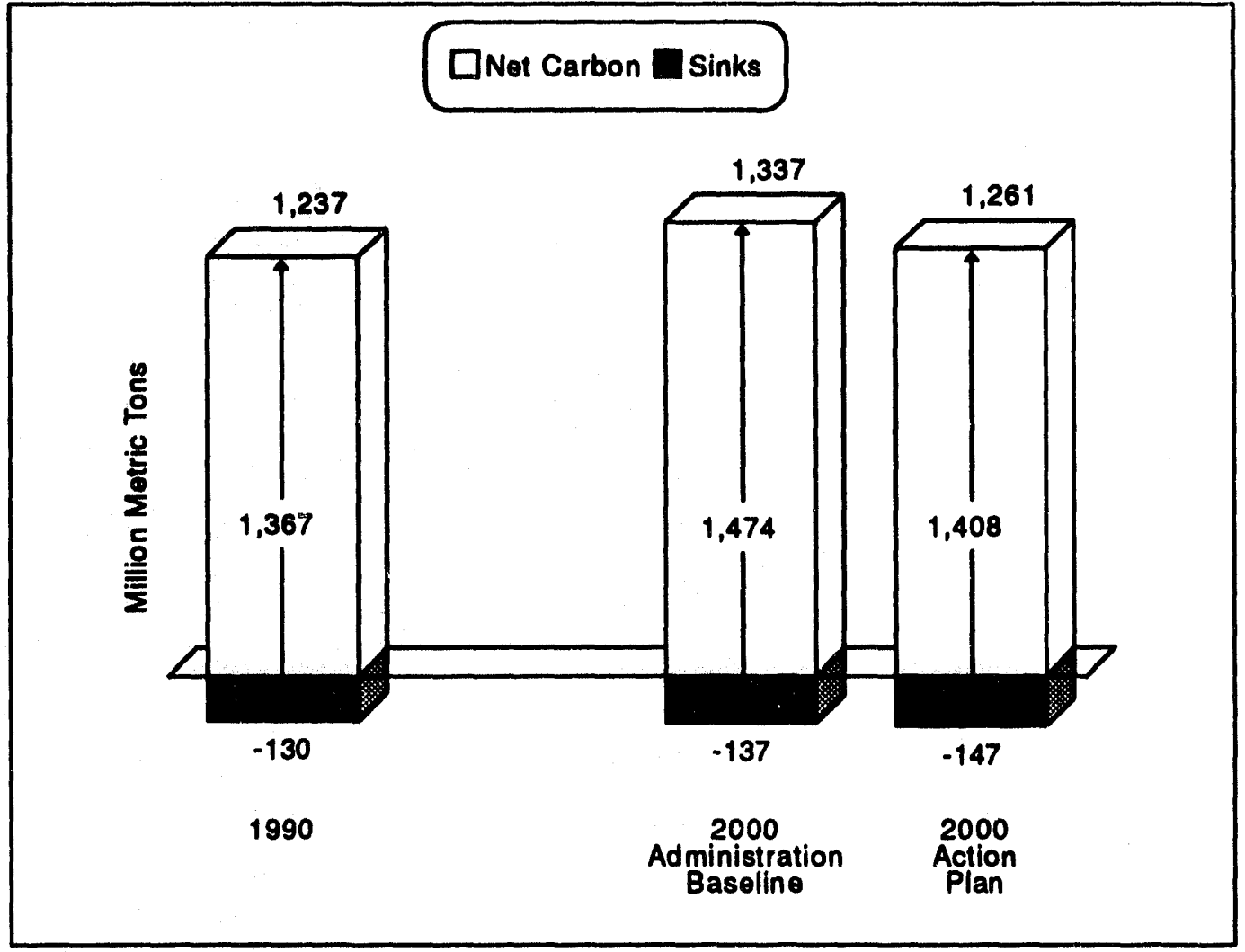

Figure 5. U.S. Carbon Emisslons by Sector, 2000

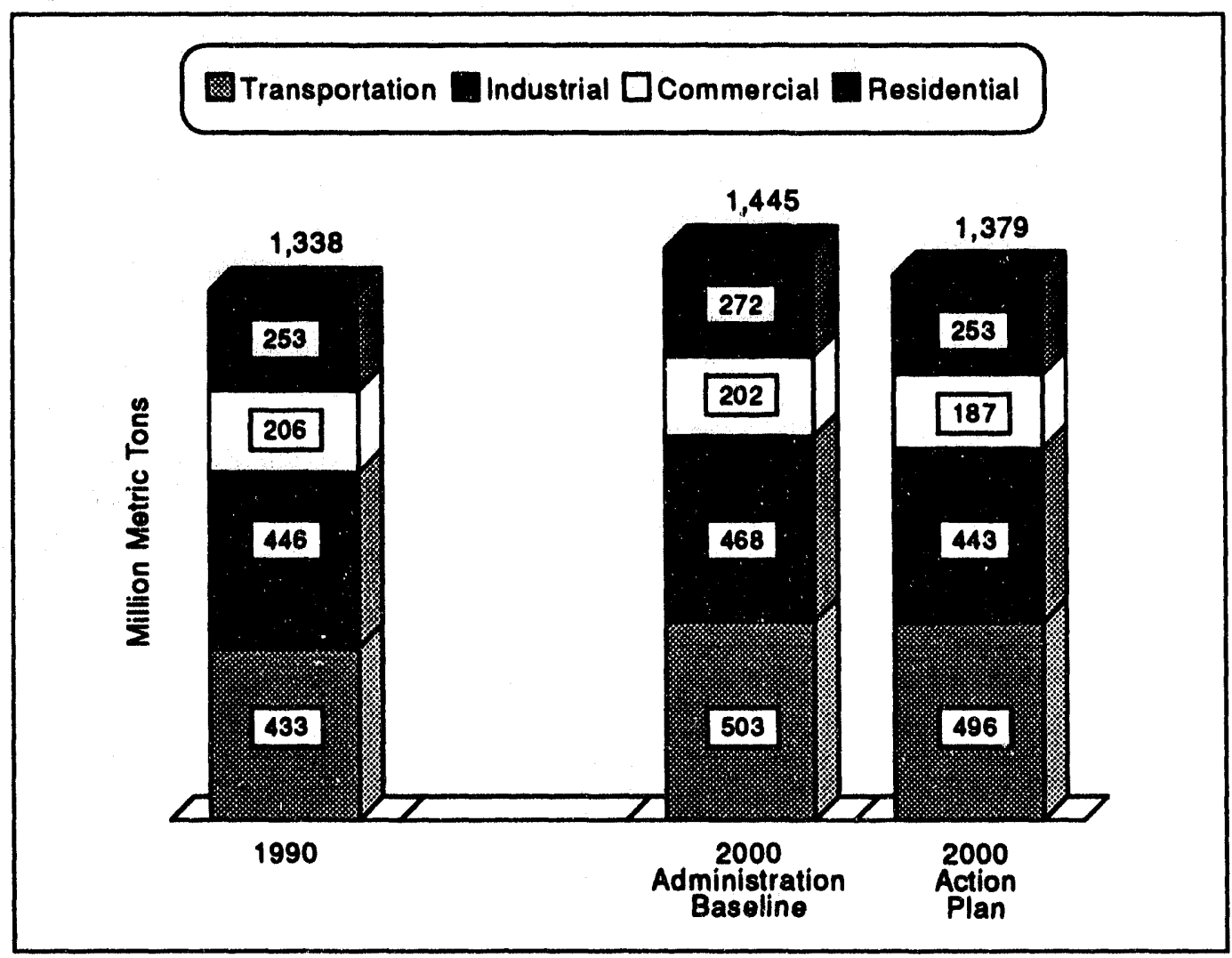

Note: Excludes carbon sequestered through nonfuel use of energy. 


\section{Energy Consumption and Production}

Projected levels of carbon emissions are closely tied to energy consumption because most primary fuel consumption is based on carbon-emitting fossil fuels. Growth in sectoral carbon emissions closely follows the pattern of growth in sectoral energy consumption (Figure 6); growth rates for emissions are slightly lower than energy growth rates due to the increasing share of low- or no-carbon fuels, such as natural gas and renewables. Policies that remove barriers to substitution toward cleaner fuels are one type of cost-effective action to reduce carbon emissions.

Figure 6. U.S. Carbon Emlssions by Fuel, 2000

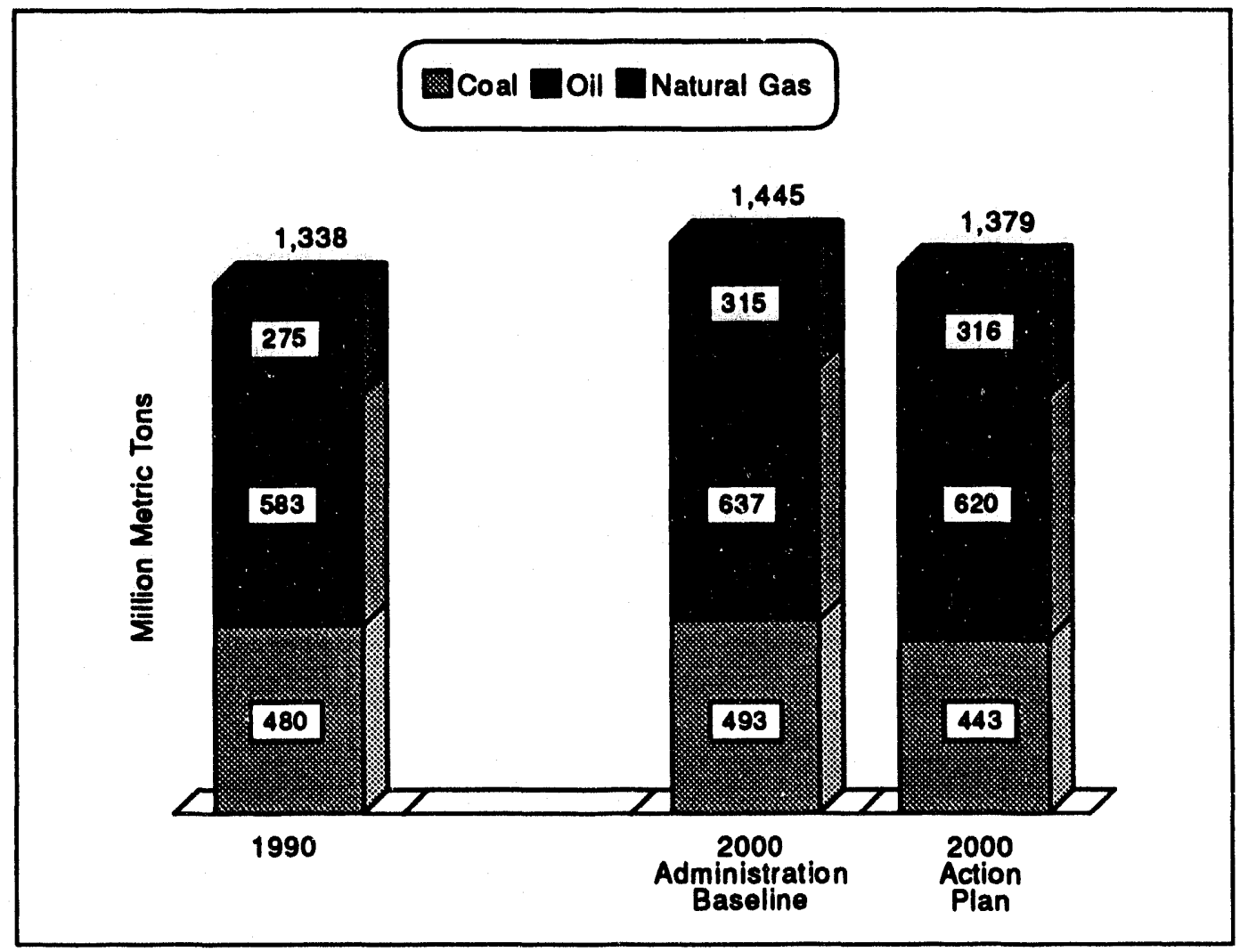

Note: Excludes carbon sequestered through nonfuel use of energy.

Primary energy consumption in 1990 was 84.8 quadrillion British thermal units (Btu) (Table 2). Energy consumption is projected to grow in both the Administration Baseline and Combined Policy cases. In the year 2000, consumption is projected to grow to 94.1 quadrillion Btu in the Administration Baseline and to 91.4 quadrillion Btu in the Combined Policy Case (Figure 7). Energy consumption grows across all sectors in the Administration Baseline. Between 1990 and 2000, primary energy consumption in the Administration Baseline is projected to grow by 13 percent in the residential sector, 14 percent in the transportation sector, and 12 percent in the industrial sector. In the Combined Policy Case, energy growth moderates somewhat as more energy-efficient devices substitute for less efficient ones. The Combined Policy Case cuts energy consumption growth over the 1990 to 2000 period by 4 percentage points in the residential sector, by slightly less than 3 percentage points in the industrial sector, and by 2 percentage points in the transportation sector. Commercial sector energy consumption in 2000 is lower than its 1990 level in the Combined Policy Case. 
The Climate Change Action Plan: Technical Supplement

Table 2. Primary Energy Consumption (Quadrillion Btu)

\begin{tabular}{|l|c|c|c||}
\hline \multicolumn{1}{|c|}{ Soctor } & 1990 & $\begin{array}{c}2000 \\
\text { Administration Baseline }\end{array}$ & $\begin{array}{c}2000 \\
\text { Combined Policy Case }\end{array}$ \\
\hline Residential & 16.9 & 19.1 & 18.3 \\
\hline Commercial & 13.2 & 13.2 & 12.7 \\
\hline Industrial & 32.1 & 35.8 & 34.8 \\
\hline Transportation & 22.6 & 26.0 & 25.6 \\
\hline Total & 84.8 & 94.1 & 91.4 \\
\hline
\end{tabular}

Figure 7. U.S. Primary Energy Consumption by Sector, 2000

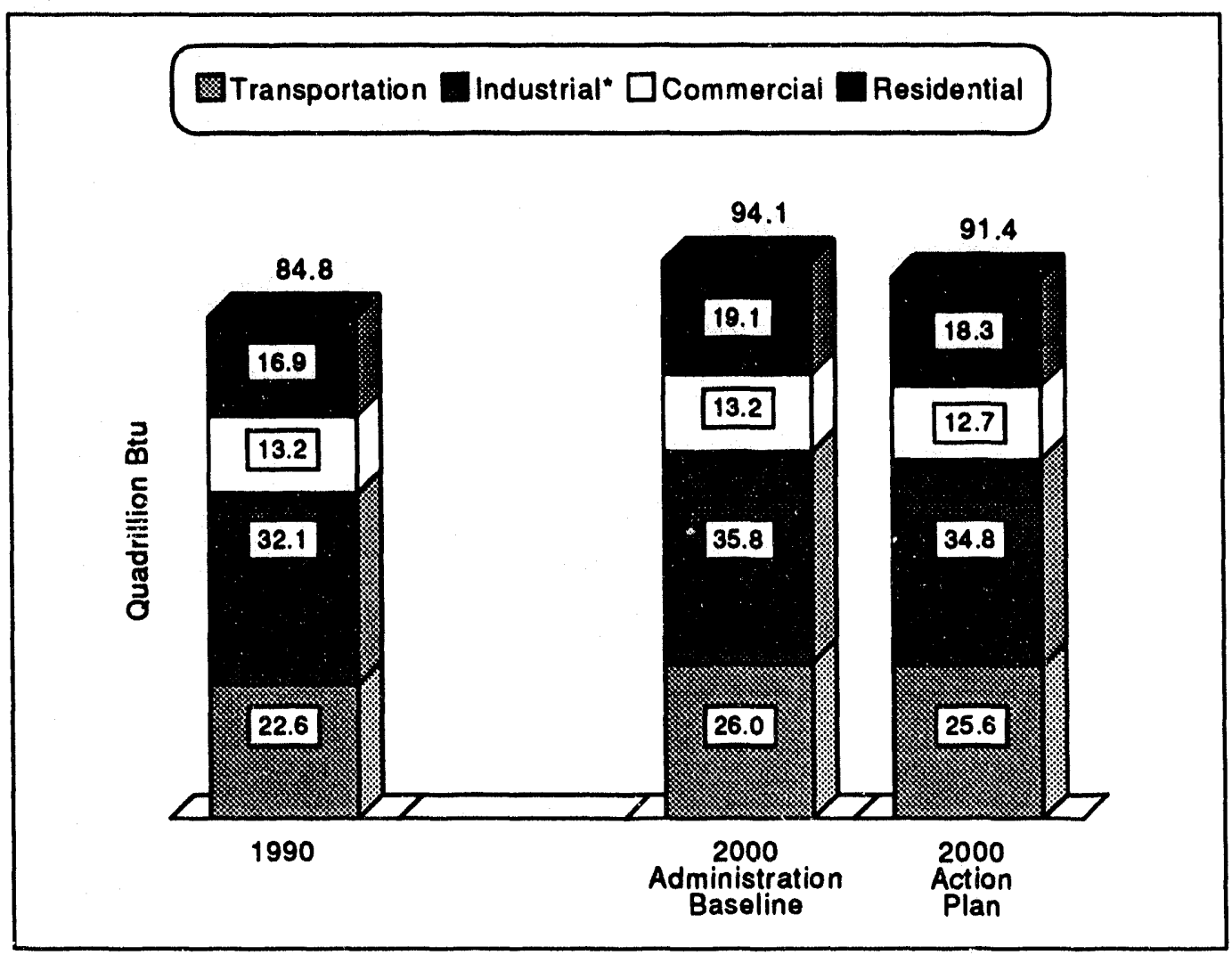

"Includes fuel used for non-energy feedstocks. 


\section{Development of the Administration Baseline}

As noted in Chapter 1, the Plan includes actions that reduce emissions of carbon, methane, nitrous oxide $\left(\mathrm{N}_{2} \mathrm{O}\right)$, hydrofluorocarbons ( $\mathrm{HFCs}$ ), and perfluorocarbons (PFCs), as well as actions to increase annual carbon sequestration in the terrestrial biosphere. This section begins with an extended discussion of the scenarios for the energy sector, which is the preponderant source of carbon emissions. Brief discussions of the scenarios for other gases follow.

\section{The Administration Baseline Scenario for Energy}

The Administration Baseline for energy was derived from the Energy Information Administration's (EIA's) Annual Energy Outlook 1993 (AEO93) Reference Case. The EIA is an independent statistical agency within the U.S. Department of Energy (DOE), and its Reference Case is widely considered a neutral starting point for analysis. In addition, the assumptions used in the AEO93 Reference Case are well-documented in a published Appendix. ${ }^{6}$ EIA uses a rigorous review program, supported by its Office of Statistical Standards, to safeguard the approach and assumptions used in its projections.

The initial step in developing the Administration Baseline was to calibrate the Integrated Dynamic Energy Analysis Simulation (IDEAS) model to the AEO93 Reference Case. Two types of additional adjustments were then made to provide a credible forecast based on up-to-date information and Administration economic and policy assumptions. First, some of the macroeconomic and other assumptions used in the AEO93 were updated as new and better information became available. Second, the impacts of existing Federal programs, such as the U.S. Environmental Protection Agency (EPA) Green Lights program and DOE research and development (R\&D) activities being pursued under the Energy Policy Act of 1992 (EPACT) were included. Because the models used to support the AEO93 are statistically derived, they often do not reflect the impact of R\&D programs or voluntary programs to increase market penetration of cost-effective energy-efficient technologies.

The next section of this chapter outlines differences in economic and technology assumptions from those used by EIA. The second section details some of the key modeling assumptions used for the Administration Baseline. The third second describes current policies affecting carbon emissions not in the AE093 Reference Case that were included in the Administration Baseline.

\section{Economic and Technology Assumptions for the Energy Sector}

\section{Economic Assumptions}

\section{Rate of Economic Growth}

Economic growth projections used in developing the Administration Baseline reflect the most current estimate from the Council of Economic Advisers (CEA) at the time of the Plan's release. These growth rates differ only slightly from those used by EIA in the AEO93 (Table 3).

\section{Growth In Commerclal Floorspace}

The projection for commercial floorspace is an area where significant adjustments were made. The AEO93 Reference Case projection for floorspace was based on projected growth in the commercial services sector

6. Energy Information Administration, Assumptions for the Annual Energy Outlook 1993, DOE/ELA-0527(93) (Washington, DC, Jan. 1993). 
Table 3. Economic Assumptions: Comparison of AEO93 and Administration Baseline Cases (Annual Growth Rates, 1990 to 2000)

\begin{tabular}{|l|c|c|}
\hline \multicolumn{1}{|c|}{ Assumption } & AEO93 & Administration Baseline \\
\hline Real GDP & 2.2 & 2.3 \\
\hline Population & 0.8 & 0.7 \\
\hline Residential Housing Stock & 0.9 & 0.9 \\
\hline Commercial Floorspace & 1.9 & 1.3 \\
\hline Industrial Production Index & 2.5 & 2.5 \\
\hline $\begin{array}{l}\text { Average Annual Improvement in } \\
\text { Energy Intensity }\end{array}$ & 1.0 & 1.4 \\
\hline
\end{tabular}

of Gross Domestic Product (GDP). Several reviewers noted that the rapid growth in floorspace in the $A E 093$ forecast was contrary to the prevailing industry view that the commercial real estate market was already overbuilt. Moreover, further analysis showed that historical growth in commercial floorspace was more highly correlated with either total employment or population than with commercial sector GDP. Given these considerations, a methodology based on these alternative correlations was adopted to project floorspace growth in the Administration Baseline. EIA has indicated that the AEO94 will also use this type of relationship.

\section{Industrial Energy Intensity}

Average energy intensity is a measure of energy use relative to industrial output. Historically, industrial energy intensity has declined due to a combination of factors, including changes in the sectoral composition of industry, changes in the product mix within individual industries, technological changes in production (sometimes referred to as autonomous efficiency improvements), and energy conservation in response to higher energy prices. For example, changes in structural composition reduce energy intensity when output from energy-intensive industries (such as paper or steel) increases more slowly than output from less energy-intensive industries (such as electronics). The AEO93 projection of energy intensity in the industrial sector was reviewed by the interagency team. The staff of Lawrence Berkeley Laboratory assisted in this effort.

The projected reduction in industrial energy intensity in the $A E O 93$ is 1.0 percent per year. When the effects of ongoing DOE R\&D programs were included (as described below), the projected intensity reduction increased to 1.3 percent per year. An independent analysis by Dr. Lee Schipper and associates at Lawrence Berkeley Laboratories evaluated historical energy intensity trends and concluded that annual intensity reductions over the remainder of the decade were likely to fall within the range of 1.4 to 2.9 percent per year. After considerable discussion of the available evidence, the interagency team decided that an estimate of 1.4 percent per year was most appropriate for the Administration Baseline.

\section{Transportation and Military Energy Use}

\section{Automoblle Transportation}

The underlying assumptions for vehicle use and vehicle fuel efficiency were carefully reviewed by the interagency team. The focus was on the light-duty vehicle (LDV) sector (cars and light trucks), whose emissions comprised roughly 60 percent of the transportation total in 1990 . The key assumptions for this sector are vehicle miles traveled (VMT), average EPA-rated fuel economy of the new car fleet in miles per gallon (mpg), and the gap between EPA ratings and on-road performance (often referred to as the "gap factor"). Several alternative scenarios were explored. The assumptions ultimately adopted are reported together with the AEO93 assumptions in Table 4. The differences between the two sets of 
assumptions are minor. Note that because the AEO93 model and the IDEAS model use different vehicle weight cut points to divide the fleet into light- and heavy-duty vehicles, the projections for the individual components are not strictly comparable.

Table 4. Transportation Sector: Comparison of Administration Baseline and AEO93 Assumptions

\begin{tabular}{|l|c|c|}
\hline \multicolumn{1}{|c|}{ Assumption } & AEO93 & $\begin{array}{c}\text { Adminiatration } \\
\text { Basoline }\end{array}$ \\
\hline Light-duty VMT growth, 1990-2000 (percent) & 1.8 & 2.2 \\
\hline Now car fuel officiency, 2000 (miles per gallon) & 30.3 & 30.0 \\
\hline Now light-duty truck fuel efficiency, 2000 (miles per gallon) & 22.7 & 24.3 \\
\hline "Gap factor," 2000: & $\mathrm{NA}$ & 0.18 \\
Cars & $\mathrm{NA}$ & 0.27 \\
\hline Light trucks & 2.0 & 2.5 \\
\hline Growth in heavy-duty vehicle miles traveled, 1990-2000 (percent) & 0.8 & 0.8 \\
\hline Growth in new heavy-duty vehicle fuel efficiency, 1990-2000 (percent) & 18.7 & 18.6 \\
\hline Total energy consumptior, by vohicles, 2000 (quadrillion Btu) & \\
\hline
\end{tabular}

\section{Military Energy Use}

The AEO93 projections of military aircraft petroleum consumption were updated to take into account the latest Defense budget reductions. The revised aircraft fuel use level for the year 2000 is 0.2 quadrillion Btu lower than in the AEO93. The revised projections were consistent with projections from the Federal Aviation Administration (FAA) and DRI-McGraw Hill.

\section{Environmental Controls and Technology Costs in the Utility Sector}

EIA's assumptions concerning the utility industry's response to the Clean Air Act Amendments of 1990 were reviewed by the interagency team. Based on utility compliance plans submitted to EPA, the projected installation of scrubbers by 2000 was increased from 8.1 gigawatts (GW) of capacity in the AEO93 to $22 \mathrm{GW}$. In addition, 1 to 2 percent of coal boilers are assumed to co-fire seasonally with natural gas by 2000.

On the technology side, recent reductions in wind project costs and expectations for continued progress led DOE to review the wind technology cost assumption. As a result, the wind capital cost assumption was reduced from $\$ 1,034$ per kilowatt $(\mathrm{kW})$ to $\$ 759$ per $\mathrm{kW}$ by the year 2000 (in 1991 dollars). The full set of utility technology costs, which are also affected by ongoing R\&D efforts are reported in Table 12 below.

\section{Carbon Coefficients}

In October 1993, EIA published an update of carbon coefficients and estimated carbon emissions from the energy sector in 1990 as part of its statutorily mandated Emission Inventory. The carbon coefficients differ slightly from those in the $A E 093$, resulting in a slight change in gross U.S. carbon emissions-from 1,340.5 million metric tons (MMT) in the AEO93 to 1,338.0 MMT in the inventory. The carbon emission factors used by the IDEAS model, which reflect a higher level of aggregation than the coefficients developed by EIA for purposes of completing the emissions inventory, were adjusted to be consistent with the carbon estimates in the 1990 inventory. The aggregate coefficients are reported in Table 5. 
Table 5. Carbon Emission Coefficients

\begin{tabular}{|l|c|}
\hline \multicolumn{1}{|c|}{ Fuel Type } & $\begin{array}{c}\text { Emission Rate } \\
\text { (million motric tons per quadrillion Btu) }\end{array}$ \\
\hline Coal & 25.33 \\
\hline Crude oil & 20.98 \\
\hline Natural gas & 14.54 \\
\hline Gasoline & 19.42 \\
\hline Diesel & 19.97 \\
\hline Jet fuel & 19.46 \\
\hline Synthetic natural gas & 20.00 \\
\hline
\end{tabular}

\section{Baseline Assumptions}

Some of the key assumptions underlying the Administration Baseline are described below. The focus is on the demand sectors-residential and commercial buildings, industry, and transportation-and the electricity supply sector.

\section{Buildings Sector}

The IDEAS model projects energy consumption for five fuel types (liquids, natural gas, coal, electricity, and renewables) across six end-use categories (space heating, space cooling, thermal, refrigeration, lighting, and appliances) in the residential and commercial sectors. Major assumptions for these sectors can be organized into two groups: building stock characteristics and financial parameters.

\section{Bullding Stock Characteristics}

The model assumes that each housing unit or thousand square feet of commercial building space in the buildings sector generates a mixture of end-use service demands. The service-demand concept recognizes that energy itself is an input to the production of valued services-heat, hot water, light, and so forthrather than a product whose consumption is valued directly. These service demands are grouped into six end-use categories: space heating, space cooling, thermal, refrigeration, lighting, and appliances. The thermal end-use category includes water heating, clothes drying, and cooking. The appliances end-use category includes television sets, clothes washers, radios, and so forth.

The single most important input to the buildings sector is the forecast of future building stock, since growth in fuel use is largely a function of growth in service demand (Table 3). It is assumed that each housing unit or thousand square feet of commercial building space generates, on average, a certain amount of space heating, space cooling, thermal use, and appliance use. Appliance and air conditioning saturations may lead to increased service demand per home or per thousand square feet of space (Table 6). A capital stock turnover structure in the model keeps track of additions and retirements of buildings and appliances by fuel type, based on physical lifetimes (Table 7). Energy consumption for each end-use category is calculated on the basis of stocks, energy prices, conservation investments, and behavioral adjustments. 
Table 6. Appllance and Alr Conditioning Saturation Assumptions for the Residentlal and Commerclal Sectors

\begin{tabular}{|c|c|c|c|c|c|}
\hline \multirow[b]{2}{*}{ Yoar } & \multicolumn{3}{|c|}{ Residential Soctor } & \multicolumn{2}{|c|}{ Commercial Sector } \\
\hline & $\begin{array}{c}\text { Small Appliances } \\
\text { per Homo } \\
(1990=1.00)\end{array}$ & $\begin{array}{l}\text { Homes with } \\
\text { Air Conditioning } \\
\text { (percent) }\end{array}$ & $\begin{array}{c}\text { Thermal Appliances } \\
\text { per Home* } \\
(1990=1.00)\end{array}$ & $\begin{array}{l}\text { Appliances per } \\
1,000 \mathrm{Sq} . \text { Feot } \\
(1990=1.00)\end{array}$ & $\begin{array}{l}\text { Facilltios with } \\
\text { Air Conditioning } \\
\text { (percent) }\end{array}$ \\
\hline 1990 & 1.00 & $58 \%$ & 1.00 & 1.00 & $70 \%$ \\
\hline 1995 & 1.13 & $62 \%$ & 1.01 & 1.18 & $72 \%$ \\
\hline 2000 & 1.41 & $66 \%$ & 1.02 & 1.37 & $74 \%$ \\
\hline
\end{tabular}

"Includes water heating, clothes drying, and cooking.

Table 7. Bullding Stock Llfetime and Dlscount Rate Assumptlons for the Residentlal and Commerclal Sectors

\begin{tabular}{||l|c|c||}
\hline \multicolumn{1}{|c|}{ Soctor and End-Use Category } & $\begin{array}{c}\text { Average Lifetime } \\
\text { (years) }\end{array}$ & Consumer Hurdle Rate \\
\hline Residentlal Sector & & 0.20 \\
Space Heating & $50^{*}$ & 0.50 \\
Space Cooling & $50^{*}$ & 0.25 \\
Thermal & 15 & 0.50 \\
Lighting & 5 & 0.50 \\
Refrigeration & 20 & 0.50 \\
Appliances & 15 & \\
Commercial Soctor & & 0.25 \\
Space Heating & 50 & 0.50 \\
Space Cooling & 50 & 0.60 \\
Thermal & 15 & 0.60 \\
Lighting & 12 & 0.60 \\
Refrigeration & 20 & 0.60 \\
Appliances & 10 & \\
\hline
\end{tabular}

"The average lifetimes for these end-use categories represent an average for the structure and appropriate appliances.

\section{Financlal and Behavioral Factors}

For many end-use demand categories, several different technologies, sometimes using different fuels, can satisfy the demand for energy services. The relative amount of each technology added each year is determined by a market-share algorithm based on the concept of energy-service cost. The energy-service cost of a technology measures the cost (per quadrillion Btu) of supplying energy services, including a capital cost component and a fuel cost component. The capital cost component includes the first cost of the technology, the additional cost of any conservation measures purchased, the capital recovery factor, and the base-service demand. The fuel cost component includes the cost of the fuel, the savings derived from any conservation measure purchased, and the efficiency of the technology. It is assumed that the lowest cost option will be selected, so the market-share equation computes the probability that each technology will be less expensive than all others. The resulting market shares are used to determine what fuels and technologies will be used in new building stock to satisfy the energy-service demands. 
Conservation investment for each end use is calculated on the basis of fuel prices, "consumer hurdle rates" (Table 7)-which capture the consumer tradeoff between investing in conservation technology today and projected fuel savings in the future, existing stock efficiencies, and characteristics of new conservation technologies. Fuel prices are generated within the model. Conservation characteristics for each end use are represented by two curves in the model-the conservation marginal-cost curve and the conservation total-cost curve. The conservation marginal-cost curve represents the total savings from technology measures that fall below a given marginal capital cost (first-cost investment divided by annual energy savings); the conservation total-cost curve represents the total cost of these measures on a perunit basis (per home or per thousand square feet of commercial floorspace).

Examples of two residential and commercial conservation marginal-cost curves are show 1 in Figures 8 and 9. The conservation total-cost curves are derived from marginal-cost curves. Each curve is an aggregation of individual c'snservation measures and end-use technologies ordered by marginal capital cost in dollars per million Btu of savings. Because the costs of some measures are specific to regions and building types, measures are given for different regions and buildings where appropriate. Although the IDEAS integrating energy model is not a regional model, regional differences in technology performance are captured in these curves in order to replicate regional effects.

\section{Figure 8. Conservation Cost-Savings Curve, Residential-Refrigeration}

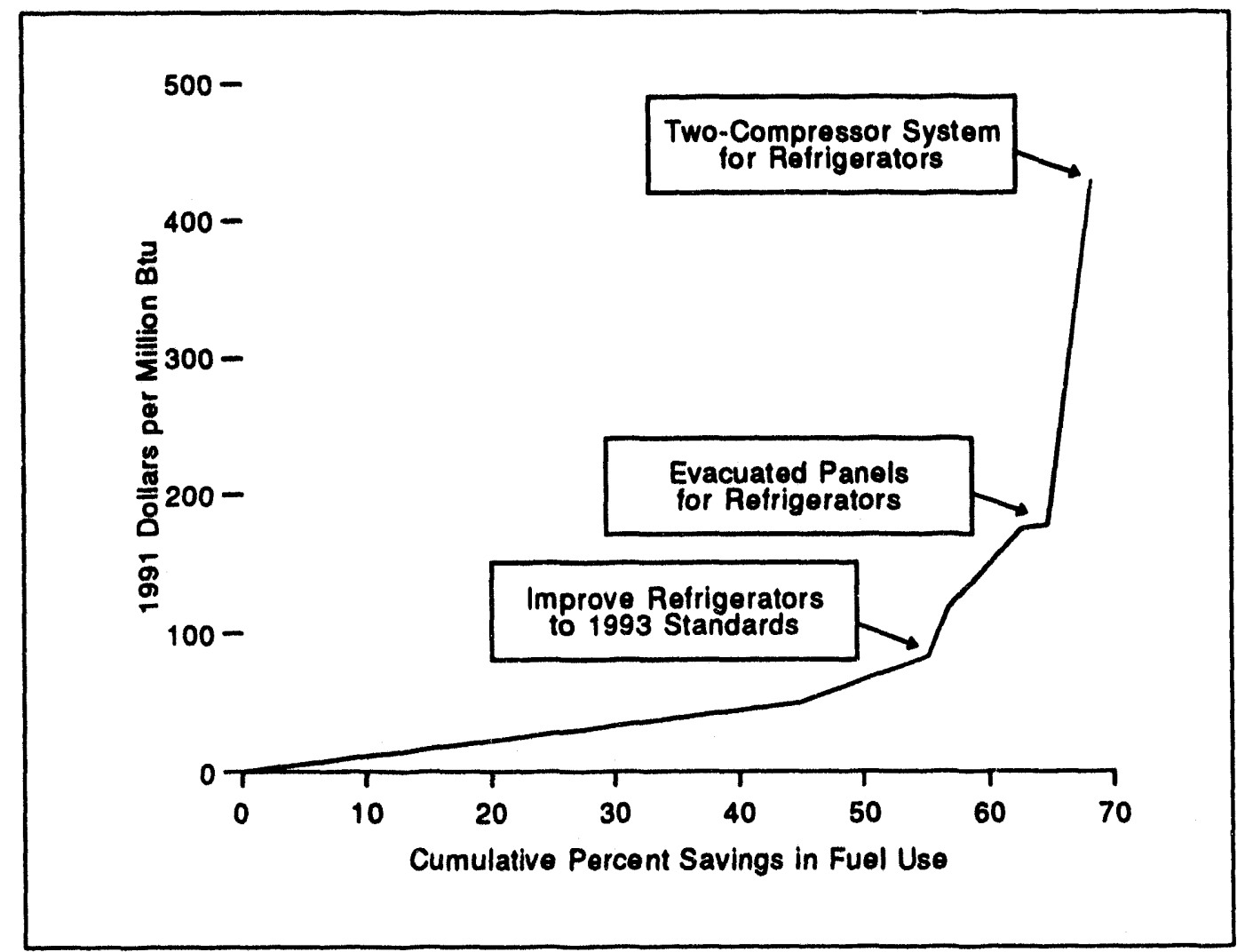

\section{Industrial Sector}

For the industrial sector, the IDEAS model projects energy consumption for five fuel types (liquids, natural gas, coal, electricity, and renewables). Due to the aggregate nature of IDEAS, consumption is projected across five end-use categories (steam, process heat, feedstocks, machine-drive and electrolytic processes, and cogeneration) rather than by Standard Industrial Classification (SIC) category. Major 
Figure 9. Conservation Cost-Savings Curve, CommercialElectric Space Heating

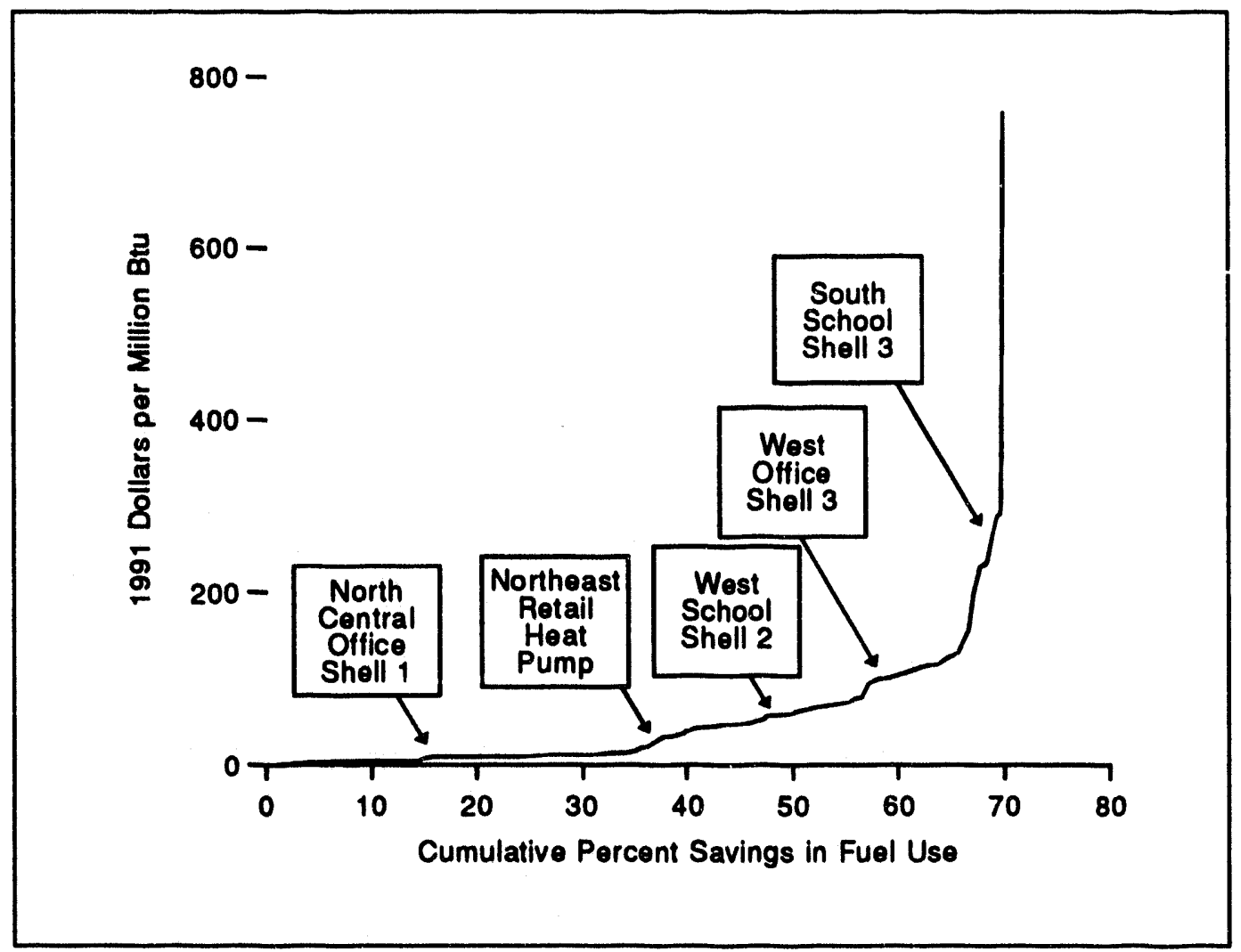

assumptions for this sector can be organized into three groups: industrial production assumptions, capital stock characteristics, and financial parameters.

\section{Industrial Production Assumptions}

Growth in industrial production is the underlying cause of increased energy use in industry. The total industrial production assumption is given in Table 3. As evidenced by the experience of $1980 \mathrm{~s}$, however, consumption does not increase as rapidly as output, because of the effects of energy management, energy conservation, changes in manufacturing processes, and shifts in the industrial mix. Energy management and conservation investments are price-induced and treated through behavioral response and conservation supply curves. Changes in processes, products, and mix are addressed through industrial product and process change curves.

Three factors are captured in the industrial product and process change curves. The first factor is the mix of industrial output. Since energy intensity varies by industry, relative growth among different industries can significantly affect total consumption. For instance, the current trend of faster growth in light industries is expected to continue, although at a slower rate than historically, resulting in less total energy consumption per unit of output. The second factor is the shift in product mix within each industry. Energy intensity can vary by product, so changes in product mix can also affect total consumption. An example is the continuing trend in the chemical industry away from basic chemicals and toward less energy-intensive, higher value-added chemical products, which will reduce total energy consumption in that industry. The third factor is changes in industrial processes. New processes installed to raise productivity can often substantially reduce energy consumption. An example is the shift from open-hearth furnaces to mini-mills in the steel industry. The current assumptions are shown in Table 8. 
The Climate Change Action Plan: Technical Supplement

Table 8. Industrial Product/Process Change Multipllers

\begin{tabular}{|c|c|c|c|}
\hline Year & $\begin{array}{c}\text { Steam } \\
(\mathbf{1 9 9 0}=\mathbf{1 . 0 0 )}\end{array}$ & $\begin{array}{c}\text { Machine Drive } \\
(\mathbf{1 9 9 0}=\mathbf{1 . 0 0 )}\end{array}$ & $\begin{array}{c}\text { Other Process Heat } \\
(\mathbf{1 9 9 0}=\mathbf{1 . 0 0 )})\end{array}$ \\
\hline 1990 & 1.00 & 1.00 & 1.00 \\
\hline 1995 & 0.98 & 1.00 & 0.98 \\
\hline 2000 & 0.96 & 0.99 & 0.95 \\
\hline
\end{tabular}

\section{Capital Stock Assumptions}

As stated above, the industrial sector has five basic end uses: steam, process heat, machine-drive and electrolytic processes, cogeneration, and feedstocks. The steam service demand sector represents the demand for process steam, which may be satisfied by boilers or by cogeneration. Process heat represents direct heat applications in specific industrial processes, such as glassmaking, calcining, petroleum refining, and chemical refining. Machine-drive and electrolytic processes account for most industrial electricity consumption. Feedstocks are exogenous assumptions based on the detailed industrial macroeconomic inputs.

A capital stock turnover structure in the industrial sector calculates fuel use and average efficiencies over time by adding, vintaging, and retiring stock. As old, inefficient stock is replaced by new, efficient stock, overall energy efficiency increases. The assumed capital stock lifetimes are shown in Table 9 below.

\section{Financial and Behavioral Factors}

The energy-service cost approach is used to compute technology market shares in the industrial sector, as in the buildings sectors. Competing fuels are compared on an energy service cost basis, consisting of capital, fuel, and operating and maintenance costs.

Conservation investment for each end use is calculated as in the residential and commercial sectors: on the basis of fuel prices, the capital charge rates, existing stock efficiencies, and characteristics of new conservation technologies. Fuel prices are generated within the model. Capital charge rates, which depend on the industry hurdle rate, investment rate, and tax rates, are shown in Table 9. Conservation characteristics for each end use are represented by the conservation marginal-cost curve and the conservation total-cost curve. An example of the industrial machine-drive and electrolytic process conservation curve is given in Figure 10.

Table 9. Stock Llfetime and Capital Charge Rate Assumptlons for the Industrial Sector

\begin{tabular}{|l|c|c|}
\hline \multicolumn{1}{|c|}{ End-Use Category } & $\begin{array}{c}\text { Average Stock Lifetime } \\
\text { (years) }\end{array}$ & Capital Charge Rate \\
\hline Steam & 25 & 0.25 \\
\hline Machine Drive & 20 & 0.28 \\
\hline Other Process Heat & 25 & 0.25 \\
\hline Cogeneration & 25 & 0.22 \\
\hline
\end{tabular}


Figure 10. Conservation Cost-Savings Curve, IndustrialMachine Drive/Electrolytlc

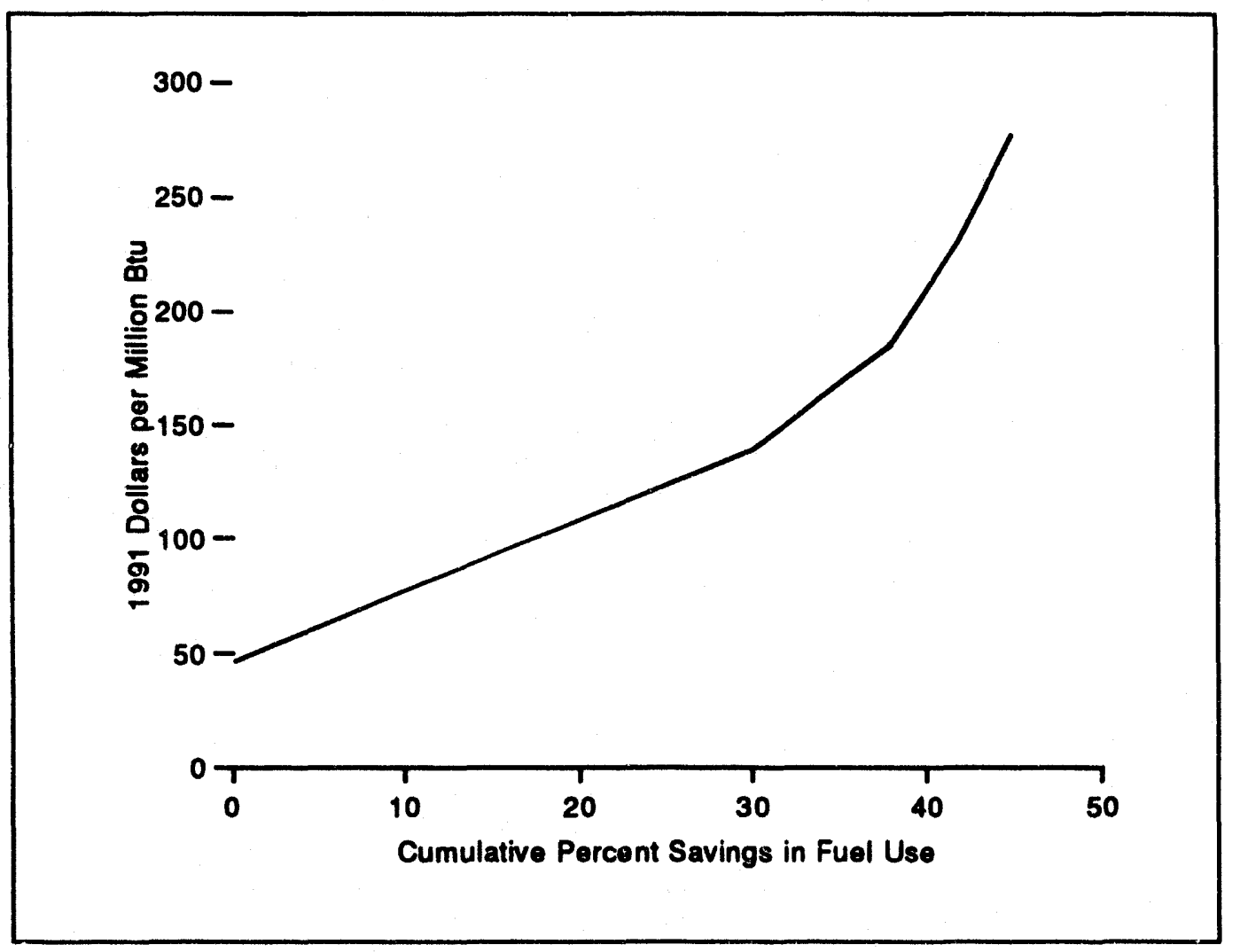

\section{Transportation Sector}

The transportation sector is categorized into light-duty vehicles, heavy-duty vehicles, air, marine, rail, and other transportation. Because highway vehicles account for more than three-quarters of total transportation energy consumption, they are modeled in the most detail. For each vehicle type, fuel prices and economic and demographic information from the IDEAS model are used to compute fuel use for the rest of the model.

The light- and heavy-duty vehicle sector of the model is divided into six subsectors: car ownership, fuel choice, efficiency, vehicle miles traveled, vintaging, and scrappage. The model endogenously forecasts vehicle sales, the choice between different fueled vehicles, the efficiency of the new vehicle stock, the number of miles vehicles are driven, the specific choice of fuels for multi-fueled vehicles, and the amount of fuel used. Fuel prices affect four types of decisions that consumers make: the number of vehicles of each type to own; the type of fuel to use; the efficiency of the new vehicle; and the number of miles to drive each vehicle. The efficiency submodule combines engineering data with economic calculations to compute long-term and short-term price-induced conservation savings. Outputs from this submodule include final on-road efficiency (miles per quadrillion Btu), final vehicle purchase prices, and performance specifications (horsepower). The efficiencies and fuel prices together determine operating costs (dollars per mile), which are used to predict vehicle miles traveled (miles per average vehicle). In combination with performance, purchase price, and other characteristics, operating costs also help determine the fuel market shares for new vehicles in eaih vehicle size class and fuel type. Total demand for each size class is a function of the number of households, household income, and the expected value that consumers place on the characteristics of each size class. New vehicle purchases are added to the existing vehicle stock, and the result is used with the efficiency and vehicle miles traveled forecasts to compute vehicle fuel use in the vintaging subsector. 
The vintaging subsector integrates data from the other five subsectors. At its simplest, it keeps track of the characteristics of the historical vehicle stock and computes fuel use on the basis of these characteristics. Total vehicle sales are tracked discretely in an aging chain over a period of 20 years and are disaggregated by vehicle type, size class, fuel type, and age. Age-specific survival rates are computed in the scrappage subsector and are used to determine the remaining vehicle stock by size class. In the model, the survival rate is represented mathematically by an S-shaped functional form dependent in part on the average lifetime of a vehicle. The average lifetime is defined as the number of years at which 50 percent of the cars have retired. As shown in Table 10, average lifetime is specific for each size class.

Table 10. Stock Llfetime Assumptions for the Transportation Sector

\begin{tabular}{|l|c|}
\hline \multicolumn{1}{|c|}{ Vohiclo Type } & \multicolumn{1}{|c|}{$\begin{array}{c}\text { Average Lifotimo } \\
\text { (years) }\end{array}$} \\
\hline Light-Duty Cars & 14 \\
\hline Light-Duty Trucks & 15 \\
\hline Light Hoavy-Duty Trucks & 12 \\
\hline Medium Heavy-Duty Trucks & 10 \\
\hline Heavy Heavy-Duty Trucks & 7 \\
\hline Buses & 12 \\
\hline
\end{tabular}

Fuel use is computed on the basis of the surviving stock from each of the previous 20 model years, vehicle miles traveled (adjusted for the age of the vehicle), vehicle efficiency for each of the previous 20 model years (also adjusted for the age of the vehicle), and projected fuel-specific mileage shares for multi-fuel vehicle types. Annual vehicle miles traveled are computed for the average car according to an econometric equation based on vehicle operating cost.

The technology cost and savings curves for the transportation sector are derived from individual technology data represented in database form. These curves are designed to represent long-term ( $>5$ years) changes in performance and efficiency that result from major chassis and drive train redesign and the adoption of new materials and technologies. From these curves, three interrelated characteristics of technology costs and savings are calculated in the model: marginal cost, cumulative measure savings, and cumulative measure cost. The marginal cost of a measure is the cost of each additional percent fuel savings achieved by purchasing the measure. The technology measure database is sorted in order of increasing marginal cost, 80 that those measures that have the largest savings per dollar spent will be selected before other measures that have smaller savings per dollar spent. Hence, the last measure selected will have the highest marginal cost. The cumulative savings measure is the total savings achieved by installing all measures up to and including the current measure. Figure 11 is an illustration of one of the curves showing the total savings that can be achieved by adopting all measures with a cost less than or equal to a certain amount per percent fuel saved. The cumulative cost measure is the cost of adopting all measures up to and including the current measure.

\section{Electricity Generation}

The electricity supply sector of the IDEAS model projects electricity supply and prices. The sector builds new capacity in response to future demand, dispatches capacity to satisfy current demand (determined by the demand sectors), and sets electricity rates. The resulting prices are fed back to the demand sectors in order to determine current and future electricity load growth. 
Figure 11. Conservation Cost-Savings Curve, TransportationLarge Autos, 2000

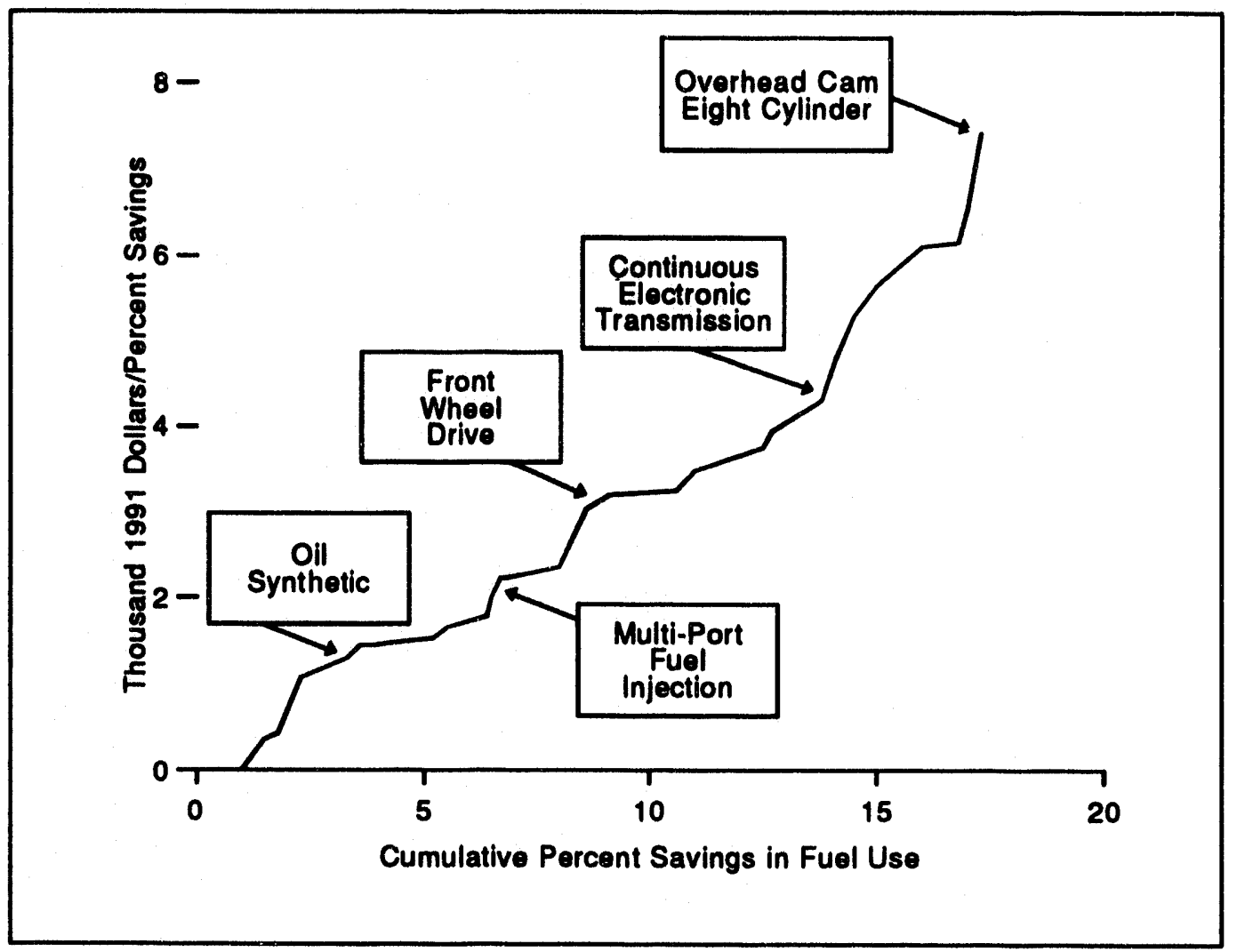

The model estimates the quantity of new capacity required in each time period, based on the projected load growth and the levels of both existing capacity and capacity under construction. Technologies compete for shares of the market for new capacity on the basis of a least-cost algorithm. The model includes costs and performance characteristics for the 23 different technologies shown in Table 11. Those that are assumed to be commercially available by 2000 are shown in Table 12 . In addition to the technologies listed, the model can explicitly life-extend oil, gas, and coal steam plants, repower coal plants using several technologies, and convert gas combined-cycle plants to Integrated Gas Combined Cycle (IGCC) by installing a coal gasifier. The levelized cost per kilowatt-year is calculated for each technology in each time period, based on capital costs, financial charges, operating and maintenance costs, fuel costs, and the efficiency of the equipment (Table 12). Construction decisions for new capacity are made on the basis of the costs, resulting in a mix of least-cost technologies. The model uses a logit-based market shares algorithm to avoid "knife-edge" construction decisions that cause all additional requirements to be met by a single technology. Electricity rates are then calculated on the basis of the capital and operating costs of the resulting capacity mix.

A national-level load-duration curve, together with technology costs, determines the capacity dispatching order. In a given time period, technologies within the capacity mix are dispatched on the basis of increasing fuel costs and variable operation and maintenance costs. This typically translates into the dispatch order of baseload hydroelectric, nuclear, baseload coal, baseload oil and gas, renewables, intermediate coal, intermediate oil and gas, and, finally, pumped-storage hydroelectric and combustion turbines for peak load. Electricity imports are an exogenous assumption in the model.

As the need for new capacity grows, utilities are expected to explore demand-side management (DSM) programs as a key component of their overall Integrated Resource Planning (IRP) efforts. DSM savings assumptions are based on the AEO93 Reference Case. 
Table 11. Electriclty Generation Technologles Represented In the IDEAS Model

\begin{tabular}{|c|c|c|c|}
\hline Coal & OivNatural Ges & Nuclear & Renowables \\
\hline $\begin{array}{l}\text { Coal steam } \\
\text { Coal steam with fluidized } \\
\text { gas desulfurization } \\
\text { Atmospheric fluidized bed } \\
\text { Pressurized fluidized bed } \\
\text { Integrated gasification } \\
\text { combined cycle } \\
\text { Coal gasification } \\
\text { steam-injected turbines } \\
\text { Coal gasification fuel cells }\end{array}$ & $\begin{array}{l}\text { Oilgas steam } \\
\text { Gas steam } \\
\text { Gas combined cycle } \\
\text { Gas fuel cells } \\
\text { Combustion turbines } \\
\text { Steam-injected turbines } \\
\text { Intercooled steam- injected } \\
\text { turbines }\end{array}$ & $\begin{array}{l}\text { Light-water reactors } \\
\text { Advanced light-water } \\
\text { reactors } \\
\text { Second-generation nuclear }\end{array}$ & $\begin{array}{l}\text { Hydroelectric } \\
\text { Solar photovoltaic } \\
\text { Solar thermal } \\
\text { Wind } \\
\text { Biomass } \\
\text { Geothermal }\end{array}$ \\
\hline
\end{tabular}

Table 12. Electricity Generation Technology Characteristics in the IDEAS Model, Year 2000

\begin{tabular}{|c|c|c|c|c|c|}
\hline Technology & $\begin{array}{l}\text { Capital Cost } \\
\text { (1991 dollars } \\
\text { per kilowatt) }\end{array}$ & $\begin{array}{l}\text { Oporating and } \\
\text { Maintonance } \\
\text { Costs } \\
\text { (1891 mills por } \\
\text { kilowatthour) }\end{array}$ & $\begin{array}{l}\text { Hoat Rate } \\
\text { (Btu per } \\
\text { kilowatthour) }\end{array}$ & $\begin{array}{l}\text { Commorciall- } \\
\text { zation Yoar }\end{array}$ & $\begin{array}{c}\text { Maximum } \\
\text { Utilization } \\
\text { Rato }\end{array}$ \\
\hline \multicolumn{6}{|l|}{ Nonronewable } \\
\hline $\begin{array}{l}\text { Emissions-controlled } \\
\text { pulverized coal }\end{array}$ & 1,662 & 14.8 & 10,340 & ** & 0.70 \\
\hline Coal-atmospheric fluidized bed & 1,408 & 11.1 & 9,750 & ** & 0.84 \\
\hline Oilvas steam & 1,039 & 5.8 & 9,900 & $*$ & 0.65 \\
\hline Gas combined cycle & 577 & 4.6 & 7,300 & $*$ & 0.84 \\
\hline Gas fuel cell & 921 & 10.6 & 6,450 & 1997 & $n / a$ \\
\hline Combustion turbine & 337 & 5.7 & 13,500 & $\cdots$ & 0.86 \\
\hline \multicolumn{6}{|l|}{ Non-fosail } \\
\hline Solar photovoltaic & 2,525 & 2.2 & $\cdots$ & 1995 & 0.28 \\
\hline Solar thermal & 1,733 & 9.8 & - & ** & 0.37 \\
\hline Solar thermal with gas backup & 1,731 & 6.9 & -. & $\omega$ & 0.37 \\
\hline Wind electric & 759 & 19.9 & -- & * & 0.30 \\
\hline Geothermal & 2,169 & 16.4 & $\cdots$ & 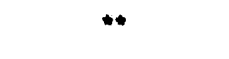 & 0.83 \\
\hline Biomass & 1,092 & 9.7 & 10,000 & 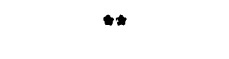 & 0.70 \\
\hline Light-water nuclear & 1,846 & 29.2 & 10,800 & $*$ & 0.70 \\
\hline Advanced nuclear & 1,616 & 4.9 & 10,200 & 1996 & 0.70 \\
\hline
\end{tabular}

* Currently available. 


\section{Additional Baseline Policies Affecting Energy-Related Emissions}

The Administration Baseline includes the expected impacts of current Government policies and programs. Not all of these were included in the $A E O 93$ projections, and modifications were made where appropriate.

\section{FERC Order 636}

FERC Order 636 is expected to improve access to gas pipelines and lower costs to many types of large gas consumers. These changes will help to stimulate the use of natural gas. Since the AEO93 did not explicitly account for market changes resulting from this Order, an adjustment was made in the Administration Baseline to reflect its impact. Specifically, gas availability was assumed to increase for all sectors, thus increasing the market share for natural gas in end-use markets. Gas pipeline transmission costs were assumed to be reduced by $\$ 0.03$ per thousand cubic feet for the residential sector, \$0.04 per thousand cubic feet for the commercial sector, \$0.04 for the industrial sector, and \$0.01 for the utility sector. These changes result in an increase of 0.6 quadrillion Btu in primary gas consumption in the year 2000 and a carbon reduction of $4 \mathrm{MMT}$, consistent with independent estimates of the effects of these market reforms.

\section{Efficiency Standards in the Energy Policy Act of 1992}

The AEO93 Reference Case was completed before final passage of the Energy Policy Act of 1992 (EPACT). While EIA did consider the House and Senate versions of the bill in developing the AEO93, it adopted a consistently conservative approach in that only the impacts from standards and policies explicitly determined in both the House and Senate versions of the legislation were considered. In most cases, the assumptions used by EIA for these standards were consistent with the final language of the bill. One exception is residential building standards, which the final statutory language made optional for the States rather than mandatory, as had been assumed by EIA. As a result, the effects of the residential building standards were removed from the Administration Baseline.

Another adjustment was made in allocating the impact of electric motor standards. In the AEO93 Reference Case, all the projected savings from these standards were allocated to the industrial sector. For the Administration Baseline, roughly one-third of the projected energy savings were allocated to the commercial sector, in recognition of the extensive use of covered motors in commercial establishments for heating, ventilation, and air conditioning (HVAC) and other purposes. The remaining two-thirds of the projected energy savings remained in the industrial sector.

Impacts from other policies, such as manufactured housing standards, showerhead standards, commercial building standards, HVAC standards, lamp and high-intensity discharge (HID) standards, office equipment labeling, renewable fuels tax and production credits, and nuclear licensing reform were assumed to be the same as in the AEO93 Reference Case.

The impact on carbon emissions from all the EPACT provisions (excluding R\&D) is estimated to be a reduction of roughly 15 MMT of carbon in the year 2000.

\section{Energy Pollcy Act Research and Development Programs}

EPACT also authorizes additional R\&D funding for DOE programs in the areas of energy efficiency and renewables, fossil fuels, and nuclear technologies. The effects of these programs, which will augment ongoing R\&D programs, have been estimated by the various offices within DOE. Energy savings projected to result from the EPACT efficiency-related R\&D programs are reported below (Table 13).

The effect on carbon emissions from all energy R\&D programs is estimated to be roughly 12 MMT of carbon in the year 2000. 
R\&D programs in the area of electricity generation are projected to reduce the future cost and improve the performance of new technologies. The year-2000 technology characteristics for the Administration Baseline can be found in Table 12.

Table 13. Energy Savings In 2000 (Quadrillion Btu of Primary Energy)

\begin{tabular}{|l|c|}
\hline \multicolumn{1}{|c|}{ Source of Sovings } & Administration Baseline \\
\hline Advanced buildings design & 0.13 \\
\hline Heat pump research and development & 0.02 \\
\hline industry grants and audits & 0.10 \\
\hline Waste reduction research and development & 0.15 \\
\hline Pulp and paper research and development & 0.05 \\
\hline Electric drives research and development & 0.25 \\
\hline
\end{tabular}

\section{Voluntary and Utility Programs}

The impact of ongoing voluntary programs to improve U.S. energy efficiency were not included in the AE093. These programs, such as the "Green Lights" program, ask major corporations and institutions to commit to making efficiency improvements that are cost-effective. Green Lights also provides technical assistance to implement such improvements. These programs are already having a measurable impact. For example, EPA reported in its November 1993 Green Lights Update that over 3,600 projects covering more than $\mathbf{4 0 0}$ million square feet of space were already in the upgrade pipeline.

To reflect the efficiency impact of the Green Lights program, the Administration Baseline assumes that 16 percent of commercial floorspace will be affected by the program and achieve a 55- to 60-percent reduction in lighting energy consumption by the year 2000. For the Energy Star Buildings program, which pursues energy efficiency improvements in commercial heating and cooling systems, the Administration Baseline projects 30 - to 50 -percent savings for roughly 3 percent of commercial floorspace by the year 2000 .

The existing Energy Star Computer and Golden Carrot Refrigerator programs work with manufacturers to promote production and marketing of high-efficiency products. The Energy Star Computers program, which has already been joined by most major manufacturers, is projected to cut energy use in the Administration Baseline by roughly 55 percent in 65 percent of the computers in use in the year 2000.

Through the Super Efficient Refrigerator Program, a consortium of electric utilities sponsored a competition among manufacturers that offered a guaranteed minimum order for the winning highefficiency refrigerator design. The winning design, announced by the consortium in the summer of 1993 , is projected to consume only 40 to 50 percent of the electricity of a refrigerator meeting the 1993 minimum efficiency standard. This program, which accelerates the introduction of highly energy-efficient refrigerators into the marketplace, is projected to reduce electricity demand in the Administration Baseline by 3 billion kilowatthours in the year 2000.

The voluntary programs to promote cost-effective investments in energy efficiency cited above complement efficiency standards programs and utility-sponsored and regulator-approved demand-side management programs. Taken together, ongoing efforts not included in the AEO93 Reference Case are projected to reduce carbon emissions in the Administration Baseline by 17 MMT in the year 2000. 


\section{The Administration Economlc Package}

The February 1993 Administration economic package included several initiatives that would reduce energy consumption. These include increases in the weatherization assistance program, the Federal buildings efficiency program, natural gas utilization R\&D, as well as reform of the Federal Power Marketing Agency system. Although Congress did not act favorably on these proposals in the final budget for fiscal year 1994, the Administration is continuing to seek future funding. The Administration Baseline assumes that future-year funding will be approved. Together, these programs are projected to reduce carbon emissions by a modest 3 MMT in 2000.

\section{Transportation and Motor Fuel Taxes}

The budget reconciliation package enacted into law in August 1993 includes a 4.3-cents-per-gallon Federal transportation fuels tax increase for gasoline, diesel, and jet fuel. This tax, which went into effect in October 1993 (and thus postdates completion of the AEO93), includes exemptions for alcohol, nonhighway gasoline and diesel use, and jet fuel used for international aviation. The tax is projected to lower fuel consumption and reduce carbon emissions by 4 MMT in 2000 in the Administration Baseline.

The AEO93 Reference Case assumes that, except for an already-scheduled increase, State and local gasoline taxes will remain at their present level in nominal terms-i.e., that they fall in real terms. A review of recent data showed that these taxes have steadily increased in real terms. While it is impossible to forecast the exact timing or pattern of future tax changes across individual jurisdictions, there is no reason to believe that the underlying forces that have driven recent trends in these taxes have suddenly changed. Therefore, the Administration Baseline extrapolates the recent trend, resulting in a national average increase of 3.8 cents per gallon (in 1991 dollars) in motor fuel taxes at the subfederal level by the year 2000. The impact on carbon emissions in 2000 is slightly more than 3 MMT.

\section{Methane Baseline Assumptions}

Methane emissions in 1990 are estimated to be 166 MMTce (Table 14). These emissions are expected to decrease in the Administration Baseline as a result of programs already underway. As a result, emissions in the year 2000 are expected to decrease to 150 MMTce. A global warming potentials (GWP) of 22 was used to convert methane emissions into a carbon dioxide equivalent. (Methane is roughly 22 times more effective at trapping heat in the atmosphere than carbon dioxide over a 100-year time horizon, considering both its direct and indirect effects.) This carbon dioxide equivalent was then expressed in carbon-equivalent terms.

Table 14. Methane Emissions Estimates for the Administration Baseline, 1990-2000

\begin{tabular}{|c|c|c|c|c|c|c|c|}
\hline Yoar & 1990 & 1995 & 1996 & 1997 & 1998 & 1999 & 2000 \\
\hline $\begin{array}{l}\text { Eotimated Mothane Emisaions } \\
\text { (million motric tons carbon equivalent) }\end{array}$ & 166 & 177 & 176 & 177 & 154 & 153 & 150 \\
\hline
\end{tabular}




\section{The Climate Change Action Plan: Technical Supplement}

The methane baseline contains emissions estimates for all known anthropogenic sources of methane emissions:

- Landfills

- Coal mining

- Natural gas systems

- Petroleum

- Fuel combustion

- Ruminants

- Livestock manure

- Rice.

Baseline methane emissions estimates for 1990 were taken from EPA's Report to Congress, Anthropogenic Methane Emissions in the United States, Estimates for 1990. In developing the estimates contained in its Report to Congress, EPA developed models that incorporate the latest and best information available on emissions from all the major anthropogenic methane emissions sources. The report was reviewed by DOE, USDA, the Office of Management and Budget, and outside experts before publication. It is available from EPA's Global Change Division at (202) 233-9110.

The EPA report also includes emissions projections for 2000 , which form the basis for the year 2000 methane baseline in the Plan. Some of the projections contained in the Report to Congress were changed slightly to reflect energy data that became available after its finalization. In addition, the year 2000 baseline incorporates the emissions reductions associated with existing actions and programs, at pre-Plan funding levels. In particular, the year 2000 Administration Baseline includes the following reductions:

- Reductions from implementation of the landfill gas rule to reduce emissions of non-methane organic compounds at the medium stringency level under consideration at EPA at the time the Administration Baseline was under development. Methane capture is an ancillary benefit of these regulations. (The Plan itself includes the incremental emissions reductions projected from implementation of a more stringent standard. EPA expects a final rule to be issued in summer 1994.)

- Reductions anticipated from implementation of State regulations designed to address uncertainty regarding split-estate ownership of coalbed methane in Virginia, and from implementation of similar Federal measures in other States as called for under EPACT.

- Reductions from implementation of EPA's Natural Gas Star program at the pre-Plan funding level (approximately 5 percent of total emissions from natural gas systems). Natural Gas Star is a voluntary program with companies in the natural gas supply system to reduce leakages.

- Reductions from implementation of EPA's AgStar program at the pre-Plan funding level (approximately 5 percent of total emissions from livestock manure). This program promotes capture and use of methane from waste management systems in livestock farming. 


\section{Nitrous Oxide Baseline Assumptions}

The Administration Baseline for $\mathrm{N}_{2} \mathrm{O}$ (Table 15) includes estimates for anthropogenic emissions resulting from fertilizer use, adipic acid production, and combustion of fossil fuels. A GWP value of 270 was used to convert $\mathrm{N}_{2} \mathrm{O}$ emissions into a carbon dioxide equivalent, which in turn was converted to a carbon equivalent.

Table 15. Nitrous Oxide Emisslons Estimates for the Administration Baseline, 1980-2000

\begin{tabular}{|c|c|c|c|c|c|c|c|}
\hline Year & 1990 & 1995 & 1996 & 1997 & 1998 & 1999 & 2000 \\
\hline $\begin{array}{c}\text { Eatimatod N2O Emisalons } \\
\text { (million motric tons carbon oquivalont) }\end{array}$ & 39 & 40 & 35 & 35 & 36 & 36 & 36 \\
\hline
\end{tabular}

\section{Fertilizer Use}

Emissions from fertilizer use for 1990 and 2000 were based on field data and models developed by the USDA, accounting for both primary and secondary flows of nitrogen through the environment.

\section{Adipic Acld}

Emisaions from adipic acid (nylon) production for 1990 and 2000 are based on a model developed for EPA that relates production with emissions, and on data supplied by industry. The Administration Baseline includes reductions in $\mathrm{N}_{2} \mathrm{O}$ emissions from controls now or soon to be in place at adipic acid production facilities.

\section{Fossill Fuel Combustion}

Emissions from mobile combustion for 1990 and 2000 are based on an EPA model that relates vehicle miles traveled and the distribution of control technology in each vehicle model year to $\mathrm{N}_{2} \mathrm{O}$ emissions factors.

More information on baseline emissions estimates for $\mathrm{N}_{2} \mathrm{O}$ from adipic acid production and mobile combustion can bo found in EIA's Emissions of Greenhouse Gases in the United States 1985-1990 (DOE/EIA-0573, September 1993) and in EPA's Estimation of Greenhouse Gas Emissions and Sinks for the United States 1990, which will be published in final form in early 1994.

\section{Hydrofluorocarbons and Perfluorocarbons Baseline}

Emissions of HFCs and PFCs were expected to increase from 20 MMTce in 1990 to 45 MMTce in 2000 in the Administration Baseline (Table 16). The emissions estimates include all known sources of these gases. Sources include byproduct emissions (primarily $\mathrm{HFC}-23, \mathrm{CF}_{4}$, and $\mathrm{C}_{2} \mathrm{~F}_{6}$ ) and emissions from manufacture and use of HFCs and PFCs as substitutes for chlorofluorocarbons (CFCs) and hydrogenated chlorofluorocarbons (HCFCs), and for other uses.

Table 16. HFC and PFC Emissions Estimates for the Adminlstration Baseline, 1990-2000

\begin{tabular}{|c|r|r|r|r|r|r|r||}
\hline Yaar & 1990 & 1095 & 1096 & 1997 & 1998 & 1900 & 2000 \\
\hline $\begin{array}{c}\text { Estimstod HFC and PFC Emisalon: } \\
\text { (million motric tons carbon oquivalent) }\end{array}$ & 20 & 30 & 34 & 37 & 40 & 43 & 46 \\
\hline
\end{tabular}


GWPs were used to place all greenhouse gas emissions on equivalent scales. The GWP of HFCs and PFCs ranges from 150 to 10,000 times that of carbon dioxide on a 100-year time horizon. Table 17 lists the GWPs used for the Climate Change Action Plan.

Emiseions estimates for the HFCs and PFCs that are now or will be used as substitutes for CFCs and HCFCs, for both 1990 and 2000, were based on an EPA vintaging model that takes into account the emisaions rates from equipment in which these substances are used; EPA recycling and other regulations that impact their use, and other factors. Baseline emissions estimates for HFC-23, which is produced as a byproduct of HCFC-22 production, were developed from data supplied by industry. Baseline estimates for 1990 and 2000 of $\mathrm{CF}_{4}$ and $\mathrm{C}_{2} \mathrm{~F}_{6}$ were derived from data supplied by industry as well as a literature review.

In 1990, HFCs and PFCs were not used widely as commercial chemicals. However, HFC-23 was released as a byproduct of HCFC-22 production, with estimated emissions of 2 to 4 percent of the HCFC-22 production level. $\mathrm{CF}_{4}$ and $\mathrm{C}_{2} \mathrm{~F}_{8}$ were released as byproducts of aluminum smelting. All three of these compounds are very long-lived gases with high, if still uncertain, GWPs.

HFCs are used primarily as replacements for the ozone-depleting CFCs and HCFCs, which are being phased out under the Montreal Protocol and Clean Air Act Amendments of 1990. HFCs are being evaluated and introduced on the market as refrigerants, solvents, fire extinguishing agents, sterilizers, and foam-blowing agents.

Looking toward the future, commercial markets are being explored for HFC-23 as a halon replacement and a specialized refrigerant. Even after the phaseout of HCFC-22 to protect the ozone layer, production of HCFC-22 as a polymer precursor will continue; therefore, there will still be emissions of HFC-23. The intentional uses of PFCs are expected to increase as they are introduced as alternatives to CFCs and HCFCs and additives in foam insulation processes.

The attached list of atmospheric lifetimes and estimated GWPs is taken from the 1992 report of the Intergovernmental Panel on Climate Change (IPCC) and a 1993 Science article by Susan Solomon. For chemicals without GWPs, surrogate estimates are based on comparable measured or expected atmospheric lifetimes.

\section{Baseline Emissions Estimates}

Table 17 provides preliminary estimates of HFC and PFC emissions for 1990 and 2000 . These estimates explicitly account for the timing of the release of HFCs and PFCs from the products and processes in which they are used. During the White House Conference on Climate Change, the DuPont Company provided an emission estimate of 44 MMTce in 2000 for HFCs alone, based on their own market projections. The Dupont estimates do not account for lags in atmospheric release.

Table 17. Prellminary Basellne Estimates for HFCs and PFCs

\begin{tabular}{|c|c|c|c|c|}
\hline \multirow[b]{2}{*}{ Chomionl } & \multirow[b]{2}{*}{ GWP } & \multirow{2}{*}{$\begin{array}{c}\text { Atmospherio Llie } \\
\text { (years) }\end{array}$} & \multicolumn{2}{|c|}{ Carbon Equivabent (MMM) } \\
\hline & & & 1090 & 2000 \\
\hline HFCs & $150-10,000$ & 2.280 & $\sim 16$ & -40 \\
\hline$P F C_{3}\left(C F_{1}, C_{2} F_{2}\right)$ & $5,000 / 10,000$ & $>10,000$ & $\sim 4$ & $\sim 5$ \\
\hline Total & & & -20 & -46 \\
\hline
\end{tabular}




\section{Mothodology for HFC and PFC Emisslons Estimates}

The Administration Baseline estimates cited above for HFCs and PFCs were developed by EPA based on:

1. Vintaging model results related to the stock of equipment in each end use, chemical use per piece of equipment, equipment lifetimes, and emission rates from each piece of equipment.

2. Subatitution scenarios that describe the chemicals that will replace CFCs, halons, and HCFCs when they are phased out under the Copenhagen Amendments to the Montreal Protocol. The scenarios are baesed on estimated market penetration and the number of years it may take to fully implement a substitute.

The following key assumptions were made:

1. HFC-23 was assumed to be emitted as a byproduct of HCFC-22 production. Its emission rate was assumed to be 2 to 4 percent of total captive and noncaptive HCFC-22 production.

2. HFCs were assumed to be recycled after 1995 in all refrigeration, air conditioning, and halon end uses. For the refrigeration sector, the recycling rates were assumed to be the same as those for CFCs and HCFCs.

3. The average leak rate for chillers was assumed to be approximately 5 percent per year (down from the current rate of 10 to 15 percent).

4. A range of emission estimates was used for automobile air conditioners, based on the assumption that they require between 0.16 to 0.19 kilograms of HFC-134a per year to maintain their operation. This analysis shows the estimate for $0.16 \mathrm{~kg}$ per year per vehicle.

5. The 1990 estimate for HFC-152a was attributed to its use as a component of a refrigerant blend (RE00) used historically in dehumidifiers.

6. GWPs for HFC-227ea, HFC-356, HFC-S (a proposed HFC solvent with a 50- to 70-year life), and for some of the PFCs have not yet been estimated. The GWPs used for this analysis were estimates based on known GWPs.

7. The analysis did not include any impact (positive or negative) of the chosen alternative on the energy efficiency of the system or product.

8. Emisaions estimates for the $\mathrm{PFCs}, \mathrm{CF}_{4}$, and $\mathrm{C}_{2} \mathrm{~F}_{6}$ were based on emission factors for the $0.6 \mathrm{~kg} \mathrm{CF}_{4}$ and $0.06 \mathrm{~kg} \mathrm{C}_{2} \mathrm{~F}_{\text {}}$ per metric ton of aluminum produced.

The key uncertainties are:

1. The chosen alternatives, the substitution rate, the market penetration, and years to maximum penetration of chemicals that in some cases are not yet even on the market.

2. Loak rates and recycling rates for new equipment, which in this case were based on expected system improvements.

8. The total percentage of HFC-23 from HCFC-22 production and the estimated market for HCFC-22. Original estimates were 2 percent, but they were revised to be as high as 4 percent.

4. Emisaion factors for $\mathrm{CF}_{4}$ and $\mathrm{C}_{2} \mathrm{~F}_{6}$.

5. The GWPs for chemicals for which there are no direct measurements. 


\section{Carbon Sequestration Baseline}

The baseline for carbon sequestration in the forest system was developed using two USDA Forest Service models: the Aggregate Timberland Assessment System (ATLAS) biologic model coupled with the Timber Assessment Market Model (TAMM)-an economic model. The TAMM/ATLAS system has been used extensively by the USDA Forest Service and others for analysis of the impacts of changes in forest policies in the United States. Based on this modeling system and recently announced changes in National Forest harvest levels, the Administration Baseline projects that annual carbon sequestration from forested lands in the United States will increase from 130 MMT in 1990 to 137 MMT in 2000.

The model starts with an inventory of timber in the United States as of 1987. Growth (yield) functions for various forest management regimes are used to add volume to the inventory, and simultaneously, volume is reduced though harvests. Harvests are the result of exogenous assumptions for public lands and computed demands on inventories on private lands. Demands on private lands are computed by an econometric model that is driven largely by assumptions about gross domestic product, population, and the level of wood use in various product applications, such as the number of housing starts. The biologic and economic models are linked through stumpage (standing timber) markets. All trade is exogenous with the exception of softwood lumber imports from Canada, which are responsive to changes in U.S. prices for softwood lumber. A total for U.S. timber inventory is computed over time and converted to carbon through the use of two carbon accounting models: the Forest Carbon (FORCARB) model, maintained by USDA Forest Service, and the Forest Carbon Model (FCM), maintained by EPA.

The veraion of TAMM/ATLAS used in this analysis was also used by the Forest Service for the 1989 Resources Planning Act (RPA) Assessment (General Technical Report RM-199). In the spring of 1992 , the assumption about Federal harvest in the model was revised downward to reflect the Dwyer injunction and other conditions at that time. The projections included reductions in pulpwood demand consistent with increases in the use of recycled fiber in the papermaking process. Inventory estimates for 1990 were developed by interpolating between the 1987 data and the projections for the year 2000. Inventories at the decadal points were run through the two carbon models. The changes in carbon inventories between decadal points were calculated from each model's results and then averaged. Annual estimates were calculated from the decadal changes.

The additional carbon savings attributed to changes in National Forest harvests by the Clinton Administration were estimated by extrapolating from differences in carbon inventories between the 1989 RPA model version projections and the updated 1992 model version projections (per billion cubic foot harvest reduction), for which the only difference is the level of Federal harvest. Annual carbon savings were calculated and added to the baseline. Carbon savings attributed to a shift to ecosystem management in National Forests were estimated by assuming a fixed percent savings in total ecosystem carbon at harvest and adding that to the baseline. The fixed percent was estimated from expert judgments of various individuals in the Forest Service.

Supplies and demands in the TAMM model are based on econometric relationships differentiated by region and estimated with data series going back to the 1950s. Solution of the model is based on minimization of costs in a linear programming format. Gross national product, population, and other macroeconomic assumptions draw largely from projections made for the USDA Forest Service and the USDA Soll Conservation Service by Wharton Econometrics (General Technical Report RM-174). In these projuctions, population grows from 241.6 million people in 1986 to 274.9 million in 2000, and gross national product increases from $\$ 3.7$ trillion in 1986 to $\$ 5.4$ trillion in 2000 . Technical and other exogenous assumptions for the model were based on expert judgment of various individuals in the Forest Service. These assumptions have received wide review and are revised as new information becomes available. Included in the baseline projection is the assumption of increased recycling (to 45 percent) and the net effects of a 500-million-cubic-foot reduction in harvest on National Forest lands. Expert judgment assumed a 10-percent savings of ecosystem carbon due to ecosystem management. 
Changes in U.S. timber inventories as depicted through TAMM and ATLAS and the effects of increased recycling and reduced harvest resulted in a baseline projection of 130 million metric tons per year from 1990 through 2000. By the year 2000, an additional reduction of 700 million cubic feet in harvest from National Forests (4 to 5 million metric tons per year) and a shift to ecosystem management in National Forests (2 to 3 million metric tons per year) were assumed, raising the baseline total in 2000 to 137 million metric tons per year (Table 18). These additions to the baseline were attributed to Clinton Administration policies.

Table 18. Forestry Carbon Sequestration Estimates for the Adminlstration Basellne, 1990-2000

\begin{tabular}{|c|c|c|c|c|c|c|c|}
\hline Yoar & 1990 & 1995 & 1996 & 1997 & 1998 & 1999 & 2000 \\
\hline $\begin{array}{c}\text { Eatimated Carbon Soquestered } \\
\text { (million motric tons) }\end{array}$ & 130 & 132 & 133 & 134 & 135 & 136 & 137 \\
\hline
\end{tabular}


This chapter provides detailed information on each of the actions in the Climate Change Action Plan (the Plan). The following information is presented:

- For each action, an Action Description (brief narrative description of the action), an Analysis Description (methodology used for stand-alone analysis), and Input Assumptions (inputs for the analysis associated with that action). Annual estimated Feders! expenditures to implement each individual action are presented in tabular form following each group of actions.

- For each set of closely related actions, a table of annual estimated private investment. It is often impossible to attribute private investment to individual actions, because enterprises and households may be participating in more than one program to promote similar types of energy-efficiency improvements.

- For each energy end-use sector, a table of annual carbon emissions and energy use impacts of the Plan actions. Again, interactive effects make it extremely difficult, if not impossible, to attribute such impacts to individual actions or subgroups of actions.

- For all gases except carbon emissions from the energy sector, year-by-year estimates of emissions reductions are also presented. For energy-related carbon emissions, the year-by-year profile is contained in Chapter 4, which presents an integrated analysis of these actions. Because of interactive effects, the combined impact of energy-related actions cannot be determined by simple summation.

\section{Commercial Actions}

\section{(1) Coordinate DOE Rebuild America and EPA Energy Star Buildings}

Action Description: The U.S. Environmental Protection Agency (EPA) and the U.S. Department of Energy (DOE) will coordinate the expansion of the EPA Energy Star Buildings program and the DOE Rebuild America program. Participants in the Energy Star Buildings program will be required to:

- Survey their domestic facilities

- Upgrade their heating, ventilation, and air conditioning (HVAC) systems where profitable

- Complete their buildings upgrades within 7 years.

EPA will use marketing and program implementation resources developed for the Green Lights and Energy Star Buildings programs to expand participation. EPA will also expand "Ally" programs, through which partnerships are formed with manufacturers, utilities, distributors, surveyors, energy service companies, architects, and engineers.

Rebuild America is a new DOE initiative that will incorporate extensive demonstrations, training, education, performance monitoring, and cost-shared energy audits. DOE will use the 10 regional building efficiency centers established under the Energy Policy Act of 1992 (EPACT).

Analysis Description: EPA and DOE staff working in the Commercial Energy Demand Subgroup derived percent energy savings and market penetration figures for these commercial buildings programs. Estimates of energy savings were derived from a combination of building simulation computer modeling, literature review of technology developments, discussions with industry experts, and review of published case studies. Market penetration estimates were derived from projections of Green Lights program participation, assuming that two-thirds of those participants will ultimately join the Energy Star Buildings program. Rebuild America contributed additional market penetration. 
Input Assumptions: EPA and DOE derived percent end-use energy savings figures for input to the IDEAS model. The parameters translated the savings expected from comprehensive, whole-building efinciency upgrades into end-use energy savings. Hence, the efficiency gains are somewhat higher than expected from end-use equipment improvements alone. It was estimated that the coordinated programs would achieve upgrades in 6 percent of the floorspace in the existing buildings stock by 2000 . The percent end-use energy savings were as follows: electric space heat-50 percent; gas/oil space heat-35 percent; electric cooling -50 percent; thermal end uses (i.e., water heating, cooking, and drying) -30 percent.

\section{(2) Expand EPA's Green Lights Program}

Action Description: EPA will pursue new or significantly expanded Green Lights initiatives. Launched in January 1991, the EPA Green Lights program is a voluntary, nonregulatory program designed to reduce pollution through the initiative of organizations across the country. All Green Lights participants sign a "Memorandum of Understanding" with EPA, agreeing to (1) survey all their domestic facilities, (2) upgrade their lighting where profitable, and (3) complete their lighting upgrades within 5 years. An upgrade is deemed profitable if it shows an internal rate of return exceeding the prime rate plus six points (i.e., roughly 12 to 13 percent as of late 1993). EPA supports Green Lights participants with a peckage of tools designed to ensure that lighting upgrades will save energy and obtain the highest possible return on investment. A team of lighting experts provides Green Lights participants with tochnical support and problem-solving advice through a technical hotline, a comprehensive manual, regional training workshops, up-to-date literature, and on-site implementation visits. Additionally, Green Lights "Allies" programs for lighting manufacturers, lighting management companies, and electric utilities extend the Green Lights partnership by enlisting the support of the lighting and power industries.

Analysir Description: EPA and DOE staff working in the Commercial Energy Demand Subgroup derived percent energy savings and market penetration figures for the Green Lights program. Estimates of energy savings were derived from review of completed Green Lights upgrades, engineering analysis, EPA and DOE technical reports, and literature review. Market penetration estimates were projected using the experience of Green Lights Partner recruiting. The effects of electric utility lighting demandside management (DSM) programs were explicitly accounted for in the Green Lights energy sevings estimates.

Input Asoumptions: IPA and DOE derived lighting energy savings parameters for input to the IDEAS model. The savings numbers reflect a comprehensive systems approach to lighting savings. It was estimated that with expanded activities Green Lights would achieve upgrades in an additional (i.e., over and above the existing Green Lights program) 11 percent of the floorspace in commercial and industrial buildings by 2000. The percent lighting energy savings due to these upgrades were as follows: Green Lights Partners that obtain utility rebates-60 percent; Green Lights Partners not obtaining utility rebateo -55 percent; upgrades completed through Super Ally utility programs -55 percent; and upgrades supported by Distributor Allies-35 percent.

\section{(3) Establish State Revolving Fund for Public Bulldings}

Action Description: This initiative would competitively select 10 States per year to award \$1 million per State as seed funding to set up energy efficiency revolving loar funds for State and local buildings. The funds, once established, make loans to various State and local agencies to perform energy efficient improvements. The loans are then paid back in future years from the energy savings that occur, and are available to be loaned again. This strategy leverages the Federal investment for improving efficiency in State and local buildings, because the funds are loaned and repaid many times over.

Analyais Deweription: The interagency team modeled energy-use intensities by energy end use and building type. Each building type was divided by size (large and small) and by ownership (rented, owner cccupied, multiple occupant, government). For each building type and end use, the modeling team developed estimates of the market penetration rate of new technologies and the energy savings from those technologies relative to the baseline. The market penetration rate and energy savings estimates together determine energy savings and greenhouse gas reductions. 
Input Assumptions: Compared to the baseline technology assumptions, the average energy savings from the application of new technologies, aggregated over all building types and end uses, was 29 percent. The onergy savings in specific end uses are as follows: space heating, cooling, thermal, and refrigeration-35 percent; and miscellaneous electric-10 percent. In 2000, 2 percent of all buildings (10 percent of State/local buildings) are assumed to use new technologies as a result of this action.

\section{(4) Expand Cost-Shared Demonstration of Emerging Technologies}

Action Description: Together with building owners and product manufacturers, DOE will deploy fullscale applications of new technologies and practices in Federal, State and local, or private buildings. The demonstrations will allow manufacturers to acquire field experience that will lower the perceived risk of using the technologies and accelerate commercialization. The program will be administered by DOE, and proposals will be solicited from private industry, States, and Federal agencies to demonstrate technologies that are close " "sarket ready." Proposals will be evaluated on the basis of technical merit, level of cofunding by manc dcturers and host agencies, State and local government involvement, and information dissemination benefits.

Analyois Description: The interagency team modeled energy-use intensities by energy end use and building type. Each building type was divided by size (large and small) and by ownership (rented, owner occupied, multiple occupant, government). For each building type and end use, the modeling team developed estimates of the market penetration rate of new technologies and the percent energy savings from those technologies relative to the baseline. The market penetration rate and energy savings estimates together determine energy savings and greenhouse gas reductions. This action was modeled jointly with action (5), described below.

Input Assumptions: Because this action and action (5) work together, a single set of parameters was used to represent the market penetration rate of new technologies and the energy savings from applying those technologies. Table 19 shows the key assumptions. The market penetration figure shows the percent of commercial floorspace (existing and new) that will have adopted one of the listed technologies as a result of these actions. These market penetration percentages are over and above the natural rate of adoption for new technologies. For example, Table 19 shows that in existing floorspace, as a result of these actions, an additional 4 percent of the floorspace in 2000 will use advanced space heating technologies. The energy savings for advanced space heating are 33 percent relative to the baseline technology.

Table 19. Market Penetration Rates and Energy Saving for Actlons (4) and (5), Year 2000

\begin{tabular}{|c|c|c|}
\hline Mosesure & Porcent of Exloting Floorapace & Porcent of Now Floorepace \\
\hline \multicolumn{3}{|l|}{ Market Penotration } \\
\hline Spaco Heat & 4.0 & 17.9 \\
\hline Cooling & 3.6 & 15.7 \\
\hline Thermal & 4.6 & 20.4 \\
\hline Miscollaneous Electric & 3.7 & 16.3 \\
\hline \multicolumn{3}{|l|}{$\begin{array}{l}\text { Enerey Savings Rolative } \\
\text { to Bacolline Tochnology }\end{array}$} \\
\hline Speces Hoet & 33.0 & 29.0 \\
\hline Cooling & 31.0 & 28.0 \\
\hline Thermat & 27.0 & 24.0 \\
\hline Miecollaneous Electric & 11.0 & 10.0 \\
\hline
\end{tabular}




\section{(5) Establish Energy Efficlency and Renewable Energy Information and Training Programs}

Action Description: This initiative is designed to facilitate better energy-related decisions by facility managers, homeowners, architects and engineers, code officials, and others. DOE will work with groups and organizations, such as the National Advertising Council, industry associations, State energy offices, technology manufacturers, public interest groups, and universities. Activities will include: gathering and developing targeted training materials and information materials; providing technical and/or financial assistance for training programs; assisting in the design and implementation of a certification program for facility managers; distributing information through existing State and field networks; verifying savings and promoting building commissioning; and launching a media campaign to measure public and decisionmaker awareness of energy efficiency and renewable energy technologies.

Analysis Description: The interagency team modeled energy-use intensities by energy end use and building type. Each building type was divided by size (large and small) and by ownership (rented, owner occupied, multiple occupant, government). For each building type and end use, the modeling team developed estimates of the market penetration rate of new technologies and the percent energy savings from those technologies relative to the baseline. The market penetration rate and energy savings estimates together determine energy savings and greenhouse gas reductions.

Input Assumptions: See action (4).

\section{Commercial Actions Summary}

Between 1994 and 2000, commercial energy efficiency actions in the Plan will reduce carbon emissions by almost 33 million metric tons (MMT) and save 1.5 quadrillion Btu of energy (Table 20). This will require $\$ 445$ million in Federal outlays and about $\$ 20.5$ billion in private investment.

\section{Residential Actions}

\section{(6) Form Golden Carrot Market-Pull Partnerships}

Action Description: The President has instructed DOE and EPA to launch partnerships through the Consortium for Energy Efficiency (CEE) to commercialize advanced, energy-efficient residential appliances and equipment. Golden Carrot partnerships can range from "winner-take-all" contests, like the Super Efficient Refrigerator Program, to "come-one-and-all" programs, in which utilities pay incentives for any manufacturer's products that achieve high performance levels. These utility initiatives will be combined with efforts to influence government or publicly assisted procurements, as well as with Federal efforts to improve the delivery of energy-efficient mortgages (EEMB) and home energy rating systems (HERSs).

Analysis Description: Opportunities for significant increases in energy efficiency exist in many residential end uses. Major end uses and appliances, including heating and cooling equipment, water heating equipment, washers, dryers, ductwork, lighting, windows, and insulation were reviewed. Energy end-use baselines were derived from the extensive data collected at Lawrence Berkeley Laboratories for its Residential End-User Energy Planning System (REEPS) model. For each end use, the analytical team then identified emerging or existing but underutilized technologies that have a potential for reducing energy usage cost-effectively.

Input Assumptions: For each technology, realistic estimates were derived for energy-efficiency improvements and market penetration that would likely result from Golden Carrot programs (Table 21). The market penetration estimates show the additional market penetration caused by this action over and above the baseline penetration rate. Penetration estimates were very modest at the onset of the programs starting in 1995 or 1996, increasing gradually each year through 2000. 
Table 20. Commerclal Energy Efficlency Actions

\begin{tabular}{|c|c|c|c|c|c|c|c|c|}
\hline Action & FY 1094 & FY 1095 & FY 1800 & FY 1907 & FY 1908 & FY 1980 & FY 2000 & $\begin{array}{c}\text { FY } 1904-2000 \\
\text { Total }\end{array}$ \\
\hline \multicolumn{9}{|c|}{ Fodoral Outlays (million dollars) } \\
\hline (1) & $\$ 5$ & $\$ 27$ & $\$ 34$ & $\$ 35$ & $\$ 35$ & $\$ 29$ & $\$ 27$ & $\$ 190$ \\
\hline (2) & $\$ 8$ & $\$ 14$ & $\$ 15$ & $\$ 15$ & $\$ 15$ & $\$ 15$ & $\$ 15$ & $\$ 90$ \\
\hline (3) & so & $\$ 11$ & $\$ 11$ & $\$ 11$ & $\$ 11$ & $\$ 11$ & $\$ 0$ & $\$ 55$ \\
\hline (4) & \$o & $\$ 10$ & $\$ 10$ & $\$ 10$ & $\$ 10$ & $\$ 10$ & $\$ 10$ & $\$ 60$ \\
\hline (5) & so & $\$ 7$ & $\$ 7$ & $\$ 7$ & $\$ 7$ & $\$ 7$ & $\$ 7$ & $\$ 42$ \\
\hline Total & $\$ 12$ & $\$ 69$ & $\$ 77$ & $\$ 78$ & $\$ 78$ & $\$ 72$ & $\$ 50$ & $\$ 445$ \\
\hline \multicolumn{9}{|c|}{ Privato Investment (million dollars) } \\
\hline (1) & $\$ 440$ & $\$ 630$ & $\$ 880$ & $\$ 880$ & $\$ 880$ & $\$ 1,200$ & $\$ 1,400$ & $\$ 6,300$ \\
\hline (2) & $\$ 230$ & $\$ 330$ & $\$ 460$ & $\$ 460$ & $\$ 460$ & $\$ 630$ & $\$ 730$ & $\$ 0,300$ \\
\hline (3) & $\$ 180$ & $\$ 250$ & $\$ 350$ & $\$ 350$ & $\$ 350$ & $\$ 480$ & $\$ 550$ & $\$ 2,500$ \\
\hline$(4+5)$ & $\$ 560$ & $\$ 840$ & $\$ 1,200$ & $\$ 1,200$ & $\$ 1,200$ & $\$ 1,600$ & $\$ 1,800$ & $\$ 8,400$ \\
\hline Total & $\$ 1,400$ & $\$ 2,100$ & $\$ 2,900$ & $\$ 2,900$ & $\$ 2,900$ & $\$ 3,900$ & $\$ 4,500$ & $\$ 20,500$ \\
\hline \multicolumn{9}{|c|}{ Annual Greenhouse Gas (GHG) Reduction and Energy Savings } \\
\hline $\begin{array}{l}\text { GHG Reduction } \\
\text { (MMTce) }\end{array}$ & $n / a$ & 1.1 & 2.3 & 4.0 & 6.3 & 8.5 & 10.6 & 32.8 \\
\hline $\begin{array}{l}\text { Energy Savings } \\
\text { (quadrillion Btu) }\end{array}$ & $n / a$ & 0.1 & 0.1 & 0.2 & 0.3 & 0.4 & 0.5 & 1.5 \\
\hline
\end{tabular}

Notes: Totals may not equal sum of components due to independent rounding. The budget authority numbers shown in this table reflect the requests made by the various agencies for project funding at the time the Plan was announced; they do not necessarily indicate the actual appropriation of funds.

Energy savings estimates reflect available or emerging technology options, tempered by interaction between measures, DOE standards, and the existing baseline trajectory of efficiency improvement. Building envelope (windows and insulation) improvements were lowered in order to prevent double counting. However, the interactive effects between implementation of building shell improvements and equipment improvements were included in the analysis.

\section{(7) Enhance Residentlal Appliance Standards}

Action Description: The Energy Policy and Conservation Act (Public Law 94-163), as amended by various statutes including the National Appliance Energy Conservation Act and the Energy Policy Act of 1992, directs the Department of Energy to develop mandatory energy efficiency standards for residential and commercial appliances and equipment.

The legislation establishes energy efficiency standards for major energy-using residential appliances and directs DOE to review these standards in accordance with a statutory schedule to determine whether they should be made more stringent. The statutory guideline is that the standards should achieve the maximum energy savings that are technologically feasible and economically justified. The energy efficiency improvements and emissions projections associated with this action assume that the records developed in energy efficiency rulemakings will support the adoption of more stringent standards. 
Table 21. Market Penetration Rates and Energy Savings for Action (6), Year 2000

\begin{tabular}{|c|c|c|}
\hline Tochnology & $\begin{array}{l}\text { Porcent of Salos Applying } \\
\text { Technology Due to Action }\end{array}$ & $\begin{array}{c}\text { Percent Energy Savinge Rolative to } \\
\text { Baseline Technology }\end{array}$ \\
\hline $\begin{array}{l}\text { Wetor Hoators } \\
\text { Hoat Pump } \\
\text { Advancod Gas }\end{array}$ & $\begin{array}{l}14 \% \\
20 \% \\
\end{array}$ & $\begin{array}{l}\mathbf{5 3} \% \\
\mathbf{3 3} \% \\
\end{array}$ \\
\hline Low Flow Showerhoads & $20 \%$ & $28 \%$ \\
\hline Weshers & $24 \%$ & $10 \%$ \\
\hline $\begin{array}{l}\text { Dryors } \\
\text { Electric } \\
\text { Gas }\end{array}$ & $\begin{array}{l}20 \% \\
20 \%\end{array}$ & $\begin{array}{l}65 \% \\
37 \%\end{array}$ \\
\hline Residontial Lighting & $6 \%$ & $33 \%$ \\
\hline $\begin{array}{l}\text { Air Conditioners } \\
\text { Central } \\
\text { Room }\end{array}$ & $\begin{array}{l}24 \% \\
30 \% \\
\end{array}$ & $\begin{array}{l}33 \% \\
31 \% \\
\end{array}$ \\
\hline $\begin{array}{l}\text { Heat Pumps } \\
\text { Electric (advancod) } \\
\text { Gas }\end{array}$ & $\begin{array}{l}15 \% \\
8 \%\end{array}$ & $\begin{array}{l}52 \% \\
29 \% \\
\end{array}$ \\
\hline Advanced Gas Furnace & $20 \%$ & $20 \%$ \\
\hline
\end{tabular}

DOE has already issued advance notices soliciting initial public input on two appliance rulemakings, which are expected to take effect before 2000. The first rulemaking will cover eight producto-room air conditioners, water heaters, direct heating equipment, mobile home furnaces, kitchen ranges and ovens, pool heaters, television sets, and fluorescent lamp ballasts. DOE is expected to issue a Notice of Proposed Rulemaking (NOPR) in early 1994 and a final rule about a year later. The new standards will take effect 3 years later. The second rulemaking will cover three products-central air conditioners, furnaces, and refrigerators. The issuance of the final rule for these products is expected in 1996, leading to new standards in 1999.

Analysis Description: The baseline energy use in the residential sector was estimated using the IDEAS model. The IDEAS model disaggregates energy use into space heating (by gas, oil, and electricity), cooling (electricity), thermal (including water heating, cooking, and drying by gas, oil, and electricity), refrigeration, lighting, and other appliances. The Lawrence Berkeley Laboratory REEPS model was used to further disaggregate the projected energy use of the 11 products in these two rulemakings.

Input Assumptions: Each of the covered products was disaggregated into appropriate classes, based on their energy source, size, and consumer utility. An engineering cost curve was developed for each product class, reflecting the estimated increased first cost and future energy savings of incremental technology improvements, starting at a baseline representing the currently required standard level and moving in steps to the limit of what is technologically feasible (Table 22).

Candidate standard levels were selected from these engineering cost curves. The economic justifiability of the different standard levels was assessed, including their first costs and energy savings to consumers. A discount rate of 6 percent was used in examining life-cycle costs, with sensitivity runs at the 4-percent and 10-percent levels.

The estimated energy and carbon savings assume that the highest standard levels that are technologically feasible and economically justified at the 6-percent discount rate will be selected as the standard levels in the eight-product rulemaking. For appliances covered by the eight-product rulemaking, 
Table 22. Example of Information Contained in an Engineering Cost Curve:

CFC-Free Top-Mount Auto Defrost Refrigerator-Freezer

\begin{tabular}{|c|l|c|c|c|c||}
\hline $\begin{array}{c}\text { Standard } \\
\text { Loval }\end{array}$ & \multicolumn{1}{|c|}{ Dealgn } & $\begin{array}{c}\text { Consumor } \\
\text { Price } \\
\text { (1887 dollars) }\end{array}$ & $\begin{array}{c}\text { Energy } \\
\text { Exponse } \\
\text { (1987 dollars) }\end{array}$ & $\begin{array}{c}\text { Payback } \\
\text { Poriod } \\
\text { (Incremontal) }\end{array}$ & $\begin{array}{c}\text { Payback } \\
\text { Porlod } \\
\text { (Cumulativo) }\end{array}$ \\
\hline & Baseline & 521.7 & 75.5 & NA & NA \\
\hline 0 & Design 0 + Enhanced Hoat Transfor & 521.9 & 74.0 & 0.2 & NA \\
\hline 1 & Design 1 + Foam Door & 525.1 & 69.4 & 0.7 & NA \\
\hline & Design 3 + 5.05 EER Compressor & 532.3 & 62.2 & 1.0 & 1.0 \\
\hline 2 & Design 4 + 2.0" Door Insulation & 540.6 & 60.3 & 4.4 & 1.7 \\
\hline & Design 6 + 2.6" Side Insulation & 577.0 & 55.8 & 8.5 & 3.8 \\
\hline 3 & Design 6 + 3.0" Side Insulation & 587.1 & 54.5 & 8.3 & 4.2 \\
\hline 4 & Design 6 + Evacuated Panels & 656.2 & 45.6 & 7.9 & 5.5 \\
\hline & Design 9 + Two-Compressor System & 760.7 & 40.2 & 19.2 & 8.1 \\
\hline 5 & Design 10 + Adaptive Defrost & 794.0 & 38.7 & 23.4 & 8.8 \\
\hline
\end{tabular}

energy savings are based on a product-by-product analysis of market penetration of new appliances and energy savings. For appliances covered by the three-product rulemaking, where analyses are not yet available, the energy savings estimates were based on experience with similar rulemakings.

Table 23 shows the assumed energy savings relative to baseline technologies for the standards included in this action. Because all new appliances will be required to meet a standard once it becomes effective, the market penetration rate for new sales after the effective date is 100 percent.

Table 23. Energy Savings from Enhanced Resldentlal Appllance Standards, Year 2000

\begin{tabular}{|l|c|c|}
\hline \multicolumn{1}{|c|}{ Appliance } & Yoar Standard is Effoctive & Porcent Enorgy Savings \\
\hline Water Heaters & 1998 & \\
Electric & 1998 & $56 \%$ \\
Gas & 1998 & $17 \%$ \\
Oil & & $30 \%$ \\
\hline Dryers & 1998 & \\
Electric & 1998 & $33 \%$ \\
Gas & & $9 \%$ \\
\hline Air Conditioners & 1998 & $31 \%$ \\
Room & 1999 & $31 \%$ \\
Contral & & \\
\hline Cooking & 1998 & $10 \%$ \\
Electric & 1998 & $10 \%$ \\
Gas & 1999 & $28 \%$ \\
\hline Refrigarators & 1998 & $42 \%$ \\
\hline Telovisions & & \\
\hline
\end{tabular}




\section{(8) Promote Home Energy Rating Systems and Energy-Efficlent Mortgages}

Action Description: DOE is sponsoring a Home Energy Rating Systems (HERS) Council, composed of all the major stakeholders in the housing and home financing fields, which will create a national HERS program. The program will establish uniform national criteria for home rating systems, a procedure for certifying HERS programs that meet the criteria, and quality control mechanisms to assure that the certified programs provide ratings that can be relied upon by home buyers and housing finance institutions. At the same time, DOE will work with the U.S. Department of Housing and Urban Development (HUD), the Department of Veterans Affairs (DVA), the Federal Housing Authority (FHA), the secondary mortgage market, and primary lenders to support a broader national program of energyefficient mortgages (EDMs), which recognize that the energy savings from efficient new and retrofitted housing will enable home buyers to afford larger mortgage payments. DOE also will support an agresaive marketing program to promote the energy, economic, and environmental benefits of participation in HERS and EEM programs, including efforts to encourage utilities to recognize this saved energy potential in their DSM programs. BPACT requires that HUD offer EEM mortgages on all new and existing FHA-insured housing starting October 24, 1994, which will provide a strong stimulus for this Action.

Analyoir Description: The number of homes purchased or refinanced was estimated at 5 million annually through 2000 . The percent of purchased or refinanced homes that participated in the program was combined with percent energy savings per participant to estimate overall energy savings and greenhouse gas reductions.

Input Asoumptions: Under the Plan, HERSs and EEMs are estimated to penetrate 20 percent of the home mortgage market for newly built homes and 20 percent of the market for resales by 2000. For existing houses (pre-1993), 2 percent of the total stock will have been affected by 2000 . The energy savinge per new construction participant depend on whether the home is located in a State with residential building standards. Building standards alone are assumed to reduce residential heating and cooling energy consumption by 25 percent. An EEM in a State with standards raises the percentage reduction in heating and cooling energy consumption to 45 percent (the marginal impact of the EEM is 20 percent); for States without standards, the EEM alone is expected to reduce heating and cooling energy consumption by 40 percent. For participating existing buildings, energy savings are assumed to be 30 percent.

\section{(9) Expand Cool Communitles Program in Cliles and Federal Facillties}

Action Description: The DOE Cool Communities initiative promotes the use of strategic landscaping to shade residential and commercial buildings, and of light-colored building surfaces to reduce absorption of sunlight. The program uses these proven technologies (1) to reduce cooling energy and related emissions and (2) to sequester carbon. The program aims to enlist 250 new cities (population 30,000 or over) and 100 Federal facilities as "Cool Communities" between 1995 and 2000, through a concerted technical assistance and education effort. In each city, the program will work with homeowners, businesses, and their communities and partners to proliferate strategic landscaping and light-colored surfacing as energy-conserving technologies. The initiative will enlist three corporations and one utility as partners in each city.

Analysis Description: Estimates were made of the regional availability of suitable housing units without trees, using data from the 1990 Census, the Energy Information Administration's Household Energy Consumption Survey, and MacPherson's report on a tree planting analysis of 12 U.S. cities."

7. Enory Information Administration, Howeehold Energy Consumption and Expenditures 1990: Residential Energy Consumption Survey, DOP/SLA-0321(90) (Washington, DC, Fob. 1993).

8. D.G. MacPhorson et al., Modeling Benefits and Costs of Community Tree Planting: A Demonstration Project, Final Report (Chicago, Il: USDA Forent Service, Northeactern Forest Experiment Station, 1993). 
Carbon uptake per tree was taken from yield tables by Nowak." Carbon sequestered is the product of the trees planted and the average uptake per tree per year. Tree planting and other costs by region were taken from MacPherson, ${ }^{10}$ and were multiplied by the number of trees per region. Enerey savings per tree per house were taken from MacPherson ${ }^{11}$ and multiplied by the number of houses. The energy savings from using light-colored building surfaces were not included in the calculations due, to lack of sufficiont data. Energy savings due to surface color changes are believed to further increase the savings from strategic planting.

Inprt Acumptions: It was assumed that one tree would be planted per house. The carbon sequentration rate averaged 34 pounds per year across all regions. Average tree planting costs ranged from $\$ 48$ to $\$ 137$ per tree, plus 50-year maintenance costs of $\$ 15$ to $\$ 183$ per tree, depending on the region. Trees were assumed to gain full energy savings capability when they reached 15 years of age, and savinge were assumed to grow linearly from the time of planting to that point. Ten percent of the trees were assumed to be planted in the first program year (1995) and 18 percent in each additional year (1996-2000). Energy savings in 2000 were 0.8 billion kilowatthours (kWh). Surface color changes were aseumed to add 5 to 10 percent to the cost of routine maintenance and new construction, but the energy savings from surface color changes were not counted.

\section{(10) Upgrade Residential Bullding Standards}

Action Deccription: DOE will provide encouragement and technical support to States to strengthen their residential building standards to meet or exceed the Model Energy Code of the Council of American Building Officials (CABO). EPACT requires States to review the feasibility of strengthening their codes to meet or exceed the CABO code and report the results to the Secretary of Energy by October 24, 1994. DOE also will recommend cost-effective increases in the energy efficiency of the CABO code, which, if adopted, will trigger a requirement that States review their codes to consider the feasibility of strengthening them further to meet the additional energy-saving requirements. The technical assistance will include analyses on a State-by-State basis of the economic and environmental benefits of energysaving building standards. Financial support will be provided to States that are committed to strengthening their codes and implementing them effectively.

Analyais Description: The number of new homes constructed in future years was estimated using the Lawrence Berkeley Laboratory REEPS model and IDEAS macroeconomic assumptions (see Chapter 2). The energy use per house, including a disaggregation of space heating and cooling end use, was estimated from the IDEAS model Administration Baseline. The total energy savings from this action were estimated by computing the percentage energy savings from applying upgraded standards to the number of new homes constructed.

Input Assumptions: The analysis assumed that the number of new homes constructed annually would grow from 1.41 million in 1993 to 1.67 million in 2000. The building standards were estimated to reduce by 25 percent the energy requirements for space heating and cooling. Three States have residential building codes that meet or exceed the current CABO Model Energy Code, and the number was estimated to increase to 40 States by 2000-an increase of 15 States over the projected number of States to adopt such codes without the DOE technical support program.

\section{(11) Create Energy Efflclency Programs and Housing Technology Centers}

Action Description: DOE is creating this program to increase recognition among home builders and home buyers of the value of energy efficiency and solar technologies. The program will provide recognition for home buyers who exceed the energy efficiency requirements of mandatory State building codes. It will

9. D.J. Nowak, “Atmospheric Carbon Reduction by Urban Trees," Journal of Environmental Management, in press (1994).

10. MacPherson et al., op. cit.

11. Ibid. 
also include an aggressive information and education program that markets the value of energy efficiency and solar energy, including reduced energy costs, more comfortable housing, higher quality of construction, and the satisfaction of reduced environmental impacts. To deliver this program, DOE will seek partnerships with the National Association of Home Builders and key State home builder associations. DOE and EPA will complement these educational efforts with a market mobilization program targeted at builders and their trade allies (realtors, assessors, mortgage lenders) to produce and market highly efficient new homes. This exemplary home builders recognition initiative will be closely coordinated with efforts to strengthen energy-efficient mortgages and deliver Golden Carrot market-pull programs for high-efficiency residential equipment.

Analysis Description: The future number of new homes constructed was estimated using the Lawrence Berkeley Laboratory REEPS model. Energy use per house, including a disaggregation of space heating and cooling end use, was estimated from the IDEAS model, adjusted to reflect the revised Administration Baseline. The total energy savings were estimated by combining information on the percentage energy savings from applying new technology and energy-efficient construction practices with estimates of the number of new homes built.

Input Assumptions: The new homes constructed under this program are expected to use less energy for all end uses through the promotion of energy-efficient heating and cooling appliances, as well as an energy-efficient building envelope. As in action (10), the assumed number of homes constructed annually grows from 1.41 million in 1993 to 1.57 million in 2000 .

The effect of this program was assumed to depend on whether the State where a home was built had standards that met or exceeded CABO standards. With CABO or better standards in effect, in 2000, 10 percent of the new homes would participate in this program, with average energy savings of 20 percent. Without CABO standards, 5 percent of the new homes would participate in the program, with average energy savings of 40 percent. DOE and EPA will coordinate pilot projects with selected home builders in various regions to collect more accurate data on how much energy savings can be expected on a regional basis.

\section{Residential Actlons Summary}

Between 1994 and 2000, residential energy efficiency actions in the Plan will reduce carbon emissions by almost $42 \mathrm{MMT}$ and save 2.0 quadrillion Btu of energy (Table 24). This will require almost $\$ 400$ million in Federal outlays and about $\$ 31.2$ billion in private investment.

\section{Industrial Actions}

\section{(12) Create a Motor Challenge Program}

Action Description: The Motor Challenge Program is a voluntary, industry-driven collaborative program aimed at galvanizing U.S. business and industry into action to better understand, apply, and target energy-efficient electric motor systems. Mrtor systems being targeted for this initiative currently account for two-thirds of U.S. industrial electricity consumption. This action will focus initially on industrial manufacturing facilities and municipal facilities. The improvement of electric motor system efficiency requires the system integration of technology and application options, including energy-efficient motors, adjustable-speed drives, and efficient motor-driven equipment (e.g., pumps, fans, compressors).

The Motor Challenge will foster broad-based industrial participation in information exchange and technology deployment activities, ensuring the development of successful electric motor system strategies and their replication within and across industries. Showcase demonstrations will highlight how industrial facilities can combine internal resources with technical assistance from DOE to improve their energy efficiency, productivity, and environmental performance by adopting efficient electric motor systems. The Motor Challenge will develop an electric motor system database to provide a consistent base of information for decisionmaking and to recognize industry's achievements in implementing efficient electric motor system strategies. 
Table 24. Fesldential Enorgy Efticlency Actlons

\begin{tabular}{|c|c|c|c|c|c|c|c|c|}
\hline Aotion & FY 1804 & FY 1908 & FY 1900 & FY 1097 & FY 1998 & FY 1900 & FY 2000 & $\begin{array}{c}\text { FY } 1094-2000 \\
\text { Tolal }\end{array}$ \\
\hline \multicolumn{9}{|c|}{ Podoral Outbye (million dollare) } \\
\hline (6) & $\$ 2$ & $\$ 24$ & $\$ 31$ & $\$ 38$ & $\$ 35$ & $\$ 33$ & $\$ 31$ & $\$ 193$ \\
\hline (7) & so & so & $\$ 0$ & so & so & $\$ 0$ & so & $\infty$ \\
\hline (8) & $\$ 0$ & $\$ 2$ & $\$ 2$ & $\$ 2$ & $\$ 2$ & $\$ 2$ & $\$ 2$ & $\$ 12$ \\
\hline (9) & so & $\$ 2$ & $\$ 2$ & $\$ 2$ & $\$ 2$ & $\$ 2$ & $\$ 2$ & $\$ 12$ \\
\hline (10) & $\$ 3$ & $\$ 14$ & $\$ 14$ & $\$ 14$ & $\$ 14$ & $\$ 14$ & $\$ 14$ & 307 \\
\hline (11) & $\$ 3$ & $\$ 15$ & $\$ 15$ & $\$ 15$ & $\$ 15$ & $\$ 16$ & $\$ 15$ & 393 \\
\hline Total & s & 367 & $\$ 04$ & $\$ 00$ & $\$ 88$ & $\$ 60$ & $\$ 64$ & $\$ 397$ \\
\hline \multicolumn{9}{|c|}{ Privato Investment (million dollare) } \\
\hline$(6+7)$ & $\$ 0$ & $\$ 1,500$ & $\$ 2,000$ & $\$ 3,000$ & $\$ 4,000$ & $\$ 4,500$ & $\$ 4,500$ & $\$ 19,800$ \\
\hline$(8+9+10+11)$ & $\$ 0$ & $\$ 1,300$ & $\$ 1,700$ & $\$ 1,900$ & $\$ 2,300$ & $\$ 2,200$ & $\$ 2,300$ & $\$ 11,700$ \\
\hline Total & $\$$ & $\$ 2,800$ & $\$ 3,700$ & $\$ 4,000$ & $\$ 0,300$ & $\$ 6,700$ & $\$ 0,800$ & $\$ 31,200$ \\
\hline \multicolumn{9}{|c|}{ Annual Groonhouse Oas (OHO) Reduction and Energy Savings } \\
\hline $\begin{array}{l}\text { GHG Reduction } \\
\text { (MMTco) }\end{array}$ & $\mathrm{n} / \mathrm{a}$ & 0.6 & 1.6 & 3.5 & 7.5 & 12.1 & 16.3 & 41.6 \\
\hline $\begin{array}{l}\text { Energy Savings } \\
\text { (quadrillion Btu) }\end{array}$ & $n / a$ & 0.0 & 0.1 & 0.2 & 0.4 & 0.6 & 0.8 & 2.0 \\
\hline
\end{tabular}

Notes: Totals may not equal sum of components due to independent rounding. The budget authority numbers shown in this table reflect the requests made by the various agencies for project funding at the time the Plan was announced; they do not necessarily indicate the actual appropriation of funds.

Analysis Description: The energy savings from The Motor Challenge were based on the assumption that high-efficiency motor systems could potentially reduce industrial electricity consumption used for motor drives by 20 percent in 2010 . Of that 20-percent reduction, one-quarter (25 percent) was assumed to be obtainable by 2000 . The reduction in industrial motor electricity consumption in 2000 was attributed to three sources: (1) standards; (2) research and development; and (3) the Motor Challenge. Only the Motor Challenge savings were counted as part of the Plan, because the others were already included in the Administration Baseline.

Input Assumptions: Industrial electricity consumption in 2010 was based on the 1991 National Energy Strategy (NES) Current Policy Base Case (NES Technical Annex 2, Table B-8). The NES projected that 1,606 billion $\mathrm{kWh}$ would be used by industry in 2010. In addition, another 200 billion $\mathrm{kWh}$ were assumed to be self-generated, bringing total consumption in 2010 to 1,806 billion $\mathrm{kWh}$.

The NES forecast of industrial electricity growth is greater than the Administration Baseline, in part because the latter includes the impacts of EPACT motor standards and research and development. For example, the NES forecasts 1,239 billion $\mathrm{kWh}$ of industrial electricity consumption in 2000 , whereas the Administration Baseline forecast for 2000 is 1,090 billion $\mathbf{k W h}$. Because the percentage savings were computed from the NES forecast, greater energy savings were attributed to the Motor Challenge. However, had the savings been computed from the Administration Baseline, it might have been necessary 
to recompute the percentage savings asoumptions. The net efiect of owitching from the NES forecant to the Administration Baseline forecast would likely be amall.

BPRI report TR-100428, Electric Motors: Markets, Trends and Applications, was used to infor the electric motor arotem share of total indurtrial electricity consumption. According to that report, 66.1 percent of induntrial electricity consumption was attributed to motors (asoumed constant to the year 2010). Thus, the ascumed yoar 2010 electric motor systom onercy consumption is estimated at 1,194 billion $\mathrm{kWh}$.

It was asoumed that about 20 percent of this baseline eners, or 240 billion $\mathrm{kWh}$, could potentially be saved in 2010. The potential savinge are attributable to the following four "efileiency opportunities": motor efileiency improvement-48 billion $\mathrm{kWh}$ per year; electrical dintribution correction - 18 billion $\mathrm{kWh}$ per year; better motor/mechanical aystem matching with motor apeed control (ASDa) and motor downdiaing -99 billion $\mathrm{kWh}$ per year; and process optimization to include the implementation of eficicient motor-driven mechanical equipment (0.8., pumps, fans, and compreseors)-80 billion $\mathrm{kWh}$ par year. A ceries of judgments regarding costs and technologies in each of the four opportunity areas was used to compute the potential 240 billion $\mathrm{kWh}$ savings in 2010 . These are potential savings because the actual saving realized are a product of the estimated average technical potential efiliciency gains and eatimated market penetration rates for different sub-opportunitios under each of the four main "efinciency opportunitios" (Table 25).

Table 28. Assumptions Used to Model the Motor Challenge, Year 2000

\begin{tabular}{|c|c|c|}
\hline Component & $\begin{array}{l}\text { Market Perotration } \\
\text { (Poreent) }\end{array}$ & $\begin{array}{l}\text { Encroy savinges } \\
\text { (Pereent) }\end{array}$ \\
\hline Motor cfficlency improvemem & 4.6 & 10.1 \\
\hline Elentrical distribution correction & 3.0 & 12.5 \\
\hline Better motor/mechanical systeme matching & 15.0 & 13.8 \\
\hline Process optimization & 13.4 & 12.5 \\
\hline
\end{tabular}

For modeling this action, the actual savings in 2000 from motor efficiency improvements were assumed to equal 25 percent of the year 2010 potential savings. Thus, 60 billion $\mathrm{kWh}$ were assumed to be saved in 2000 , but not all of these savings are attributable to the Motor Challenge.

The actual savings from motor efficiency improvements in 2000 (60 billion $\mathrm{kWh}$ ) were attributod to three sources: (1) energy standards -4 billion $\mathrm{kWh}$; (2) impact of research and development-21 billion $\mathrm{kWh}$; and (3) the Motor Challenge-35 billion kWh. The 35 billion $\mathrm{kWh}$ from the Motor Challenge was used for calculating the effects of this action on energy consumption in 2000 . Savings resulting from the Motor Challenge program were decomposed into four categories: (1) motor efficiency improvement, (2) electrical distribution correction, (3) better motor/mechanical systems matching, and (4) process optimization.

\section{(13) Establlsh Industrial Golden Carrot Program for Industrial Alr Compressors, Pumps, Fans, and Drives}

Action Description: DOE will work with businesses to create industrial Golden Carrot programs for air compressors, fans, pumps, and drives. Golden Carrot programs pool utility rebates or the purchasing power of a group of organizations to promote the commercialization of advanced efficiency measures. DOE will work with the consortium for energy efficiency to identify potential efficiency gains from advanced equipment and, in conjunction with utilities, industrial firms, energy users, and nonprofit organizations, will establish uniform specifications and financial incentives for its use. Utilities will also develop contests similar to the Super Efficient Refrigerator contest to commercialize advanced technologies. The 
Government will also coordinate private-eector pooled purchases to enable industrial energy users to make large purchases of high-effeciency equipment at a lower price than individual purchases.

Analyois Description: First, ranges of technical potentials for fans, pumps, compressors, and drives wore evaluated, and point estimates for potential enercy savings were determined. Then, market penetrations were analyzed, based on current natural turnover rates and succeseful Golden Carrot programs already underway. Market penetrations wore multiplied by the technical energy saving potentials to determine percentage energy savings for (1) fans, pumps, and compressors and (2) drives. Fans, pumpa, and compressore were considered in one group, because the available enercy consumption data for the industrial cector did not disaggregate the enersy use for each technology. Finally, percentage energy savings for each of the two groups wore multiplied by total energy use for each group to calculate total enorey savings.

Input Aesumptions: Technical potential energy savings (percentage energy savings relative to baseline technologies) were estimated as follows: fans-2 to 10 percent; pumps -2 to 10 percent; compressors-2 to 10 percent; and drives-1 to 5 percent. The "best guess" point estimate of improvement is 3 percent for drives and 4 percent for all other improvements. Additional market penetration in 2000 resulting from the program was astimated at 5 percent for fans, pumps, compressors, and drives.

\section{(14) Accelerate the Adoption of Energy-Efficlent Process Technologles, Including the Creation of "One-Stop Shops"}

Aotion Deacription: DOE and EPA will work together to remove barriers to the adoption of enercyefficient industrial process tochnologies. "One-stop shops" will disseminate information on clean tochnologies through Stato-based centers. This action will first target energy-intensive process industries such as petroleum refining, chemicals, pulp and paper, and food processing.

Analyois Desoription: The enery savings from this option were determined by combining information on technical and market potential. The technical potential of new processes was based on DOE and BPA judgment and experience from existing programs. Factors considered when estimating market potential included: how much of industrial base of the United States could make use of this program (number of States involved in this program); the percent of businesses in each State that would use this program; and an implementation factor (i.e., of the recommended changes, how much would be implemented by industry).

Input Asoumptions: Induatry could reduce 30 percent of industrial energy consumption by using available technology; the available funding could be used to target 10 States; funding in 10 States could affect 30 percent of industrial energy usage in the United States; 20 percent of the businesses in those States would make use of the one-stop shops; and 20 percent of the possible energy efficiency improvements would be implemented.

In order to incorporate the effects of this action in the IDEAS model, industrial machine drive and electrolytic energy consumption was reduced by 3.3 billion $\mathrm{kWh}$ per year in 2000 , and steam/process heat consumption was reduced by 0.09 quadrillion Btu per year in 2000 . The electricity savings were estimated on the basis of non-motor electric applications, to avoid double counting of the motor system efficiency improvements achieved through the Motor Challenge. The 0.09 quadrillion Btu was computed by applying the percentage improvements cited above to 24 quadrillion Btu of delivered nonelectric energy to the industrial sector $(24 \times 0.3 \times 0.3 \times 0.2 \times 0.2=0.09)$.

\section{(15) Expand and Enhance Energy Analysls and Diagnostic Centers}

Action Description: New and enhanced DOE Energy Analysis and Diagnostic Centers (EADCs), providing no-cost industrial energy audits to small and medium-sized manufacturers, will be established on the basis of industrial demographics and in States that have large value-added industries. Under this agsreacive expansion, the number of audits conducted annually by university engineering faculty and 


\section{The Climate Change Action Plan: Technical Supplement}

students will increase from just over 700 to almost 1,500 per year by 2000 , with a total of 55 EADCs in operation by 2000 . In addition, enhancements will be undertaken to provide a range of implementation support services that are not currently included in the EADC program, including: (a) establishing links with utility industrial DSM programs and State energy conservation programs; (b) expanding the existing EADC collection and reporting system to include marketing information, information on available financing, and life-cycle analysis to encourage plants to consider conservation opportunities beyond the typical 2-year payback cutoff; (c) establishing a best-practice program component providing best-practice profiles and offering annual recognition and awards to model industries; and (d) collaboration with outside process consultants to support consideration of frontier technologies within the EADC process. The expansion and enhancement of the EADC program will create a cadre of qualified professionals trained in energy management, which in turn will create the potential for additional energy savings in enterprises not directly touched by the program.

Analysis Description: A spreadsheet model was used to estimate the combined effect of a number of key variables on energy consumption and carbon emissions. The variables in the model included the following: the number of EAD Centers in operation each year; the number of audits per center per year; the plant implementation rate for EADC-recommended onergy efficiency opportunities; the amount of energy consumed by each plant; and the fuel mix of the average EADC plant.

Input Assumptions: Only small and medium-sized plants are currently permitted to participate in the EADC program. The Administration Baseline assumes $28 \mathrm{EADCs}$ and 780 audits per year constant from 1994 to 2000, and an audit recommendation implementation rate of 40 percent.

The average potential annual energy savings per plant are roughly 4 billion Btu. The annual workload is 30 audits per school, but during the first year of operation EADC schools are assigned 15 audits, or one-half of the annual work load. The number of audits increases by 90 to 150 each year; reaching an annual rate of almost 1,500 audits per year by $55 \mathrm{EADCs}$ in 2000. Plant energy savings implementation rates are expected to improve with the provision of additional information on potential non-DOE funding sources. All initial decisions to implement an energy conservation opportunity are followed up and are implemented completely within 1 year, and all companies audited remain in business. No implemented energy conservation opportunities are withdrawn from operation or dropped after the initial installation.

The fuel mix of small and medium-sized plants subject to reduced use remains constant. The assumed energy savings in Btu are roughly proportional to the fuel mix of EADC clients, i.e., 36 percent electricity, 61 percent natural gas, and 3 percent other fuels. A typical initial private cost of $\$ 8$ per million Btu is assumed, corresponding to a 2- to 3-year payback typical of current EADC audit recommendations. Program costs are approximately $\$ 6,000$ per audit in 1994 , increasing to $\$ 10,000$ per audit per year in 2010.

In order to incorporate the effects of this action in IDEAS, machine drive electrolytic consumption was reduced by 0.8 billion $\mathrm{kWh}$ per year in 2000 , and steam/process heat was reduced by 0.02 quadrillion Btu per year in 2000.

\section{(16) Accelerate Source Reduction, Pollution Prevention, and Recycling}

Action Description: EPA, DOE, and the U.S. Department of Agriculture (USDA) together will promote source reduction, pollution prevention, and recycling of paper and other municipal solid waste (MSW) to reduce greenhouse gas emissions. Source reduction and recycling lead to increased carbon sequestration in forests and reduced energy use in the extraction and processing of virgin materials.

Source reduction efforts will encourage the adoption of unit pricing (charging homeowners by the amount of garbage they throw away), provide incentives and education to practice source reduction, and promote the design of longer life, reparable goods. Recycling efforts will foster "buy recycled" programs, expand access to information clearinghouses, increase the use of government loan guarantees for recycling manufacture investment, and provide technical assistance to State and local governments to improve the quality of recycled materials. The National Industrial Competitiveness through Efficiency, Energy, 
Environment, and Economics (NICE ${ }^{3}$ ) program is a joint DOE/EPA effort that provides grants to diffuse existing technologies, prevent pollution, and improve energy efficiency. This action targets the addition of new processes and/or equipment. This will reduce high-volume wastes in industry, conserve energy and energy-intensive feedstocks, and improve industrial cost-competitiveness. Priorities for the Expanded Paper Recycling Technology Research (USDA Forest Service) include research on recycling solid wood and composites and on recycling paper and paperboard to increase the number of times products can be recycled.

Analysis Description: The analyses of "Expanded Federal Partnerships Programs" and "Expanded Paper Recycling Technology Research" actions were conducted using the same analytic framework. A baseline scenario of waste generation was developed using published projections of materials generation, disposal, and recycling rates for the year $2000 .^{12}$ Materials-specific energy levels for primary and recycled products and industry-specific fuel mixes were used to calculate total energy use and carbon emissions in the baseline scenario. The trends and effects of the existing NICE ${ }^{3}$ program were used as the basis for estimating the effects of an expanded program.

Energy use estimates for the paper, aluminum, plastics, steel, and glass industries were derived from Tellus Institute ${ }^{13}$ and analyses conducted for DOE. ${ }^{14}$ Carbon coefficients for each material were calculated using industry-level fuel mix figures from the Energy Information Administration. ${ }^{15}$ Projected paper recycling rates were input into the Forest Service TAMM/ATLAS model to assess changes in the forest sink through 2000. Timber growing stock inventories from TAMM/ATLAS were converted into their carbon equivalents using the FORCARB model developed by Birdsey. ${ }^{16}$

Input Assumptions: Expanding Federal Partnership programs were estimated to reduce waste generation by 5 percent and increase recycling by 5 percent over what would otherwise occur in 2000 . Expanding paper technology research was assumed to increase levels of paper recycling by an additional 5 percent. For NICEs, one-third of the technologies supported were estimated to result in successful commercial applications. For the successful applications, market penetration of a technology was based on industry estimates for 2010 Penetration was assumed to be linear, starting 1 year after funding. The benefits for future projects funded were assumed to have the same mix as for existing projects.

To incorporate the effects of this action into the IDEAS model, the following year 2000 parameter adjustments were made: machine drive/electrolytics energy consumption was reduced by 11.4 billion $\mathrm{kWh}$; and steam/process heat energy consumption was reduced by 0.15 quadrillion Btu (of that amount, 0.12 quadrillion Btu was assumed to be fossil-based energy).

\section{(17) Improve Efficlency of Fertilizer Nitrogen Use}

Action Description: Improving the efficiency of fertilizer use will result in lower emissions of nitrous oxide $\left(\mathrm{N}_{2} \mathrm{O}\right)$ from reduced microbial activity in the soil and lower carbon dioxide $\left(\mathrm{CO}_{2}\right)$ emissions from electricity and natural gas consumption during the manufacture of fertilizer. The program will expand activity to develop models that focus on trace gas exchange related to the bacterial nitrification and

12. U.S. Environmental Protection Agency, Characterization of Municipal Solid Waste in the United States: 1992 Update, EPA530-R-92-019 (Washington, DC, July 1992).

13. Tellus Institute, Energy Implication of Integrated Solid Waste Management Systems (New York State Energy Research and Devolopment Authority, 1992).

14. Energetics, U.S. Steel Industry: An Energy Perspective, prepared for the U.S. Department of Energy (1988); U.S. Aluminum Industry: An Energy Perspective, prepared for the U.S. Department of Energy (1990); U.S. Pulp and Paper Industry: An Energy Perspective, prepared for the U.S. Department of Energy (1990).

15. Energy Information Administration, Manufacturing Energy Consumption Survey: Consumption of Energy 1988, DOE/DIA-0512(88) (Washington, DC, Nov. 1991).

16. Richard Birdsey, Carbon Storage and Accumulation in United States Forest Ecosystems, USDA Forest Service General Technical Report WO-59 (Washington, DC, 1992). 
denitrification processes. These models will be used to improve nitrogen use efficiency while maintaining an efficient and productive agricultural system. Demonstration projects and an information campaign will ensure widespread application of improved management practices.

Analyais Description: Studies of emissions of $\mathrm{N}_{2} \mathrm{O}$ from "presumably similar" agricultural systems show highly variable results in both time and space. Thus, reliable prediction of the fate of a unit of nitrogen applied or deposited on a specific agricultural field is not yet possible. Recent literature reviews provide ranges of values and even specific percent losses for $\mathrm{N}_{2} \mathrm{O}-\mathrm{N}$ or other fertilizer materials. Selecting a single value to use is difficult and becomes a matter of consensus or judgment, rather than a readily measurable quantity. Once a "reasonable" range or value is chosen to represent losses from U.S. agricultural land, then the percent fertilizer nitrogen lost to the atmosphere must be converted to millions of metric tons of $\mathrm{CO}_{2}-\mathrm{C}$ equivalents (MMTce) per year for comparability. Recognizing the difficulties of using a single value, USDA experts recommend that a value of 23 MMTce per year is reasonable to use for the $\mathrm{N}_{2} \mathrm{O}$ contribution of fertilizer nitrogen applied to agricultural land. Although somewhat higher than some reports of direct emission measurements, a value of 23 should help account for some of the primary and secondary flows of nitrogen through the environment ${ }^{18}$ that are not accounted for by site-specific measurements alone.

The analyais also assumed that this action would reduce phosphate fertilizer use. Although this will not have any direct greenhouse gas reduction as is the case with nitrogen-based fertilizer, it will save enersy used in the manufacture of the fertilizer.

Input Aroumptions: Reductions in nitrogen fertilizer use resulting from this program are expected to be within the 10- to 30-percent reduction proposed in S. 1114 (reauthorization of the Clean Water Act). A point estimate of approximately an 18-percent reduction in 2000 was used for modeling purposes. Phosphate-based fertilizer use was assumed to be reduced by approximately 25 percent in 2000 .

Decreased use of fertilizers also will reduce energy consumption. The energy impacts of this action were modeled in IDEAS by reducing electricity consumption in 2000 for machine drives and electrolytic processes by 3.1 billion $k W h$. Additionally, steam/process heat energy consumption in 2000 was reduced by 0.08 quadrillion Btu.

\section{(18) Reduce Pesticide Use}

Action Description: As in the case of nitrogen fertilizer, the Plan will support technical services for chemicals applied to the land. Reduction in global gas emissions from more efficient pesticide use result from energy savings as less pesticide is manufactured.

Analyais Description: The percentage reduction in pesticide use from existing Integrated Pest Management programs was reviewed. Based on these existing programs and the programs being supported under this action, a percentage reduction in U.S. pesticide use was projected. This percentage reduction was then translated into energy savings in the industrial sector for the manufacture of pesticides.

17. Couneil for Agricultural Science and Technology, Preparing U.S. Agriculture for Global Climate Change, Task Force Ropart No. 119 (Ames, IA, 1992). J.M. Duxbury and A.R. Mosior, "Status and Inoues Concorning Agricultural Bmisaicns of Greenhouse Gases," in Agricultural Dimensions of Global Climate Change (Dolray Boach, FL: St. Lucio Preas, 1998). A.R. Monier and A.F. Bouwman, "Nitrous Oxide Bmicxions from Africultural Soils," Working Group Roport, in Methane and Nitrous Oxides Methods in National Inventories and Options for Control Proceedings (Bilthoven, The Netherlands: RIVM, 1998), pp. 363-346. Organization for Bconomic Cooporation and Devolopment, Batimases of Greenhouse Gas Emiceions and Sinke, Final Report from the OSCD Bxperts Meeting, 18-21 Fobruary 1991, propared for the Intorgovornmental Pand on Climate Change (Paris, France, Aug. 1991).

18. J.M. Durbury and A.R. Mocior, "Status and Inxues Concerning Agricultural Bmievions of Greonhouse Gaves," in Arricultural Dimencions of Global Climate Change (Dolray Beach, FL: St. Lucie Pross, 1898 ). 
Input Acoumptiona: In 2000, U.S. pesticide use was assumed by EPA to be reduced by 32 percent as a result of this prozram. This resulted in the following energy savings in 2000: machine drive and electrolytic processes electricity consumption is reduced by 1.1 billion $\mathrm{kWh}$; and steam/process heat eners consumption is reduced by 0.03 quadrillion Btu.

\section{Industrlal Actions Summary}

Between 1994 and 2000, industrial energy efficiency actions in the Plan will reduce greenhouse gas emiscions by almost 59 MMTce and save 2.8 quadrillion Btu of enerzy (Table 26). This will require almost $\$ 250$ million in Federal outlays and about $\$ 4.85$ billion in private investment.

Table 26. Industrlal Energy Efficlency Actions

\begin{tabular}{|c|c|c|c|c|c|c|c|c|}
\hline Action & FY 1094 & FY 1905 & FY 1 ces & FY 1007 & FY 1000 & FY 1000 & FY 2000 & $\begin{array}{c}\text { FY } 1904-2000 \\
\text { Tetal }\end{array}$ \\
\hline \multicolumn{9}{|c|}{ Foderal Outlays (mullion dollars) } \\
\hline (12) & $\$ 0$ & $\$ 5$ & $\$ 5$ & $\$ 5$ & $\$ 5$ & $\$ 5$ & $\$ 5$ & $\$ 20$ \\
\hline (13) & $\$ 2$ & $\$ 2$ & $\$ 2$ & $\$ 2$ & $\$ 2$ & $\$ 2$ & $\$ 2$ & $\$ 14$ \\
\hline (14) & $\$ 1$ & $\$ 10$ & $\$ 10$ & $\$ 12$ & $\$ 12$ & $\$ 13$ & $\$ 13$ & $\$ 71$ \\
\hline (15) & $\$ 0$ & $\$ 3$ & $\$ 4$ & $\$ 4$ & $\$ 5$ & $\$ 5$ & $\$ 6$ & 927 \\
\hline (16) & $\$ 3$ & $\$ 11$ & $\$ 14$ & $\$ 14$ & $\$ 14$ & $\$ 14$ & $\$ 14$ & $\$ 86$ \\
\hline (17) & so & $\$ 3$ & $\$ 3$ & $\$ 3$ & $\$ 3$ & $\$ 3$ & $\$ 3$ & $\$ 10$ \\
\hline (18) & \$o & $\$ 0$ & $\$ 0$ & $\$ 0$ & $\$ 0$ & $\$ 0$ & 50 & $\infty$ \\
\hline Total & $\$$ & 283 & $\$ 30$ & $\$ 41$ & $\$ 12$ & $\$ 13$ & $\sin$ & 9247 \\
\hline \multicolumn{9}{|c|}{ Private Investment (mullion dollare) } \\
\hline (12) & $\$ 180$ & $\$ 280$ & $\$ 410$ & $\$ 600$ & $\$ 760$ & $\$ 850$ & $\$ 980$ & $\$ 4,000$ \\
\hline$(13+14)$ & $\$ 16$ & $\$ 24$ & $\$ 34$ & $\$ 36$ & $\$ 37$ & $\$ 140$ & $\$ 310$ & $\$ 800$ \\
\hline (15) & $\$ 15$ & $\$ 18$ & $\$ 20$ & $\$ 23$ & $\$ 26$ & $\$ 28$ & $\$ 30$ & $\$ 160$ \\
\hline (16) & $\$ 2$ & $\$ 3$ & $\$ 5$ & $\$ 7$ & $\$ 10$ & $\$ 28$ & $\$ 35$ & $\infty$ \\
\hline Total & $\$ 210$ & $\$ 500$ & $\$ 470$ & $\$ 000$ & $\mathbf{s e n}$ & $\$ 1,000$ & $\$ 1,300$ & $\$ 4,850$ \\
\hline \multicolumn{9}{|c|}{ Annual Crconhouse Cas (GHO) Reduction and Enorgy Savings } \\
\hline $\begin{array}{l}\text { GHG Reduction } \\
\text { (MMTco) }\end{array}$ & $\mathbf{n} / \mathbf{a}$ & 2.4 & 4.8 & 7.6 & 10.4 & 14.6 & 19.0 & 58.7 \\
\hline $\begin{array}{l}\text { Energy Savings } \\
\text { (quadrillion Btu) }\end{array}$ & n/a & 0.1 & 0.2 & 0.4 & 0.5 & 0.7 & 0.9 & 2.8 \\
\hline
\end{tabular}

Notes: Totals may not equal sum of components due to independent rounding. The budget authority numbers shown in this table reflect the requests made by the various agencies for project funding at the time the Plan was announced; they do not necessarity indicate the actual appropriation of funds. 


\section{Transportation Actions}

\section{(19) Reform Federal Tax Subsidy for Employer-Provided Parking}

Action Description: This action is a change in the Internal Revenue Code section relating to the taxation as income of employer-provided parking. The action will reduce vehicle travel and traffic congestion by providing employees a powerful new incentive to carpool, take transit, or find other ways to get to work. The change requires some employers to offer a cash allowance as an option to tax-exempt parking subsidies as a condition of the tax exemption.

Analysis Description: Offline analysis was used to calculate the impacts of "cashing out" parking on vehicle miles traveled (VMT) by light-duty vehicles on an annual basis. The total amount of parking affected by the program was estimated by a combination of labor force projections, commuting trends, and parking market data. Adjustments were made to account for likely exemptions to the cash-out requirement. Program impact (the percentage of employees offered cash-out who take it) was estimated on the basis of observed employee reaction to similar changes in driving costs. The after-tax value of the cash-out incentive was used to model the change in employee driving costs. During the 1994-2000 period, the analysis assumed that the short-term supply of parking spaces was relatively inelastic. As a result, drivers not taking the cash-out would occupy some of the vacated parking. The impacts of EPACT provisions relating to the tax treatment of parking and transit were also considered.

Input Assumptions: Key assumptions are detailed in Table 27. As a result of the cash-out program, VMT declines by approximately 25 billion (1.1 percent) in 2000 (bottom row, Table 27). The impact of this program on traffic congestion and, therefore, fuel economy was not considered. Separate analyses were conducted for impacts in large urban areas (over 1 million population) and small urban areas (1 million or smaller population). Sources for the key input assumptions are detailed below.

- Labor Force: Separate analyses were conducted for impacts in large and small urban areas, defined by metropolitan statistical areas (MSAs). Data on the percentage of the labor force employed in large and small metropolitan areas were provided by the Bureau of Labor Statistics and the Office of Management and Budget.

- Employer Size: Small employers (with 25 or fewer employees) were assumed to be exempt from any cash-out program. Data on the percentage of the labor force employed in firms of fewer than 25 employees were provided by the Office of Management and Budget.

- Drive-alone Rate: A parking cash-out program is assumed to have a direct impact only on persons currently driving to work solo-so-called "single occupant vehicle" (SOV) drivers. Data on drive-alone rates were obtained from the U.S. Department of Transportation's 1990 Nationwide Personal Transportation Survey (NPTS). Without the cash-out program, drive-alone rates were assumed to remain constant at their 1990 levels over the 1994-2000 period. Recent studies have shown modest increases in drive-alone rates in some areas. ${ }^{19}$

- Drivers Receiving Free Parking: A parking cash-out program is assumed to have a direct impact only on persons currently receiving free parking at their place of work. Data used here are from the NPTS. Other studies have come to similar findings. ${ }^{20}$ Without the cash-out program, the frequency of free parking was assumed to remain constant at its 1990 over the 1994-2000 time period.

- Rented Parking Share: This figure is the percentage of employer provided parking likely to be affected by the cash-out requirement. The specific option identified in the Plan would include only parking

19. State of the Commute (Commuter Transportation Services, 1993).

20. Donald Shoup, Cashing Out Employer-Paid Parking, FTA-CA-11-0035-92-1 (Federal Transit Administration, 1992). 
Table 27. Inputs for the Parking Cash-Out Option Under Action (19)

\begin{tabular}{|c|c|c|c|c|}
\hline \multirow[b]{2}{*}{ Input } & \multicolumn{2}{|c|}{$\begin{array}{l}\text { Large Urban Areas } \\
\text { (>1 Million Population) }\end{array}$} & \multicolumn{2}{|c|}{$\begin{array}{l}\text { Small Urban Arves } \\
\text { (et Million Population) }\end{array}$} \\
\hline & 1994 & 2000 & 1994 & 2000 \\
\hline Non-military Labor (thousands) & 54,499 & 68,850 & 31,590 & 39,150 \\
\hline Firms of 25 or More Employees & $77 \%$ & $77 \%$ & $77 \%$ & $77 \%$ \\
\hline Drive-alone Rate & $69 \%$ & $69 \%$ & $75 \%$ & $75 \%$ \\
\hline Drivers Recoiving Free Parking & $88 \%$ & $88 \%$ & $89 \%$ & $89 \%$ \\
\hline Rented Parking Share & $15 \%$ & $50 \%$ & $15 \%$ & $50 \%$ \\
\hline Drivers Otfered Cash-Out (thousands) & 3,822 & 16,095 & 2,420 & 9,996 \\
\hline Porsonal Marginal Tax Rate & $32 \%$ & $32 \%$ & $32 \%$ & $32 \%$ \\
\hline Vohicle Miles Traveled (VMT) from Home to Work per Year & 5,185 & 5,680 & 5,185 & 5,680 \\
\hline Monthly Driving Cost & $\$ 40.45$ & $\$ 47.00$ & $\$ 40.45$ & $\$ 47.00$ \\
\hline Monthly Value of Parking & $\$ 63.00$ & $\$ 73.20$ & $\$ 32.00$ & $\$ 37.18$ \\
\hline Opt-outs: Cash Share & $80 \%$ & $80 \%$ & $90 \%$ & $90 \%$ \\
\hline After-Tax Consequences & $\$ 42.84$ & $\$ 49.78$ & $\$ 21.76$ & $\$ 25.28$ \\
\hline Change in Driving Cost & $106 \%$ & $106 \%$ & $54 \%$ & $54 \%$ \\
\hline Opt-outs: Transit Share & $20 \%$ & $20 \%$ & $10 \%$ & $10 \%$ \\
\hline After-Tax Consequences & $\$ 62.56$ & $\$ 72.69$ & $\$ 32.00$ & $\$ 37.18$ \\
\hline Change in Driving Cost & $155 \%$ & $155 \%$ & $79 \%$ & $79 \%$ \\
\hline Average Change in Driving Cost & $116 \%$ & $116 \%$ & $56 \%$ & $56 \%$ \\
\hline Elasticity of Home to Work VMT with Respect to Cost & 0.15 & 0.2 & 0.1 & 0.125 \\
\hline Cash-Out Acceptance Rate" & $17.35 \%$ & $23.13 \%$ & $5.63 \%$ & $7.04 \%$ \\
\hline Number of Persons Opting Out (thousands)" & 663 & 3,723 & 136 & 704 \\
\hline Dollar Amount Cashod Out (millions)" & 401 & 2,620 & 47.1 & 283 \\
\hline Number of Transit Passes (thousands)* & 133 & 745 & 14 & 70 \\
\hline Change in Miles Traveled (millions)" & $-3,440$ & $-21,100$ & -707 & $-4,000$ \\
\hline
\end{tabular}

"Calculation based on primany inputs.

spaces leased by employers from a third party for which the lease allows a reduction in the number of parking spaces without penalty, and all urban parking subject to new lease agreements made after January 1, 1994. Data on the percentage of employer-provided parking that is owned or leased, type of lease arrangement, and typical lease duration were gathered from a number of sources, including studies conducted by the Federal Transit Administration and Commuter Transportation Services. Since no single comprehensive data source exists, point estimates relied heavily on the expert judgement of staff and outside experts.

- Commuter VMT per Year: Figures for the typical mileage of home-to-work trips (workday commutes from home to work and back) were taken from the NPTS for 1990. To project baseline VMT growth during the 1994-2000 period, commuter VMT were increased at the per-capita VMT growth rate used in the IDEAS model for that period. According to NPTS, commuter VMT are only about 25 to 35 
percent of total VMT. The analysis did not consider impacts on other VMT, including work-related VMT (lunchtime trips, linked trips, etc).

- Nonparking Driving Cost per Mile: These figures were based on a marginal driving cost of 9.4 cents per mile provided by the American Automobile Association (AAA), multiplied by monthly driving rates from the NPTS.

- Opt-outs: Transit Share: These are the percentages of those who take the cash-out who choose transit and other ways of getting to work (e.g., carpool, walk, bicycle, telecommute). Although few data exist on this point, anecdotal evidence suggests that most people would choose carpooling. The percentage who choose mass transit would obviously be higher in large urban areas.

- Elasticity of VMT with respect to cost of travel: To determine consumer response to an offer of cash for parking, that cash was converted to a per-mile cost based on typical commuting distances. An assumption was made concerning consumer reaction in terms of driving with respect to the cost per mile of driving. This analysis relied for that assumption on the consensus of studies of short-term elasticity of VMT with respect to gasoline cost." Elasticities were then discounted by 25 percent in order to ensure that impacts were not overestimated. In the IDEAS model, this option was modeled as reducing light-duty vehicle VMT by 27 billion miles in 2000.

\section{(20) Adopt a Transportation System Efficlency Strategy}

Action Description: This action is an effort to promote public and private sector policies and activities that reduce growth in vehicle travel. This initiative uses tangible policy levers-Clean Air Act credits, a strong Transportation Conformity rule, and Intermodal Surface Transportation Efficiency Act funding-to lead State and local governments toward measures that dampen growth in vehicle travel. Outreach efforts will encourage the States to take advantage of Federal incentives. To better inform State and local decisionmakers and to put demand management and capacity expansion on equal footing, EPA and DOT will work together with State and local officials to sharpen the tools used to analyze transportation infrastructure and policy.

Analysis Description: Offline analysis was used to calculate impacts on light-duty VMT. Analysis of individual measures promoted in this action were conducted. Second, an estimate was made of the VMT reductions likely to be needed over the 1994-2000 period to meet Clean Air Act Transportation Conformity requirements. The two factors were used together to develop a national VMT reduction estimate.

Input Assumptions: Several measures were analyzed for this action, inciuding a pay-as-you-drive insurance payment system, cash for clunkers, and increased road pricing. Ten percent of the light-duty vehicles on the road were assumed to be covered by policies having the same effect as a 25-cent-per-gallon increase in gasoline prices by 2000 . This, together with other measures, was assumed to reduce VMT growth by 0.2 percent per year from 1994 to 2000 relative to its baseline levels. However, this impact was discounted by one-half to account for overlap with parking cash-out and other Plan initiatives. For modeling purposes, year 2000 VMT in IDEAS was reduced by 0.7 percent relative to baseline levels.

\section{(21) Promote Greater Use of Telecommuting}

Action Description: Telecommuting has the potential to substitute work at home or "satellite" locations for work at a central office, thereby reducing the number and length of daily work trips. In this action item, DOT and EPA will promote telecommuting through a series of initiatives intended to increase employer and employee awareness and understanding of the benefits of telecommuting, remove barriers to telecommuting, and encourage States to promote telecommuting as a travel demand reduction strategy. Specific elements of the strategy include:

21. C. Dahl and T. Sterner, "Analyzing Gasoline Domand Elanticities: A Survey," Energy Economice (July 1891). 
- BPA, in consultation with DOT, will issue guidance for States to take measures to promote telecommuting.

- DOT will encourage States to use Intermodal Surface Transportation Efficiency Act (ISTEA) funds to initiate or expand telecommuting programs.

- DOT will implement a Federal telecommuting pilot project with the goal of getting 1 to 2 percent of Feideral employees to work at home at least one day a week.

- DOT, in conjunction with other agencies, will develop a national "work-at-home" campaign.

Analysis Description: DOT, in its recent study of telecommuting, ${ }^{22}$ developed lower- and upper-bound estimates of telecommuting levels and impacts on travel, energy use, and emissions through the year 2002. Recent trends suggest that telecommuting could even exceed DOTs upper-bound estimates. The elements of this action item, taken together, are assumed to increase the levels of telecommuting by a relatively modest amount within this range. Specifically, this action item is assumed to increase telecommuting by an amount equal to approximately 30 percent of the difference between the lower- and upper-bound estimates for 2000.

Input Assumptions and Results: Estimates for the year 2000 from the DOT study and for this action item are shown in Table 28. DOT estimates an upper-bound reduction in fuel consumption due to telecommuting in 2000 of about 1.2 billion gallons of motor fuel. Recent trends indicate that this figure could go even higher, up to 1.5 billion gallons in 2000 .

Table 28. Potential Impacts from Telecommuting, Year 2000

\begin{tabular}{||c|c|c|c|}
\hline \multicolumn{1}{|c|}{ Case } & $\begin{array}{c}\text { Tolscommuting Days por Week } \\
\text { (million) }\end{array}$ & $\begin{array}{c}\text { Vohicle Milos Traveled } \\
\text { (billion) }\end{array}$ & $\begin{array}{c}\text { Casolline Saved } \\
\text { (million gallons) }\end{array}$ \\
\hline DOT Lower Bound & 21.2 & 14.5 & 690 \\
\hline DOT Upper Bound & 36.3 & 24.7 & 1,180 \\
\hline Action Plan Effoct & 5.0 & 3.3 & 170 \\
\hline
\end{tabular}

\section{Develop Fuel Economy Labels for Tires}

Action Description: Tires have a significant impact on vehicle fuel economy through their level of "rolling resistance." Efficient tires increase fuel economy by about 4 percent over average replacement tires with comparable performance. In this action, DOT will establish a tire labeling program for the replacement tire market. This program will be mandatory for most light-duty vehicle tires. If possible, a voluntary labeling program will be established for heavy-duty truck tires.

The tire labels will indicate the impact of the tires on fuel economy and may include a rating system (e.g., tire grades A-F), as DOT currently does for other tire attributes (traction and treadwear life). The labels and a DOT-initiated publicity campaign will encourage both consumers and businesses to purchase-and manufacturers to produco-more fuel-efficient tires.

Analysis Description: The analysis of the impacts of the tire labeling program involves estimating the percentage of the replacement tire market that would shift from average rolling resistance (i.e., average fuel efficiency) to low rolling resistance for each future year, starting in 1995. Most of the shift in rolling

22. U.S. Department of Transportation, Transportation Implications of Telecommuting, Report to Congress (Washington, DC, March 1993). 
resistance is expected to come from revised product offerings by manufacturers, rather than consumer shifts in purchase patterns. The analysis depends on the number of replacement light-duty and heavyduty vehicle tires sold each year, the percentage that are low-rolling-resistance (LRR), the number of miles driven on these tires, and the fuel economy impacts of each low-rolling-resistance tire. Average tire life was assumed to be 40,000 miles for light-duty vehicles and 150,000 miles for heavy-duty vehicles.

The Federal costs of this program are minimal, because testing will be done by manufacturers with DOT certification.

Input Assumptions and Results: Table 29 shows the key IDEAS input assumptions used for modeling this program.

Table 29. IDEAS Parameter Inputs for Tire Fuel Economy, Year 2000

\begin{tabular}{|l|c|c|}
\hline \multicolumn{1}{|c|}{ Measure } & Light-Duty Vohicles & Hoavy-Duty Vohicles \\
\hline On-road efticiency improvement (miles per gallon) & 0.9 & 0.5 \\
\hline Market penetration (percent) & 7.5 & 11.0 \\
\hline $\begin{array}{l}\text { Increase in average fleet on-road fuel economy } \\
\text { (miles per gallon) } \\
\text { (percent) }\end{array}$ & 0.068 \\
4.0 & 0.055 \\
\hline
\end{tabular}

\section{Transportation Actions Summary}

Between 1994 and 2000, transportation energy efficiency actions in the Plan will reduce carbon emissions by almost 31 MMT and save 1.6 quadrillion Btu of energy (Table 30). This will require almost $\$ 91$ million in Federal outlays and about $\$ 2.2$ billion in private investment.

\section{Energy Supply Actions}

(23) Increase Natural Gas Share of Energy Use through Federal Regulatory Reform

Action Description: This action supports additional efforts by the Federal Energy Regulatory Commission (FERC) to expand and improve natural gas markets through regulatory reform. These efforts will include: (a) exploration of ways to allow more efficient resale transactions by the primary holders of firm natural gas pipeline capacity; (b) promulgation of a "performance regulation" approach to rulemaking that would result in lower prices for pipeline capacity; anu (c) investigation of current rules that may cause unwarranted delays in the construction of new natural gas pipeline capacity. All these actions would result in more efficient market transactions for natural gas, lower prices for pipeline capacity, and increased demand for natural gas. The lower cost of delivered gas services would displace coal and oil in some instances, thereby resulting in lower net greenhouse gas emissions.

Analysis Description: The effect of regulatory reforms on natural gas use was analyzed offline by Dr. Rodney Lemon of Argonne National Laboratory. He estimated separate impacts from 1994 to 2010 for the residential, commercial, industrial, and electric utility sectors. He calculated these impacts by estimating two changes resulting from Federal regulatory reforms-changes resulting from lowered pipeline charges and changes resulting from increased reliability of natural gas, leading to a shift in the demand curve. Because of concerns regarding the feasibility of implementing all of the modeled reforms on a timely basis, these offline estimates were reduced by about 45 percent before being incorporated into the IDEAS model. 
Table 30. Transportation Energy Efflclency Actions

\begin{tabular}{|c|c|c|c|c|c|c|c|c|}
\hline Aotion & FY 1904 & FY 1898 & FY 1809 & FY 1997 & FY 1998 & FY 1000 & FY 2000 & $\begin{array}{c}\text { Fy 1004-2000 } \\
\text { Total }\end{array}$ \\
\hline \multicolumn{9}{|c|}{ Fodoral Outlays (million dollare) } \\
\hline (19) & \$o & $\$ 0$ & $\$ 0$ & $\$ 0$ & $\$ 0$ & $\$ 0$ & so & $\mathbf{1 0}^{*}$ \\
\hline (20) & $\$ 3$ & $\$ 12$ & $\$ 15$ & $\$ 16$ & $\$ 15$ & $\$ 14$ & $\$ 14$ & 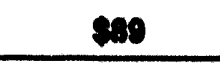 \\
\hline (21) & so & so & $\$ 0$ & so & so & $\$ 0$ & $\$ 0$ & $\infty$ \\
\hline (22) & $\$ 0.3$ & $\$ 0.3$ & $\$ 0.3$ & $\$ 0.3$ & $\$ 0.3$ & $\$ 0.3$ & $\$ 0.3$ & 9 \\
\hline Total & $\$ 3$ & $\$ 12$ & $\$ 15$ & $\$ 16$ & $\$ 16$ & $\$ 15$ & $\$ 15$ & $\$ 01$ \\
\hline \multicolumn{9}{|c|}{ Private Investment (million dollars) } \\
\hline (22) & $\$ 0$ & $\$ 270$ & $\$ 300$ & $\$ 340$ & $\$ 380$ & $\$ 440$ & $\$ 470$ & $\$ 2,200$ \\
\hline \multicolumn{9}{|c|}{ Annual Greenhouse Gas (GHG) Reduction and Energy Savinge } \\
\hline $\begin{array}{l}\text { GHG Reduction } \\
\text { (MMTco) }\end{array}$ & $\mathrm{n} / \mathbf{a}$ & 1.6 & 3.3 & 4.5 & 5.9 & 7.1 & 8.1 & 30.5 \\
\hline $\begin{array}{l}\text { Energy Savings } \\
\text { (quadrillion Btu) }\end{array}$ & n/a & 0.1 & 0.2 & 0.2 & 0.3 & 0.4 & 0.4 & 1.6 \\
\hline
\end{tabular}

"This action will generate $\$ 2.2$ billion in Federal tax revenue in the FY $1994-2000$ period.

Notes: Totals may not equal sum of components due to independent rounding. The budgot authority numbers shown in this table reflect the requests made by the varbus agencies for project funding at the time the Plan was announced; thoy do not necessarily indicate the actual appropriation of funds.

While industries would incur some costs in the rulemaking process, the ultimate result would be lower average costs. Among the industry participants (producers, pipelines, local distribution companies, and consumers), some would gain and some would not; but the net cost to society would be lower. FERC would experience some additional analytic costs in carrying out the rulemaking and implementing it, but there would be no additional long-term costs to FERC once the rules were implemented. Indeed, FERC's long-run economic needs are likely to be reduced.

Input Assumptions: Table 31 shows the year 2000 parameter adjustment used in IDEAS to model the effects of this action.

Table 31. IDEAS Parameter Adjustments for Natural Gas Regulatory Initiatlves, Year 2000

\begin{tabular}{|l|c|}
\hline \multicolumn{1}{|c|}{ Adjustmont Factor } & Adjustmont Compared to Basoline \\
\hline Price Reductions (percont) & 1.0 \\
Residential/Commercial & 4.0 \\
Industrial & \\
\hline Shit in Natural Cas Domand Curvo (quadrillion Btu) & 0.35 \\
Residential & 0.04 \\
Commorcial & 0.03 \\
Industrial & 0.00 \\
Transportation & -0.02 \\
Utility & \\
\hline
\end{tabular}




\section{(24) Promote Seasonal Gas Use for the Control of Nitrogen Oxides $\left(N_{x}\right)$}

Action Description: The Administration will aggressively promote the summer use of natural gas in utility coal and oil plants and in industrial facilities as an innovative, low-cost $\mathrm{NO}_{\mathrm{x}}$ reduction strategy. This action, which will reduce $\mathrm{NO}_{\mathrm{x}}$ emissions that contribute to smog formation during summer months, would also reduce carbon emissions through seasonal substitution toward low-carbon fuel. EPA recently issued a guidance document describing how States may use seasonal gas strategies to meet $\mathrm{NO}_{x}$ reasonably available control technology (RACT) requirements under the Clean Air Act.

Analysis Description: The analysis assumed that a seasonal gas use strategy would be an attractive option in the following nonattainment areas: Northeast Transport Region (i.e., Washington, DC, metro area to Maine), Chicago/Milwaukee, Atlanta, and Houston. A preliminary screening analysis indicated that 20 percent of the electric utility coal-fired capacity in the Northeast Transport Region would be amenable to a seasonal gas use strategy (i.e., uncontrolled coal-fired emissions rates are low enough in 20 percent of the units that, when averaged in with 5 or 6 months of summer gas use at an emissions rate of approximately 0.2 pounds per million Btu, those units would meet the annual emission cap). It was assumed that a similar proportion of coal- and oil-fired plants in the other regions would be amenable to a seasonal gas use strategy. Intrastate and intra-utility system $\mathrm{NO}_{\mathrm{x}}$ reductions trading will allow a seasonal strategy to be more widely adopted.

Input Asoumptions: The analysis assumed that the Federal Government would actively promote the adoption of seasonal gas use for the control of $\mathrm{NO}_{\mathrm{x}}$ and that States would allow the inclusion of such strategies in their State Implementation Plans for Clean Air Act attainment. The high cost of control for volatile organic compound (VOC) emissions and the increased scientific evidence for the importance of $\mathrm{NO}_{\mathrm{x}}$ control in preventing peak smog episodes would also support the adoption of seasonal gas use strategies. It was further assumed that sufficient gas supplies and pipeline capacity would be available and competitively priced in the summer months. Finally, it was assumed that the ability to average emissions limits among units would make a strategy that combined stack scrubbing, seasonal gas use, and other control measures attractive to a large base of coal-fired plants.

This option was modeled in IDEAS under the assumption that 5 percent of coal-fired generation capacity (10 percent of utilities participate with 50 percent of their capacity) would use a seasonal burn strategy (7 months of the year) in 2000.

\section{(25) Commerclalize High-Efficlency Gas Technologles}

Action Description: DOE will provide cost sharing for up to 100 200-kilowatt fuel cells each year during the 1995-1997 period. DOE will provide up to one-third of the rebate funds required to bring fuel cells to market. Anticipated payback of this funding will come from royalties on future sales.

DOE will initiate additional demonstrations of advanced fuel cells, which are expected to cause market entry of the advanced fuel cells. This portion of the initiative will be co-funded with the private sector, with DOE providing approximately one-third of the cost of demonstrations.

Analysis Description: Reductions of carbon emissions were estimated from projected deployment of high-efficiency fuel cells in distributed generation of electricity. Estimates of the market penetration of fuel cells were based on the judgment of analysts familiar with fuel cell technology and potential.

Input Aesumptions: This action was modeled in IDEAS by assuming that 280 megawatts of gas fual cells would come online in 2000 , with a year 2000 capital cost of $\$ 617$ per kilowatt (1991 dollars), a heat rate of 6,450 Btu per $\mathrm{kWh}$, and operating and maintenance (O\&M) costs of 6.9 mills per $\mathrm{kWh}$. 


\section{(26) Form Renewable Energy Market Mobllizatlon Collaborative with Technology Demonotratlons}

Aotion Description: DOE will collaborate with private industry to accelerate market acceptance of renewable enersy technologies and to conduct industry cost-shared demonstrations of these technologies in multiple regions of the United States. DOE will fund utility/independent power industry consortia to pool purchases of nearly commercial renewable systems, resulting in new systems in place by 1996. DOE will also join forces with these consortia and with States in cost-shared demonstrations of larger renewable enersy systems. This action will field validate these technologies within specific utility systems, thereby increasing utility and investor confidence and removing a key market barrier.

Analysil Description: The benefits are estimated to result both from the co-funded projects (direct benefits) and from projects funded completely by the electric industry as a result of the technology field validation (indirect benefits). The direct benefits were estimated by allocating the anticipated Federal funding, together with anticipated cost sharing (based on current experience), into specific projects in the wind, solar, and biomass areas, based on current cost and performance. To be conservative, only the direct benefits of this option were modeled.

Input Assumptions: This action was represented by assuming improvements in the cost and performance of the renewable energy technologies relative to the Administration Baseline (Table 32). While costs would be expected to decrease as a result of this action, increased utility and investor experience and confidence-and not cost savings-would be the principal effect of the action. However, since these factors are not explicitly represented in IDEAS, the action was modeled by modifying the technology cost and performance assumptions to match the benefits estimated independently. When the Combined Policy Case was run, the benefits for this action decreased because of lower projected electricity demand.

Table 32. IDEAS Technology Assumptlons for Actlon (26), Year 2000

\begin{tabular}{|c|c|c|c|c|}
\hline Renowable Technology" & $\begin{array}{l}\text { Capital Cost } \\
\text { (1901 dollars } \\
\text { per kllowatt) }\end{array}$ & $\begin{array}{l}\text { OsM Cost } \\
\text { (milla/kWh) }\end{array}$ & $\begin{array}{c}\text { Capacity Factor } \\
\text { (percont) }\end{array}$ & $\begin{array}{l}\text { Hoat Rate } \\
\text { (Btu/kWh) }\end{array}$ \\
\hline Wind & $\begin{array}{c}660 \\
(-15 \%)\end{array}$ & $\begin{array}{c}8.5 \\
(-15 \%)\end{array}$ & $\begin{array}{c}38 \\
(+27 \%)\end{array}$ & -- \\
\hline Goothermal & 2,169 & 16.4 & $\begin{array}{r}86 \\
(+4 \%) \\
\end{array}$ & -- \\
\hline Biomass & 1,092 & $\begin{array}{c}9.2 \\
(-5 \%)\end{array}$ & 70 & 10,000 \\
\hline Solar Thormal & $\begin{array}{c}1,577 \\
(-10 \%)\end{array}$ & 9.8 & 37 & - \\
\hline Solar Photovoltalc & $\begin{array}{l}2,297 \\
(-10 \%)\end{array}$ & 2.2 & $\begin{array}{l}30 \\
(+7 \%)\end{array}$ & -. \\
\hline
\end{tabular}

"Numbers in parentheses show change relative to the Administration Baseline.

\section{(27) Promote Integrated Resource Planning}

Action Description: Integrated resource planning (IRP) stresses systematic consideration of all relevant options and uncertainties in the development of a utility's resource plan. Such options include both supply and demand resources, such as renewable generating technologies, programs to help customers improve energy efficiency or use alternative fuels, utility investments to improve the efficiency of their generation, transmission, and distribution equipment, purchase of electricity from non-power producers, and electricity imports from Canada. To promote IRP, DOE will provide technical and intervention support in rulemaking processes to: 
- Remove barriers to increased use of natural gas and investments in efficiency measures in generation, tranamisaion, and distribution of power

- Favor regulatory approaches that make utility investments in energy efficiency and conservation as profitable as aupply-side investments

- Support DSM by electric and natural gas utilities

- Promote rate design reform

- Support least-cost Clean Air Act compliance.

The IRP program will provide a supportive regulatory foundation for the adoption of energy-efficient technologies encouraged by other commercial, residential, and industrial demand actions.

Analyois Description: The expected impacts of this option were estimated on the basis of a projected increase in the level of DSM expenditures by electric utilities over the remainder of this decade. The baseline was defined by the DSM expenditures and energy savings projected by major utilities in their responses to a 1991 survey conducted by the Energy Information Administration (EIA). The supply-eide impacts of this action were not considered here, but were incorporated within other supply actions in the Plan.

Input Assumptions: It was assumed that a substantial increase in Federal technical and other support for utility IRP, in conjunction with the implementation of the relevant requirements of EPACT, would cause the percentage of utilities participating in DSM to rise from a baseline value of 12 percent in 2000 to 14.5 percent. This would increase the energy savings from DSM by a proportionate amount.

\section{(28) Rotaln and Improve Hydroelectrlc Generation at Existing Dams}

Action Description: This strategy is a twofold initiative to remove barriers to the use of environmentally sound hydroelectric generation. FERC, in conjunction with other interested agencies, can act to remove regulatory barriers to low-impact, non-Federal hydroelectric development at existing dams. At the same time, the Administration will remove regulatory barriers to private funding of generation improvements at existing Federal water facilities. DOE will review all Federal water facilities to identify opportunities for economically improving hydroelectric generation. The Buroau of Reclamation and the U.S. Army Corps of Engineers will continue to conduct feasibility studies, but instead of asking Congress for appripriations to make generation improvements, they will request private-sector bids for the lease of the development rights.

Analyeis Description: Three gigawatts (GW) of additional hydropower capacity were assumed to be developed by 2000 as a result of this action. Based on the age of existing Corps of Engineers facilities and past experience with upgrading facilities, the Corps estimated that $2 \mathrm{GW}$ of capacity could come from Corps facilities through efficiency improvements to existing generating units. Based on a recent review of a 1988 study, the Corps estimated that $0.3 \mathrm{GW}$ of capacity could come from Corps facilities through other low-impact improvements. A Bureau of Reclamation study in support of its Hydropower 2002 initiative indicates that $0.2 \mathrm{GW}$ of capacity could come from efficiency improvements at existing Bureau generating units. DOE estimates that $0.5 \mathrm{GW}$ would come from low-impact non-Federal development at existing dams licensed by FERC. (This $0.5 \mathrm{GW}$ is a small fraction of the $4.4 \mathrm{GW}$ of potential hydroelectric development at non-Federal existing dams identified by DOE for the NES).

Input Ansumptions: It was assumed that $3.0 \mathrm{GW}$ of additional hydroelectric capacity would be developed, and that the capacity factor for the additional capacity would be 30 percent.

The sale of $2.5 \mathrm{GW}$ in upgrade opportunities would generate $\$ 480$ million for the Treasury. Federal costs are expected to be $\$ 4$ million over a 2-year period to conduct a review of all Federal water facilities to identify the potential for improving hydroelectric generation.

Assuming a 30-percent capacity factor and a market price of $\$ 0.04$ per $\mathrm{kWh}$, the annual revenue stream from sales of electricity from upgrades at Federal facilities would be about $\$ 270$ million. Assuming a rate of return of 12 percent, the present value of a revenue stream of $\$ 270$ million assumed to start 2 years after investment would be about $\$ 1.8$ billion. The capital cost of $2.5 \mathrm{GW}$ is $\$ 1.25$ billion, assuming a cost 
of $\$ 500$ per kilowatt of capacity. Taking into account the capital cost, investors could bid up to $\$ 480$ million for the rights to implement these upgrades.

The private investment for the non-Federal development at existing dams is estimated to be $\$ 1,000$ per kilowatt of capacity, or about $\$ 500$ million for the projected $0.5 \mathrm{GW}$ of capacity.

\section{(29) Accelerate the Development of Efficlency Standards for Electric Transformers}

Action Description: Under Section 124 of EPACT, DOE will accelerate the development of efficiency standards for electric tranaformers and implement the new standards by 1995-96 in order to reach maximum energy savings by 2000. The use of higher efficiency electric transformers will reduce electricity losses in the distribution system and reduce the amount of electricity that utilities must generate.

Analyuis Description: The savings estimate for this option was based on the assumption that standards would be set at a level equivalent to what high-efficiency silicon steel transformers could meet, and that the standards would take effect in 1995.

Input Asoumptions: In the year 2000, these standards-together with Energy Star transformers [8ee action (30)\}-would save 3 billion $\mathbf{k W h}$ of electricity per year.

\section{(30) Launch Energy Star Transformers}

Action Description: EPA will implement a voluntary program to encourage electric utilities to inveat in high-efficiency transformers that reduce transformer losses (approximately 50 billion $\mathrm{kWh}$ are lost per year in transformers). EPA would work with industry to establish minimum efficiency levels, and all qualifying equipment would be designated with the Energy Star logo. Participating utilities would agree to purchase only energy star transformers and to upgrade their systems (early retirement) where economically warranted. EPA would distribute information regarding energy-efficient transformers to utilities and State public utility commissions (PUCs), and help participating utilities to organize group purchases of energy-efficient transformers in order to obtain lower prices.

Analysis Description: The Energy Star program works in conjunction with energy standards to increase the market penetration of high-efficiency transformers.

Input Assumptions: By the year 2000, the annual electricity savings resulting from this program and efficiency standards for transformers [action (29)] will be approximately 3 billion $\mathrm{kWh}$.

\section{(31) Reduce Electric Generation Losses Through Transmission Pricing Reform}

Action Description: FERC regulates the pricing of wholesale electric transmission service. On June 30, 1993, FERC issued a notice of inquiry on transmission pricing issues. The Administration, through DOE, will support transmission pricing reform that reflects the benefits of reverse flows. In 1991, about 211 billion $\mathrm{kWh}$, or 7.4 percent of U.S. electric generation, was lost while being distributed from power plants to end users. Many of the interutility, interregional transmission corridors in the United States are heavily loaded during peak hours. Transactions that go against prevailing power flows reduce total line losses, and hence total fuel consumption, within a region.

Analyois Description: Offline analysis determined that transmission pricing that reflects the benefits of reverse flows is likely to reduce total U.S. losses by approximately 2 percent. Wholesale power markets have become quite competitive; there is now a quasi-market-clearing price for both short-term and longterm wholesale power supplies. The siting of new power plants and spot market transactions will both be sensitive to transmission pricing. This sensitivity will help save energy, because the benefits of reverse flows will be captured in market transactions.

Input Assumptions: As a result of this action, transmission and distribution efficiency were assumed to increase by 0.15 percent in 2000 . In IDEAS, this resulted in a reduction of 0.1 percent in electricity generation, which is equivalent to 3.2 billion $\mathrm{kWh}$ in 2000. 


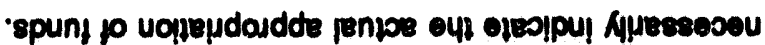

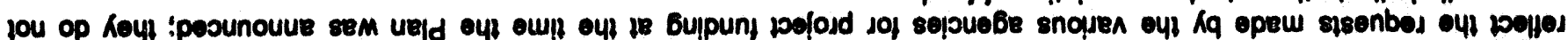

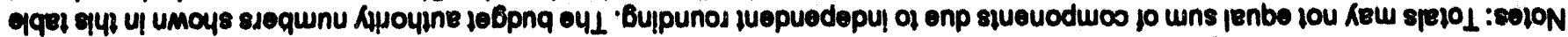

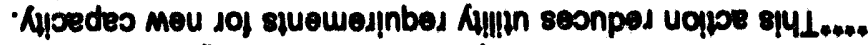

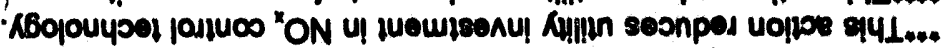

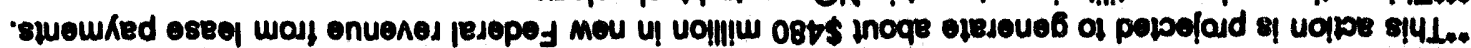

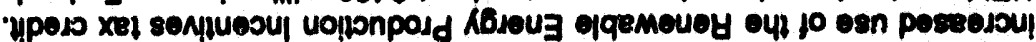

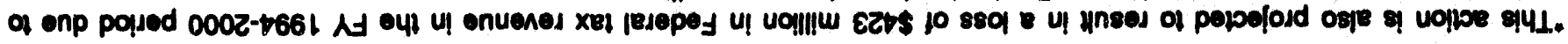

\begin{tabular}{|c|c|c|c|c|c|c|c|c|}
\hline 210 & 010 & $\angle 0^{\circ} 0$ & $80 \%$ & $10 \cdot 0$ & 60.0 & 10.0- & $\mathbf{E N}$ & $\begin{array}{l}\text { (nig uoilpapenb) } \\
\text { sbujnes fibloug }\end{array}$ \\
\hline Z20 & 801 & 6.6 & 98 & $2 \cdot L$ & 0.9 & $80^{\circ}$ & $B / U$ & $\begin{array}{c}\text { (eOIWW) } \\
\text { uopionpoy OHS }\end{array}$ \\
\hline \multicolumn{9}{|c|}{ 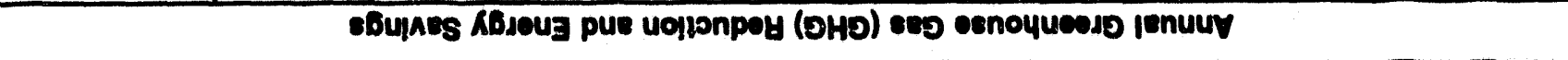 } \\
\hline $08 e^{\prime}$ LS & osts & $08 \times$ & o8zs & osts & 0815 & 0615- & 9 & mol \\
\hline monst- & $985^{-}$ & $9 s$ & 99 & Ss & $9 s$ & $9 s$ & 95 & (18) \\
\hline oots & ozls & 0915 & 0015 & 995 & $02 \$$ & 015 & is & $(0 \varepsilon+6 z)$ \\
\hline $\cos ^{6}$ LS & ooss & $008 s$ & 008 & $008 \$$ & coss & $0 \$$ & $0 \$$ & (82) \\
\hline cols & OSIS & 0915 & 0915 & OSIS & osis & ools & os & $(98)$ \\
\hline osts & 98t & 625 & 225 & 915 & 615 & 615 & os: & (sz) \\
\hline $400005-$ & osts- & osts- & osts- & 0915 & 0915 & $0<15$ & os & $(62)$ \\
\hline \multicolumn{9}{|c|}{ 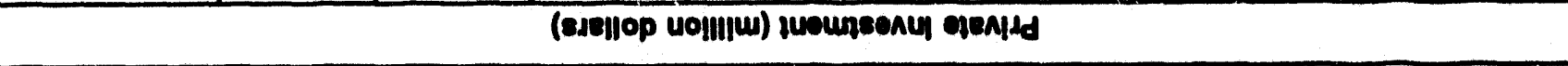 } \\
\hline ores & Qus & 845 & 6LS & oOLS & cots & 605 & 9 & ropol \\
\hline$a$ & os & os & 0 s & $0 s$ & $0 s$ & os & os & (16) \\
\hline is & is & is & is & 15 & IS & is & os & (08) \\
\hline 0 & os & $0 s$ & 05 & $0 s$ & $0 s$ & $0 s$ & $0 s$ & (62) \\
\hline onts & os & $0:$ & os & 05 & os & 25 & 25 & (88) \\
\hline 68 & $9 s$ & $9 s$ & 95 & $9 \$$ & $9 s$ & 95 & $8:$ & (LZ) \\
\hline .054 & $2 \angle S$ & ZLS & $2 \angle S$ & $2 \angle S$ & $2 \angle S$ & $2 \angle S$ & os & (92) \\
\hline 80 & os & $0:$ & $0 s$ & 225 & 225 & 815 & os & (92) \\
\hline 0 & os & os & 0 s & Os & $0 s$ & os & 05 & $(62)$ \\
\hline $\mathbf{0}$ & 05 & Os: & 0 s & 0 s & os & os: & Os & $(82)$ \\
\hline \multicolumn{9}{|c|}{ 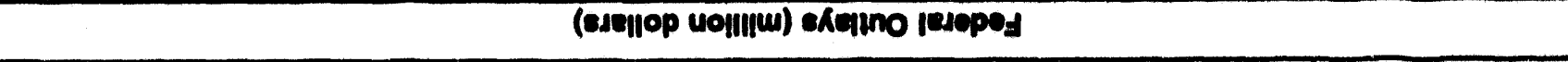 } \\
\hline$\frac{10 j 01}{0003 \text { test ad }}$ & $00021 d$ & $6081 \mathrm{AJ}$ & $8081 A d$ & Lest Ad & eseb Ad & sest ad & $\cos A \mathrm{~A}$ & werloy \\
\hline
\end{tabular}

suollov Ajddns Abjeug 'ES o19B1

(88 श98

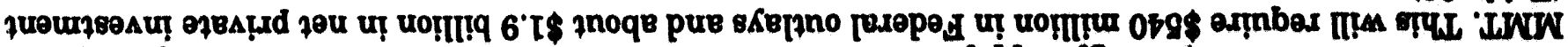

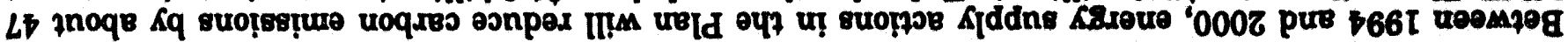




\section{Methane Reduction and Recovery Actions}

\section{(32) Expand "Natural Gas Star"}

Action Description: EPA will expand the Natural Gas Star program, which is a public/private partnerahip that reduces methane emissions by promoting cost-effective technologies and practices throughout the U.S. natural gas industry. Natural Gas Star provides technical assistance, implementation guidelines, and an information-sharing network for gas companies to achieve costeffective emissions reductions. The existing program, launched in March 1993, now includes 27 transmission and distribution companies. The expanded program targets production companies and transmission and distribution companies not currently in the program. It also calls for expediting management practices, including replacement of high-bleed pneumatics-a significant source of methane emisaiono-after 5 years rather than the current 7 years.

Analyais Description: A discounted cash flow analysis was used to determine the reductions in natural gas system emissions that could be achieved profitably. The analysis compares the value of gas (methane) saved to the cost of implementing the Natural Gas Star best management practices (BMP8). A detailed discussion of the cash flow analysis can be found in EPA's Report to Congress, Opportunities to Reduce Anthropogenic Methane Emissions in the United States. ${ }^{23}$

The cash flow analysis shows that about 25 percent of total emissions could be reduced profitably in 2000. This option assumes that expansion of the Natural Gas Star program will achieve reductions equivalent to 15 percent of total emissions in 2000 from this sector.

Input Assumptions: For the discounted cash flow analysis, natural gas prices in 2000 were assumed be $\$ 1.94$ per million cubic feet $(\mathrm{Mcf})$ at the wellhead; $\$ 2.45 / \mathrm{Mcf}$ to transmissions systems; and \$3.55/Mcf at the city gate for distribution systems. A real discount rate of 6 percent was used in the analysis. At prices used in the IDEAS simulations, this action would be even more attractive. Sensitivity analyses performed on both the discount rate and gas prices showed that a substantial change in gas price would be required to influence the results of the analysis.

\section{(33) Increase Stringency of Landfill Rules and (34) Expand Landfill Outreach Program}

Action Description: These actions are closely related and will be tracked together. There are more than 6,000 active landfills in the United States. The stringent Landfill Rules being promulgated by EPA will affect a fraction of these landfills (about 10 percent) and will also provide substantial reductions in methane emissions. Further reductions in greenhouse gas emissions can be achieved by promoting energy recovery by affected landfills rather than the minimum requirement of flaring the landfill gas.

The Landfill Outreach Program will work with State and local governments, the landfill and energy recovery industries, utilities, and others to overcome the barriers to profitable landfill gas recovery. The Outreach Program will target landfills affected by the Landfill Rules, as well as those not affected, that could profitably recover and use the methane they emit. Landfills in the second group have not installed energy recovery systems because they face a number of barriers, such as disincentives for utility purchases of landfill gas, artificially low prices, lack of information, regulatory constraints, and technological constraints. In the summer of 1994, EPA will work with State and local governments, utilities, and others in five key States to remove or lower State and Federal barriers that limit landfill energy recovery. In this process, EPA will identify landfills with potential for profitable energy recovery, and will take action to spur projects at those landfills. This program will be expanded over the following 2 years.

23. U.S. Environmental Protection Agency, Opportunities to Reduce Anthropogenic Methane Emissions in the United States, EPA-430-R-93-012 (Washington, DC, October 1993). 
Analyvis Description: The analysis conducted for the Landfill Rules will be available once the rules have been promulgated in final form. EPA considered a range of stringency level options for the final rules. The plan assumes that a 50-megagram threshold of the Landfill Rules will be applied. EPA has developed a discounted cash flow analysis that allows estimation of the methane emissions that could be reduced profitably with the Landfill Rules in place at various stringency levels. The model estimates that, with adoption of the toughest stringency level under consideration, an additional 5.5 percent of mothane emissions could be reduced profitably in 2000. Action (34) assumes that a Landfill Outreach program will lead to capture in $\mathbf{2 0 0 0}$ of $\mathbf{3 0}$ percent of the additional profitable reductions.

Input Assumptions: The model used for development of the Landfill Rules has been developed and refined over several years by EPA's Office of Air Quality Planning and Standards. Discussion of the model and inputs can be found in Air Emissions from Municipal Solid Waste Landfills-Background Information for Proposed Standards and Guidelines (EPA-450/3-90-011a, March 1991); Federal Register, Vol. 56, No. 104 (May 30, 1991), pp. 24468-24528; and Federal Register, Vol. 58, No. 117 (June 21, 1993), p. 33790 . Inputs used in the cash flow analysis include an 8-percent real discount rate and a year 2000 avoided cost rate of $\$ 0.05$ per $\mathrm{kWh}$. A detailed discussion of the cash flow analysis can be found in BPA's Report to Congress. ${ }^{24}$

\section{(35) Launch Coalbed Methane Outreach Program}

Action Description: The Coalbed Methane Outreach program will promote opportunities for costeffective emissions reductions by key coal companies and State agencies. It will help ensure that the EPACT provisions resolving coalbed methane ownership issues in the key States will achieve the potential reductions in those States. The program includes development of outreach materials (technology descriptions, sample Requests for Proposals, cost/benefit analyses, financing information), briefings for companies, States, utilities, and others, and demonstration projects. The outreach program would target approximately $\mathbf{5 0}$ of the country's most gaseous mines.

Analysis Description: A discounted cash flow analysis was used to determine the reductions in methane emissions from coal mining that could be achieved profitably. The analysis compared the value of recovered methane to the cost of recovery equipment and associated expenses. A detailed discussion of the cash flow analysis can be found in EPA's Report to Congress. ${ }^{25}$ The analysis assumed that the coalbed methane outreach program would achieve about one-third in 2000 of the total reductions that could be achieved profitably.

Input Assumptions: The cash flow analysis assumed a real gas price of $\$ 2.25 / \mathrm{Mcf}$ at the wellhead and a real discount rate of 6 percent in 2000. An extensive discussion of all the model assumptions can be found in EPA's Report to Congress (see especially Appendix 3A).

\section{(36) Expand RD\&D for Methane Recovery from Coal Mining}

Action Description: DOE will expand research, development, and dissemination (RD\&D) efforts to broaden the range of cost-effective technologies and practices for flaring and recovering methane associated with mining. Methods include lower cost, higher recovery drilling methods for pre-mining recovery of methane from coal seams (such as inert gas flooding), and methods for using in-mine degasification streams, such as enrichment for pipeline gas and electricity generation. The RD\&D effort also evaluates and demonstrates the use of fuel cells and other state-of-the-art technologies for waste methane utilization, transferring appropriate practices to the coal industry.

Analysis Description: EPA estimates that in 1988 about 9.0 to 12.6 MMTce of methane was released from the 60 mines classified as large and gassy ( $>0.5$ million tons of coal per year and $>500$ cubic feet of

24. U.S. Environmental Protection Agency, op. cit.

25. U.S. Environmental Protection Agency, op. cit. 
$\mathrm{CH}_{4}$ per ton of coal). Based on continuation of the current recovery level of 1.5 MMTce per year from underground coal mines, EPA estimates that 23.4 MMTce (range 19.2 to 30.0) of methane will be released from underground coal mines in 2000. Of this amount, EPA estimates that it is technically feasible to reduce emissions by 9.6 to 16.2 MMTce. Profitable reductions with current technology are estimated to be 8.4 MMTce (range 6.0 to 13.2), although there are barriers to implementation of these reductions. The outreach program in action (35) is estimated to result in implementation of about 26 percent of the midpoint of these profitable reductions - or a reduction of 2.2 MMTce per year-by 2000 .

The impact of Action 36 is to provide technologies that increase the total potential amount of methane that can be profitably recovered from about $6 \mathrm{MMTce}$ ( 8.4 less the 2.2 from Action $\# 35$ ) to about 10 MMTce. Action *36 also increases the economic attractiveness of recovery at mines that are already estimated to be at least marginally profitable with existing technologies. Of the total potential of 10 MMTce, about $15 \%$ or 1.5 MMTce per year assumed to be implemented with new techniques by 2000. This is equivalent to about $12 \%$ of current net emissions from gassy underground mines.

Input Assumptions: Analysis of amounts and costs for recovery of methane and generation of electricity (drilling, pipelines, electrical equipment, etc.) were based on nominal unit values described in EPA's Report to Congress. ${ }^{26}$ Revenues were computed at prices of $\$ 0.05$ per $\mathrm{kWh}$ (1991 dollars) for electricity and a variable world gas price starting in 1997 at $\$ 2.14$ per million Btu (1991 dollars). Projects had to be profitable at discount rates up to $10 \%$.

\section{(37) Expand RD\&D for Methane Recovery from Landfills}

Action Description: This action expands the DOE program of research, development, and demonstration that will remove or lower some of the current barriers to the economic recovery of landfill gas, a renewable energy source. Barriers to recovery include low methane generation rates, lack of data on performance of enhanced methods, air and water pollution regulations and concerns, and low or uncertain return on investments in recovery equipment. By demonstrating enhanced gas generation, efficient utilization and recovery techniques, and the environmental performance of these techniques, this action will improve cost-effective recovery of this underutilized energy resource. State and Federal coordination on siting and permitting of these technologies will facilitate development and deployment by reconciling the current prescriptive regulations with forward-looking environmentally sound development of a renewable energy source.

Analysis Description: The model used for analysis of the landfill options has been developed and refined by EPA's Office of Atmospheric Programs. Although not ideal for modeling the changes in landfill operations and gas generation envisioned in this action, it can approximate improvements in the system. The model simulated increases in gas collection efficiency, engine efficiency, and methane generation at landfills unaffected by the other landfill options. Based on these assumptions, the model estimated that about 200 additional landfills would become cost-effective for methane recovery, not counting landfills already regulated by EPA's Landfill Rule [action (33)] or already cost-effective for recovery. Only landfills opened before 2000 were considered. Of these potentially cost-effective landfills, about 40 percent were assumed to implement recovery of methane using enhanced techniques beginning in 1997. Investments, methane recovery, revenues from energy sales, and avoided methane emissions (based on normal emission profiles rather than enhanced generation rates) were computed for this hypothetical set of about 80 landfills. Based on these computations, methane reductions in 2000 were estimated. The reduction computations omitted several types of potential improvements in recovery performance, and thus could understate actual reductions.

Input Assumptions: Discussion of the algorithm and parameters used for analysis of the landfill options can be found in EPA's Report to Congress. ${ }^{27}$ The model runs simulated a 5-percent increase in gas

26. U.S. Environmental Protection Agency, op. cit.

27. U.S. Environmental Protection Agency, op. cit. 
collection efficiency, a 25-percent increase in engine efficiency, and a 10-percent increase in methane generation. The changes resulting from this action were examined only at landfills unaffected by the other landfill options $(1,624$ out of more than 6,000$)$-i.e., those where gas collection was least likely to be cost-effective. Eighty landfills were assumed to actually implement methane recovery using advanced techniques by 2000 . Those 80 landfills accounted for the reductions reported in this action. Inputs used in the cash flow analysis include an 8-percent real discount rate and a year 2000 avoided cost rate of $\$ 0.05$ per kWh (1991 dollars).

\section{(38) Expand AgStar Partnershlp Program with Llvestock Producers}

Action Description: AgSTAR is a voluntary pollution prevention program with the livestock industry. The AgSTAR program encourages dairy and swine facilities to adopt animal manure best management practices that profitably manage animal manure, protect surface and groundwater, and reduce fertilizer costs. The AgSTAR program overcomes a number of barriers that currently hinder the more widespread use of on-farm energy recovery technologies. These barriers include farmers' lack of information about the profit potential of methane recovery options and their memory of projects launched during the 1970s that failed. Under the program, producers commit to survey their facilities to identify profitable options for capture and use of methane for on-farm power usage.

Analysis Description: A discounted cash flow analysis was used to determine the reductions in methane emissions from animal waste systems that could be achieved profitably. The value of energy produced from the methane, used to meet on-farm energy needs, was compared to the cost of recovery equipment and related expenses. A detailed discussion of the cash flow analysis can be found in EPA's Report to Congress. $^{28}$

The cash flow analysis shows that 3.0 to 6.0 MMTce could be recovered profitably from dairy and swine farms in 2000. This option for expansion of the AgSTAR program anticipates additional reductions equivalent to 35 percent of total profitable reductions in 2000.

Input Assumptions: A 10-percent real discount rate and State average residential and commercial electricity prices $^{20}$ were used for the discounted cash flow analyses. The energy price assumptions are documented in EPA's Report to Congress.

\section{(39) Improve Ruminant Productivity and Product Marketing}

Action Description: Dairy and beef cattle are responsible for more than 30 MMTce of methane emissions per year. The program will address the six main options for reducing emissions through improved management at the farm level. The options are as follows: (1) improved nutrition though mechanical and chemical feed processing and improved grazing management, (2) improved nutrition through strategic supplementation as part of pasture and range management, (3) production-enhancing agents to improve feed efficiency, (4) improved production through improved genetic characteristics, (5) improved production efficiency through improved reproduction, and (6) controlling disease. The program will also build on existing efforts to remove market barriers to, and create incentives for, increased production of milk and meat with lower fat content. Such products create less methane per unit of product than do higher-fat products.

Analysis Description: An analysis was performed of economically attractive technological and management improvement options that would increase animal productivity and therefore reduce methane emissions per unit of product. As productivity increases, emissions per unit of product are reduced, because maintenance feed requirements are spread out over a larger amount of production and/or because

28. U.S. Environmental Protection Agency, op. cit.

29. Energy Information Administration, Electric Sales and Revenue 1989, DOE/ELA-0540(89)(Washington, DC, Apr. 1991). 
feed conversion efficiency is improved. The options are cost-effective principally because they reduce costs per unit of product. A detailed discussion of the analysis can be found in EPA's Report to Congress. ${ }^{30}$

Input Assumptions: The assumed effectiveness of the various options for reducing methane emissions per unit of product is based on recent field studies and experimental data. The estimate of total costeffective emissions reductions for each option reflects the extent to which use of each option could be increased incrementally to current practices, considering existing trends. The extent to which each of the reduction options considered in the analysis (e.g., improving cow-calf productivity, use of bovine somatotropin) is assumed to be cost-effective is based on existing industry studies and expert input (see the EPA Report to Congress referenced above for a description and list of the existing studies). Based on this data, a range of penetration rates was developed for each of the options considered. The emissions reductions achievable from implementation of each of the options was then estimated based on factors for emissions per unit of product developed by EPA (see Anthropogenic Methane Emissions in the United States: Estimates for 1990, EPA 430-R-93-003, April 1993, for a detailed discussion of the emissions factors). The Plan assumes that this action will achieve 25 percent of the cost-effective reductions described in EPA's Report to Congress in 2000.

\section{Methane Reduction and Recovery Actions Summary}

Between 1994 and 2000, methane recovery and reduction actions in the Plan will reduce greenhouse gas emissions by 36 MMTce. This will require $\$ 109$ million in Federal outlays and about $\$ 460$ million in net private investment (Table 34).

\section{Hydrofluorocarbon (HFC), Perfluorocarbon (PFC) and Nitrous Oxide $\left(\mathrm{N}_{2} \mathrm{O}\right)$ Reduction Actions}

\section{(40) Narrow Use of Chemicals with High Global Warming Potentlal (GWP), Using the Clean Air Act and Production Stewardship to Reduce Emissions}

Action Description: EPA will restrict the use and emission of high Global Warming Potential (GWP) chemicals by encouraging product stewardship for long-lived gases and by using Section 612 of the Clean Air Act Amendments of 1990 to narrow uses of high-GWP chlorofluorocarbon (CFC) substitutes, such as HFCs and $\mathrm{PFCs}_{8}$, based on an overall risk assessment.

ERA will create a partnership program with manufacturers of long-lived HFCs and PFCs. Under the partnership program, companies will commit to not selling those chemicals for emissive uses and to ensuring that users of long-lived gases handle the materials in an environmentally responsible manner-for instance, by capturing and destroying the gas rather than emitting it into the atmosphere.

Analysis Description: A baseline analysis was conducted to determine the expected increase in emissions of $\mathrm{HFCs}$ and PFCs in 2000 and 2010. The analysis consisted of using a vintaging analysis to estimate the stock of equipment in each end use, chemical use per piece of equipment, equipment lifetimes, and emission rates from each piece of equipment. The baseline analysis was used to identify chemicals and uses with high GWP and emission rates.

The analysis was conducted by sector, and the expected use of each chemical was aggregated. Substitution scenarios were analyzed, describing the chemicals that will replace $\mathrm{CFCs,}$ halons, and hydrogenated fluorocarbons (HCFCs) when they are phased out under the Copenhagen Amendments to

30. U.S. Environmental Protection Agency, op. cit. 
Table 34. Methane Recovery and Reduction Actions

\begin{tabular}{|c|c|c|c|c|c|c|c|c|}
\hline Action & FY 1904 & FY 1905 & FY 1906 & FY 1897 & FY 1998 & FY 1909 & FY 2000 & $\begin{array}{c}\text { FY } 1909-2000 \\
\text { Total }\end{array}$ \\
\hline \multicolumn{9}{|c|}{ Federal Outlays (million dollare) } \\
\hline (32) & \$o & $\$ 1$ & $\$ 1$ & $\$ 1$ & $\$ 1$ & $\$ 1$ & $\$ 2$ & $\$ 7$ \\
\hline (33) & $\$ 0$ & $\$ 0$ & $\$ 0$ & $\$ 0$ & $\$ 0$ & $\$ 0$ & $\$ 0$ & $\$ 0$ \\
\hline (34) & $\$ 0$ & $\$ 1$ & $\$ 1$ & $\$ 1$ & $\$ 1$ & $\$ 2$ & $\$ 2$ & $\$ 8$ \\
\hline (35) & $\$ 1$ & $\$ 1$ & $\$ 1$ & $\$ 1$ & $\$ 2$ & $\$ 2$ & $\$ 2$ & $\$ 10$ \\
\hline (36) & $\$ 1$ & $\$ 3$ & $\$ 4$ & $\$ 4$ & $\$ 3$ & $\$ 1$ & $\$ 1$ & $\$ 17$ \\
\hline (37) & $\$ 0$ & $\$ 1$ & $\$ 2$ & $\$ 2$ & $\$ 2$ & $\$ 1$ & $\$ 1$ & $\$ 9$ \\
\hline (38) & $\$ 2$ & $\$ 4$ & $\$ 4$ & $\$ 4$ & $\$ 4$ & $\$ 4$ & $\$ 5$ & $\$ 28$ \\
\hline (39) & $\$ 1$ & $\$ 2$ & $\$ 3$ & $\$ 4$ & $\$ 6$ & $\$ 6$ & $\$ 6$ & $\$ 20$ \\
\hline Total & $\$ 6$ & $\$ 12$ & $\$ 16$ & $\$ 18$ & $\$ 20$ & $\$ 18$ & $\$ 19$ & $\$ 109$ \\
\hline \multicolumn{9}{|c|}{ Private investmont (million dollers) } \\
\hline (32) & $\$ 0$ & $\$ 1$ & $\$ 5$ & $\$ 10$ & $\$ 10$ & $\$ 17$ & $\$ 17$ & $\$ 60$ \\
\hline (33) & $n / a$ & $n / a$ & $n / a$ & $n / a$ & $n / a$ & $n / a$ & $n / a$ & $\mathrm{n} / \mathrm{a}$ \\
\hline (34) & so & $\$ 1$ & $\$ 6$ & $\$ 23$ & $\$ 80$ & $\$ 35$ & $\$ 35$ & $\$ 180$ \\
\hline (35) & $\$ 0$ & $\$ 25$ & $\$ 15$ & $\$ 10$ & $\$ 10$ & $\$ 10$ & $\$ 10$ & $\$ 80$ \\
\hline (36) & so & $\$ 0$ & $\$ 0$ & $\$ 36$ & $\$ 55$ & $\$ 21$ & $\$ 89$ & $\$ 200$ \\
\hline (37) & $\$ 0$ & $\$ 0$ & $\$ 0$ & $\$ 17$ & $\$ 38$ & $\$ 42$ & $\$ 102$ & $\$ 200$ \\
\hline (38) & $\$ 0$ & $\$ 2$ & $\$ 9$ & $\$ 20$ & $\$ 30$ & $\$ 40$ & $\$ 40$ & $\$ 140$ \\
\hline (39) & $n / a$ & $n / a$ & $n / a$ & $\mathrm{n} / \mathrm{a}$ & $n / a$ & $n / a$ & $n / a$ & n/a \\
\hline Total & $\$ 0$ & $\$ 29$ & $\$ 34$ & $\$ 63$ & $\$ 130$ & $\$ 100$ & 9500 & $\$ 460$ \\
\hline \multicolumn{9}{|c|}{ Annual Greonhouse Ges (GHG) Reduction } \\
\hline $\begin{array}{l}\text { GHG Reduction } \\
\text { (MMTco) }\end{array}$ & 0 & 0 & 0.5 & 1.4 & 7.0 & 11.2 & 16.3 & 36 \\
\hline
\end{tabular}

Notes: Totals may not equal sum of components due to independent rounding. The budget authority numbers shown in this table reflect the requests made by the various agencies for project funding at the time the Plan was announced; they do not necessarily indicate the actual appropriation of funds.

the Montreal Protocol. The scenarios were based on estimated market penetration and the number of years it might take to fully irplement a substitute.

As part of the regulatory process for Section 612, risk assessments were conducted for each end-use sector. The analysis evaluated all the environmental and health factors attributed to each CFC substitute. EPA has the authority to restrict uses of $\mathrm{HFC}_{s}$ and $\mathrm{PFCs}$ if other alternatives to ozonedepleting chemicals exist and pose less risk to human health and the environment.

Input Assumptions: The final rule on Section 612 is scheduled to be released under a court order in February 1994. The final rule will contain initial decisions to narrow uses, institute voluntary measures 
to reduce emissions, and list some alternatives as unacceptable. Once the final rule is promulgated, continued decisionmaking will occur through submissions of new applications, the petition process, and a quarterly update of the acceptable and unacceptable list. Complete documentation of the analysis for this action is part of the regulatory docket that will be available at the time of issuance of the final rule.

\section{(41) Create Partnerships with Manufacturers of HFC-22 to Eliminate HCFC-23 Emissions}

Action Description: This program is a partnership program with manufacturers of HCFC-22 to develop and implement processing practices or technologies to reduce HFC-23 as a byproduct of HCFC-22 production where it is technically feasible and cost-effective. Currently, 2 to 4 percent of HCFC-22 production is released as HFC-23, a potent greenhouse gas. Participating manufacturers agree to reduce emissions of HFC-23 to 50 percent of 1990 emissions.

Analysis Description: Individual manufacturers were consulted on their current emission levels and potential for making reductions. The industry trade association, the Alliance for Responsible CFC Policy, representing all five of the current manufacturers in the United States, agreed that the companies will work in partnership with EPA to make a 50-percent reduction from the current baseline estimate for 2000. The emission reductions were therefore based on the judgment of industry experts and the companies' letter of intent to make HFC-23 reductions.

Input Assumptions: Based on consultations with manufacturers and letters of intent, HFC-23 emissions will be reduced 50 percent below year 2000 baseline levels.

\section{(42) Launch Partnership with Aluminum Producers to Reduce Emissions from Manufacturing Processes}

Action Description: This program will encourage aluminum-producing companies to reduce emission of carbon tetrafluoride $\left(C F_{4}\right)$ and carbon hexafluoride $\left(\mathrm{C}_{2} \mathrm{~F}_{8}\right)$ where technically feasible and cost-effective. Because the factors that cause these emissions result in an efficiency loss, a reduction in emissions has concurrent production benefits. This option includes support of research efforts, such as developing a better understanding of emissions and conirol options.

Analysis Description: EPA estimates that reductions in emissions of $\mathrm{CF}_{4}$ and $\mathrm{C}_{2} \mathrm{~F}_{6}$ from aluminum smelting could be reduced by 30 to 60 percent by 2000 . These emissions occur during "anode effects," the frequency and duration of which can be reduced through operational and technological changes in the aluminum production process. EPA is working with the aluminum industry to improve understanding of the relationship between anode effects and emissions, and to develop reduction approaches.

Input Assumptions: The analysis assumed that the operational and technological changes needed to achieve a 45-percent reduction in emissions would be cost-effective and not harm the aluminum companies' competitiveness. Baseline emissions are based on an emissions factor of $0.6 \mathrm{~kg}$ of $\mathrm{CF}_{4}$ and 0.06 $\mathrm{kg}$ of $\mathrm{C}_{2} \mathrm{~F}_{6}$ per metric ton of aluminum produced.

\section{HFC, PFC, and $\mathrm{N}_{2} \mathrm{O}$ Reduction Actions Summary}

Between 1994 and 2000, HFC, PFC, and $\mathrm{N}_{2} \mathrm{O}$ reduction actions in the Plan will reduce greenhouse gas emissions by almost 41 MMTce. This will require $\$ 16$ million in Federal outlays (Table 35). 
Table 35. HFC, PFC, and $\mathrm{N}_{2} \mathrm{O}$ Reduction Actlons

\begin{tabular}{|c|c|c|c|c|c|c|c|c|}
\hline Aotion & FY 1894 & FY 1905 & FY 1908 & FY 1097 & FY 1808 & FY 1998 & FY 2000 & $\begin{array}{c}\text { FY } 1904-2000 \\
\text { Total }\end{array}$ \\
\hline \multicolumn{9}{|c|}{ Foderal Outloys (million dollars) } \\
\hline$(40)$ & $\$ 1$ & $\$ 2$ & $\$ 1$ & $\$ 1$ & $\$ 1$ & $\$ 1$ & $\$ 1$ & $\$ 9$ \\
\hline (41) & $\$ 0$ & $\$ 1$ & $\$ 1$ & $\$ 1$ & $\$ 0$ & $\$ 0$ & $\$ 0$ & \$4 \\
\hline (42) & $\$ 0$ & $\$ 1$ & $\$ 1$ & $\$ 1$ & $\$ 0$ & $\$ 0$ & $\$ 0$ & $\$$ \\
\hline (17) & \multicolumn{8}{|c|}{ See action (17), Table 26} \\
\hline Total & $\$ 1$ & $\$ 4$ & $\$ 4$ & $\$ 3$ & $\$ 1$ & $\$ 1$ & $\$ 1$ & $\$ 16$ \\
\hline \multicolumn{9}{|c|}{ Annual Greonhouse Gas (GHG) Reduction } \\
\hline $\begin{array}{c}\text { GHG Roduction } \\
\text { (MMTCo) }\end{array}$ & 0.1 & 1.2 & 2.5 & 5.9 & 7.8 & 10.1 & 13.0 & 40.6 \\
\hline
\end{tabular}

Notes: Totals may not equal sum of components due to independent rounding. The budget authority numbers shown in this table reflect the requests made by the various agencies for project funding at the time the Plan was announced; they do not necessarily indicate the actual appropriation of funds.

\section{Forestry Actions}

\section{(43) Reduce the Depletion of Nonindustrlal Private Forests}

Action Description: USDA will provide technical assistance to nonindustrial private forest landowners to aid them in making silviculturally and financially sound timber harvesting decisions that are consistent with landowner objectives and good forest stewardship. Large increases in the ability of forests to capture and store carbon can be achieved through reductions in harvesting practices that leave forests in an understocked and depleted condition. USDA Forest Service will carry out this action in cooperation with State Foresters and private consulting foresters who will prepare stand evaluations that describe the owner's timber (tree species composition, age, stocking, growth rate, and approximate volume and value) and recommend management options for the next 10 years.

Analysis Description: Costs and carbon yields of improved land management are based on Costs of Sequestering Carbon Through Tree Planting and Forest Management in the United States by Moulton and Richards (USDA Forest Service General Technical Report WO-58, December 1990) with updating as described in Costs of Creating Carbon Sinks in the U.S. by Richards, Moulton, and Birdsey (IFA Carbon Dioxide Disposal Symposium, Oxford, England, March 29-31, 1993). The application of these studies to this action is described in Improved Management and Harvesting Practices on Nonindustrial Private Timberlands, presented by Moulton at the White House Conference on Global Climate Change, Washington, DC, July 15, 1993.

This action will be carried out through the established USDA Forest Service-State Forester delivery system, which has provided on-the-ground forestry assistance to private forest landowners for over 60 years.

Input Assumptions: Nonindustrial private landowners control 60 percent of U.S. timberland. Overharvesting with adverse effects on carbon sequestration and storage occurs on over 500,000 acres each year ( 0.2 percent). Overharvesting will be reduced as a result of the recommendations provided to landowners. This action will be phased-in, beginning with 18,000 acres in 1994, and rising to the full 
program level of 180,000 acres annually in 1998 . The program will include a total of over 800,000 acres by 2000 .

Costs of preparing recommendations for landowners are based on the current costs of stand analysis under the Forest Stewardship Program and Rural Forestry Assistance Program, which provided assistance to over 19,000 private owners on almost 3 million acres of forest land in 1993.

\section{(44) Accelerate Tree Planting In Nonindustrial Private Forests}

Action Description: This action constitutes an expansion of USDA Forest Service programs that promote tree planting by nonindustrial private forest landowners through the provision of on-the-ground technical assistance and the incentive of cost share assistance. Since 1936, more than 7 million acres of trees have been planted on nonindustrial private lands under the Agriculture Conservation Program, and, since 1974, another 3 million acres under the Forestry Incentives Program.

This action focuses on increased tree planting on poorly stocked and nonstocked nonindustrial private forest land $t=233,000$ acres within 5 years. Technical assistance and up to 75 percent Federal costsharing will be provided by the USDA Forest Service in cooperation with the respective State foresters. This action will be implemented through the existing Stewardship Incentive Program.

Trees are very efficient in removing carbon dioxide from the atmosphere and depositing it as solid carbon in wood-which is about one-half carbon on a dry weight basis-and in organic matter in the soil, forest floor surface litter, and understory plants.

Analysis Description: Costs and carbon yields for this action are based on Costs of Sequestering Carbon Through Tree Planting and Forest Management in the United States by Moulton and Richards (USDA Forest Service General Technical Report WO-58, December 1990) with updating as described in Costs of Creating Carbon Sinks in the U.S. by Richards, Moulton, and Birdsey (IEA Carbon Dioxide Disposal Symposium, Oxford England, March 29-31, 1993). The application of these studies to this action is described in Accelerated Tree Planting in Nonindustrial Private Forests, presented by Moulton at the White House Conference on Global Climate Change, Washington, DC, July 15, 1993.

Input Assumptions: This action begins with the planting of 23,000 acres of additional trees in 1994 and grows to an annual level of 233,000 acres in the years 1998-2000. The trees are distributed regionally in the U.S. based on experience with current programs, and the analysis reflects regional differences in costs, tree species and growth rates. Costs and carbon yields are adjusted for expected plantation losses and lagged to account for the phase-in period, the projected rate of growth and replanting.

With respect to carbon, the process of photosynthesis, whereby carbon dioxide is removed from the air by trees and other green plants, and the carbon content of wood are matters of scientific fact. The dynamics of soil carbon are not as well known, since this is a comparatively new area of study, and extrapolations must be made from documented points to provide estimates for various soil types, tree species, and temperature and moisture regimes. Hence, the soil carbon estimates used were deliberately conservative because of the larger error bounds associated with the estimates.

\section{Forestry Actlons Summary}

Between 1994 and 2000, forestry actions in the Plan are expecter to sequester an additional 35 MMT of carbon. This will require $\$ 76$ million in Federal outlays and about $\$ 40$ million in net private investment (Table 36). 
The Climate Change Action Plan: Technical Supplement

Table 36. Foreatry Actlons

\begin{tabular}{|c|c|c|c|c|c|c|c|c|}
\hline Action & FY 1994 & FY 1905 & FY 1990 & FY 1997 & FY 1008 & FY 1900 & FY 2000 & $\begin{array}{c}\text { FY } \begin{array}{c}1904-2000 \\
\text { Total }\end{array} \\
\end{array}$ \\
\hline \multicolumn{9}{|c|}{ Fodoral Outlays (million dollaro) } \\
\hline (43) & so & so & so & $\$ 1$ & $\$ 1$ & $\$ 1$ & $\$ 1$ & $\$ 4$ \\
\hline (44) & $\$ 2$ & $\$ 3$ & $\$ 6$ & $\$ 13$ & $\$ 16$ & $\$ 16$ & $\$ 16$ & $\$ 71$ \\
\hline (16) & \multicolumn{8}{|c|}{ See action (16), Table 26} \\
\hline (9) & \multicolumn{8}{|c|}{ See action (9), Table 24} \\
\hline Total & 32 & $\$$ & $\$ 7$ & $\$ 13$ & $\$ 17$ & $\$ 17$ & $\$ 17$ & 970 \\
\hline \multicolumn{9}{|c|}{ Private Invostment (million dollare) } \\
\hline (43) & so & $\$ 0$ & 50 & so & so & so & so & 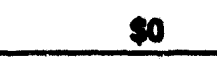 \\
\hline (44) & $\$ 1$ & $\$ 2$ & $\$ 4$ & $\$ 7$ & $\$ 9$ & $\$ 9$ & $\$ 9$ & $\$ 40$ \\
\hline (16) & \multicolumn{8}{|c|}{ See action (16), Table 26} \\
\hline (9) & \multicolumn{8}{|c|}{ Soe action (9), Table 24} \\
\hline Total & $\$ 1$ & $\$ 2$ & 84 & $\$ 7$ & $\$ 9$. & $\$ 9$ & $\$ 9$ & $\$ 40$ \\
\hline \multicolumn{9}{|c|}{ Annual Greonhouse Ose (GHa) Reduction } \\
\hline $\begin{array}{l}\text { GHG Redustion } \\
\text { (MMTco) }\end{array}$ & 0.4 & 0.8 & 2.7 & 5.5 & 7.4 & 8.6 & 10.0 & 35.3 \\
\hline
\end{tabular}

Notes: Totals may not equal sum of components due to independent rounding. The budget authority numbers shown in this table reflect the requests made by the various agencies for project funding at the time the Plan was announced; they do not necessarily indicate the actual appropriation of funds. 


\section{Integrated Analysis of Energy-Related Actions}

The Integrated Dynamic Energy Analysis Simulation (IDEAS) model is a simulation of U.S. energy supply and demand designed to project the long-term behavior of the U.S. energy system. The model provides detailed projections of U.S. energy supply, demand, prices, and costs under alternative energy policy assumptions. A more detailed description of the IDEAS model is provided in Appendix $\mathbf{E}$.

\section{Energy Projections: Administration Baseline and Combined Policy Cases}

In the Administration Baseline, primary energy consumption is projected to increase by 9.3 quadrillion Btu, or 11 percent, from 1990 to 2000 . $^{31}$ The largest increases are for natural gas and petroleum consumption, at 3.5 and 3.1 quadrillion Btu, respectively (Figure 12). Coal consumption is projected to increase by only 0.3 quadrillion Btu over the decade. On a percentage basis, during the 1990 to 2000 period, renewables are projected to have the fastest growth at 27 percent; natural gas is second fastest at 18 percent.

Figure 12. Primary Energy Consumption, 1990 and 2000

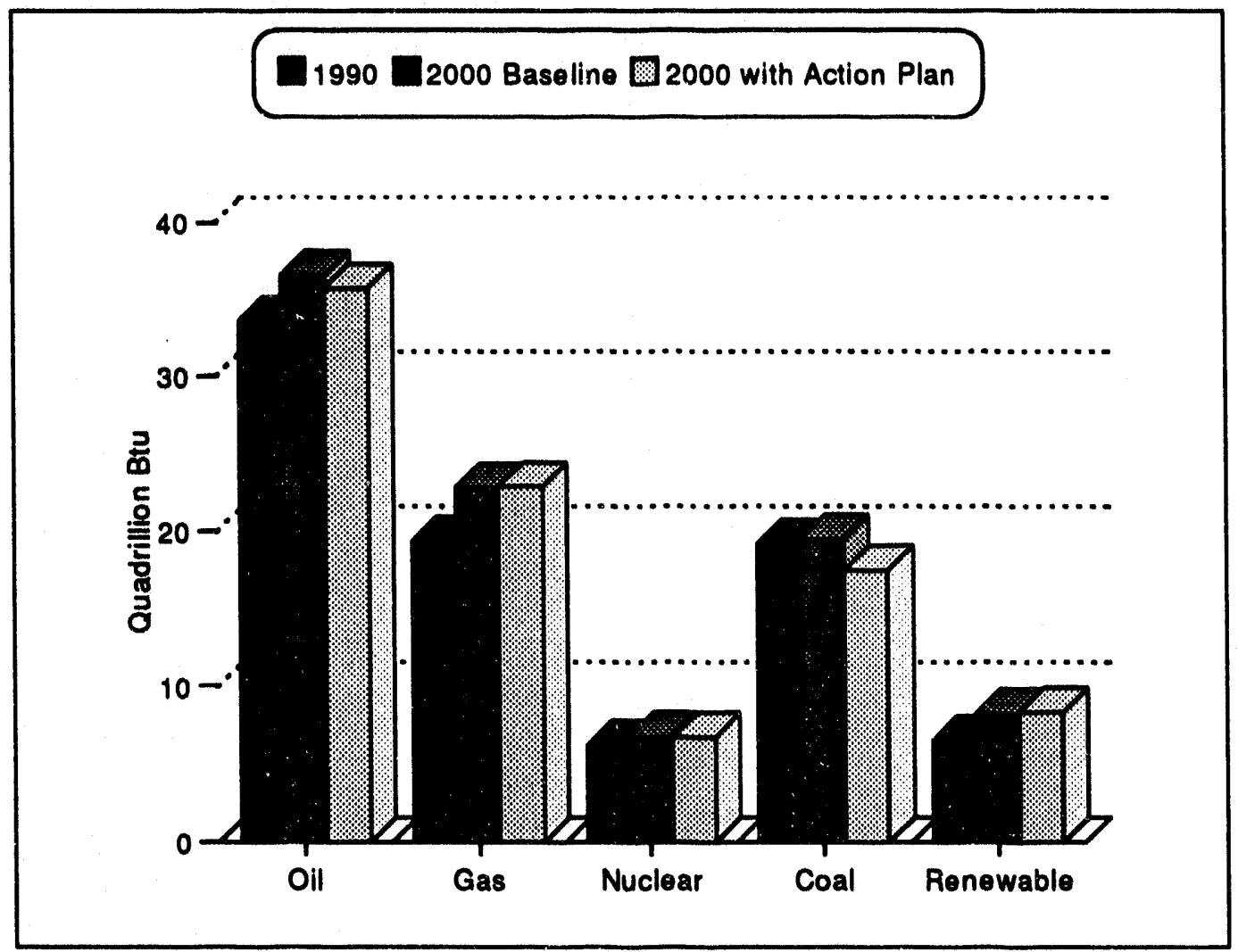

31. This represents an increase of 8.4 quadrillion $B$ tu, or 10 percent, from 1992 , as estimated from the Energy Information Administration's Monthly Energy Review, with an adjustment for renewable energy. 
With the Climate Change Action Plan (the Plan) in effect, as represented by the Combined Policy Case, primary consumption is projected to increase by only 6.6 quadrillion Btu, or 8 percent, from 1990 to 2000 . Despite significant gains in energy efficiency, consumption of most fuels increases between 1990 and 2000 (Figure 13). Reductions from the projected Administration Baseline levels of energy use in 2000 are not evenly spread across fuels. The use of coal, the most carbon-intensive of the fossil fuels, decreases the most, falling by 2.0 quadrillion (10 percent) in 2000 compared with the Baseline. In contrast, renewables and natural gas increase by 0.06 quadrillion Btu ( 0.7 percent) and 0.05 quadrillion Btu ( 0.2 percent) in 2000, respectively relative to their Administration Baseline levels.

Figure 13. Dellvered Energy Consumption, 1990 and 2000

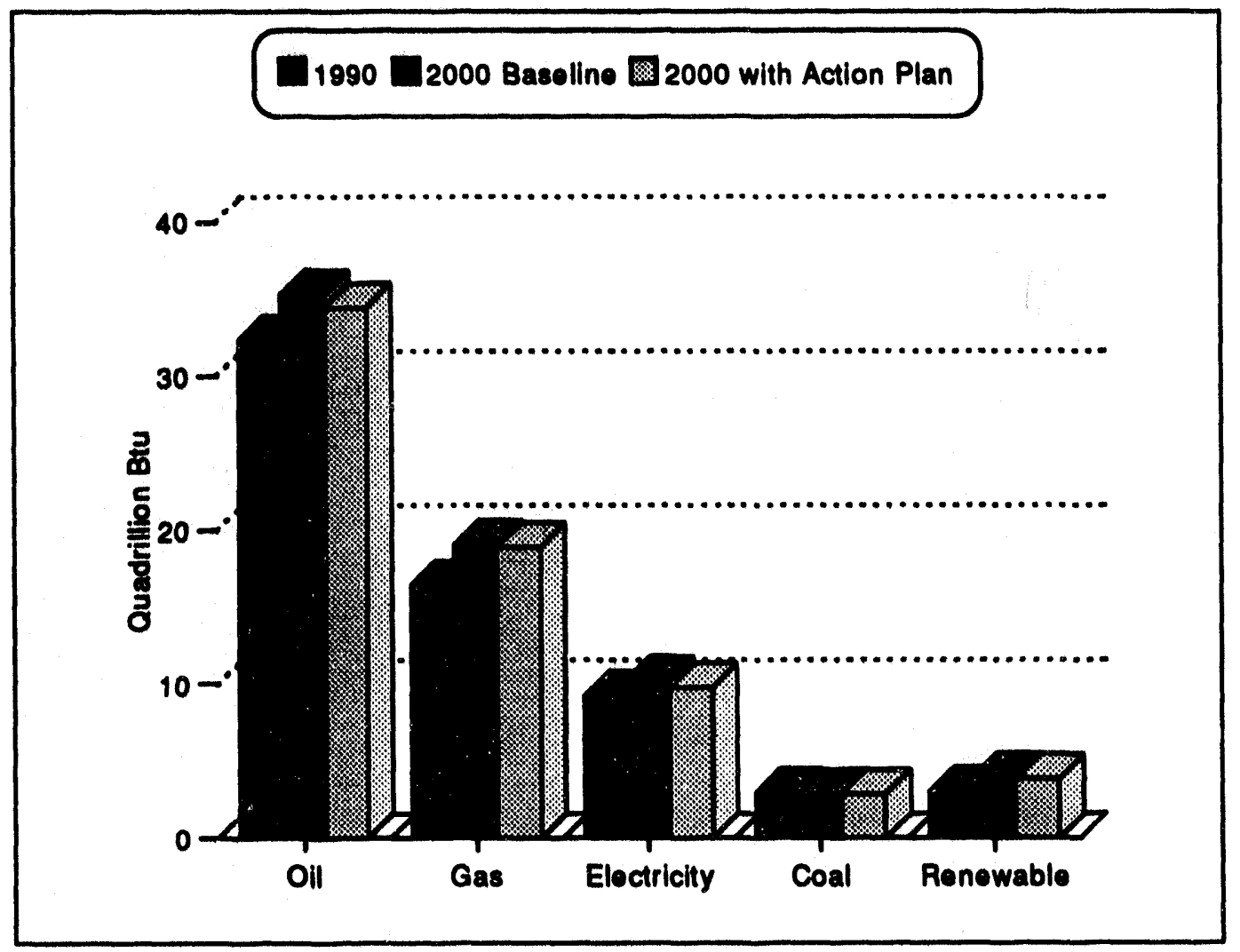

Electricity conservation accounts for roughly one-third of the delivered energy savings in the Plan. In the Baseline, electricity sales are projected to increase at 1.0 percent per year from 1990 to 2000; the Plan projects growth of 0.5 percent per year. Although not specifically represented in the modeling projections, the Utility Climate Challenge Program to voluntarily reduce emissions increases the likelihood that the projected electricity efficiency improvements envisioned by the Plan will occur.

In absolute terms, the largest reductions in primary energy use relative to the Baseline occur in the industrial and residential sectors -1.0 and 0.8 quadrillion Btu, respectively (Figure 14). In percentage terms, the largest savings occur in the residential sector (4.2 percent) and the commercial sector (3.9 percent).

With the Plan in effect, total utility energy use is projected to decrease by 1.7 quadrillion Btu, or 5.0 percent, in 2000 (Figure 15). This decrease accounts for 62 percent of the total primary energy reduction expected under the Plan. Changes in coal consumption make up virtually all of this reduction. Use of natural gas and renewable fuels by utilities is projected to increase slightly. Total utility fuel use decreases, because many actions in the Plan promote increased efficiency in the use of electrical energy, 
Figure 14. Increase In Primary Energy Consumption, 1990-2000

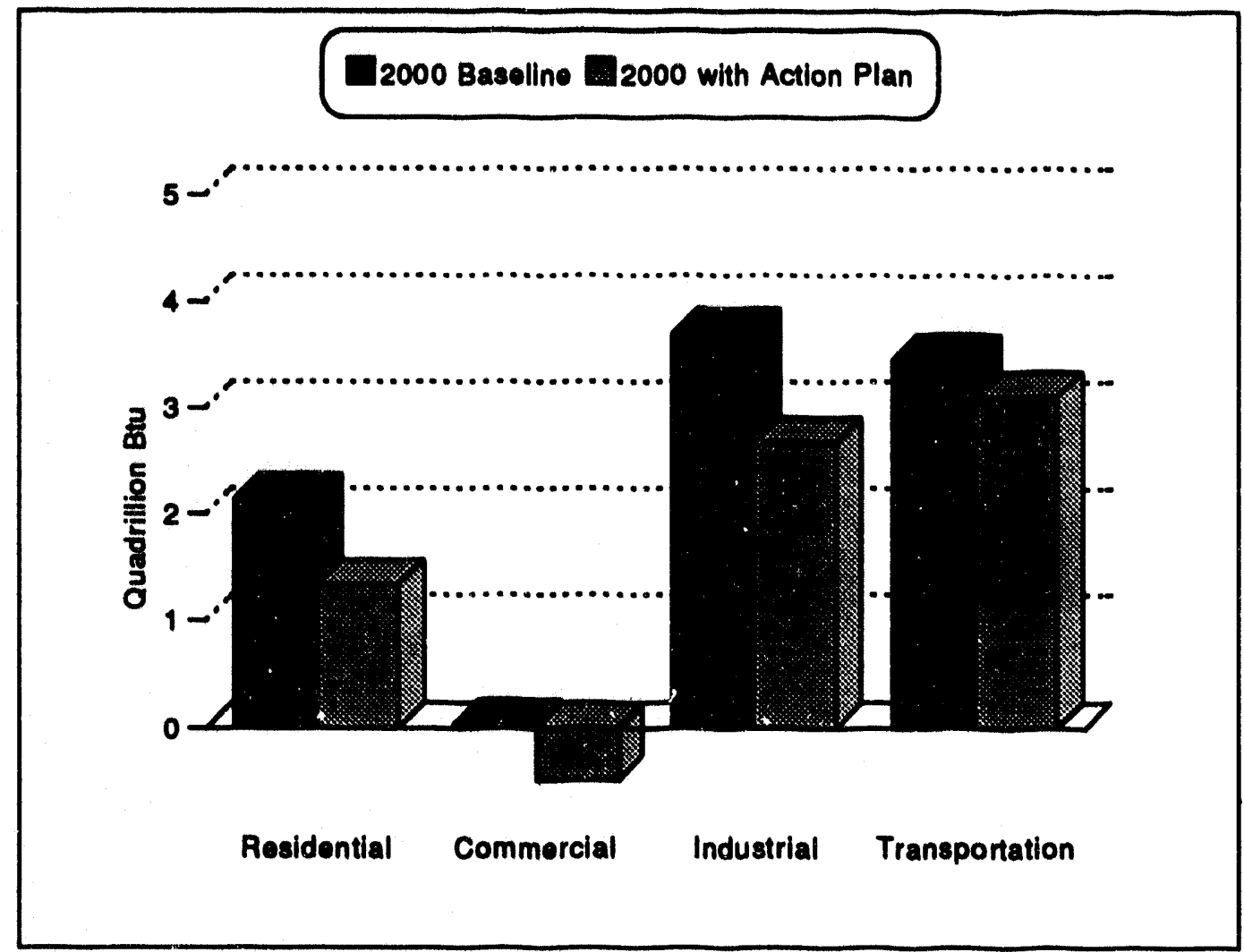

Flgure 15. Utility Energy Consumption, 1990 and 2000

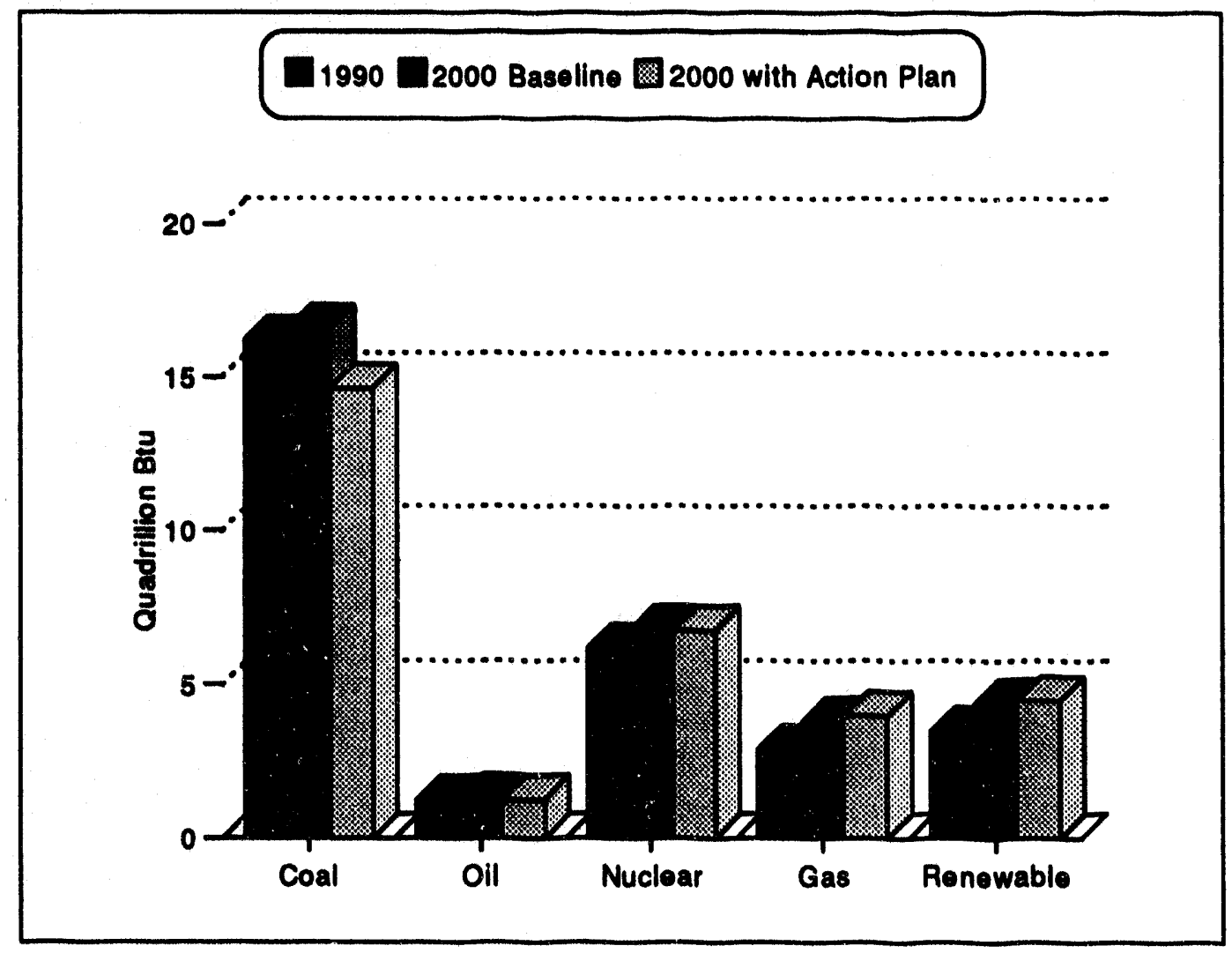


which results in lower electricity sales. As sales are reduced from the levels projected in the Administration Baseline, existing plants are operated at lower capacity factors. In addition, little new capacity construction is required over the next decade; therefore, there is little change in capacity levels across cases.

The average real price of crude oil in the Administration Baseline is projected to increase by 3.0 percent annually between 1992 and 2000. This increase returns the price of oil to its 1990 level (before the Iraqi invasion of Kuwait). Real wellhead prices for natural gas are projected to increase by 3.4 perceni per year from 1990 to 2000, and real minemouth prices for coal are projected to increase by 1.6 percent per year. Electricity prices are projected to remain roughly constant, increasing by only 0.4 percent per year in real terms.

The Baseline price projections are affected by the implementation of the Plan, which significantly alters demand. Oil prices, which are determined by the world market, are only 0.9 percent lower in 2000 in the Combined Policy Case than in the Administration Baseline. Increased demand for natural gas over the 1990 to 2000 period leads to increased wellhead prices. In 2000 , the wellhead price is projected to be 2.4 percent higher in the Combined Policy Case than in the Baseline. On the other hand, coal prices in 2000 are 1.6 percent lower than in the Baseline, as a result of reduced demand. For electricity, which is subject to cost-based regulation, decreased demand leads to higher prices in 2000, because the fixed costs associated with generation assets are spread over less kilowatthour sales. In 2000, the average real electricity price is 2.4 percent higher in the Combined Policy Case than in the Administration Baseline.

Carbon emission reductions result from reduced energy consumption and a shift to less carbon-intensive fuels. As noted in Chapter 1, the Plan is projected to reduce carbon emissions from energy sources in 2000 by 66 million metric tons (MMT) relative to the Baseline. Everi with this reduction, however, carbon emissions in 2000 are projected to be 41 MMT higher than in 1990. The Plan is able to return total greenhouse gas emissions to 1990 levels because it reduces all other sources (or increases sinks) of greenhouse gas emissions in 2000 by $\mathbf{4 3}$ million metric tons carbon equivalent (MMTce) below their 1990 level.

The Plan also alters the pattern of energy-related carbon emissions among end-use sectors (Figure 16). The largest reductions occur in the industrial sector, while the smallest occur in the transportation sector. By end-use fuel, the greatest reductions are in electricity carbon emissions (Figure 17), as a result of demand reductions and changes in the supply mix. Compared with the Baseline, electricity sales are projected to be 4.7 percent lower and carbon emissions from electricity generation 9.3 percent lower in 2000. On a primary fuel basis, by far the largest carbon emissions reductions are the result of reduced coal use for electricity generation.

\section{Annual Results}

In the Combined Policy Case, the growth rate for energy consumption begins to slow after 1997, as actions in the Plan begin to have their greatest impact on private investment that improves energy efficiency. Between 1995 and 1997, primary energy consumption grows by 0.5 percent annually. Between 1997 and 2000, the annual rate of growth of primary energy consumption slows to 0.3 percent.

Although energy consumption continues to increase after 1997, carbon emissions decrease as less carbonintensive fuels begin to play a larger role in the energy mix (Table 37). This change is due to the supply actions in the Plan, which have very little effect on energy consumption, but reduce carbon emissions by promoting greater use of natural gas and renewable fuels in electricity generation. The Plan is projected to reduce carbon emissions from the Administration Baseline by about $10 \mathrm{MMT}$ in 1995 and $66 \mathrm{MMT}$ in 2000. Carbon emissions are projected to increase before 1997, but emissions reductions are realized after 1997, as program funding increases and results begin to be fully realized. 
Figure 16. Change In Annual Carbon Emlsslons by Sector, 1990-2000

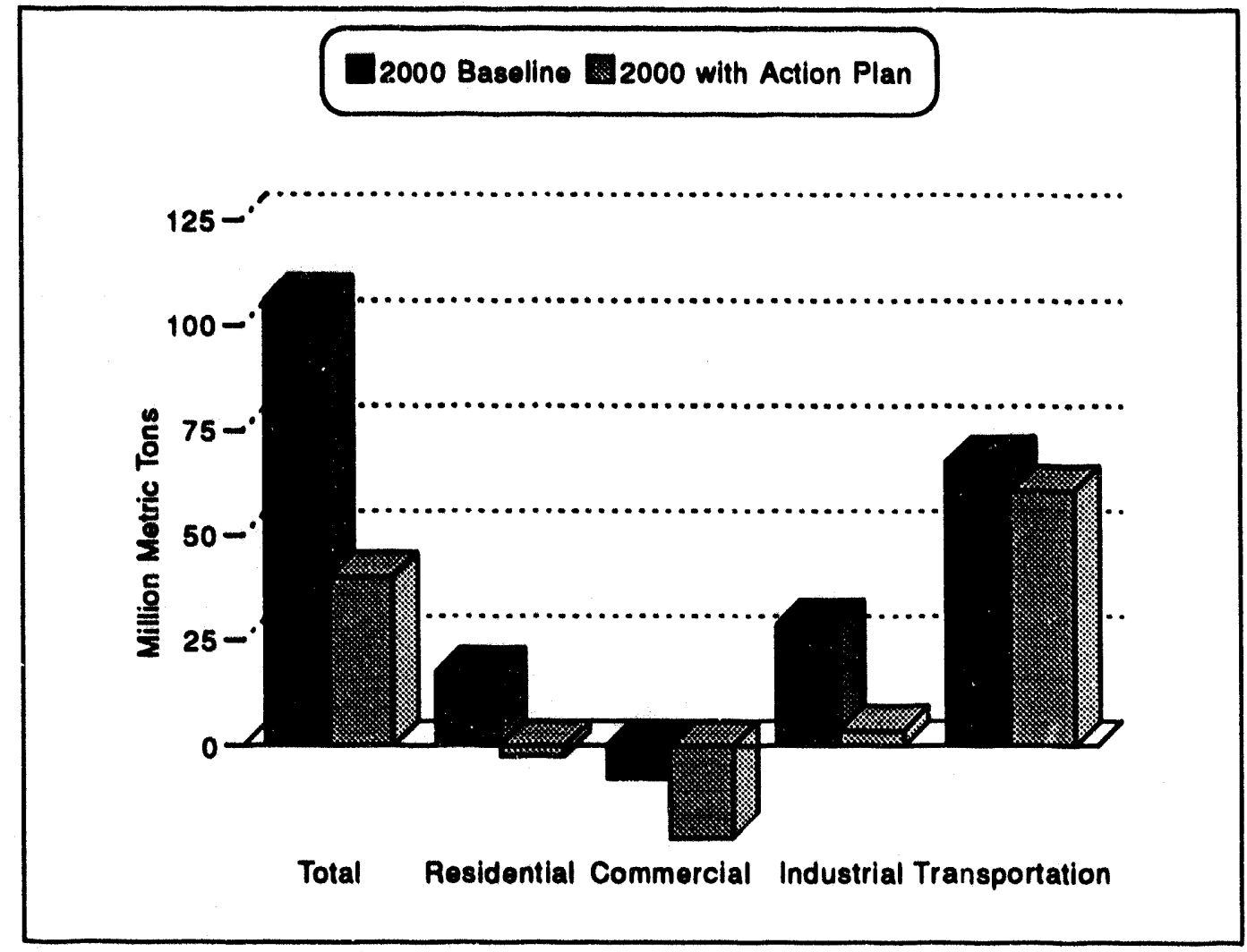

Figure 17. Change In Annual Carbon Emissions by Fuel, 1990-2000

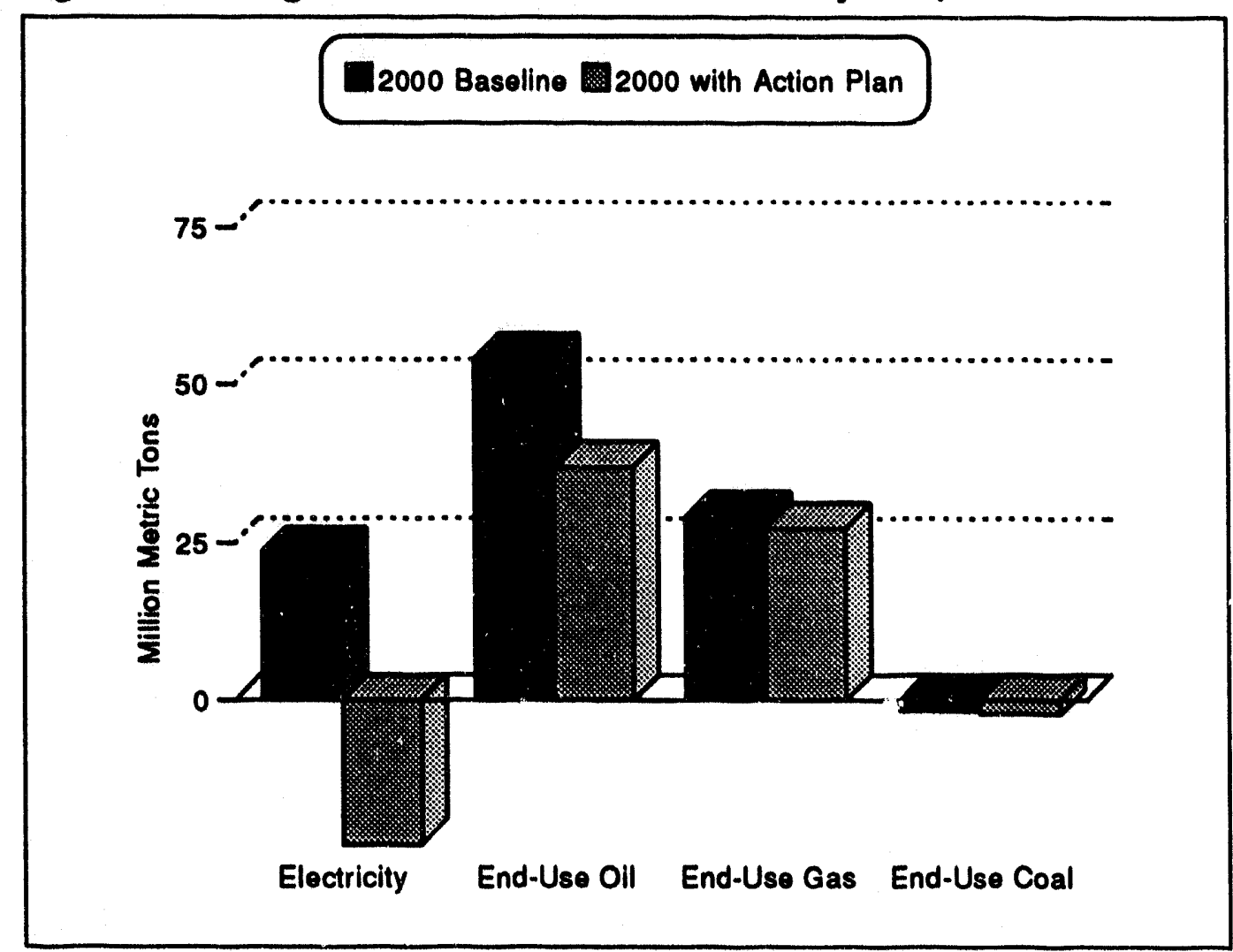


The Climate Change Action Plan: Technical Supplement

Table 37. Primary Energy Consumptlon and Carbon Emlssions in the Combined Polloy Case, $1990-2000$

\begin{tabular}{|c|c|c|}
\hline Year & $\begin{array}{c}\text { Primary Enorgy Consumption } \\
\text { (quadrillion Btu) }\end{array}$ & $\begin{array}{c}\text { Carbon Emiasions } \\
\text { (million motric tons) }\end{array}$ \\
\hline 1990 & 84.8 & $1,338.0$ \\
\hline 1995 & 89.0 & $1,367.9$ \\
\hline 1996 & 89.7 & $1,375.9$ \\
\hline 1997 & 90.5 & $1,383.3$ \\
\hline 1998 & 90.9 & $1,383.7$ \\
\hline 1999 & 91.2 & $1,380.4$ \\
\hline 2000 & 91.4 & $1,378.8$ \\
\hline
\end{tabular}

The time profile of carbon emissions in the Plan reflects two effects. The first is the level of investment in energy conservation equipment and less carbon-intensive supply technologies. The second is the cumulative effect of these changes on equipment stocks. As the energy efficiency of the stock of end-use equipment improves and the stock (existing capacity) of energy production and conversion facilities becomes less carbon-intensive, carbon savings will be realized at a greater rate. Annual energy conservation investments are projected to increase from about $\$ 5$ billion in 1995 to more than $\$ 13$ billion in $\mathbf{2 0 0 0}$ (Figure 18).

Figure 18. Total Inves Comblned Pollcy Cas the Energy Sector Due to Plan Actions, 3000

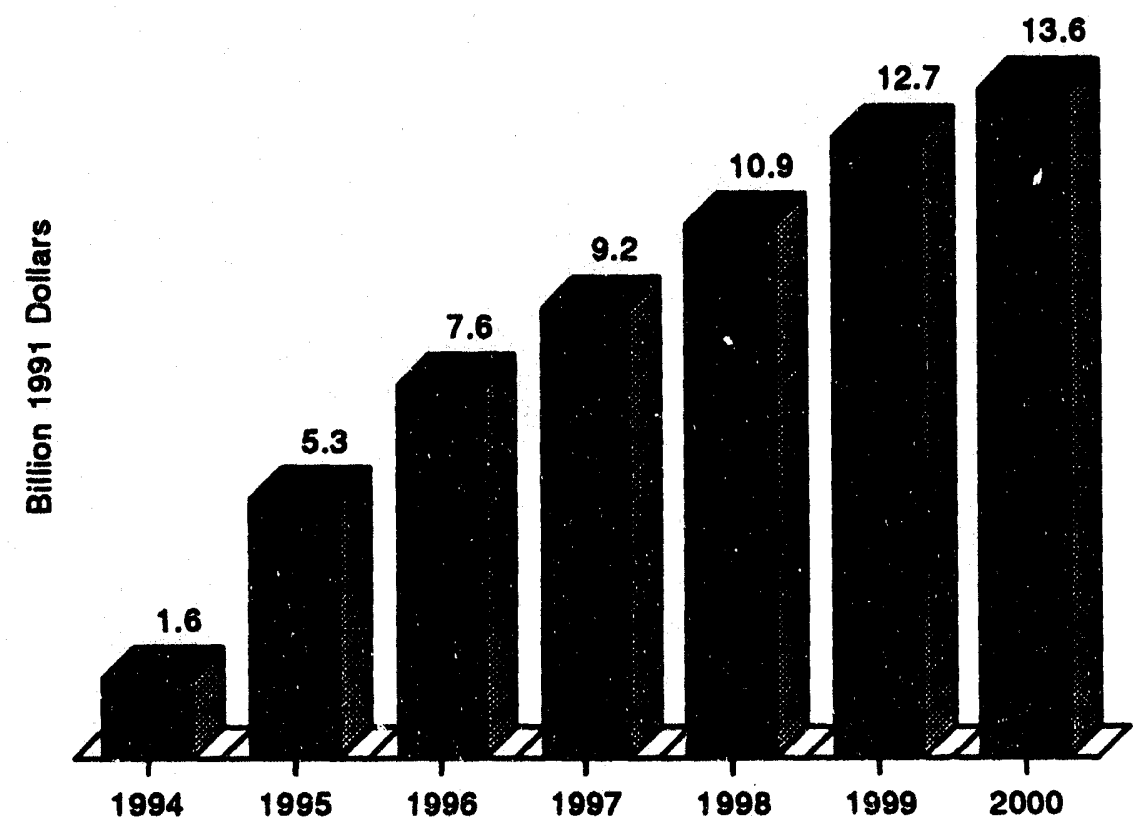


The projections of annual carbon emissions reductions for the Plan are based on information from both the IDEAS model simulations and offline analyses. The offline analyses included detailed annual estimates based on projected program funding, implementation, and results for each action, or closely related groups of actions, in the Plan. The model estimate for 2000 was used to adjust the annual offline estimate for the offsetting and aynergistic effects captured in the model, by multiplying the annual offline estimate by the ratio of the offline estimate for 2000 relative to the model estimate for 2000 . Estimates of carbon savings were based on the change in carbon content of the fuel mix.

The offline analyses also considered that the penetration of new technologies in the marketplace would follow an "S-shaped" pattern. The pattern can be separated into the three parts, coinciding with the expected results of actions in the Plan. In the first part, while the programs begin to be funded, little impact on the energy market is expected. In the second part, with the programs gathering momentum, the market is affected at an increasing rate. In the third part, the programs reach maturity, and their marginal effects begin to diminish-i.e., most of the applications of the new technologies are saturated.

Another factor considered in the offline analyses was the time required for research and development (R\&D) programs to produce actual energy savings. Based on Department of Energy (DOE) experience with the R\&D programs of the Energy Policy Act of 1992 (EPACT), it was assumed that there would be no effects from R\&D until after 1997. Energy and carbon savings resulting from R\&D actione under the Plan were assumed to occur roughly linearly between 1998 and 2000.

\section{Integration of Demand-Side Actions}

To the maximum extent possible, the direct interactions of indiviaual actions were taken into consideration in the development of independent assessments of the impacts of the Plan. For example, energy savings resulting from training and demonstration programs to improve energy efficiency in commercial buildings [actions (4) and (5)] were estimated together offline and then modeled together within the integrated IDEAS framework. As a result, only one carbon estimate was developed for the combined program. In a few cases, the interaction between actions was computed within the IDEAS model. For example, the interaction effects in the industrial sector between recycling [action (16)] and the Motor Challenge [action (12)] were compared using IDEAS. Reduced production of paper products slightly lowers the demand for motor drive services and, therefore, the potential savings from improved motor drive technology. On balance, however, most of the interactive effects were included in the independent assessments of the individual or combined actions. Therefore, the sum of the carbon savings estimated by the independent assessments is virtually the same as the combined savings estimated by IDEAS within each sector. For example, the independent assessment of the carbon savings from demandside actions in the Plan totals 53.9 MMT, and the sum of the combined sectoral totals from IDEAS is 54.0 MMT.

The IDEAS model also accounts for interactions across sectors of the economy. Because of interactions across sectors, the projected carbon reduction from the combined demand-reduction actions in 2000 is 55.2 MMT, which is slightly higher than the 54.0 MMT obtained from summing the IDEAS sectoral totals. The feedback of energy prices and changes in electricity dispatch accounts for this synergistic effect. The impact of an individual action is not sufficiently large to affect the energy supply and demand balance and energy prices. In combination, however, the total impact of demand-side actions produces a measurable increase in electricity prices, because utilities are regulated on a cost-of-service basis. With lower sales, the fixed costs are spread over a smaller level of kilowatthour sales. With all of the actions in place, reduced electricity demand increases electricity prices in 2000 by 2.5 percent. Thus, the combined effect of the individual actions is greater than the sum of their separate effects.

In addition, larger decreases in electricity consumption lead to greater decreases in coal-based electricity generation. As the electricity reductions become significant, much of the oil and gas that can be backed out already has been backed out, and coal use drops disproportionately. 


\section{Integration of Supply-Side Actions}

The Plan includes two kinds of supply-side actions: actions to shift energy use to less carbon-intensive fuels and actions to improve energy efficiency. In the first case, some of the actions aim at reducing the carbon intensity of new generation sources, while others act to shift the use of fuels in existing stock. In the second case, efficiency improvement actions include encouraging the use of high-efficiency transformers and promoting integrated resource planning. Some of these actions "compete" with each other. For example, high-efficiency gas technologies compete with renewable technologies for market share. By 2000, the Administration Baseline projects little new capacity construction, so the overlap is relatively small. In later years, the overlap would be larger. When all supply actions are combined, the net carbon savings are projected to be 10.8 MMT in 2000, compared with 11.4 MMT when the individual measures are summed.

\section{Integration of Demand-Side and Supply-Side Actions}

There are many interactive effects between demand-side and supply-side actions. Some create positive synergies, where the combined impact is greater than the sum, and others are offsetting, where the impact of a combined set of actions is less than the sum of the individual actions. By chance, the two types of interactions are balanced in the Combined Policy Case, so that the total reduction in carbon emissions resulting from all actions combined is projected to be equal to the sum of the projected carbon reductions from the individual demand-side and supply-side actions. For projections beyond 2000, the balance between the symergistic and offsetting interactions would probably not hold. 


\section{Appendix A. Summary Table from the Climate Change Action Plan}

\section{Description of Table Contents}

Table A1 summarizes the environmental and financial impacts of the actions contained in the Climate Change Action Plan (the Plan). ${ }^{32}$ The table columns contain the following information:

Column 1: Action-Reference number used for actions throughout the Plan.

Column 2: Description-Name and description of the action.

Column 3: Federal Obligation, FY1994-2000 (million dollars)_Federal budget outlays as originally requested for fiscal years 1994 through 2000 necessary to implement the action. Note that the dollar values listed in this coium. are in nominal dollars, and are not adjusted for inflation. (All other financial columns present values in undiscounted 1991 dollars.)

Column 4: Private Capital Investment, 1994-2000-Investment by the private sector associated with each action for calendar years 1994 through 2000 (in undiscounted 1991 dollars).

Column 5: Cumulative Value of Energy Savings, 1994-2000-Either (a) the value of energy saved or (b) the change in fuel costs resulting from additional usage of low- or no-carbon fuels (in undiscounted 1991 dollars). Explanatory notes for individual actions are provided as necessary. (a) For actions that save energy, column 5 shows the cumulative dollar value of the energy saved during calendar years 1994 through 2000 as a result of investments made during those years. (b) For actions that cause additional use of low- or no-carbon fuels, column 5 shows the cumulative fuel cost differential for calendar years 1994 through 2000 as a result of using the low- or no-carbon fuel (as compared with the reference fuel).

Column 6: Cumulative Value of Energy Savings, 2001-2010-Same as column 5, for calendar years 2001 through 2010. Note that only those energy savings resulting from investments made during the years 1994 through 2000 are reported. Some of the actions will spur additional investments during the period 2001 to 2010; the energy savings from these additional investments are not reflected in this column.

Column 7: GHG Reductions in 2000 (MMTce)-Amount by which the action would lower greenhouse gas (GHG) emissions, as compared with the Administration Baseline, in 2000. Reductions are measured in million metric tons carbon equivalent (MMTce). The Global Warming Potential (GWP) index was used to compute carbon equivalents for other greenhouse gases.

Column 8: Post-2000 Emission Reduction Potential-Qualitative information on the long-term emission reduction potential of the action. The number of asterisks reflects the ratio of expected post-2000 GHG reductions to the GHG reductions projected for the year 2000 (column 7). The higher the ratio, the greater the number of asterisks shown.

32. The table that follows includes minor corrections from the table originally published in The Climate Change Action Plan. 
Table A1. Summary Table of Actions

\begin{tabular}{|c|c|c|c|c|c|c|c|}
\hline \multirow[b]{2}{*}{ Action } & \multirow[b]{2}{*}{ Description } & $\begin{array}{l}\text { Foderal } \\
\text { Obllgation, } \\
\text { Fy19e4-200, }\end{array}$ & $\begin{array}{c}\text { Private } \\
\text { Caplial } \\
\text { inveatmont, } \\
19042000 \\
\end{array}$ & $\begin{array}{c}\text { Cumulathe } \\
\text { Valus of } \\
\text { Energy Savinge, } \\
1904-2000\end{array}$ & $\begin{array}{c}\text { Cumulative } \\
\text { Value of } \\
\text { Enorgy Sovings, } \\
2001-2010\end{array}$ & \multirow{2}{*}{$\begin{array}{c}\text { CHG } \\
\text { Roductions } \\
\text { in } 2000 \\
\text { (inTo) }\end{array}$} & \multirow{2}{*}{$\begin{array}{l}\text { Post-2000 } \\
\text { Emiscion } \\
\text { Reduction } \\
\text { Potential }\end{array}$} \\
\hline & & (million dollare) & \multicolumn{3}{|c|}{ (milltion undiscounted 1991 dollere) } & & \\
\hline \multicolumn{7}{|c|}{ Commercial Energy Efficiency Actions } & - \\
\hline \multicolumn{8}{|c|}{ Partnership Programs } \\
\hline (1) & $\begin{array}{l}\text { Coordinate DOE Rebuild America and EPA Energy } \\
\text { Star Buildings }\end{array}$ & $\$ 190$ & $\$ 6,300$ & $\$ 2,800$ & $\$ 11,900$ & 3.1 & \multirow[t]{2}{*}{ • } \\
\hline (2) & Expand EPA's Green Lights Program & $\$ 98$ & $\$ 3,300$ & $\$ 1,900$ & $\$ 8,100$ & 2.5 & \\
\hline \multicolumn{8}{|c|}{ Dovelopment, Commerciallzation, and Training } \\
\hline (3) & Establish State Revolving Fund for Public Buildings & $\$ 55$ & $\$ 2,500$ & $\$ 1,000$ & $\$ 4,400$ & 1.1 & 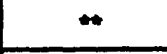 \\
\hline (4) & $\begin{array}{l}\text { Expand Cost-Shared Demonstration of Emerging } \\
\text { Technologies }\end{array}$ & $\$ 60$ & \multirow{2}{*}{$\$ 8,400$} & \multirow{2}{*}{$\$ 2,900$} & \multirow{2}{*}{$\$ 12,300$} & \multirow{2}{*}{3.8} & \multirow{2}{*}{ - } \\
\hline (5) & $\begin{array}{l}\text { Establish Enorgy Efficioncy and Renowablo Energy } \\
\text { Information and Training Programs }\end{array}$ & $\$ 42$ & & & & & \\
\hline \multicolumn{2}{|r|}{ Commerchal Enorgy Eniciency Combined Results } & $\$ 405$ & $\$ 20,500$ & $\$ 8,600$ & $\$ 36,700$ & 10.6 & \\
\hline
\end{tabular}

\begin{tabular}{|c|c|c|c|c|c|c|c|}
\hline \multicolumn{8}{|c|}{ Residential Energy Efficiency Actions } \\
\hline \multicolumn{8}{|c|}{ Applience Improwments } \\
\hline (6) & Form Golden Carrot Market-Pull Partnerships & $\$ 193$ & \multirow{2}{*}{$\$ 19,500$} & \multirow{2}{*}{$\$ 9,400$} & \multirow{2}{*}{$\$ 40,700$} & \multirow{2}{*}{11.8} & \multirow{2}{*}{$*$} \\
\hline (7) & Enhance Residential Appliance Standards & so & & & & & \\
\hline \multicolumn{8}{|c|}{ Home improvements } \\
\hline (8) & $\begin{array}{l}\text { Promote Home Energy Rating Systems and Energy- } \\
\text { Efficient Mortgages }\end{array}$ & $\$ 12$ & \multirow{4}{*}{$\$ 11,700$} & \multirow{4}{*}{$\$ 5,400$} & \multirow{4}{*}{$\$ 21,600$} & \multirow{4}{*}{4.4} & \multirow{4}{*}{ - } \\
\hline (9) & $\begin{array}{l}\text { Expand Cool Communities Program in Citios and } \\
\text { Federal Faciltios }\end{array}$ & $\$ 12$ & & & & & \\
\hline (10) & Upgrade Residential Building Standards & $\$ 87$ & & & & & \\
\hline (11) & $\begin{array}{l}\text { Create Energy Efficioncy Programs and Housing } \\
\text { Technology Conters }\end{array}$ & $\$ 93$ & & & & & \\
\hline \multicolumn{2}{|r|}{ Rosidential Energy Efficiency Combined Roceults } & $\$ 097$ & $\$ 31,200$ & $\$ 14,800$ & $\$ 62,300$ & 16.3 & \\
\hline
\end{tabular}

See notes at ond of table. 
Table A1. Summary Table of Actions (Continued)

\begin{tabular}{|c|c|c|c|c|c|c|c|}
\hline \multirow[b]{2}{*}{ Action } & \multirow[b]{2}{*}{ Description } & \multirow{2}{*}{$\begin{array}{c}\text { Federal } \\
\text { Obligation, } \\
\text { FY1994-2000 } \\
\text { (million dollars) }\end{array}$} & 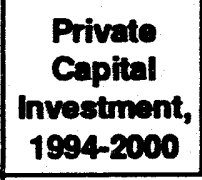 & $\begin{array}{c}\text { Cumulative } \\
\text { Value of } \\
\text { Energy Savings, } \\
1994-2000\end{array}$ & $\begin{array}{c}\text { Cumulative } \\
\text { Valus of } \\
\text { Energy Savings, } \\
2001-2010 \\
\end{array}$ & \multirow{2}{*}{$\begin{array}{c}\text { GHG } \\
\text { Reductions } \\
\text { in } 2000 \\
\text { (MinTce) }\end{array}$} & \multirow{2}{*}{$\begin{array}{l}\text { Post-2000 } \\
\text { Emiasion } \\
\text { Roduction } \\
\text { Potential } \\
\end{array}$} \\
\hline & & & \multicolumn{3}{|c|}{ (million undiscounted 1991 dollars) } & & \\
\hline \multicolumn{8}{|c|}{ Methane Reduction and Recovery Actions } \\
\hline (32) & Expand "Natural Gas Star" & $\$ 6$ & $\$ 60$ & $\$ 100$ & $\$ 110$ & 3.0 & * \\
\hline (33) & Increase Stringency of Landfill Rules & $\$ 0$ & $\mathrm{n} / \mathbf{a}$ & $\mathrm{n} / \mathrm{a}$ & $n / a$ & 4.2 & $*$ \\
\hline (34) & Expand Landfill Outreach Program & $\$ 6$ & $\$ 180$ & $\$ 140$ & $\$ 270$ & 1.1 & $*$ \\
\hline (35) & Launch Coalbed Methane Outreach Program & $\$ 8$ & $\$ 80$ & $\$ 90$ & $\$ 160$ & 2.2 & 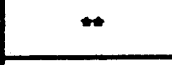 \\
\hline (36) & $\begin{array}{l}\text { Expand RD\&D for Methane Recovery from Coal } \\
\text { Mining }\end{array}$ & $\$ 17$ & $\$ 200$ & $\$ 120$ & $\$ 810$ & 1.5 & $\cdots$ \\
\hline (37) & Expand RD\&D for Methane Recovery from Landfills & $\$ 9$ & $\$ 200$ & $\$ 80$ & $\$ 420$ & 1.0 & $\cdots$ \\
\hline (38) & $\begin{array}{l}\text { Expand AgStar Partnership Program with Livestock } \\
\text { Producers }\end{array}$ & $\$ 19$ & $\$ 140$ & $\$ 120$ & $\$ 180$ & 1.5 & * \\
\hline (39) & $\begin{array}{l}\text { Improve Ruminant Productivity and Product } \\
\text { Marketing }\end{array}$ & $\$ 28$ & $\mathbf{n} / \mathbf{a}$ & $\mathbf{n} / \mathbf{a}$ & $n / a$ & 1.8 & * \\
\hline \multicolumn{2}{|r|}{ Methane Reduction and Recovery Combined Results } & $\$ 93$ & $\$ 860$ & $\$ 650$ & $\$ 1,950$ & 16.3 & \\
\hline
\end{tabular}

\begin{tabular}{|c|c|c|c|c|c|c|c|}
\hline \multicolumn{8}{|c|}{ HFC, PFC, and Nitrous Oxide Reduction Actions } \\
\hline (40) & $\begin{array}{l}\text { Narrow Use of Chemicals with High Global Warming } \\
\text { Potential, Using the Clean Air Act and Production } \\
\text { Stewardship to Reduce Emissions }\end{array}$ & $\$ 9$ & $\mathbf{n} / \mathbf{a}$ & $\mathbf{n} / \mathbf{a}$ & n/a & 5.0 & * \\
\hline (41) & $\begin{array}{l}\text { Create Partnership with Manufacturers of HFC-22 to } \\
\text { Eliminate HCFC-23 Emissions }\end{array}$ & $\$ 13$ & $n / a$ & $n$ & $n / \mathbf{a}$ & 5.0 & $\cdots$ \\
\hline (42) & $\begin{array}{l}\text { Launch Partnership with Aluminum Producers to } \\
\text { Reduce Emissions from Manufacturing Processes }\end{array}$ & $\$ 3$ & nia & $n / a$ & $n / a$ & 1.8 & * \\
\hline (17) & Improve Efficiency of Fertilizer Nitrogen Use & \multicolumn{4}{|c|}{ See Action (17) } & 4.5 & $\bullet$ \\
\hline \multicolumn{2}{|r|}{ HFC, PFC, and Nitrous Oxide Combined Results } & $\$ 26$ & $\mathbf{n} / \mathbf{a}$ & $\mathbf{n a}$ & $\mathbf{n} / \mathbf{a}$ & 16.3 & \\
\hline
\end{tabular}




\begin{tabular}{|c|c|c|c|c|c|c|c|}
\hline & \multirow[b]{2}{*}{ Description } & \multirow{2}{*}{ 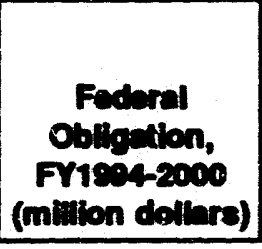 } & $\begin{array}{c}\text { Prives } \\
\text { Caplial } \\
\text { investiment, } \\
1904-2000\end{array}$ & $\begin{array}{c}\text { Connulatho } \\
\text { Volus of } \\
\text { Encroy Savings, } \\
1904-2000\end{array}$ & $\begin{array}{c}\text { Cumbiutin } \\
\text { Value of } \\
\text { Enengy Savinge, } \\
2001-2010 \\
\end{array}$ & \multirow{2}{*}{$\begin{array}{c}\text { Cria } \\
\text { Raductions } \\
\text { in } 2000 \\
\text { (n)Tos) }\end{array}$} & \multirow{2}{*}{$\begin{array}{l}\text { Post-2000 } \\
\text { Emiacion } \\
\text { Raduction } \\
\text { Potential }\end{array}$} \\
\hline Action & & & \multicolumn{3}{|c|}{ (miltion undiscounted 1991 dollare) } & & \\
\hline \multicolumn{8}{|c|}{ Forostry Aotions } \\
\hline (43) & $\begin{array}{l}\text { Reduce the Depletion of Nonindustrial Private } \\
\text { Forests }\end{array}$ & 84 & So & na & na & 4.0 & \\
\hline (44) & $\begin{array}{l}\text { Accolerde Tree Planting in Nonindustrial Private } \\
\text { Forests }\end{array}$ & $\$ 71$ & $\$ 40$ & $\mathrm{na}$ & n/a & 0.5 & $\ldots$ \\
\hline (16) & $\begin{array}{l}\text { Accolerato Source Reduction, Pollution Provention, } \\
\text { and Recycling }\end{array}$ & \multicolumn{4}{|c|}{ See Action (16) } & 5.0 & • \\
\hline (9) & $\begin{array}{l}\text { Expand Cool Communitios Program in Cities and } \\
\text { Federal Faciltive }\end{array}$ & \multicolumn{4}{|c|}{ Seo Action (9) } & 0.5 & • \\
\hline & Foreaty Combined Reoults & $\$ 75$ & 290 & $\mathbf{n}$ & no & 10.0 & \\
\hline & Total for Encroy Sectors & $-\infty e 87$ & $\$ 00,685$ & 800,570 & $\$ 205,000$ & 66.0 & \\
\hline & Total for Non-Energy Soctors & S194 & $\operatorname{sen}$ & $\operatorname{ses} 0$ & $\$ 1,950$ & 426 & \\
\hline & GRAND TOTAL & $-\$ 793$ & $\$ 91,535$ & $\$ 61,220$ & $\$ 206,890$ & 108.6 & \\
\hline
\end{tabular}

Notes: Combined CHG redections may not equal the sum of individual actions dus to synorgietic effects.

For post-2000 emicsion reduction potential, one acterisk (") indicates static or moderately increasing post-2000 reductions rolative to the projected emissions reductions in the yuar 2000; two asterisks ("*) indicate a 50-percent or greater increase in projected annual emissions reductions over the 2000 lovel; and three asteriaks ("rol) indicate an increase of more than 200 percent in projected annual emissions reductions over the 2000 lovel.

Sources: Greenhouse gas emicsions eetimetes for 1990 are taken from Enorgy Information Administration, Emissions of Greenhouse Gases in the Unitod Stafos 19851990, DOE/ELA-0573 (Washington, DC, Oct. 1993), and U.S. Environmental Protection Agoncy, Anthropoggonic Mothane Emissions in the Unitod Statos: Estimatos for 1990 Washington, DC, Apr. 1993). Extimates of nitrous oxide emissions from agriculture were provided by the U.S. Department of Agriculkure. Interpolations and projections are beeed on analyees conducted by DOE, EPA, and USDA for the Climate Change Action Plan. Baseline estimates of emissions may change as internationally recognized greonhouse gas accountiny methodologies ovolvo. 
Table A1. Summary Table of Actions (Continued)

\begin{tabular}{|c|c|c|c|c|c|c|c|}
\hline \multirow[b]{2}{*}{ Action } & \multirow[b]{2}{*}{ Doscription } & \multirow{2}{*}{$\begin{array}{c}\text { Fodieral } \\
\text { Obligction, } \\
\text { FYieoteoco } \\
\text { (militen dollars) }\end{array}$} & $\begin{array}{c}\text { Prwute } \\
\text { Capilal } \\
\text { investmont, } \\
18942000 \\
\end{array}$ & $\begin{array}{c}\text { Connulatios } \\
\text { Value of } \\
\text { Encroy Savings, } \\
18042000 \\
\end{array}$ & $\begin{array}{c}\text { Comulative } \\
\text { Value of } \\
\text { Energy Savinge, } \\
2001-2010 \\
\end{array}$ & \multirow{2}{*}{ 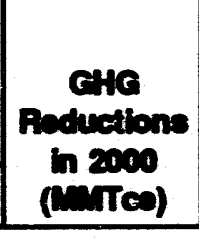 } & \multirow{2}{*}{$\begin{array}{l}\text { Poot-2ace } \\
\text { Emiosion } \\
\text { Roduction } \\
\text { Potential } \\
\end{array}$} \\
\hline & & & \multicolumn{3}{|c|}{ (milion undiscounted 1991 dollers) } & & \\
\hline \multicolumn{8}{|c|}{ Industrial Energy Efifielency Actions } \\
\hline \multicolumn{8}{|c|}{ Accolorated Efficiency } \\
\hline (12) & Create a Motor Challenge Program & $\$ 30$ & $\$ 4,000$ & $\$ 5,300$ & $\$ 17,000$ & 8.8 & $\therefore$ \\
\hline (13) & $\begin{array}{l}\text { Establish Industrial Gciden Carrot Program for } \\
\text { Industrial Air Compressors, Pumps, Fans, and } \\
\text { Drives }\end{array}$ & $\$ 14$ & \multirow{2}{*}{$\$ 600$} & \multirow{2}{*}{$\$ 1,300$} & \multirow{2}{*}{$\$ 7,800$} & \multirow{2}{*}{2.9} & \\
\hline (14) & $\begin{array}{l}\text { Accelerate the Adoption of Energy-Efficient Process } \\
\text { Technologies, Including the Creation of "One-Stop } \\
\text { Shops" }\end{array}$ & $\$ 71$ & & & & & \\
\hline (15) & $\begin{array}{l}\text { Expand and Enhance Energy Analysis and } \\
\text { Diagnostic Centers }\end{array}$ & $\$ 27$ & $\$ 160$ & $\$ 280$ & $\$ 960$ & 0.5 & $\cdots$ \\
\hline \multicolumn{8}{|c|}{ Pollution Provention } \\
\hline (16) & $\begin{array}{l}\text { Accelerate Source Reduction, Pollution Prevention, } \\
\text { and Recycling }\end{array}$ & $\$ 86$ & $\$ 90$ & $\$ 5,400$ & $\$ \$ 1,100$ & 4.2 & 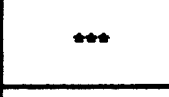 \\
\hline (17) & Improve Efficiency of Fertilizer Nitrogen Use & $\$ 19$ & \multirow{2}{*}{$\mathbf{n} / \mathbf{a}$} & \multirow{2}{*}{$\$ 1,900$} & \multirow{2}{*}{$\$ 9,000$} & \multirow{2}{*}{2.7} & \multirow{2}{*}{ * } \\
\hline (18) & Reduce Pesticide Use & $\$ 0$ & & & & & \\
\hline \multicolumn{2}{|r|}{ Industrial Enorgy Efficiency Combined Reaults } & $\$ 247$ & $\$ 4,850$ & $\$ 14,180$ & $\$ 68,960$ & 19.0 & \\
\hline
\end{tabular}

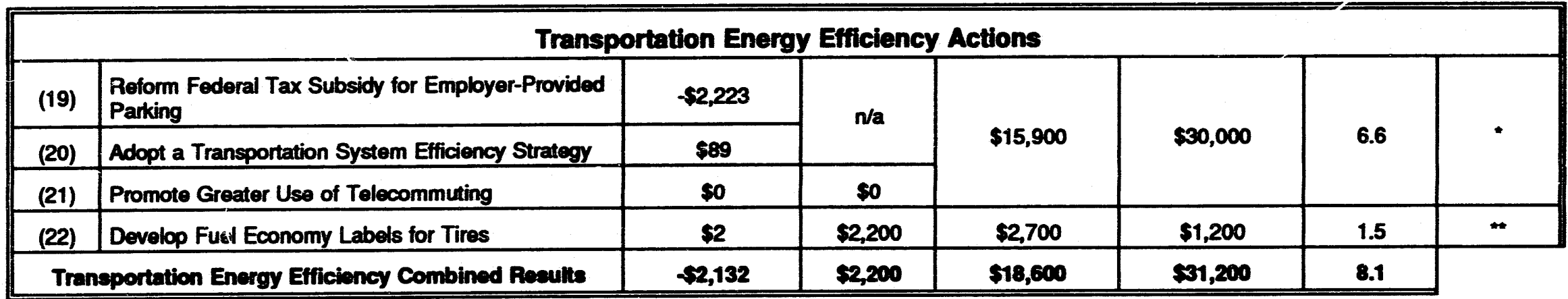




\begin{tabular}{|c|c|c|c|c|c|c|c|}
\hline \multirow[b]{2}{*}{ Action } & \multirow[b]{2}{*}{ Description } & \multirow{2}{*}{$\begin{array}{c}\text { Federal } \\
\text { Obligation, } \\
\text { FY1se-2000 } \\
\text { (million dollars) }\end{array}$} & $\begin{array}{c}\text { Private } \\
\text { Capilal } \\
\text { invectument, } \\
1804-2000\end{array}$ & $\begin{array}{c}\text { Cumulative } \\
\text { Value of } \\
\text { Energy Savings, } \\
1994-2000\end{array}$ & $\begin{array}{c}\text { Cumulative } \\
\text { Value of } \\
\text { Enorgy Savings, } \\
2001-2010 \\
\end{array}$ & \multirow{2}{*}{$\begin{array}{c}\text { CHG } \\
\text { Reductions } \\
\text { in } 2000 \\
\text { (MnTाल) } \\
\end{array}$} & \multirow{2}{*}{$\begin{array}{l}\text { Poet-2000 } \\
\text { Emiasion } \\
\text { Poduction } \\
\text { Potentia! }\end{array}$} \\
\hline & & & \multicolumn{3}{|c|}{ (million undiscounted 1991 dollars) } & & \\
\hline \multicolumn{8}{|c|}{ Energy Supply Actions } \\
\hline \multicolumn{8}{|c|}{ Enhenced Naturnl Gas Utilization } \\
\hline (23) & $\begin{array}{l}\text { Increase Natural Gas Share of Energy Use through } \\
\text { Federal Regulatory Reform }\end{array}$ & $\$ 0$ & so & $\$ 1,900$ & $-\$ 260$ & 2.2 & \\
\hline (24) & $\begin{array}{l}\text { Promote Seasonal Gas Use for the Control of } \\
\text { Nitrogen Oxides }\left(\mathrm{NO}_{\mathrm{x}}\right)\end{array}$ & so & $-\$ 930$ & $\$ 460$ & $-\$ 940$ & 2.8 & - \\
\hline (25) & Commorcialize High-Efficiency Gas Technologies & $\$ 62$ & $\$ 140$ & $\$ 70$ & $\$ 630$ & 0.6 & $\cdots$ \\
\hline \multicolumn{8}{|c|}{ Enhanced Renowable Commercialization } \\
\hline (26) & $\begin{array}{l}\text { Form Renewable Energy Market Mobilization } \\
\text { Collaborative with Technology Demonstrations }\end{array}$ & $\$ 432$ & $\$ 700$ & $\$ 280$ & $\$ 1,100$ & 0.8 & 必 \\
\hline (27) & Promote Integrated Resource Planning & $\$ 39$ & n/a & $\$ 1,500$ & $\$ 4,300$ & 1.4 & \\
\hline \multicolumn{8}{|c|}{$\begin{array}{l}\text { Improve Performance of Existing Zoro Emiseions } \\
\text { Tuchnology }\end{array}$} \\
\hline (28) & $\begin{array}{l}\text { Retain and Improve Hydroelectric Generation at } \\
\text { Existing Dams }\end{array}$ & $\begin{array}{l}\text { Leasing } \\
-\$ 480\end{array}$ & $\$ 1,500$ & $\$ 550$ & $\$ 2,500$ & 2.0 & \\
\hline \multicolumn{8}{|c|}{ Inproved Energy Efficiency } \\
\hline (29) & $\begin{array}{l}\text { Accelerate the Development of Efficiency Standards } \\
\text { for Electric Transformers }\end{array}$ & \$o & \multirow[t]{2}{*}{$\$ 480$} & \multirow[t]{2}{*}{$\$ 280$} & \multirow[t]{2}{*}{$\$ 600$} & \multirow[t]{2}{*}{0.8} & \multirow[t]{2}{*}{ * } \\
\hline (30) & Launch Energy Star Transformers & $\$ 4$ & & & & & \\
\hline (31) & $\begin{array}{l}\text { Reduce Electric Generation Losses Through } \\
\text { Transmission Pricing Reform }\end{array}$ & \$o & $\$ 5$ & $\$ 270$ & $\$ 1,040$ & 0.8 & \\
\hline & Energy Supply Combined Results & $\$ 57$ & $\$ 1,885$ & $\$ 4,390$ & $\$ 8,970$ & 10.8 & \\
\hline
\end{tabular}

See notes at end of table. 


\section{Notes on Individual Actlons}

Action (18): The private investment is listed as " $\mathrm{n} / \mathrm{a}$ " because there are no private capital investments anticipated in this action.

Actions (19), (20), and (21): The private investment is listed as " $n / a$ " because these three actions will result in behavioral changes that affect private investment in ways that cannot be estimated.

Action (23): This action yields energy savings in the near term (through 2000) because it displaces higher cost end-use fuels. However, energy costs are expected to be higher than the Administration Baseline (without the action) in the longer term, reflecting the price premium of natural gas relative to coal and the longer run impact of higher gas use on gas prices.

Action (24): This action does not save money on energy costs, but rather is expected to increase utility energy expenditures, reflecting the price premium of natural gas relative to coal and the longer run impact of higher gas use on gas prices.

Action (27): This action is expected to reduce private investment requirements because utilities will substitute investment in end-use equipment for investment in more capital-intensive generating equipment. However, " $\mathrm{n} / \mathrm{a}$ " is listed because detailed estimates could not be derived.

Action (81): This action reduces private capital investment requirements because it decreases the need for transmission capacity.

Action (39): Private investments will likely be made by medium to large landfills, as the final rule is expected to include an exemption for smaller landfills. Cost estimates and value of energy for these actions will be availables at final promulgation of the rule.

Actions (34) and (87): The numbers listed in the energy savings columns for these two actions represent revenues from the sale of energy produced from landfill gas.

Actions (86) and (36): The numbers listed in the energy savings columns for these two actions represent revenues from the sale of natural gas and electricity.

Action (39): Private investment is anticipated to be negligible. No energy market impact is projected, 80 no enersy savings were calculated.

Action (40): The private costs of this program have not yet been estimated, but they are expected to be low, principally because restrictions will occur only in cases where other alternatives are available. No energy market impact is projected, so no energy savings were calculated.

Action (41): Precise estimates of private investment are not yet available, although the Partnership effort will be designed to achieve the highest cost-effective emissions reductions at the lowest cost to manufacturers. No energy market impact is projected, so no energy savings were calculated.

Action (42): No precise estimates of private investment or energ5' savings are available for this action. The net cost of the action is expected to be close to zero, as any investment in new technology will be offset by energy savings from improvements in energy efficiency.

Actions (48) and (44): Energy savings calculations are not relevant, because the forestry actions operate through carbon uptake by trees. 


\section{Appendix B. Annual Greenhouse Gas Emissions Estimates}

Table B1. Annual Greenhouse Gas Emissions Estimates for the Combined Pollcy Case, 1990-2000

\begin{tabular}{|c|c|c|c|c|c|c|c|}
\hline \multirow{2}{*}{ Oreenhouse Cas } & \multicolumn{7}{|c|}{$\begin{array}{l}\text { Eotlimated Emisalons } \\
\text { (million motric tons carbon equivalent) }\end{array}$} \\
\hline & 1980 & 1995 & 1906 & 1997 & 1898 & 1999 & 2000 \\
\hline Enorgy-Rolated Carbon & 1,338 & 1,358 & 1,376 & 1,383 & 1,384 & 1,380 & 1,379 \\
\hline Other Carbon" & 29 & 29 & 29 & 29 & 29 & 29 & 29 \\
\hline Forostry Sinks & -130 & -133 & -136 & -139 & -142 & -145 & -147 \\
\hline Not Carbon & 1,237 & 1,264 & 1,269 & 1,273 & 1,270 & 1,265 & 1,261 \\
\hline Mothane & 166 & 177 & 176 & 175 & 147 & 142 & 134 \\
\hline HFCs and PFCs & 20 & 29 & 31 & 32 & 33 & 34 & 33 \\
\hline Nitrous Oxide & 39 & 39 & 34 & 33 & 33 & 32 & 31 \\
\hline Total & 1,482 & 1,510 & 1,510 & 1,513 & 1,493 & 1,472 & 1,458 \\
\hline
\end{tabular}

"Includes omissions from feedstocks and comont. 


\begin{tabular}{|c|c|c|c|c|}
\hline Aollon & Contaot & Agenoy & Phone & FAX \\
\hline \multirow{2}{*}{ (1) Coordinate DOE Robulld America and EPA Energy Star Buildings } & Traoy Narel & EPA & 202-233-9145 & $202-283-8578$ \\
\hline & John Milthone & DOE & $202.586 \cdot 1510$ & 202-586-5054 \\
\hline (2) Expend EPA's Green Lights Program & Traoy Narol & EPA & 202.233 .9145 & $202-233-9578$ \\
\hline (3) Establish State Rovolving Fund for Public Bulldings & Frank Siowart & DOE & 202.586-9220 & $202.586-9260$ \\
\hline (4) Expand Cost-Shared Demonstration of Emerging Technologios & David Patton & DOE & $202 \cdot 586-8280$ & $202.586-2176$ \\
\hline $\begin{array}{l}\text { (5) Establish Energy Efficiency and Renowable Energy Information and } \\
\text { Training Programs }\end{array}$ & David Patton & DOE & $202-586-8280$ & 202-586-2176 \\
\hline \multirow{2}{*}{ (6) Form Golden Carrot Markot-Pull Partnerships } & John Milthore & DOE & $202 \cdot 586-1510$ & 202-586-6964 \\
\hline & Michaol L'Ecuyer & EPA & $202-233-9127$ & $202-233-9678$ \\
\hline (7) Enhance Rosidential Appliance Standards & Cart Adams & DOE & 202.586 .9142 & $202-586-4617$ \\
\hline \multirow{2}{*}{ (8) Promob Homo Energy Rating Systems and Energy-Efficient Mortgages } & John Nillhono & DOE & 202-586-1510 & 202-586-5954 \\
\hline & Robent Groberg & HUD & $202-708-3295$ & $202-708-3363$ \\
\hline (9) Expand Cool Communitios Program in Cities and Foderal Facilities & Steve Winnetto & EPA & $202-260-6405$ & $202-260-6923$ \\
\hline \multirow{2}{*}{ (10) Upgrade Residential Building Standards } & Robert Groborg & HUD & $202-708-3295$ & $202-708-3563$ \\
\hline & Jean Boulin & DOE & 202-586-9870 & $202-586-4617$ \\
\hline (11) Creato Enorgy Efficlenoy Programs and Housing Tochnology Conters & Jim Broderick & DOE & 202.586 .5253 & $202-586-1628$ \\
\hline (12) Create a Motor Challenge Program & Paul Schoiking & DOE & $202 \cdot 586 \cdot 7234$ & 202.586-7234 \\
\hline $\begin{array}{l}\text { (13) Establish Industrial Golden Carrot Programs for Industrial } \\
\text { Air Comprossors, Pumps, Fans, and Drives }\end{array}$ & Joff Wobb & EPA & 202.233 .9736 & $202-233-9569$ \\
\hline $\begin{array}{l}\text { (14) Accelerate the Adoption of Enorgy-Efficient Process Technologies, } \\
\text { Including the Creation of "One-Stop Shops" }\end{array}$ & Brian Card & DOE & $202.586-9228$ & 202-586-2176 \\
\hline (15) Expand and Enhance Enorgy Analysis and Diagnostic Centers & Joff Dowd & DOE & $202-586-7258$ & $202-586-4447$ \\
\hline \multirow{4}{*}{ (16) Accolerate Source Reduction, Pollution Prevention, and Recycling } & Bill Hohenstein & EPA & $202-260-6803$ & $202-260-6406$ \\
\hline & David Darr & $\begin{array}{c}\text { Forest } \\
\text { Sonvice } \\
\end{array}$ & 202-206-1052 & 202-205-1087 \\
\hline & Card Whitman & USDA & $703-235-9018$ & $703-235-9046$ \\
\hline & Ron MolHugh & DOE & 202-586-7228 & 202-586-5391 \\
\hline \multirow{2}{*}{ (17) Improvo Efficienoy of Fertilizer Nitrogen Use } & Clay Ogg & EPA & 202-260-6351 & $202-260-2300$ \\
\hline & Card Whitman & USDA & 703-235-9018 & 703-235-9046 \\
\hline (18) Reduce Pesticide Use & Cindy Jacobs & EPA & 202-233-9042 & 202-233-8569 \\
\hline (19) Rolorm Foderal Tax Subsidy for Employer-Provided Parking & John Kessler & EPA & $202 \cdot 260-3761$ & $202-280-0512$ \\
\hline (20) Adopt a Traneportation System Efficionoy Strategy & John Kessler & EPA & $202-260-3761$ & $202-260-0612$ \\
\hline \multirow{2}{*}{ (21) Promote Greater Use of Telecommuting } & Lew Fulton & DOE & 202-586-1197 & $202-586-4447$ \\
\hline & Joo Canny & DOT & $202-386-4540$ & $202-366-7127$ \\
\hline (22) Dovelop Fuel Economy Labols for Tires & Low Fulton & DQE & $202-686-1197$ & $202-686.4447$ \\
\hline
\end{tabular}




\begin{tabular}{|c|c|c|c|c|}
\hline Aotion & Contaot & Arenoy & Phone & $\mathbf{F A X}$ \\
\hline $\begin{array}{l}\text { (23) Inorease Naturel Gas Shero of Energy Use through Federal } \\
\text { Regulatory Rolorm }\end{array}$ & Kon Malloy & DOE & $202 \cdot 686 \cdot 2040$ & $202 \cdot 686 \cdot 4341$ \\
\hline (24) Promols Seasond Cas Use for the Control of Nitrogen Oxides (NO) & Eruce Schillo & EPA & $202 \cdot 260 \cdot 1080$ & $202 \cdot 260.0512$ \\
\hline (26) Commercialize High-Efiliency Gas Technologios & Pichard Dye & DOE & 202.686 .6490 & $202-686-1188$ \\
\hline \multirow{2}{*}{$\begin{array}{l}\text { (26) Form Renowable Enemgy Market Mobilization Collaborativo } \\
\text { with Technology Demonsurations }\end{array}$} & Robert Annen & DOE & $202 \cdot 586 \cdot 1720$ & $202 \cdot 886 \cdot 5127$ \\
\hline & Erio Poterson & DOE & 202-686-8360 & $202.586-2176$ \\
\hline (27) Promows Integrated Resource Planning & David Moyer & DOE & 202.586.5735 & 202-586-0328 \\
\hline (28) Retain end Improve Hydroelectrio Conoration at Existing Dams & Paul Camior & DOE & $202-586-6650$ & $202.586-0328$ \\
\hline \multirow{2}{*}{$\begin{array}{l}\text { (29) Accolerate the Dovelopment of Efficiency Standards for } \\
\text { Electric Translormers }\end{array}$} & Robert Brewer & DOE & $202 \cdot 586-2828$ & 202-586-0784 \\
\hline & Linda Latham & EPA & $202-233.8420$ & $202.233-9578$ \\
\hline (30) Launch Energy Star Transtormers & Linda Latham & EPA & $202-233-9420$ & 202-233-9578 \\
\hline $\begin{array}{l}\text { (31) Reduce Eloctrio Ceneration Loseses Through Trenemisaion } \\
\text { Pricing Rolorm }\end{array}$ & Creg Bashoda & DOE & $202-686-4871$ & $202.586-0328$ \\
\hline (32) Expand "Natural Cas Star" & Andrea Orbome & EPA & $202-233-0044$ & $202-283-9569$ \\
\hline (33) Increase Stringency of Landill Rubs & Mark Najarian & EPA & $919-541-5893$ & 019.541 .4028 \\
\hline (34) Expand Landiill Outreach Progrem & Cindy Jacobs & EPA & $202-203-9042$ & $202-283-9560$ \\
\hline (35) Lunch Coabed Mothane Outreach Program & Dina Kruger & EPA & $202-283-9000$ & $202-283-9860$ \\
\hline (36) Expand ROAD for Mothane Recovery from Cool Mining & Dick Ball & DOE & 202-596-5278 & $202-898-2032$ \\
\hline (37) Expend RD\&D for Mothane Recovery from Lendills & Dick Ball & DOE & $202-586-5278$ & $202 \cdot 598-2032$ \\
\hline \multirow{2}{*}{ (38) Expand AgStar Pertnerchip Program with Livestock Producors } & Kunt Rose & EPA & $202-203-8041$ & 202-203-0580 \\
\hline & Carol Whitman & USDA & $703-235-9018$ & $700-235-0046$ \\
\hline \multirow{2}{*}{ (39) Improve Ruminant Productivity and Product Marketing } & Mark Orich & EPA & $202 \cdot 233-9043$ & $202-228-9800$ \\
\hline & Card Whitman & USDA & 703-235-9018 & $705-235-9048$ \\
\hline 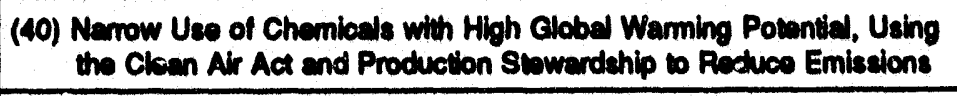 & Jean Lupinacoi & EPA & $202-233-9137$ & $202-238-9670$ \\
\hline $\begin{array}{l}\text { (41) Creats Partnership with Manufecturers of HFC-22 to Eliminate } \\
\text { HCFC-23 Emissions }\end{array}$ & Jean Lupinacci & EPA & $202-233-9137$ & 202.233 .9579 \\
\hline $\begin{array}{l}\text { (42) Launch Partnerahip with Aluminum Proctucers to Roduce Emiseions } \\
\text { from Munutacturing Processes }\end{array}$ & Cindy Jacobs & EPA & 202-230-9042 & $202-283-0500$ \\
\hline (43) Roctuce the Deplotion of Nonindustrial Private Forcests & Card Whituman & USDA & $703-285-9018$ & 708-235-9046 \\
\hline (44) Acosibrab Tree Planing in Nonindustrial Private Foreats & Card Whitman & USDA & $705-285-9018$ & $703-285-8048$ \\
\hline Integrated Analysis of Energy-Rolated Actions & $\begin{array}{l}\text { Abo Haspol } \\
\text { Howard } \\
\text { Cruenspecht } \\
\text { John Cond } \\
\text { Mark Chupka }\end{array}$ & DOE & \begin{tabular}{|l|}
$202-588-6816$ \\
$202-588-4767$ \\
$202-688-4480$ \\
$202-686-6800$
\end{tabular} & $\begin{array}{l}202-688-8047 \\
202-683-6801 \\
202 \cdot 586-8901 \\
202-688-6031\end{array}$ \\
\hline
\end{tabular}




\section{Appendlx D. Condensed Model Report, 1990 and 2000}

This appendix includes historical information for 1990 and projections from the Integrated Dynamic Energy Analysis Simulation (IDEAS) model for the Administration Baseline and the Combined Policy Case (i.e., the effects of the Climate Change Action Plan) for the year 2000. Historical data for 1990 were obtained from the Annual Energy Outlook 1993 (AEO93). ${ }^{33}$ All historical data are consistent with the AEO93, except for carbon emissions data, which were obtained from Emissions of Greenhouse Gases in the United States 1985-1990.

Table D1. Key Economic Data and Assumptlons

\begin{tabular}{|c|c|c|c|}
\hline 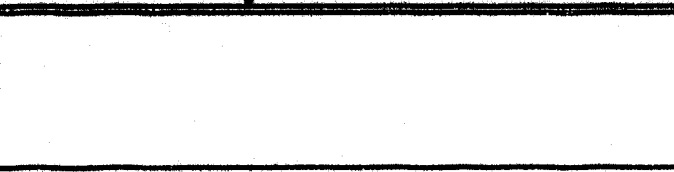 & 1990 & $\begin{array}{c}2000 \\
\text { Adminibtration } \\
\text { Breoline } \\
\end{array}$ & $\begin{array}{l}2000 \\
\text { Combined } \\
\text { Polloy Cese }\end{array}$ \\
\hline Grose Domostic Product (billion 1987 dollars) & 4,887 & 6,153 & 6,153 \\
\hline Cross Domeatic Product (billion 1991 dollars) & 5,705 & 7,168 & 7,168 \\
\hline Population (million) & 251 & 269 & 268 \\
\hline Dieposable Income (billion 1991 dollars) & 4,122 & 4,811 & 4,811 \\
\hline Housing Stock (million) & 93.4 & 102.0 & 102.0 \\
\hline Commercial Fbor Space (billion square foet) & 62.9 & 71.9 & 71.9 \\
\hline Industrial Production Index $(1985=100)$ & 115.6 & 147.2 & 147.2 \\
\hline
\end{tabular}

33. Energy Information Administration, Annual Energy Outlook 1993, DOE/EIA-0383(93) (Washington, DC, Jan. 1993). 34. Energy Information Adminiatration, Emisaions of Greenhouse Gases in the United States 1985-1990, DOE/EIA-0573 (Washington, DC, (nt. 1993). 

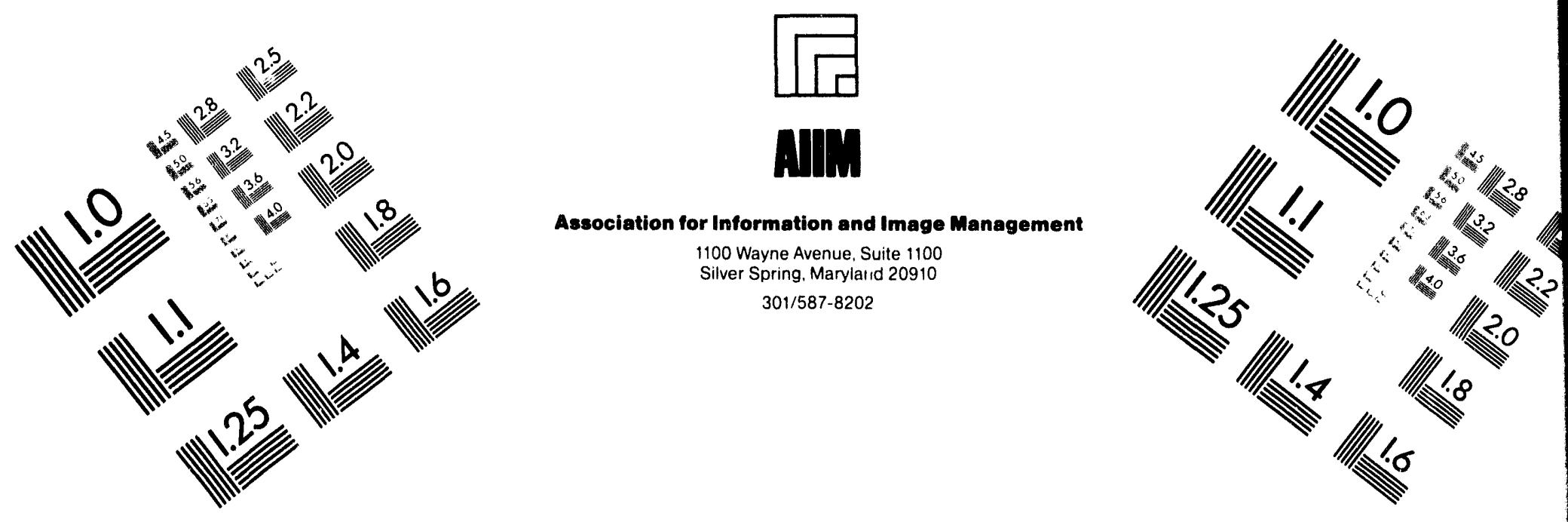

\section{Centimeter}

|

Inches
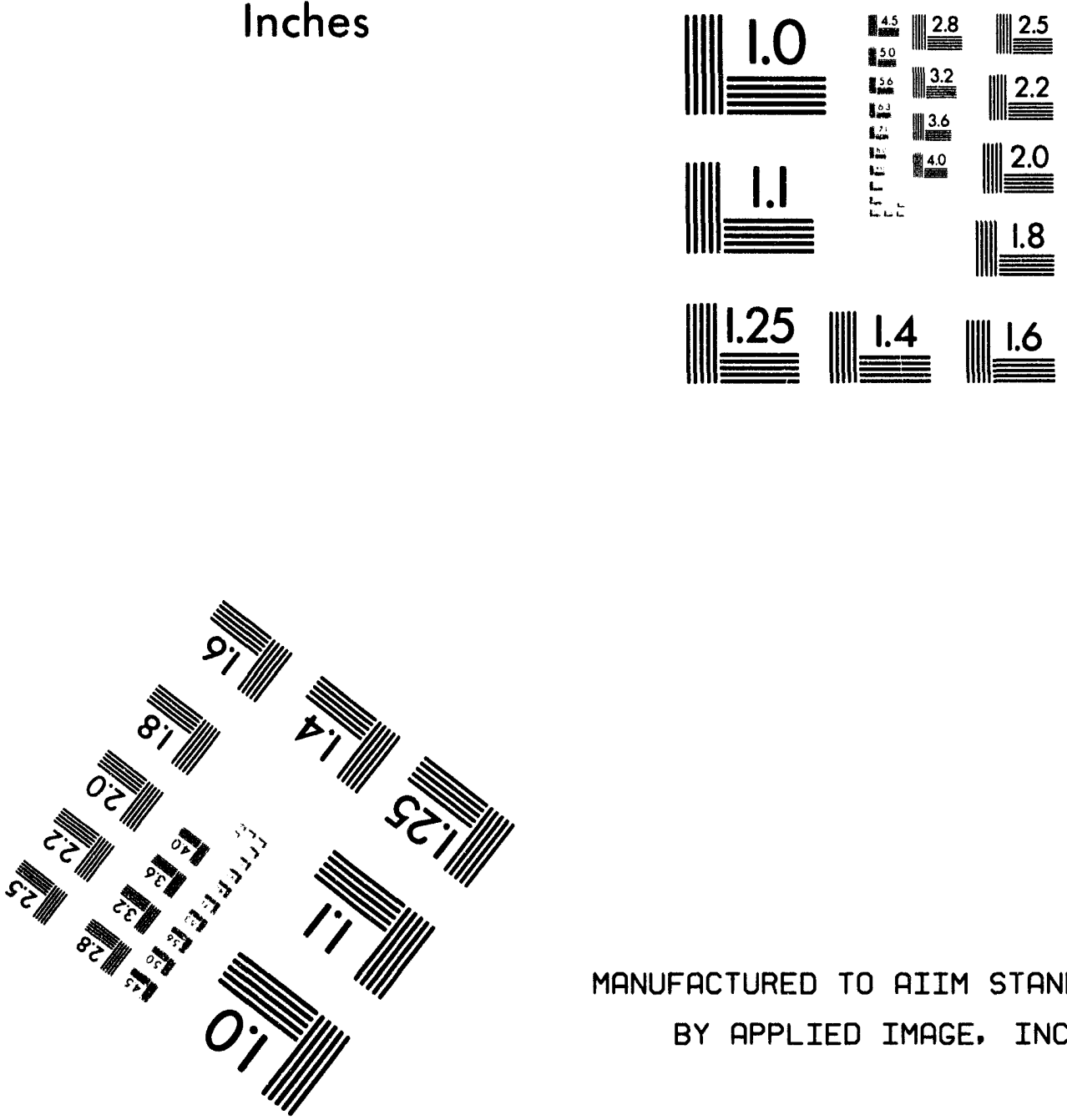

MANUFACTURED TO AIIM STANDARDS

BY APPLIED IMAGE, INC.

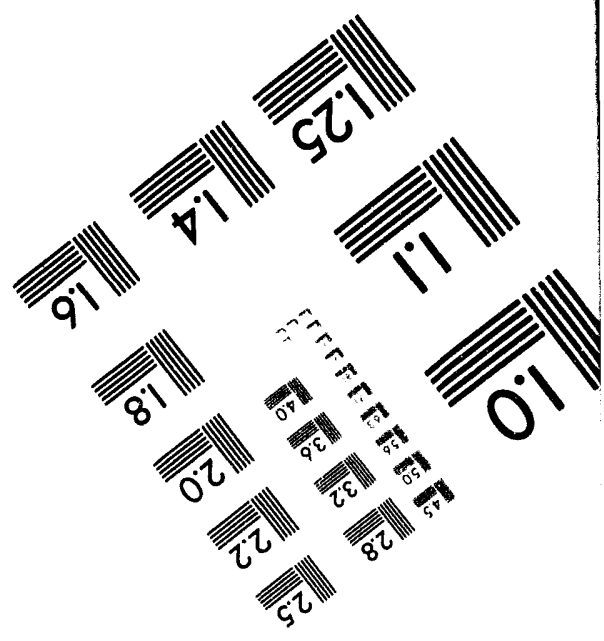



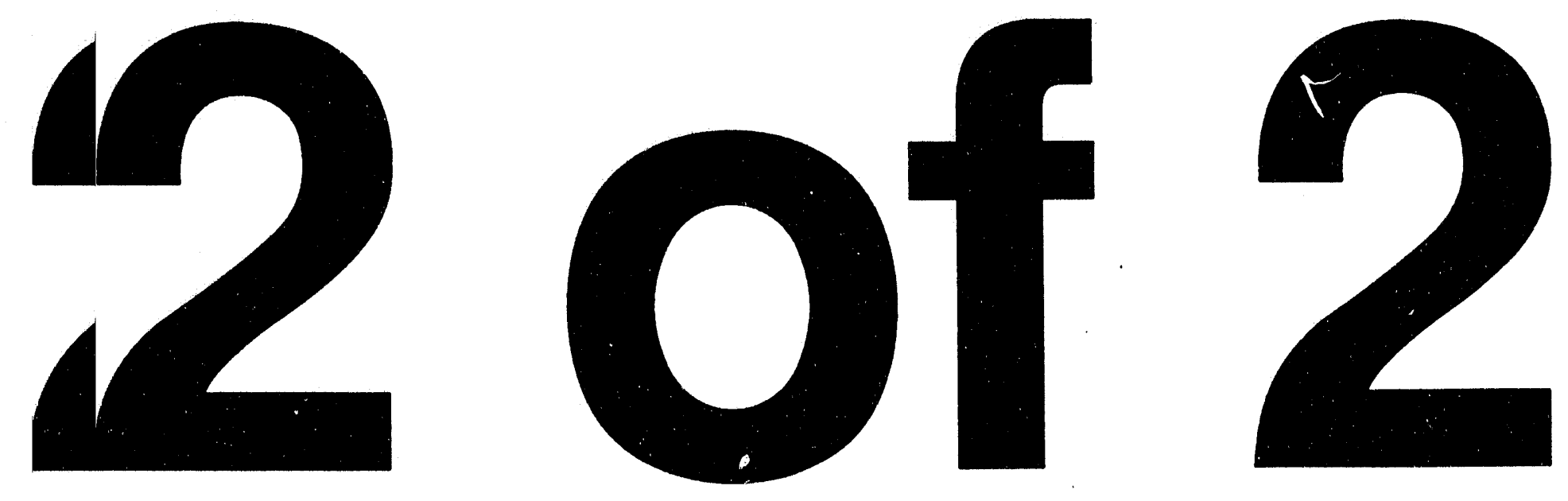
Table D2. Primary Energy Consumption and Production (Quadrillion Btu)

\begin{tabular}{|c|c|c|c|}
\hline & 1990 & $\begin{array}{c}2000 \\
\text { Administration } \\
\text { Baseline }\end{array}$ & $\begin{array}{c}2000 \\
\text { Combined } \\
\text { Policy Case }\end{array}$ \\
\hline \multicolumn{4}{|c|}{ Primary Energy Consumption } \\
\hline Oil & 33.53 & 36.58 & 35.74 \\
\hline Gas & 19.31 & 22.82 & 22.88 \\
\hline Coal & 19.11 & 19.45 & 17.50 \\
\hline Nuclear & 6.19 & 6.74 & 6.74 \\
\hline Renewable & 6.50 & 8.23 & 8.29 \\
\hline Alcohol & 0.00 & 0.02 & 0.02 \\
\hline Net Electricity Imports & 0.11 & 0.20 & 0.20 \\
\hline Total & 84.75 & 94.06 & 91.37 \\
\hline Energy Intensity (Btu per dollar GDP in 1991 dollars) & 14,855 & 13,122 & 12,747 \\
\hline \multicolumn{4}{|c|}{ Primary Domestic Energy Production and Imports } \\
\hline \multicolumn{4}{|l|}{ Production } \\
\hline Oil & 17.91 & 14.65 & 14.63 \\
\hline Gas & 18.47 & 19.70 & 19.75 \\
\hline Coal & 22.23 & 22.82 & 20.87 \\
\hline Nuclear & 6.19 & 6.74 & 6.74 \\
\hline Renewable & 6.53 & 8.23 & 8.29 \\
\hline Alcohol & 0.00 & 0.02 & 0.02 \\
\hline Total & 71.34 & 72.17 & 70.31 \\
\hline \multicolumn{4}{|l|}{ Net Imports } \\
\hline Oil & 15.31 & 21.99 & 21.16 \\
\hline Gas & 1.46 & 3.01 & 3.01 \\
\hline Coal & -2.56 & -3.32 & -3.32 \\
\hline Alcohol/Other & 0.02 & 0.20 & 0.20 \\
\hline Total & 14.23 & 21.88 & 21.06 \\
\hline \multicolumn{4}{|l|}{ Adjustments } \\
\hline Oil & 0.30 & 0.00 & 0.00 \\
\hline Gas & -0.30 & 0.00 & 0.00 \\
\hline Coal & -0.60 & 0.00 & 0.00 \\
\hline Other & -0.22 & 0.00 & 0.00 \\
\hline Total & -0.82 & 0.00 & 0.00 \\
\hline Total Enorgy Supplied & 84.75 & 94.05 & 91.36 \\
\hline
\end{tabular}

Note: Totals may not equal sum of components due to independent rounding. 
Table D3. Energy Prices by Sector

\begin{tabular}{|c|c|c|c|}
\hline & 1990 & $\begin{array}{c}2000 \\
\begin{array}{c}\text { Administration } \\
\text { Baseline }\end{array}\end{array}$ & $\begin{array}{c}2000 \\
\text { Combined } \\
\text { Policy Case }\end{array}$ \\
\hline \multicolumn{4}{|c|}{ Energy Prices (1991 dollars per quadrillion Btu) } \\
\hline \multicolumn{4}{|l|}{ Resource Prices } \\
\hline Refiner Crude & $\$ 3.89$ & $\$ 3.88$ & $\$ 3.84$ \\
\hline Wellhead Gas & $\$ 1.72$ & $\$ 2.39$ & $\$ 2.46$ \\
\hline Minemouth Coal & $\$ 1.02$ & $\$ 1.21$ & $\$ 1.19$ \\
\hline \multicolumn{4}{|l|}{ Residential } \\
\hline Distillate & $\$ 8.08$ & $\$ 7.71$ & $\$ 7.68$ \\
\hline Other Liquid Fuels & $\$ 11.20$ & $\$ 10.97$ & $\$ 10.93$ \\
\hline Natural Gas & $\$ 5.82$ & $\$ 6.52$ & $\$ 6.54$ \\
\hline Electricity & $\$ 23.34$ & $\$ 24.47$ & $\$ 25.07$ \\
\hline \multicolumn{4}{|l|}{ Commercial } \\
\hline Distillate & $\$ 5.94$ & $\$ 5.53$ & $\$ 5.49$ \\
\hline Residual Fuel Oil & $\$ 3.57$ & $\$ 3.80$ & $\$ 3.76$ \\
\hline Natural Gas & $\$ 4.84$ & $\$ 5.61$ & $\$ 5.64$ \\
\hline Electricity & $\$ 22.04$ & $\$ 22.61$ & $\$ 23.16$ \\
\hline \multicolumn{4}{|l|}{ Industrial } \\
\hline Distillate & $\$ 5.94$ & $\$ 5.47$ & $\$ 5.43$ \\
\hline Residual Fuel Oil & $\$ 3.13$ & $\$ 3.49$ & $\$ 3.46$ \\
\hline Other Liquid Fuels & $\$ 5.95$ & $\$ 6.54$ & $\$ 6.50$ \\
\hline Natural Gas Boiler & $\$ 2.95$ & $\$ 3.72$ & $\$ 3.78$ \\
\hline Natural Gas Non-boiler & $\$ 2.95$ & $\$ 3.72$ & $\$ 3.78$ \\
\hline Steam Coal & $\$ 1.48$ & $\$ 1.67$ & $\$ 1.65$ \\
\hline Electricity & $\$ 14.74$ & $\$ 15.56$ & $\$ 15.94$ \\
\hline \multicolumn{4}{|l|}{ Transportation } \\
\hline Gasoline & $\$ 9.86$ & $\$ 10.91$ & $\$ 11.08$ \\
\hline Diesel & $\$ 8.98$ & $\$ 9.76$ & $\$ 9.93$ \\
\hline Residual Fuel Oil & $\$ 3.22$ & $\$ 3.49$ & $\$ 3.46$ \\
\hline Jet Fuel & $\$ 6.00$ & $\$ 5.43$ & $\$ 5.40$ \\
\hline \multicolumn{4}{|l|}{ Utility Sector } \\
\hline Other Liquid Fuels & $\$ 3.61$ & $\$ 3.98$ & $\$ 3.94$ \\
\hline Natural Gas & $\$ 2.38$ & $\$ 3.07$ & $\$ 3.14$ \\
\hline Steam Coal & $\$ 1.45$ & $\$ 1.68$ & $\$ 1.66$ \\
\hline Nuclear & $\$ 0.82$ & $\$ 0.67$ & $\$ 0.67$ \\
\hline Average Electricity Price & $\$ 19.94$ & $\$ 20.74$ & $\$ 21.25$ \\
\hline \multicolumn{4}{|c|}{ Energy Prices (1991 dollars per physical unit) } \\
\hline \multicolumn{4}{|l|}{ Resource } \\
\hline World Oil Price (dollars per barrel) & $\$ 22.54$ & $\$ 22.48$ & $\$ 22.28$ \\
\hline Wollhead Natural Gas (dollars per thousand cubic feet) & $\$ 1.77$ & $\$ 2.47$ & $\$ 2.53$ \\
\hline Minemouth Coal (dollars per ton) & $\$ 22.52$ & $\$ 26.39$ & $\$ 25.97$ \\
\hline \multicolumn{4}{|l|}{ End-Use } \\
\hline Average Price Electricity (cents per kilowatthour) & 6.8 & 7.1 & 7.3 \\
\hline Average Price Gasoline (dollars per gallon) & $\$ 1.23$ & $\$ 1.36$ & $\$ 1.39$ \\
\hline
\end{tabular}

Note: Totals may not equal sum of components due to independent rounding. 
Table D4. End-Use Energy Consumed by FInal Customer (Quadrillion Btu)

\begin{tabular}{|c|c|c|c|}
\hline & 1990 & $\begin{array}{c}2000 \\
\text { Administration } \\
\text { Baseline }\end{array}$ & $\begin{array}{c}2000 \\
\text { Combined } \\
\text { Policy Case }\end{array}$ \\
\hline \multicolumn{4}{|c|}{ Consumption by Soctor } \\
\hline Residential & 9.83 & 11.28 & 10.89 \\
\hline Commercial & 6.73 & 6.78 & 6.56 \\
\hline Industrial & 24.84 & 27.52 & 26.96 \\
\hline Transportation & 22.50 & 25.67 & 25.33 \\
\hline Total End-Use Consumption & 63.89 & 71.26 & 69.74 \\
\hline Transmission and Distribution Losses & -20.86 & -22.80 & -21.63 \\
\hline Total Primary Consumption & 84.75 & 94.06 & 91.37 \\
\hline \multicolumn{4}{|c|}{ Enorgy Used by Final Consumer (Excluding Inputs to Utilities) } \\
\hline Oil & 32.30 & 35.27 & 34.43 \\
\hline Natural Gas & 16.43 & 19.02 & 18.90 \\
\hline Coal & 2.91 & 2.85 & 2.83 \\
\hline Electricity & 9.26 & 10.23 & 9.75 \\
\hline Renewables & 3.00 & 3.87 & 3.81 \\
\hline Alcohol & 0.00 & 0.02 & 0.02 \\
\hline Total End-Use Consumption & 63.89 & 71.26 & 69.74 \\
\hline Transmission and Distribution Losses & -20.86 & -22.80 & -21.63 \\
\hline Total Primary Consumption & 84.75 & 94.06 & 91.37 \\
\hline
\end{tabular}

Note: Totals may not equal sum of components due to independent rounding. 
Table D5. Oll Consumption and Production (Million Barrels per Day)

\begin{tabular}{|c|c|c|c|}
\hline & 1990 & $\begin{array}{c}2000 \\
\text { Administration } \\
\text { Baseline }\end{array}$ & $\begin{array}{c}2000 \\
\text { Combined } \\
\text { Policy Case }\end{array}$ \\
\hline \multicolumn{4}{|c|}{ Indigenous Oil Production } \\
\hline Lower 48 & 5.58 & 4.27 & 4.27 \\
\hline Alaska & 1.77 & 0.93 & 0.93 \\
\hline Enhanced Oil Recovery & 0.77 & 0.66 & 0.66 \\
\hline Natural Gas Liquids & 1.56 & 1.60 & 1.60 \\
\hline Total Oil Production & 9.68 & 7.47 & 7.46 \\
\hline \multicolumn{4}{|c|}{ Other Sources } \\
\hline Net Oil Imports & 7.17 & 10.15 & 9.77 \\
\hline Other & 0.78 & 0.81 & 0.79 \\
\hline Total Imports and Stock Changes & 7.95 & 10.97 & 10.56 \\
\hline \multicolumn{4}{|c|}{ Totals } \\
\hline Total Primary Oil Consumption & 17.63 & 18.43 & 18.02 \\
\hline Oil Transformation to Electricity & -0.54 & -0.56 & -0.56 \\
\hline Oil Transformation to Gas & 0.00 & -0.04 & -0.04 \\
\hline Total End-Use Oil Consumption & 17.09 & 17.80 & 17.39 \\
\hline
\end{tabular}

Note: Totals may not equal sum of components due to independent rounding. 
Table D6. Gas Consumption and Production (Trillion Cublc Feet)

\begin{tabular}{|c|c|c|c|}
\hline & 1990 & $\begin{array}{c}2000 \\
\begin{array}{c}\text { Administration } \\
\text { Baseline }\end{array}\end{array}$ & $\begin{array}{c}2000 \\
\text { Combined } \\
\text { Policy Case }\end{array}$ \\
\hline \multicolumn{4}{|c|}{ Indigenous Production of Conventional Gas } \\
\hline Conventional Gas Production & 17.81 & 19.11 & 19.15 \\
\hline \multicolumn{4}{|c|}{ Additional Sources of Conventional Gas } \\
\hline Pipeline & 1.45 & 2.16 & 2.16 \\
\hline Liquefied Natural Gas & 0.00 & 0.76 & 0.76 \\
\hline Stock Change & -0.51 & 0.00 & 0.00 \\
\hline Total Imports and Other & 0.94 & 2.92 & 2.92 \\
\hline Total Conventional Gas Consumption & 18.75 & 22.03 & 22.07 \\
\hline \multicolumn{4}{|c|}{ Transformation to or from Gas } \\
\hline Synthetic from Oil & 0.10 & 0.06 & 0.06 \\
\hline Synthetic from Coal & 0.00 & 0.05 & 0.05 \\
\hline Total Synthetics & 0.10 & 0.11 & 0.11 \\
\hline io Electricity & -2.79 & -3.80 & -3.98 \\
\hline Total Gas Used by Final Consumers & 16.06 & 18.33 & 18.20 \\
\hline Total Primary Gas Consumed & 18.85 & 22.14 & 22.18 \\
\hline
\end{tabular}

Note: Totals may not equal sum of components due to independent rounding. 
Table D7. Coal Consumption and Production

\begin{tabular}{|c|c|c|c|}
\hline & 1990 & $\begin{array}{c}2000 \\
\text { Administration } \\
\text { Baseline }\end{array}$ & $\begin{array}{c}2000 \\
\text { Combined } \\
\text { Policy Case }\end{array}$ \\
\hline \multicolumn{4}{|c|}{ Coal Production and Consumption (quadrillion Btu) } \\
\hline Total Primary Production & 22.23 & 22.82 & 20.87 \\
\hline Net Imports & -2.56 & -3.32 & -3.32 \\
\hline Stock Changes & -0.56 & 0.00 & 0.00 \\
\hline Other & 0.00 & 0.00 & 0.00 \\
\hline Total Primary Consumption & 19.11 & 19.50 & 17.55 \\
\hline Transformation to Electricity & 16.10 & 16.58 & 14.65 \\
\hline Transformation to Synthetic Fuels & 0.10 & 0.08 & 0.08 \\
\hline Coal Used by Final Consumers & 2.91 & 2.85 & 2.83 \\
\hline \multicolumn{4}{|c|}{ Coal Production and Consumption (million short tons) } \\
\hline Total Primary Production & $1,029.0$ & $1,070.2$ & 976.9 \\
\hline Net Imports & -103.0 & -126.7 & -126.7 \\
\hline Stock Changes & -27.0 & 0.0 & 0.0 \\
\hline Other & 0.0 & 0.0 & 0.0 \\
\hline Total Primary Consumption & 899.0 & 943.5 & 850.3 \\
\hline Transformation to Electricity & 774.0 & 792.2 & 699.8 \\
\hline Transformation to Synthetic Fuels & 4.4 & 3.6 & 3.6 \\
\hline Coal Used by Final Consumers & 120.6 & 147.8 & 146.9 \\
\hline
\end{tabular}

Note: Totals may not equal sum of components due to independent rounding. 
Table D8. Renewable Energy Consumption and Production (Quadrillion Btu)

\begin{tabular}{|c|c|c|c|}
\hline & 1990 & $\begin{array}{c}2000 \\
\text { Administration } \\
\text { Baseline }\end{array}$ & $\begin{array}{c}2000 \\
\text { Combined } \\
\text { Policy Case }\end{array}$ \\
\hline \multicolumn{4}{|c|}{ Renowable Inputs to Electricity Generation } \\
\hline Hydropower & 2.99 & 3.20 & 3.28 \\
\hline Geothermal & 0.16 & 0.29 & 0.30 \\
\hline Biomass & 0.32 & 0.78 & 0.78 \\
\hline Municipal Solid Waste & 0.11 & 0.00 & 0.00 \\
\hline Solar Thermal & 0.01 & 0.02 & 0.02 \\
\hline Solar Photovoltaic & 0.00 & 0.00 & 0.00 \\
\hline Wind & 0.02 & 0.08 & 0.10 \\
\hline Total & 3.62 & 4.37 & 4.48 \\
\hline \multicolumn{4}{|c|}{ Ronowable Enorgy Used by Final Consumers } \\
\hline Biomass Wood & 2.58 & 2.98 & 2.92 \\
\hline Other & 0.06 & 0.27 & 0.27 \\
\hline Active/Passive Solar & 0.05 & 0.22 & 0.22 \\
\hline Geothermal & 0.00 & 0.40 & 0.40 \\
\hline Solar Photovoltaic & 0.00 & 0.00 & 0.00 \\
\hline Wind & 0.00 & 0.00 & 0.00 \\
\hline Total & 2.69 & 3.87 & 3.81 \\
\hline Primary Ronowables Total & $\mathbf{6 . 3 1}$ & 8.23 & 8.29 \\
\hline
\end{tabular}

Note: Totals may not equal sum of components due to independent rounding. 
Table D9. Alcohol Consumption (Quadrillion Btu)

\begin{tabular}{|c|c|c|c|}
\hline & 1990 & $\begin{array}{c}2000 \\
\text { Administration } \\
\text { Baseline }\end{array}$ & $\begin{array}{c}2000 \\
\text { Combined } \\
\text { Policy Case }\end{array}$ \\
\hline \multicolumn{4}{|l|}{ Mbthanol } \\
\hline Biomass Derived & 0.00 & 0.02 & 0.02 \\
\hline Gas Derived & 0.00 & 0.00 & 0.00 \\
\hline Total Mothanol & 0.00 & 0.02 & 0.02 \\
\hline \multicolumn{4}{|l|}{ Ethanol } \\
\hline Biomass Derived & 0.00 & 0.00 & 0.00 \\
\hline Gas Derived & 0.00 & 0.00 & 0.00 \\
\hline Total Ethanol & 0.00 & 0.00 & 0.00 \\
\hline \multicolumn{4}{|l|}{ Total Alcohol } \\
\hline Biomass Derived & 0.00 & 0.02 & 0.02 \\
\hline Gas Derived & 0.00 & 0.00 & 0.00 \\
\hline Total Alcohol Consumption & 0.00 & 0.02 & 0.02 \\
\hline
\end{tabular}

Note: Totals may not equal sum of components due to independent rounding. 
The Climate Change Action Plan: Technical Supplement

Table D10. Energy Consumption In Bulldings

\begin{tabular}{|c|c|c|c|}
\hline & 1990 & $\begin{array}{c}2000 \\
\begin{array}{c}\text { Administration } \\
\text { Baseline }\end{array}\end{array}$ & $\begin{array}{c}2000 \\
\text { Combined } \\
\text { Policy Case } \\
\end{array}$ \\
\hline \multicolumn{4}{|c|}{ Residential Energy Use (quadrillion Btu) } \\
\hline Oil & 1.27 & 1.13 & 1.08 \\
\hline Natural Gas & 4.52 & 5.07 & 4.90 \\
\hline Coal & 0.06 & 0.12 & 0.11 \\
\hline Electricity & 3.15 & 3.49 & 3.32 \\
\hline Renewable & 0.83 & 1.48 & 1.48 \\
\hline Total & 9.83 & 11.28 & 10.89 \\
\hline \multicolumn{4}{|c|}{ Commercial Enorgy Uso (quadrillion Btu) } \\
\hline Oil & 0.91 & 0.72 & 0.69 \\
\hline Natural Gas & 2.76 & 2.94 & 2.87 \\
\hline Coal & 0.10 & 0.07 & 0.07 \\
\hline Electricity & 2.86 & 2.88 & 2.76 \\
\hline Renewable & 0.10 & 0.17 & 0.17 \\
\hline Total & 6.73 & 6.78 & 6.56 \\
\hline \multicolumn{4}{|c|}{ Physical Units } \\
\hline \multicolumn{4}{|l|}{ Residential } \\
\hline Oil (million barrels per day) & 0.67 & 0.53 & 0.51 \\
\hline Gas (trillion cubic foet) & 4.46 & 4.92 & 4.75 \\
\hline Electricity (billion kilowatthours) & 923.0 & 1022.5 & 973.5 \\
\hline \multicolumn{4}{|l|}{ Commercial } \\
\hline Oil (million barrels per day) & 0.48 & 0.33 & 0.32 \\
\hline Gas (trillion cubic feet) & 2.72 & 2.85 & 2.78 \\
\hline Electricity (billion kilowatthours) & 838.0 & 844.7 & 808.9 \\
\hline
\end{tabular}

Note: Totals may not equal sum of components due to independent rounding. 
Table D11. Energy/Non-Energy Consumption In Industrlal (Quadrillion Btu)

\begin{tabular}{|c|c|c|c|}
\hline & 1990 & $\begin{array}{c}2000 \\
\text { Administration } \\
\text { Baseline }\end{array}$ & $\begin{array}{c}2000 \\
\text { Combined } \\
\text { Policy Case }\end{array}$ \\
\hline \multicolumn{4}{|c|}{ Energy Use (Excluding Non-Energy Feedstocks) } \\
\hline Oil & 4.49 & 4.09 & 3.68 \\
\hline Gas & 7.34 & 9.07 & 9.16 \\
\hline Coal & 1.71 & 1.69 & 1.67 \\
\hline Electricity & 3.23 & 3.72 & 3.53 \\
\hline Renewable & 2.07 & 2.22 & 2.16 \\
\hline Total & 17.83 & 20.78 & 20.21 \\
\hline \multicolumn{4}{|c|}{ Non-Energy Use } \\
\hline Asphalt & 1.29 & 1.31 & 1.31 \\
\hline Other & 2.53 & 3.30 & 3.31 \\
\hline Subtotal & 4.93 & 4.61 & 4.62 \\
\hline Gases & 1.13 & 1.16 & 1.16 \\
\hline Metallurgical Coal & 1.04 & 0.97 & 0.98 \\
\hline Total & 7.01 & 6.74 & 6.75 \\
\hline \multicolumn{4}{|c|}{ Energy and Non-Energy Use } \\
\hline Oil & 8.31 & 8.70 & 8.29 \\
\hline Gas & 8.47 & 10.23 & 10.32 \\
\hline Coal & 2.75 & 2.66 & 2.65 \\
\hline Electricity & 3.23 & 3.72 & 3.53 \\
\hline Renewable & 2.07 & 2.22 & 2.16 \\
\hline Total Primary Energy & 24.84 & 27.52 & 26.96 \\
\hline
\end{tabular}

Note: Totals may not equal sum of components due to independent rounding. 
Table D12. Energy Consumption In Transportation

\begin{tabular}{|c|c|c|c|}
\hline & 1990 & $\begin{array}{c}2000 \\
\text { Administration } \\
\text { Baseline }\end{array}$ & $\begin{array}{c}2000 \\
\text { Combined } \\
\text { Policy Case }\end{array}$ \\
\hline \multicolumn{4}{|c|}{ Transportation Energy Consumption (Quadrillion Btu) } \\
\hline Oil & 21.80 & 24.73 & 24.36 \\
\hline Motor Gasoline & 13.58 & 15.48 & 15.16 \\
\hline Diesel & 3.83 & 4.27 & 4.23 \\
\hline Jot Fuel & 3.13 & 3.59 & 3.59 \\
\hline Residual Fuel & 1.02 & 1.23 & 1.23 \\
\hline Other & 0.24 & 0.15 & 0.15 \\
\hline Mothanol & 0.00 & 0.02 & 0.02 \\
\hline Ethanol & 0.00 & 0.00 & 0.00 \\
\hline Natural Gas & 0.68 & 0.78 & 0.81 \\
\hline Electricity & 0.01 & 0.14 & 0.14 \\
\hline Coal & 0.00 & 0.00 & 0.00 \\
\hline Total Consumption & 22.50 & 25.67 & 25.33 \\
\hline \multicolumn{4}{|c|}{ Additional Data-Transportation Sector } \\
\hline \multicolumn{4}{|l|}{ Light-Duty Vohiclos } \\
\hline Operating Vehicles (million) & 169.9 & 201.8 & 201.5 \\
\hline Vehicle Miles Traveled (billion) & 2030 & 2515 & 2470 \\
\hline Fleet Efficiency (on-road miles per gallon) & 19.4 & 26.1 & 26.2 \\
\hline Fuel Consumption (quadrillion Btu) & 13.14 & 15.18 & 14.87 \\
\hline \multicolumn{4}{|l|}{ Heavy-Duty Vehiclos } \\
\hline Operating Vehicles (million) & 4.4 & 5.1 & 5.1 \\
\hline Vehicle Miles Traveled (billion) & 138 & 177 & 177 \\
\hline Fleet Efficiency (on-road miles per gallon) & 5.8 & 7.3 & 7.3 \\
\hline Fuel Consumption (quadrillion Btu) & 3.32 & 3.38 & 3.35 \\
\hline \multicolumn{4}{|l|}{ Air Travel } \\
\hline Passenger Revenue Miles (billion) & 340 & 685 & 685 \\
\hline Fleet Efficiency Indexed to 1990 & 1.00 & 1.16 & 1.16 \\
\hline Fuel Consumption (quadrillion Btu) & 3.20 & 3.74 & 3.74 \\
\hline \multicolumn{4}{|l|}{ Railroads } \\
\hline Rail Froight Ton-Miles & 967 & 1073 & 1070 \\
\hline Fuel Efficiency Indexed to 1990 & 1.00 & 1.04 & 1.05 \\
\hline Fuol Consumption (quadrillion Btu) & 0.49 & 0.51 & 0.51 \\
\hline \multicolumn{4}{|l|}{ Other } \\
\hline Waterborne Fuel Consumption (quadrillion Btu) & 1.39 & 1.92 & 1.92 \\
\hline Pipoline Fuel Consumption (quadrillion Btu) & 0.68 & 0.75 & 0.75 \\
\hline Other Modes Fuel Consumption (quadrillion Btu) & 0.17 & 0.19 & 0.19 \\
\hline
\end{tabular}

Note: Totals may not equal sum of components due to independent rounding. 
Table D13. Transportation Energy Consumption In Physical Units

\begin{tabular}{|c|c|c|c|}
\hline & 1990 & $\begin{array}{c}2000 \\
\begin{array}{c}\text { Administration } \\
\text { Baseline }\end{array}\end{array}$ & $\begin{array}{c}2000 \\
\text { Combined } \\
\text { Policy Case }\end{array}$ \\
\hline \multicolumn{4}{|c|}{ Transportation Energy Consumption } \\
\hline Oil (million barrels per day) & 10.95 & 12.46 & 12.27 \\
\hline Motor Gasoline & 7.08 & 8.07 & 7.91 \\
\hline Diesel & 1.80 & 2.01 & 1.99 \\
\hline Jet Fuel & 1.51 & 1.76 & 1.76 \\
\hline Residual Fuel & 0.44 & 0.54 & 0.54 \\
\hline Other & 0.12 & 0.08 & 0.08 \\
\hline Mothanol (million barrels per cay) & 0.00 & 0.02 & 0.02 \\
\hline Ethanol (million barrels per day) & 0.00 & 0.00 & 0.00 \\
\hline Natural Gas (trillion cubic foet) & 0.67 & 0.76 & 0.79 \\
\hline Electricity (billion kilowatthours) & 2.93 & 40.12 & 39.87 \\
\hline Coal (million short tons) & 0.00 & 0.00 & 0.00 \\
\hline \multicolumn{4}{|c|}{ Additional Dato-Transportation Sector } \\
\hline \multicolumn{4}{|l|}{ Light-Duty Vehicles } \\
\hline Operating Vehicles (million) & 169.9 & 201.8 & 201.5 \\
\hline Vehicle Miles Traveled (billion) & 2030 & 2515 & 2470 \\
\hline Fleet Efficiency (on-road miles per gallon) & 19.4 & 26.1 & 26.2 \\
\hline Fuel Consumption (million barrels oil equivalent) & 2265 & 2617 & 2564 \\
\hline \multicolumn{4}{|l|}{ Heavy-Duty Vehicles } \\
\hline Operating Vehicles (million) & 4.4 & 5.1 & 5.1 \\
\hline Vehicle Miles Traveled (billion) & 138 & 177 & 177 \\
\hline Fleet Efficiency (on-road miles per gallon) & 5.8 & 7.3 & 7.3 \\
\hline Fuel Consumption (million barrels oil equivalent) & 572 & 582 & 577 \\
\hline \multicolumn{4}{|l|}{ Air Travel } \\
\hline Passenger Revenue Miles (billion) & 340 & 685 & 685 \\
\hline Floet Efficiency Indexed to 1990 & 1.00 & 1.16 & 1.16 \\
\hline Fuel Consumption (million barrels oil equivalent) & 552 & 645 & 646 \\
\hline \multicolumn{4}{|l|}{ Railroads } \\
\hline Rail Freight Ton-Miles & 967 & 1073 & 1070 \\
\hline Fuel Efficiency Indexed to 1990 & 1.00 & 1.04 & 1.05 \\
\hline Fuel Consumption (million barrels oil equivalent) & 84.0 & 88.4 & 88.1 \\
\hline \multicolumn{4}{|l|}{ Other } \\
\hline Waterborne Fuel Consumption (million barrels oil equivalent) & 240.0 & 331.0 & 330.3 \\
\hline Pipeline Fuel Consuinption (million barrels oil equivalent) & 117.0 & 128.6 & 128.9 \\
\hline Other Modes Fuel Consumption (million barrels oil equivalent) & 29.0 & 32.8 & 32.8 \\
\hline
\end{tabular}

Note: Totals may not equal sum of components due to independent rounding. 
The Climate Change Action Plan: Technical Supplement

Table D14. Primary Inputs to Electriclty Generation and Sales

\begin{tabular}{|c|c|c|c|}
\hline & 1990 & $\begin{array}{c}2000 \\
\begin{array}{c}\text { Administration } \\
\text { Baseline }\end{array}\end{array}$ & $\begin{array}{c}2000 \\
\text { Combined } \\
\text { Pollcy Case }\end{array}$ \\
\hline \multicolumn{4}{|c|}{ Primery Inputs to Utilitios and Non-utilitios } \\
\hline Oil & 1.23 & 1.28 & 1.27 \\
\hline Gas & 2.88 & 3.80 & 3.98 \\
\hline Coal & 16.20 & 16.58 & 14.65 \\
\hline Nucloar & 6.19 & 6.74 & 6.74 \\
\hline Renowable & 3.49 & 4.37 & 4.48 \\
\hline Total Primary Inputs & 29.99 & 32.77 & 31.12 \\
\hline Electricity Losses & 20.75 & 22.74 & 21.57 \\
\hline Not Electricity Imports & 0.02 & 0.20 & 0.20 \\
\hline Total Electricity Salos & 8.26 & 10.23 & 9.75 \\
\hline
\end{tabular}

Note: Totals may not equal sum of components due to independent rounding. 
Table D15. Utility and Non-Utility Net Summer Capacity (Glgawatts)

\begin{tabular}{|c|c|c|c|}
\hline & 1990 & $\begin{array}{c}2000 \\
\text { Administration } \\
\text { Baseline }\end{array}$ & $\begin{array}{l}2000 \\
\text { Combined } \\
\text { Polky Case }\end{array}$ \\
\hline Total Oil & 62.20 & 55.80 & 56.02 \\
\hline Oil Steam & 37.40 & 32.06 & 32.79 \\
\hline Oil Turbine & 24.80 & 23.84 & 23.22 \\
\hline Total Ges & 146.20 & 158.10 & 155.80 \\
\hline Gas Steam & 106.40 & 46.48 & 45.76 \\
\hline Gas Combined Cycle & 18.20 & 67.32 & 66.98 \\
\hline STIGMSTIG & 0.00 & 0.00 & 0.00 \\
\hline Gas Turbine & 21.60 & 44.27 & 43.13 \\
\hline Gas Fuol Colls & 0.00 & 0.00 & 0.00 \\
\hline Other Turbines & 0.00 & 0.00 & 0.00 \\
\hline Total Coal & 305.30 & 320.04 & 319.96 \\
\hline Pulverized Coal & 305.30 & 319.99 & 319.91 \\
\hline Air Fluidized Bed & 0.00 & 0.05 & 0.05 \\
\hline Pressurized Fluidized Bed & 0.00 & 0.00 & 0.00 \\
\hline IGCC & 0.00 & 0.00 & 0.00 \\
\hline Coal ISTIG & 0.00 & 0.00 & 0.00 \\
\hline New Coal Technologies & 0.00 & 0.00 & 0.00 \\
\hline Total Nuclear & 99.60 & 101.74 & 101.74 \\
\hline Light Water & 99.60 & 101.74 & 101.74 \\
\hline Advanced Light Water & 0.00 & 0.00 & 0.00 \\
\hline New Nuclear Technologies & 0.00 & 0.00 & 0.00 \\
\hline Total Renowables & 86.70 & 116.89 & 119.85 \\
\hline Hydropower & 72.20 & 76.91 & 79.91 \\
\hline Pumped and Other Storage & 17.40 & 19.90 & 19.90 \\
\hline Geothermal & 1.80 & 3.85 & 3.85 \\
\hline Solar Photovoltaic & 0.00 & 0.00 & 0.00 \\
\hline Solar Thermal & 0.40 & 0.52 & 0.52 \\
\hline Biomass Wood and Waste & 2.90 & 12.68 & 12.67 \\
\hline Wind & 2.00 & 3.03 & 3.01 \\
\hline Total Capecity & 710.0 & 752.7 & 753.5 \\
\hline
\end{tabular}

Note: Totals may not equal sum of components due to independent rounding. 
Table D16. UtIlity and Non-UtIlity Generation (Thousand Gigawatthours)

\begin{tabular}{|c|c|c|c|}
\hline & 1990 & $\begin{array}{c}2000 \\
\text { Administration } \\
\text { Baseline }\end{array}$ & $\begin{array}{l}2000 \\
\text { Combined } \\
\text { Policy Case }\end{array}$ \\
\hline Total OII & 117.0 & 119.7 & 118.6 \\
\hline Oil Steam & 114.0 & 103.4 & 103.9 \\
\hline Oil Turbine & 3.0 & 16.3 & 15.7 \\
\hline Total Cas & 329.0 & 424.6 & 411.7 \\
\hline Gas Stoam & 240.0 & 149.9 & 145.0 \\
\hline Gas Combined Cycle & 85.0 & 244.4 & 237.6 \\
\hline STIG/STIG & 0.0 & 0.0 & 0.0 \\
\hline Gas Turbine & 4.0 & 30.3 & 29.1 \\
\hline Gas Fuel Colls & 0.0 & 0.0 & 0.0 \\
\hline Other Turbines & 0.0 & 0.0 & 0.0 \\
\hline Total Coal & $1,591.0$ & $1,587.7$ & $1,431.7$ \\
\hline Pulverized Coal & 1591.0 & 1587.3 & 1431.4 \\
\hline Air Fluidized Bed & 0.0 & 0.4 & 0.3 \\
\hline Pressurized Fluidized Bed & 0.0 & 0.0 & 0.0 \\
\hline IGCC & 0.0 & 0.0 & 0.0 \\
\hline Coal ISTIG & 0.0 & 0.0 & 0.0 \\
\hline New Coal Technologies & 0.0 & 0.0 & 0.0 \\
\hline Total Nuclear & 577,0 & 624.4 & 624.4 \\
\hline Light Water & 577.0 & 624.4 & 624.4 \\
\hline Advanced Light Water & 0.0 & 0.0 & 0.0 \\
\hline New Nuclear Technologies & 0.0 & 0.0 & 0.0 \\
\hline Total Renowables & 299.0 & 415.4 & 426.2 \\
\hline Hydropower & 274.0 & 309.9 & 317.8 \\
\hline Pumped and Other Storage & -9.0 & -10.0 & -10.0 \\
\hline Geothermal & 10.0 & 27.9 & 28.8 \\
\hline Solar Photovoltaic & 0.0 & 0.0 & 0.0 \\
\hline Solar Thermal & 1.0 & 1.7 & 1.7 \\
\hline Biomass Wood and Wasto & 18.0 & 78.0 & 77.9 \\
\hline Wind & 5.0 & 8.0 & 10.0 \\
\hline Total Coneration & $2,913.0$ & $3,171.8$ & $3,013.5$ \\
\hline
\end{tabular}

Note: Totals may not equal sum of components due to independent rounding. 
Table D17. U.S. Energy Consumption Sector Summary (Quadrillion Btu)

\begin{tabular}{|c|c|c|c|}
\hline & 1890 & $\begin{array}{c}2000 \\
\text { Administration } \\
\text { Baseline }\end{array}$ & $\begin{array}{c}2000 \\
\text { Combined } \\
\text { Policy Case }\end{array}$ \\
\hline \multicolumn{4}{|c|}{ Residential Total } \\
\hline Liquid Fuels & 1.27 & 1.13 & 1.08 \\
\hline Gas & 4.52 & 5.07 & 4.90 \\
\hline Coal Solids & 0.06 & 0.12 & 0.11 \\
\hline Electric & 3.15 & 3.49 & 3.32 \\
\hline Renewables & 0.83 & 1.48 & 1.48 \\
\hline Total & 9.83 & 11.29 & 10.89 \\
\hline \multicolumn{4}{|c|}{ Commercial Total } \\
\hline Liquid Fuels & 0.91 & 0.72 & 0.69 \\
\hline Gas & 2.76 & 2.94 & 2.87 \\
\hline Coal Solids & 0.10 & 0.07 & 0.07 \\
\hline Electric & 2.86 & 2.88 & 2.76 \\
\hline Renewables & 0.10 & 0.17 & 0.17 \\
\hline Total & 6.73 & 6.78 & 6.56 \\
\hline \multicolumn{4}{|c|}{ Industrial Total } \\
\hline Liquid Fuels & 8.31 & 8.70 & 8.29 \\
\hline Gas & 8.47 & 10.23 & 10.32 \\
\hline Coal Solids & 2.75 & 2.66 & 2.65 \\
\hline Electric & 3.23 & 3.72 & 3.53 \\
\hline Renewables & 2.07 & 2.22 & 2.16 \\
\hline Total & 24.84 & 27.52 & 26.86 \\
\hline \multicolumn{4}{|c|}{ Transportation Total } \\
\hline Oil & 21.80 & 24.73 & 24.36 \\
\hline Motor Gasoline & 13.58 & 15.48 & 15.16 \\
\hline Diesel & 3.83 & 4.27 & 4.23 \\
\hline Jet Fuel & 3.13 & 3.59 & 3.59 \\
\hline Residual & 1.02 & 1.23 & 1.23 \\
\hline Other & 0.24 & 0.15 & 0.15 \\
\hline Alcohol & 0.00 & 0.02 & 0.02 \\
\hline Natural Gas & 0.68 & 0.78 & 0.81 \\
\hline Electricity & 0.01 & 0.14 & 0.14 \\
\hline Total & 22.50 & 25.67 & 25.33 \\
\hline
\end{tabular}

Note: Totals may not equal sum of components due to independent rounding. 
Table D18. Residentlal End-Use Energy Consumption (Quadrillion Btu)

\begin{tabular}{|c|c|c|c|}
\hline & 1990 & $\begin{array}{c}2000 \\
\text { Administration } \\
\text { Baseline }\end{array}$ & $\begin{array}{c}20.00 \\
\text { Combinod } \\
\text { Policy Case }\end{array}$ \\
\hline \multicolumn{4}{|c|}{ Spaco Heating } \\
\hline Liquid Fuels & $n / a$ & 1.10 & 1.05 \\
\hline Gas & $n / a$ & 3.30 & 3.14 \\
\hline Cosl Solids & $n / a$ & 0.11 & 0.11 \\
\hline Electric & $n / a$ & 0.42 & 0.38 \\
\hline Renewables & n/a & 1.41 & 1.41 \\
\hline Total & $n / a$ & 6.19 & 5.94 \\
\hline \multicolumn{4}{|c|}{ Space Cooling } \\
\hline Electric & $n / a$ & 0.52 & 0.50 \\
\hline Renowables & $n / a$ & 0.00 & 0.00 \\
\hline \multicolumn{4}{|c|}{ Thormal } \\
\hline Liquid Fuels & $n / a$ & 0.03 & 0.03 \\
\hline Gas & $n / a$ & 1.77 & 1.76 \\
\hline Electric & $n / a$ & 0.70 & 0.61 \\
\hline Renewable & $n / a$ & 0.00 & 0.00 \\
\hline Total & $n / a$ & 2.50 & 2.41 \\
\hline \multicolumn{4}{|c|}{ Lights/Appliances } \\
\hline Refrigerator & $n / a$ & 0.56 & 0.54 \\
\hline Lighting & $n / a$ & 0.33 & 0.33 \\
\hline Other & $n / a$ & 0.95 & 0.95 \\
\hline \multicolumn{4}{|c|}{ Total } \\
\hline Liquid Fuols & 1.27 & 1.13 & 1.08 \\
\hline Gas & 4.52 & 5.07 & 4.90 \\
\hline Coal Solids & 0.06 & 0.12 & 0.11 \\
\hline Electric & 3.15 & 3.49 & 3.32 \\
\hline Renewables & 0.83 & 1.48 & 1.48 \\
\hline Total & 9.83 & 11.28 & 10.89 \\
\hline
\end{tabular}

Note: Totals may not equal sum of components due to independent rounding. 
Table D19. Commerclal End-Use Energy Consumption (Quadrillion Btu)

\begin{tabular}{|c|c|c|c|}
\hline & 1990 & $\begin{array}{c}2000 \\
\text { Administration } \\
\text { Baseline }\end{array}$ & $\begin{array}{c}2000 \\
\text { Comblined } \\
\text { Polley Case }\end{array}$ \\
\hline \multicolumn{4}{|c|}{ Space Heating } \\
\hline Liquid Fuels & $n / a$ & 0.67 & 0.64 \\
\hline Gas & $n / a$ & 2.17 & 2.12 \\
\hline Coal Solids & $n / a$ & 0.07 & 0.07 \\
\hline Electric & $n / a$ & 0.62 & 0.58 \\
\hline Renewables & $n / a$ & 0.13 & 0.13 \\
\hline Total & $n / \mathbf{a}$ & 3.65 & 3.54 \\
\hline \multicolumn{4}{|c|}{ Space Cooling } \\
\hline Electric & $n / a$ & 0.74 & 0.71 \\
\hline Renewables & $n / a$ & 0.04 & 0.04 \\
\hline \multicolumn{4}{|c|}{ Thermal } \\
\hline Liquid Fuels & $n / a$ & 0.05 & 0.05 \\
\hline Gas & $n / a$ & 0.77 & 0.74 \\
\hline Electric & $n / a$ & 0.12 & 0.10 \\
\hline Renewables & $n / a$ & 0.00 & 0.01 \\
\hline Total & $n / \mathbf{a}$ & 0.94 & 0.90 \\
\hline \multicolumn{4}{|c|}{ Lights/Appllances } \\
\hline Refrigerator & $n / a$ & 0.15 & 0.15 \\
\hline Lighting & $n / a$ & 0.97 & 0.94 \\
\hline Other & $n / a$ & 0.29 & 0.29 \\
\hline \multicolumn{4}{|c|}{ Total } \\
\hline Liquid Fuols & 0.91 & 0.72 & 0.69 \\
\hline Gas & 2.76 & 2.94 & 2.87 \\
\hline Coal Solids & 0.10 & 0.07 & 0.07 \\
\hline Electric & 2.86 & 2.88 & 2.76 \\
\hline Renewables & 0.10 & 0.17 & 0.17 \\
\hline Total & 6.73 & 6.78 & 6.56 \\
\hline
\end{tabular}

Note: Totals may not equal sum of components due to independent rounding. 
Table D20. Industrial End-Use Energy Consumptlon (Quadrillion Btu)

\begin{tabular}{|c|c|c|c|}
\hline & 1990 & $\begin{array}{c}2000 \\
\text { Administration } \\
\text { Baseline }\end{array}$ & $\begin{array}{l}2000 \\
\text { Combined } \\
\text { Policy Case }\end{array}$ \\
\hline \multicolumn{4}{|c|}{ Steam } \\
\hline Liquid Fuels & $n / a$ & 1.95 & 1.80 \\
\hline Gas & $n / a$ & 1.88 & 1.93 \\
\hline Coal Solids & $\mathrm{n} / \mathrm{a}$ & 0.91 & 0.90 \\
\hline Renowables & $n / a$ & 1.49 & 1.46 \\
\hline Total & $\mathrm{n} / \mathrm{a}$ & 6.23 & 6.09 \\
\hline \multicolumn{4}{|c|}{ Other Heat } \\
\hline Liquid Fuels & $\mathrm{n} / \mathrm{a}$ & 2.02 & 1.83 \\
\hline Gas & $n / a$ & 4.05 & 4.10 \\
\hline Coal Solids & $n / a$ & 0.62 & 0.61 \\
\hline Electric & $n / a$ & 0.01 & 0.01 \\
\hline Total & n/a & 6.69 & 6.55 \\
\hline \multicolumn{4}{|c|}{ Foedstocks } \\
\hline Liquid Fuels & $n / a$ & 4.61 & 4.62 \\
\hline Gas & n/a & 1.16 & 1.16 \\
\hline Coal Solids & $n / a$ & 0.97 & 0.98 \\
\hline Total & $n / a$ & 6.74 & 6.75 \\
\hline \multicolumn{4}{|c|}{ Lease/Plant Fuel } \\
\hline Gas & $n / a$ & 1.29 & 1.30 \\
\hline \multicolumn{4}{|c|}{ Machine Drive/Electrolytic } \\
\hline Liquid Fuels & $\mathrm{n} / \mathrm{a}$ & 0.03 & 0.03 \\
\hline Gas & $n / a$ & 0.19 & 0.19 \\
\hline Coal Solids & n/a & 0.03 & 0.03 \\
\hline Electric & $n / a$ & 4.32 & 4.13 \\
\hline Total & n/a & 4.57 & 4.39 \\
\hline \multicolumn{4}{|c|}{ Cogeneration } \\
\hline Liquid Fuols & $n / a$ & 0.16 & 0.15 \\
\hline Gas & $\mathrm{n} / \mathrm{a}$ & 1.65 & 1.65 \\
\hline Coal Solids & $n / a$ & 0.13 & 0.13 \\
\hline Biomass & $n / a$ & 0.72 & 0.70 \\
\hline Total & n/e & 2.66 & 2.63 \\
\hline \multicolumn{4}{|c|}{ Industrial Cogeneration } \\
\hline Electric & $n / a$ & -0.61 & -0.61 \\
\hline \multicolumn{4}{|c|}{ Total } \\
\hline Liquid Fuels & 8.31 & 8.70 & 8.29 \\
\hline Gas & 8.47 & 10.23 & 10.32 \\
\hline Coal Solids & 2.75 & 2.66 & 2.65 \\
\hline Eloctric & 3.23 & 3.72 & 3.53 \\
\hline Renewables & 2.07 & 2.22 & 2.16 \\
\hline Total & 24.84 & 27.52 & 26.80 \\
\hline
\end{tabular}

Note: Totals may not equal sum of components due to independent rounding. 
Table D21. Transportation Sector Energy Consumption (Quadrillion Btu)

\begin{tabular}{|c|c|c|c|}
\hline & 1990 & $\begin{array}{c}2000 \\
\text { Adminiatration } \\
\text { Baselino }\end{array}$ & $\begin{array}{l}2000 \\
\text { Combinod } \\
\text { Policy Case }\end{array}$ \\
\hline \multicolumn{4}{|c|}{ Energy Use by Mode } \\
\hline Total & 22.50 & 25.67 & 25.33 \\
\hline Light-Duty Vohicles & 13.14 & 15.18 & 14.87 \\
\hline Heary-Duty Vehicles & 3.32 & 3.38 & 3.35 \\
\hline Air Travel & 3.20 & 3.74 & 3.74 \\
\hline Railroads & 0.49 & 0.51 & 0.51 \\
\hline Waterborne & 1.39 & 1.92 & 1.92 \\
\hline Pipeline & 0.68 & 0.75 & 0.75 \\
\hline Other & 0.17 & 0.19 & 0.19 \\
\hline \multicolumn{4}{|c|}{ Percent Shares } \\
\hline Light-Duty Vehicles & 58.40 & 59.14 & 58.71 \\
\hline Heavy-Duty Vehicles & 15.24 & 13.15 & 13.22 \\
\hline Air Travel & 14.22 & 14.58 & 14.78 \\
\hline Railroads & 2.18 & 2.00 & 2.02 \\
\hline Waterborne & 6.18 & 7.48 & 7.56 \\
\hline Pipeline & 3.02 & 2.91 & 2.95 \\
\hline Other & 1.07 & 0.74 & 0.75 \\
\hline \multicolumn{4}{|c|}{ Energy Use by Type } \\
\hline Total & 22.50 & 25.67 & 25.33 \\
\hline Oil & 21.80 & 24.73 & 24.36 \\
\hline Motor Gasoline & 13.58 & 15.48 & 15.16 \\
\hline Diesel & 3.83 & 4.27 & 4.23 \\
\hline Jet Fuel & 3.13 & 3.59 & 3.59 \\
\hline Residual & 1.02 & 1.23 & 1.23 \\
\hline Other & 0.24 & 0.15 & 0.15 \\
\hline Mothanol & 0.00 & 0.02 & 0.02 \\
\hline Ethanol & 0.00 & 0.00 & 0.00 \\
\hline Natural Gas & 0.68 & 0.78 & 0.81 \\
\hline Electricity & 0.01 & 0.14 & 0.14 \\
\hline \multicolumn{4}{|c|}{ Percent Shares } \\
\hline Oil & 96.9 & 96.3 & 96.2 \\
\hline Alcohol & 0.0 & 0.1 & 0.1 \\
\hline Natural Gas & 3.0 & 3.1 & 3.2 \\
\hline Electricity & 0.0 & 0.5 & 0.5 \\
\hline
\end{tabular}

Note: Totals may not equal sum of components due to independent rounding. 
Table D22. Llght-Duty Vehlcle Energy Consumption

\begin{tabular}{|c|c|c|c|}
\hline & 1990 & $\begin{array}{c}2000 \\
\begin{array}{c}\text { Administration } \\
\text { Baselino }\end{array}\end{array}$ & $\begin{array}{c}2000 \\
\text { Combined } \\
\text { Policy Case }\end{array}$ \\
\hline Vehicle Milles Travoled (billion) & 2,030 & 2,515 & 2,470 \\
\hline Fuel Consumption (quadrillion Btu) & 13.14 & 15.18 & 14.87 \\
\hline Motor Gasoline & 12.84 & 14.62 & 14.31 \\
\hline Diesel & 0.30 & 0.50 & 0.49 \\
\hline Mothanol & 0.00 & 0.00 & 0.00 \\
\hline Ethanol & 0.00 & 0.00 & 0.00 \\
\hline Natural Gas & 0.00 & 0.03 & 0.05 \\
\hline Electricity & 0.00 & 0.03 & 0.03 \\
\hline Vohicle Stock (million) & 169.8 & 201.8 & 201.5 \\
\hline Autos & 120.6 & 133.0 & 133.0 \\
\hline Light-Duty Trucks & 49.3 & 68.8 & 68.5 \\
\hline Vehicle Sales (million) & 12.5 & 16.6 & 16.6 \\
\hline Autos & 8.7 & 10.8 & 10.8 \\
\hline Light-Duty Trucks & 3.8 & 5.8 & 5.8 \\
\hline \multicolumn{4}{|c|}{ EPA Eatimated Efficlency, All Fuels (miloe per gallon) } \\
\hline Now Cars & 27.7 & 30.0 & 30.1 \\
\hline Now Light-Duty Trucks & 21.3 & 24.4 & 24.4 \\
\hline Floet Average & 23.4 & 26.1 & 26.2 \\
\hline Car Fleot Average & 25.0 & 28.7 & 28.8 \\
\hline Light-Duty Truck Fleet Average & 20.7 & 23.1 & 23.1 \\
\hline \multicolumn{4}{|c|}{ On-Road Fuel Efficlency, All Fuels (miles per gallon) } \\
\hline New Cars & 23.5 & 25.3 & 25.4 \\
\hline Now Light-Duty Trucks & 16.1 & 18.3 & 18.4 \\
\hline Fleot Average & 19.4 & 20.7 & 20.8 \\
\hline Car Fleet Average & 21.2 & 23.4 & 23.4 \\
\hline Light-Duty Truck Fleet Average & 15.6 & 16.8 & 16.8 \\
\hline \multicolumn{4}{|c|}{ EPA Estimated Efficlency, Gasolline/Dlesel (miles per gallon) } \\
\hline Now Cars & 27.7 & 29.9 & 30.0 \\
\hline New Light-Duty Trucks & 21.3 & 24.3 & 24.4 \\
\hline Fleet Average & 23.4 & 26.1 & 26.2 \\
\hline Car Fleat Average & 25.0 & 28.7 & 28.7 \\
\hline Light-Duty Truck Fleot Average & 20.7 & 23.1 & 23.1 \\
\hline \multicolumn{4}{|c|}{ On-Road Efficiency, Gasoline/Diesel (miles per gallon) } \\
\hline Now Cars & 23.5 & 25.3 & 25.4 \\
\hline Now Light-Duty Trucks & 16.1 & 18.3 & 18.4 \\
\hline Fleet Average & 19.4 & 20.7 & 20.7 \\
\hline Car Fleet Average & 21.2 & 23.4 & 23.4 \\
\hline Light-Duty Truck Fleot Average & 15.6 & 16.8 & 16.8 \\
\hline \multicolumn{4}{|c|}{ Percent of Light-Duty Vohicle Saloe } \\
\hline Gasoline lce & 100.0 & 95.2 & 95.2 \\
\hline Alcohol-Flox & 0.0 & 2.2 & 2.2 \\
\hline Alcohol-Dedicated & 0.0 & 0.0 & 0.0 \\
\hline Compressed Natural Gas lce & 0.0 & 1.1 & 1.1 \\
\hline Electric & 0.0 & 1.5 & 1.5 \\
\hline Electric Hybrid & 0.0 & 0.0 & 0.0 \\
\hline Advanced & 0.0 & 0.0 & 0.0 \\
\hline
\end{tabular}

Note: Totals may not equal sum of components due to independent rounding. 
Table D23. Heavy-Duty Vehlcle Energy Consumption

\begin{tabular}{|c|c|c|c|}
\hline & 1990 & $\begin{array}{c}2000 \\
\begin{array}{c}\text { Administration } \\
\text { Baseline }\end{array}\end{array}$ & $\begin{array}{c}2000 \\
\text { Combined } \\
\text { Policy Case }\end{array}$ \\
\hline Vohiclo Miles Travoled (billion) & 138 & 177 & 177 \\
\hline Fuel Consumption (quadrillion Btu) & 3.32 & 3.38 & 3.35 \\
\hline Diesel & 2.68 & 2.77 & 2.73 \\
\hline Motor Gasoline & 0.64 & 0.53 & 0.52 \\
\hline Mothanol & 0.00 & 0.02 & 0.02 \\
\hline Ethanol & 0.00 & 0.00 & 0.00 \\
\hline Natural Gas & 0.00 & 0.06 & 0.07 \\
\hline Vehicle Stock (million) & 4.4 & 5.1 & 5.1 \\
\hline Light-Heavy & 1.0 & 1.0 & 1.0 \\
\hline Medium-Heavy & 1.8 & 2.1 & 2.1 \\
\hline Heavy-Heavy & 1.0 & 1.4 & 1.4 \\
\hline Buses & 0.6 & 0.7 & 0.7 \\
\hline Vohiclo Salos (million) & 461 & 580 & 580 \\
\hline Light-Heavy & 79 & 88 & 88 \\
\hline Medium-Heavy & 173 & 218 & 218 \\
\hline Heavy-Heavy & 161 & 216 & 216 \\
\hline Buses & 48 & 57 & 57 \\
\hline \multicolumn{4}{|l|}{ Efficioncy (miles per gallon) } \\
\hline New Light-Heavy & 12.7 & 14.1 & 14.1 \\
\hline Now Modium-Hoavy & 8.8 & 9.7 & 9.7 \\
\hline Now Heavy-Heavy & 6.4 & 7.1 & 7.1 \\
\hline Now Buses & 7.8 & 8.5 & 8.5 \\
\hline Fleet Average Fuel Efficiency (miles per gallon) & 5.9 & 7.3 & 7.3 \\
\hline Light-Heavy Fleot Average & 9.3 & 12.0 & 12.1 \\
\hline Medium-Heavy Fleet Average & 6.7 & 8.5 & 8.5 \\
\hline Heavy-Heavy Fleot Average & 5.4 & 6.4 & 6.5 \\
\hline Bus Fleet Average & 6.4 & 7.4 & 7.4 \\
\hline
\end{tabular}

Note: Totals may not equal sum of components due to independent rounding. 
Table D24. Air, Rallroad, and Other Energy Consumption

\begin{tabular}{|c|c|c|c|}
\hline & 1990 & $\begin{array}{c}2000 \\
\text { Administration } \\
\text { Baseline }\end{array}$ & $\begin{array}{c}2000 \\
\text { Combined } \\
\text { Policy Case }\end{array}$ \\
\hline \multicolumn{4}{|c|}{ Air Travel } \\
\hline Passenger Revenue Miles (billion) & 340 & 685 & 685 \\
\hline Fuel Efficiency (indexed to 1990) & 1.00 & 1.16 & 1.16 \\
\hline Fuel Consumption (quadrillion Btu) & 3.20 & 3.74 & 3.74 \\
\hline \multicolumn{4}{|c|}{ Railroads } \\
\hline Rail-Freight (ton-miles) & 967 & 1,073 & 1,070 \\
\hline Fuel Efficiency (indexed to 1990) & 1.00 & 1.04 & 1.05 \\
\hline Fuol Consumption (quadrillion Btu) & 0.49 & 0.51 & 0.51 \\
\hline \multicolumn{4}{|c|}{ Other } \\
\hline Waterborne Fuel Consumption (quadrillion Btu) & 1.39 & 1.92 & 1.92 \\
\hline Pipeline Fuel Consumption (quadrillion Btu) & 0.68 & 0.75 & 0.75 \\
\hline Other Modes Fuel Consumption (quadrillion Btu) & 0.17 & 0.19 & 0.19 \\
\hline
\end{tabular}

Note: Totals may not equal sum of components due to independent rounding. 
Table D25. Carbon Emlssions by End-Use Sector and Source (Million Metric Tons)

\begin{tabular}{|c|c|c|c|}
\hline & 1990 & $\begin{array}{c}2000 \\
\text { Administration } \\
\text { Baseline }\end{array}$ & $\begin{array}{c}2000 \\
\text { Combined } \\
\text { Policy Case }\end{array}$ \\
\hline \multicolumn{4}{|c|}{ Residential } \\
\hline Potroleum & 24.0 & 23.7 & 22.7 \\
\hline Natural Gas & 65.0 & 73.7 & 71.2 \\
\hline Coal & 1.6 & 2.9 & 2.8 \\
\hline Renowables & 0.0 & 0.0 & 0.0 \\
\hline Total & 90.6 & 100.3 & 96.8 \\
\hline \multicolumn{4}{|c|}{ Commercial } \\
\hline Petroloum & 18.1 & 15.1 & 14.5 \\
\hline Natural Gas & 38.7 & 42.8 & 41.7 \\
\hline Coal & 2.3 & 1.8 & 1.7 \\
\hline Renewables & 0.0 & 0.0 & 0.0 \\
\hline Total & 59.2 & 59.6 & 57.8 \\
\hline \multicolumn{4}{|c|}{ Industrial } \\
\hline Petroloum & 91.9 & 85.7 & 77.2 \\
\hline Natural Gas & 119.6 & 131.8 & 133.2 \\
\hline Coal & .67 .8 & 67.5 & 67.1 \\
\hline Renewables & 0.0 & 0.0 & 0.0 \\
\hline Total & 279.3 & 285.0 & 277.6 \\
\hline \multicolumn{4}{|c|}{ Transportation } \\
\hline Petroleum & 422.3 & 485.0 & 477.9 \\
\hline Natural Gas & 9.9 & 11.4 & 11.8 \\
\hline Coal & 0.0 & 0.0 & 0.0 \\
\hline Alcohol Fuels & 0.0 & 0.0 & 0.0 \\
\hline Total & 432.2 & 496.4 & 489.7 \\
\hline \multicolumn{4}{|c|}{ Eleciric Utilities } \\
\hline Petroleum & 26.8 & 26.8 & 26.7 \\
\hline Natural Gas & 41.2 & 55.3 & 57.9 \\
\hline Coal & 408.8 & 420.0 & 371.0 \\
\hline Renowables & 0.0 & 0.0 & 0.0 \\
\hline Total & 476.7 & 502.1 & 455.6 \\
\hline \multicolumn{4}{|c|}{ Primary Energy } \\
\hline Petroleum & 583.2 & 637.0 & 619.7 \\
\hline Natural Gas & 274.4 & 315.0 & 315.8 \\
\hline Coal & 480.4 & 492.8 & 443.3 \\
\hline Renewables & 0.0 & 0.0 & 0.0 \\
\hline Alcohols & 0.0 & 0.0 & 0.0 \\
\hline Total & $1,338.0$ & $1,444.8$ & $1,378.8$ \\
\hline
\end{tabular}

Note: Totals may not equal sum of components due to independent rounding. 


\section{Appendix E. An Overview of the Ideas Model}

\section{Introduction}

The Integrated Dynamic Energy Analysis Simulation (IDEAS) model (an updated and extended version of the earlier FOSSIL2 model) is a model of U.S. energy supply and demand designed to project the long-term behavior of the U.S. energy system. The model provides detailed projections of U.S. energy supply, demand, prices, costs and emissions over a time horizon of up to 40 years, and has the ability to test a wide variety of alternative energy policy options.

The first part of this appendix discusses the model methodology. The second part contains brief descriptions of the major sectors of the model. A somewhat more detailed description of the model can be found in $A n$ Overview of the Ideas Model, 1993

\section{Model Methodology}

\section{Outputs}

IDEAS reports many different variables that can be used as yardsticks to gauge the success or failure of energy policies. The model does not contain one overall measure of social welfare - the policymaker has the flexibility of weighing the impacts that different policies have on multiple outputs in order to arrive at a sensible energy strategy. If a particular policy initiative is aimed at global warming, for example, then reductions in greenhouse gas emissions will weigh more heavily than reductions in oil use. The outputs of most interest to policy planners are energy use, the cost of energy services, and emissions.

\section{Energy Use}

Changes in fuel use are one of the most common measures of policy impact and can serve a variety of purposes. Increasing national energy security, reducing the balance of payments, moving towards a sustainable energy future, and reducing greenhouse gas emissions are just a few examples of desirable policy goals that call for changes in the mix of fuels used domestically. Fuel use is broken down by sector (residential, commercial, industrial, transportation), by end-use (space heating, appliances, lighting, light-duty vehicles, etc.) and by fuel type. Conversion processes such as electricity production also break out fuel use by fuel type. Policies that affect fuel use in one end-use sector can have secondary effects in other unrelated sectors if the fuel price is sensitive to the overall level of demand.

\section{Cost of Energy Sorvices}

Changes in the cost of energy services (which includes an end-use device's capital cost, fuel cost, operating and maintenance cost, and conservation measure cost) are one measure of the cost-effectiveness of policies. This measure is more inclusive than energy prices alone, since it includes the cost of consumer investments in energy services in addition to investments by energy suppliers. It is especially useful for evaluating policies that encourage the adoption of energy conservation measures since it will accurately reflect the tradeoff between the investment cost of the conservation measures and the fuel savings that result from their implementation.

\section{Emissions}

IDEAS computes total energy-related emissions of $\mathrm{SO}_{2}, \mathrm{NO}_{\mathrm{x}}, \mathrm{CO}_{2}$, and methane. These outputs are used to evaluate the impact of energy policies on air quality and greenhouse gas emissions. IDEAS provides a consistent framework for evaluating the effect of many different types of policies, such as tax incentives, appliance standards, and technology subsidies or R\&D on greenhouse gas reductions.

\section{Energy Markets}

The IDEAS model has mechanisms that simulate the behavior of energy markets - they adjust eneigy prices to ensure that supply equals demand for certain energy fuels. Only rarely does a situation occur in which 
Figure E1. Market-Clearing Mechanisms in The IDEAs Model

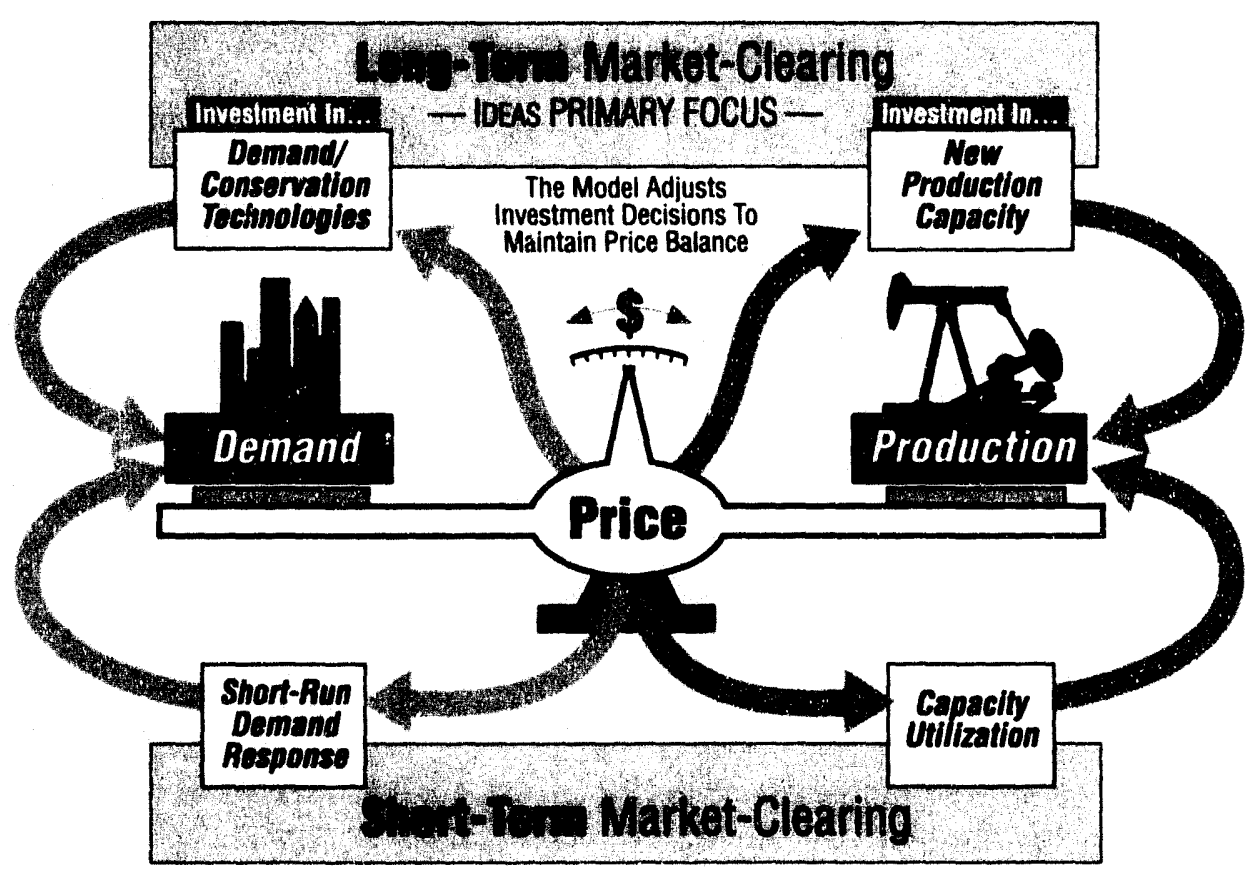

demand is unmet (such as during an oil embargo). The model simulates price-setting and market-clearing mechanisms for the four major energy commodities: oil, natural gas, coal, and electricity. All other prices used in the model (e.g. the price of new capital) are set exogenously by the user.

The following discussion shows how the model's generic market-clearing structure is consistent with economic theory. It should be noted, however, that two of the four model sectors determine price in a non-generic manner: crude oil prices are set exogenously to this model (because oil prices are determined in a world oil market) and electricity prices are regulated (that is, prices are based on costs plus a return on "rate base").

Like most other models of U.S. energy supply and demand, ${ }^{35}$ IDEAS might be described as a partial equilibrium model, because it models the market-equilibrating processes of only a part of the total economy (the energy sector part). ${ }^{36}$ Market-clearing in the IDEAS model occurs over two different time frames, consistent with economic theory: short-run and long-run (see Figure 1) ${ }^{37}$. The explicit representation of short- and longrun market-clearing in IDEAS is an innovative way to translate economic theory into practical application in a descriptive simulation model.

Over the long run, the IDEAS model seek 3 to balance demand and production by investing (or not investing) in new energy supply and demand technologies. ' $n$ imbalance between demand and production capacity causes price to adjust upwards or downwards relat ve to costs. For example, below-normal production capacity (as measured by an industry's capacity factor compared to the long-run industry norm) would cause prices to increase. Higher prices would raise profits, resulting in more investment in new energy production capac-

35. For example, EIA's energy models, the DRI model, GEMINI, or the GRI model.

36. However, because IDEAS captures some of the feedback relationships between the energy sector and the economy, it has some "general equilibrium" properties.

37. See, for example, Edwin Mansfield, Microeconomics: Theory and Applications, New York: W.W. Norton \& Co., 1970, p. 222 ff. 
ity on the supply side. Higher prices also would stimulate more investments in energy-conserving technologies on the demand side. These responses tend to balance energy supply and demand over the long-run after some time lag, the investments add to supply and reduce demand, offsetting the initial price movement (which in this case was a price increase). This response of energy capital investments to prices with the goal of balancing supply and demand over the long term is how the model represents the economic concept of long-run market equilibrium. The behavior of energy supply and demand in pursuit of the goal of long-run equilibrium is what in large part explains the model's energy forecasts.

In addition, the IDEAS model contains structures that represent short-term market-clearing mechanisms. These mechanisms adjust a commodity's supply, demand, and price over a shorter time period (less than one year) to insure that a short-run equilibrium is maintained. In the short-run, energy-using capital stocks and production capacity are fixed. Demand and supply can only be adjusted by changing the intensity of use of these capital stocks. On the demand side, an example of such an adjustment included in the model would be adjusting the thermostat setting for heating and cooling. For supply, the primary short-term adjustment would be changes in capacity utilization - which adjusts upward or downward to match production with short-term demand. Price is set as a function of the balance between demand and production capacity (supply). If supply and demand are balanced, prices are set at a level that will result in a normal return on investment for that industry. This price function (price as a function of supply and demand) is derived from historical behavior in each energy sector.

Economic theory also recognizes that "disequilibrium, rather than equilibrium, has to be the usual state of most real-life markets". 38 The IDEAS model is a dynamic model of energy supply and demand. Dynamic models indicate the movement over a period of time of economic variables and the way such variables move from one equilibrium (or disequilibrium) to another. ${ }^{39}$ For example, the cobweb theorem in economic theory is a simple dynamic model that explains how a commodity's price and output might adjust over time toward equilibrium. Technically, the IDEAS model is a very complex cobweb model ${ }^{40}$. It is a nonlinear dynamic simulation model whose structure is designed to explicitly represent the dynamic behavior of U.S. energy supply and demand.

\section{Energy Demand Sector Methodology}

In the demand sector of IDEAS, U.S. energy demand is represented using a least-cost analytical principle. ${ }^{41} \mathrm{~A}$ benchmarking process is used to reconcile any discrepancy between historical energy demand patterns and least cost projections. Following this approach, the model first projects the demand for energy services (heat, light, steam, shaft power) and then calculates the share of specific end-use markets captured by end-use technologies, including, for example, conservation, cogeneration, or conventional energy-using technologies.

\section{Demand for Energy Services}

Energy services are basically a function of economic activity. People need heat and lighting in houses and offices, manufacturers require steam and shaft power to produce goods, and both goods and people require mobility. In the IDEAS model, the demand for energy services is projected from macroeconomic forecasts of housing, commercial floorspace, and an industrial production index. These components of economic activity are fundamentally linked through a projection of Gross Domestic Product (GDP), but are specified indi-

38. Mansfield, op. cit., p. 240.

39. Mansfield, op. cit., p. 241.

40. The cobweb model does not always converge to equilibrium. Depending upon the slopes of the supply and demand curves the cobweb model can sometimes explode, leading to an ever-increasing gap between quantities demanded and supplied. Convergence to equilibrium has not been formally tested in IDEAS, but in fifteen years of use it has not been known to exhibit behavior typical of an exploding system. It is therefore felt that an equilibrium exists even though it has not yet been formally identified.

41. For a description of the least-cust principle, see A. Lovins, "Energy Strategy: The Road Not Taken," Foreign Affairs 55 (October 1976): 65-96; or R. W. Sant, D. W. Bakke, and R. F. Naill, Creating Abundance: America's Least-Cast Energy Strategy (New York: McGraw-Hill, 1984). 
vidually. In alternate scenarios where GDP projections are modified (either exogenously as in a high or low growth scenario or endogenously in a high or low energy price scenario), the components of activity are internally adjusted as well through an elasticity structure that relates the change in GDP from the base case to a change in each component ${ }^{42}$.

The demand for energy services is a function of several factors:

Number of households, amount of commercial floorspace, etc.,

Base use in a given reference year,

Changes in saturation rates (e.g. changes in the fraction of residential housing stock that has air conditioning), and

Changes in intensity of use (e.g. changes in thermostat settings for air conditioners).

A change in projected economic activity will result in a proportionate change in projected energy services as the housing stock, commercial floorspace, and other macroeconomic drivers change. Appliance saturation rates are set in the reference case and do not change with alternate scenarios or policies. Short-term priceinduced changes in intensity of use can result in slightly different service demand projections. The behavioral response to these secondary factors is generally smaller than the overall trend in service demands that result from economic activity.

In the buildings sectors, saturation rates for appliances and air conditioning vary through time. The historical trend for increased services in these areas is expected to continue in the future. These saturation rates are set exogenously and do not change with scenarios. The behavioral response of changes in intensity of use can take place when energy bills become a larger or smaller portion of household income. This response, which might include turning up or down the thermostat and turning lights off when leaving the room, is analogous to a short-term price elasticity of demand. Because the response is a function of energy bills rather than energy price, it will also reflect the "bounce back" effect that takes place after conservation investments are made, where consumers take back part of the energy savings from conservation measures in the form of increased comfort.

In the manufacturing sector, product/process change multipliers relate the growth in energy services to the aggregate growth in industrial output. These multipliers represent structural shifts in the composition of industrial output mix, as well as major production changes that result from factors other than energy prices. The historical and projected trends are for declining energy services per unit output for steam and process heat, but rising demand for machine drive/electrolytic services. The behavioral component in industry corresponds to energy management practices that become more strict as energy bills increase and more lax with lower energy bills.

In the transportation sector, personal travel in light duty vehicles is determined endogenously as an econometrically-estimated function of the number of households, disposable income, and the fuel portion of vehicle operating cost. The overall trend is toward increasing vehicle miles traveled (VMT) per household through time. Large energy price increases (which raise operating costs) can lower VMT demand and efficiency improvements (which lower operating costs) can increase VMT demand. Heavy duty vehicle service demand is a function of GDP growth and operating costs. The miscellaneous modes of transportation, such as air travel, rail, and marine also increase with GDP.

42. The real drivers for energy services are households, housing stock, commercial floorspace, industrial output, etc. Econometric forecasting models (such as the DRI Long-Term Model) provide consistent forecasts of these drivers as well as a forecast of GDP. Although GDP does not directly drive energy services, it does "drive the drivers" by providing a consistent relationship between each of the drivers and overall economic growth (as measured by GDP). The relationship between GDP and the macroeconomic drivers is captured using elasticities. We also assume that there is a relationship between energy prices (which are computed endogenously in IDEAS) and GDP and that this relationship can also be captured using elasticities. These connections between energy prices and GDP and between GDP and the macroeconomic drivers simulate, in a simple fashion, the effect of price feedback through the economy for the purposes of policy analysis. 


\section{Conservation Supply Curves}

The IDEAS model uses conservation cost and savings curves to represent the conservation technologies available to energy consumers. The curves allow the inclusion of end-use technology detail in an aggregate form. There are separate curves for each fuel within each end-use in each of the sectors: residential, commercial, industry, light and heavy duty vehicles. The conservation measures are ordered by increasing marginal cost. If energy prices rise, consumers will "move up" the curve by investing in more expensive conservation measures when making new appliance purchases.

The conservation cost and savings curves used in IDEAS have a slightly different format than the ones found in many other models. Since IDEAS explicitly models capital stock turnover, the curves are formulated as though the investment decision is being made by an individual energy consumer. Separate sets of curves are also disaggregated by fuel and end-use combination within a sector, and can not be characterized as aggregate supply curves for the sector. The marginal cost used in the curves is the capital cost of the measures. IDEAS converts energy prices to an equivalent first-cost basis internally for different decision-makers using different discount rates before comparing them to the capital cost of the measures. By performing the calculations in this fashion the same curves can be used to determine both consumers' price-induced investments (using a behavioral discount rate and the retail electricity price) and cost-effective levels of investment for utility DSM programs (using a utility discount rate and the avoided cost of new generation.)

\section{Energy Supply Sector Methodology}

Each of the four energy supply sectors of IDEAS represents the behavior of an industry whose purpose is to satisfy the demand for one of the four major fuels used in the U.S. economy (oil, gas, electricity, and coal). Although the energy products of (and government restrictions on) each industry are different, the four industries share certain common structural properties. Each industry must finance new capital investment, allocate the investment to alternative energy sources, and convert the capital, labor, and resource inputs it purchases into a finished energy product. The following sections describe the generic financing and production structures used in IDEAS.

\section{Energy Financing}

Because capital is the major factor of production in energy industries, the financing decision - the generation and allocation of new funds - is the major determinant of future production levels for each energy supply industry. Figure 2 illustrates the financing structure used in each of the IDEAS production sectors. Industry financing is divided in the diagram between sources and uses of funds. Funds may be generated from internal sources or external sources within IDEAS. Internal funds represent funds from operations - retained earnings (from net income) and noncash charges (depreciation plus depletion plus amortization expenses).

\section{Figure E2. IDEAS Financing Structure}

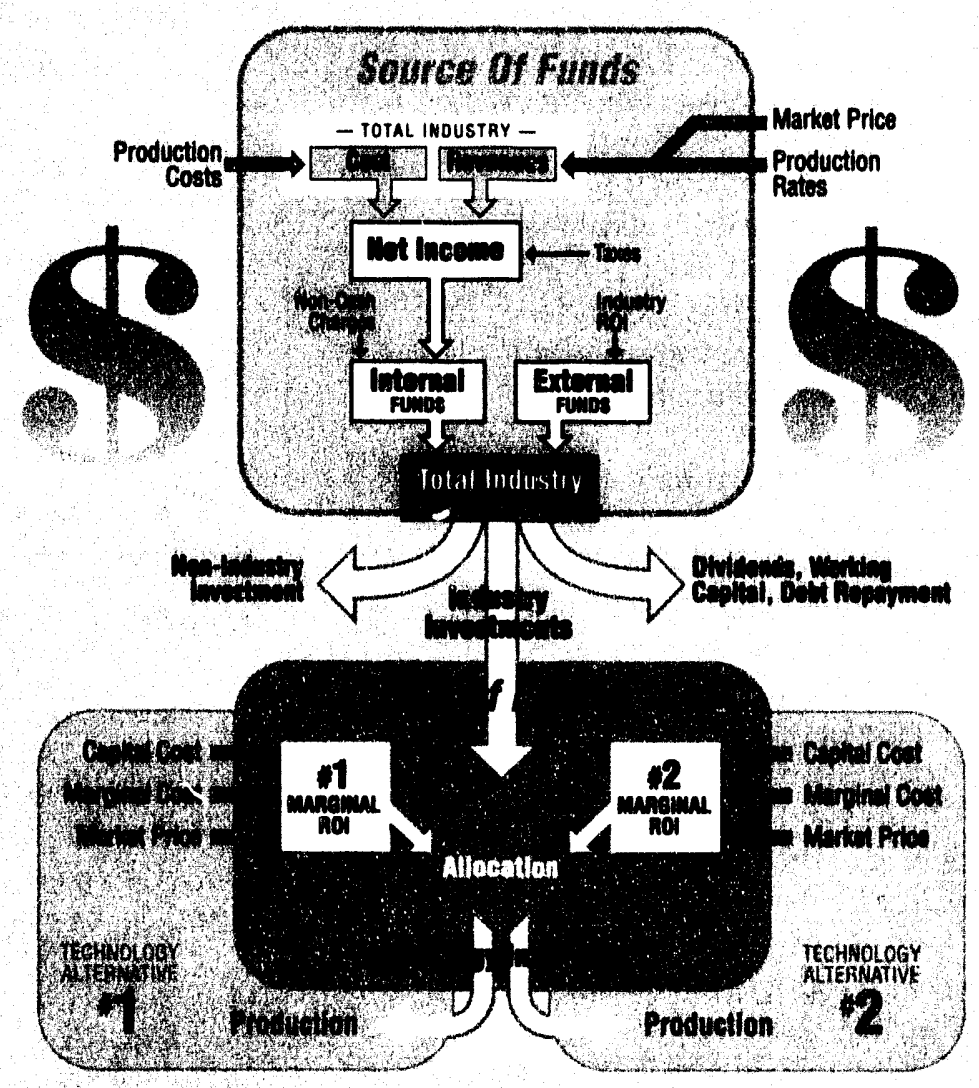


External funds are capital raised by issuing debt or selling equity. Both are calculated endogenously in IDEAS. Net income is a volatile stream of funds that depends on the profitability of current operations. Noncash charges are a steadier source of funds, typically calculated as a fixed percentage of the capital stock.

External financing (through debt and stock issues) can supplement internally generated funds in times of increased financial need. The amount of external financing available is tied to the financial health of the industry, measured by the average industry return on investment (ROI). For example, if the industry has a history of high rates of return, the debt capacity of the industry is expanded. In the case of electric utilities, however, the mix of debt and equity is highly regulated, and therefore is exogenously specified in the model.

The "use of funds" structure in each sector (shown in the bottom half of Figure 2) divides the available capital between various production technology alternatives (the number of these alternatives varies from sector to sector). The allocation function (which uses a probabilistic function) weighs the marginal return on investment (ROI) for each alternative, shifting investment of each as the marginal cost and market price of each production process affects that alternative's marginal ROI. The production process with the highest ROI gets the greatest proportion of capital investment funds. The allocator mechanism therefore tries to maximize future industry profits.

The amount of internal and external investment funds available to an industry is a major determinant of its future ability to expand production. When funds are plentiful, new additions to production capacity can keep in step with growing demand. In the case of the domestic oil industry over the last few decades, for example, the rapid rise in domestic exploration and development costs have decreased the profitability of new oil investment, which has therefore declined. Domestic oil production has consequently been declining since the early $1970 \mathrm{~s}$.

\section{Energy Production Functions}

The production capacity of each of the energy supply options is determined by dynamic production functions in IDEAS. The production functions relate some or all of three factors of production - capital, labor, and resources - to the production capacity of each specific fuel type. Figure 3 illustrates the variety of production functions included in IDEAS. The production functions can be categorized into two types: primary energy production and energy conversion.

The production of primary energy assumes that energy is extracted from a finite and ultimately depletable resource base; this implies that energy production is resourcelimited over the long term. Pro-duction capacity for extraction process$e s$ is therefore a function of resources, physical capital, and (in the case of underground coal) labor availability. In the case of energy conversion technologies (such as electricity), production capacity is controlled by the availability of physical capital (and only indirectly by resources through feedstock availability).

\section{Figure E3. IDEAS Production Functions}

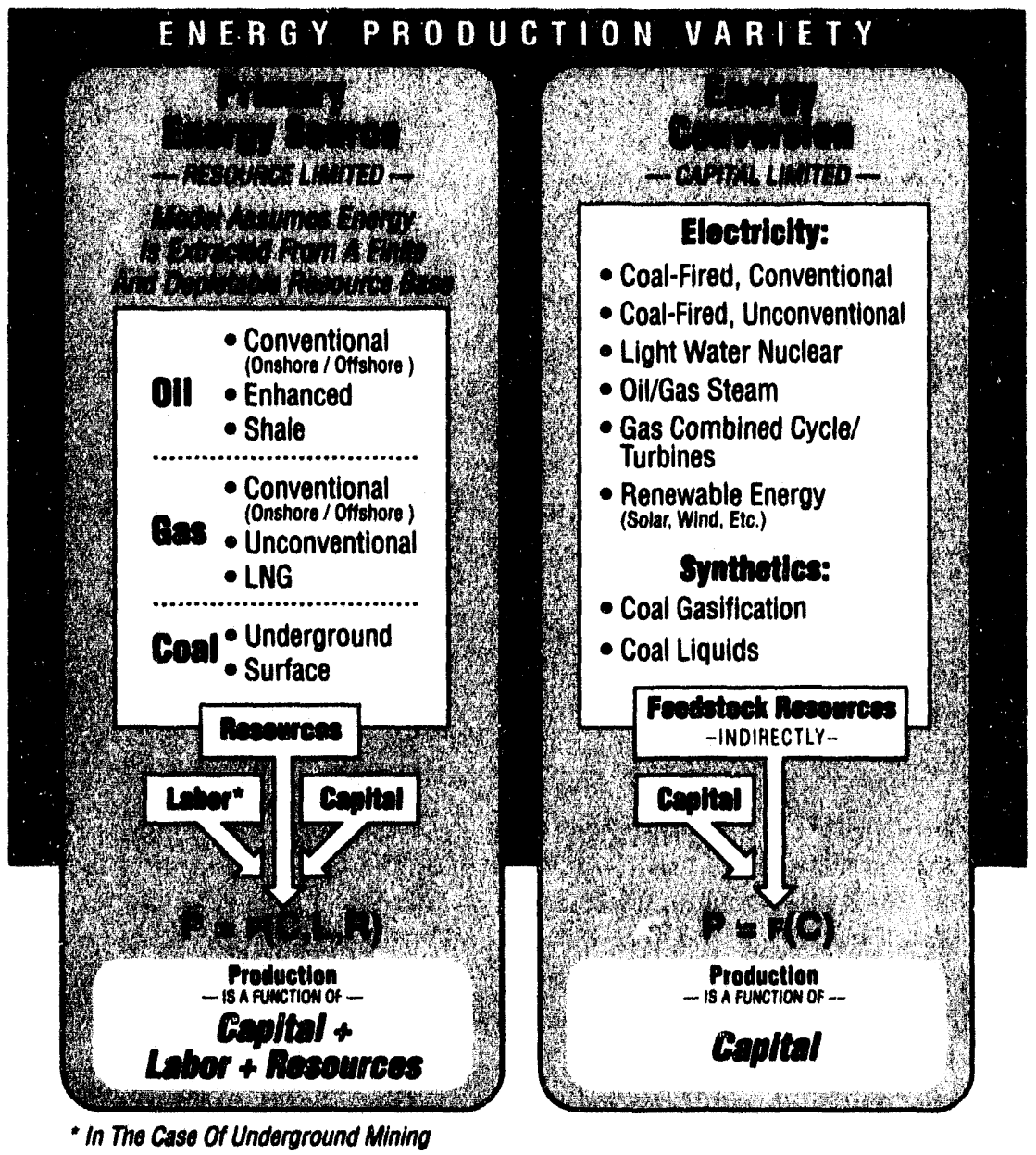


Flgure E4. Conventional OII Production Structure

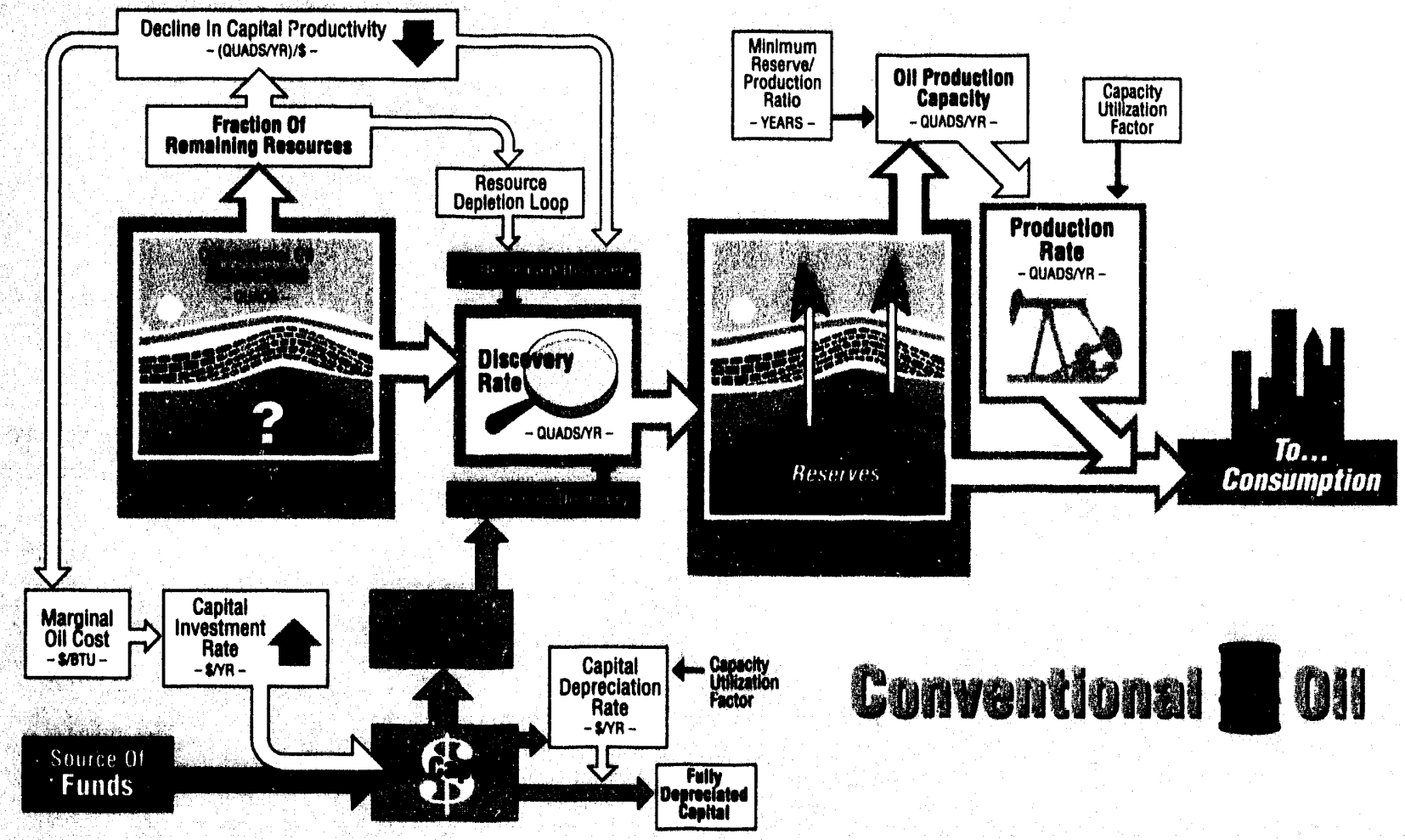

Because of their central importance to the energy transition problem, the dynamics of energy production are modeled in some detail in IDEAS. As an example, Figure 4 illustrates the conventional oil production structure. Tb model the depletion of oil, IDEAS makes the distinction between undiscovered resources and proven reserves. ${ }^{43}$ Resources represent the total inventory of geologic deposits and can only decrease over time, depending on the relative rates of discovery (including new additions, extensions, and revisions) and production. The level of reserves determines the maximum production capacity of conventional oil and gas in IDEAS, for reserves cannot be drained below a minimum reserve/production ratio (typically eight to ten years) because of the limitations of current recovery technologies and reservoir characteristics. The future behavior of oil and gas production will therefore be determined primarily by the rate of discovery of new reserves.

Oil discoveries depend on two factors in IDEAS: capital investments in new drilling activity (for example, drilling rigs) and capital productivity (affected by resource depletion). These factors tend to move oil and gas discoveries in opposite directions: capital accumulation tends to increase discoveries, while resource depletion tends to decrease discoveries through a decline in capital productivity. While the production functions for other sources of energy supply are not as detailed as the conventional ones for oil and gas, they share the same structural dependence on capital, resources, or labor.

\section{Callbration}

The purpose of calibrating the IDEAS model is to provide an acceptable baseline forecast, which can then be used as a starting point for evaluating policies and scenarios. The Office of Policy, Planning and Program

43. Resources are supplies that are hypothesized to exist but that have not been proven to exist through exploratory drilling. Reserves have been demonstrated to exist through the drilling and testing of wells. Unlike the practice for oil and gas, resources and reserves for coal and uranium are aggregated into one stock, since the major cost of production for the latter fuels is incurred in extraction, not in exploration and development. 
Evaluation has determined that the Energy Information Administration's (EIA) Annual Energy Outlook (AEO) should provide the baseline forecast in order to insure consistency within DOE and because it is viewed as a widely credible forecast. In theory, if all assumptions for the models were known and their structures were relatively compatible, two models would produce very similar forecasts. In reality there are always implicit assumptions in models, and data and structures are often not compatible. As a result, the goal of calibration can be better expressed as making IDEAS tell the same story as the AEO.

The first step in the calibration process is to input into the model the most straightforward of the external driving assumptions. These include the world oil price, GDP, other macroeconomic variables, and perhaps oil and gas reserves. For each sector, as much detailed information as possible is taken from the AEO. Some of the remaining assumptions are then modified in such a way as to produce similar fuel projections as the AEO. Other variables, such as conservation technology curves, are considered "hard data" which are not modified in the calibration process. Each of the input assumptions that are adjusted in the calibration process must remain within the reasonable bounds of uncertainty. Calibration therefore entails a careful analysis of the components of energy supply and demand to determine how IDEAS variables explicitly or implicitly correspond to those in the AEO. In addition, a reasonable range of assumptions for those parameters not explicitly specified by EIA must be determined.

\section{Sector Descriptions}

\section{Energy Demand and Conservation}

The IDEAS demand sector is based on the concept that energy consumers act to minimize their energy service costs (not their fuel expenditures). Consumers choose the combination of fuels and end-use technologies that can provide a desired level of energy services (such as comfort, light, or industrial steam) with minimum life-cycle costs. As a part of their decision process, they make a trade-off between normal energy-using equipment and investments in more expensive energy-efficient equipment (such as efficient furnaces, light bulbs, or boilers) which allow lower fuel expenditures. Consumers can also choose among different technology/fuel options (such as a gas furnace versus an electric heat pump).

The demand sector is divided into four major energy-using sectors: residential, commercial, industrial, and transportation. The two buildings sectors are very similar in structure and so will be discussed together. Each of the sectors is further divided into major end-use categories that represent different types of energy service demands.

Figure E5. IDEAS Demand Sector Structure

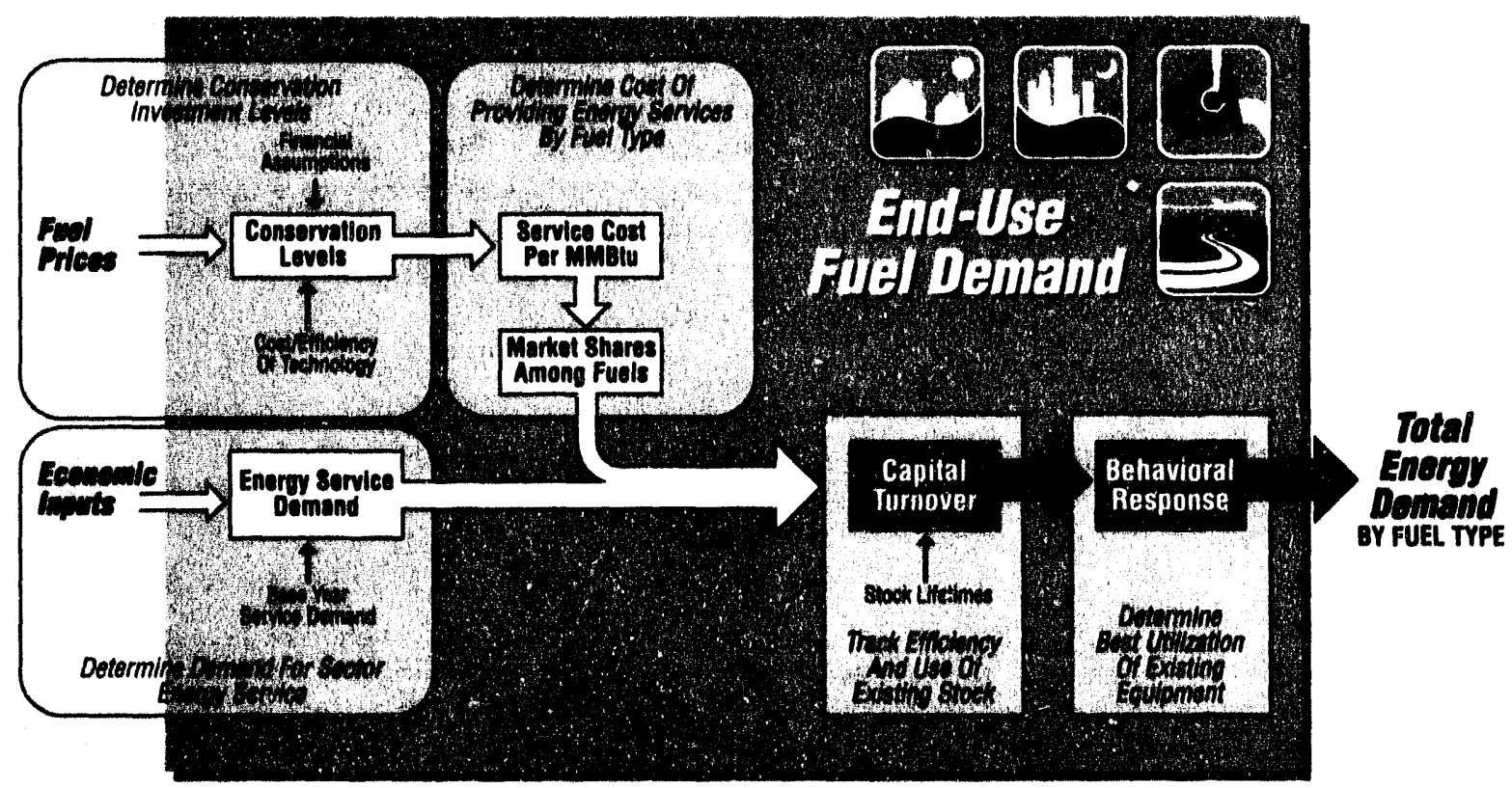




\section{Bulldings}

The residential and commercial sectors are treated separately in the IDEAS model, but are very similar in structure. The same six end-use service categories are defined in each: space heat, cooling, thermal, lighting, refrigeration, and other appliances. The thermal category is a combination of water heating, cooking, and drying. These thermal services provide some type of heat and can be met with a variety of fuels. The other appliances category, on the other hand, represents end-use devices that are electricity-based where no fuel substitution is possible. Due to the aggregate nature of IDEAS, individual building types are not represented separately. The energy service demands represent the aggregate for all residential or commercial buildings.

Figure 5 illustrates the basic structure of the end-use demand sectors in IDEAS. Energy service demand for each end-use category is calculated from the base year service demand and the macroeconomic inputs in each year (projected building stocks and industrial production indices). Conservation investment decisions are made using a least-cost algorithm based on fuel prices, financial assumptions, and the costs and efficiencies of available conservation technologies. Once conservation investment levels are determined, the costs of providing energy services with each appropriate fuel type are calculated and used to determine fuel market shares. A capital turnover or "vintaging" structure keeps track of the efficiency and fuel-use characteristics of all existing stocks as stock is added, retrofitted, and retired. Finally, utilization of existing equipment can be modified through short-term behavioral responses.

The main output from the sectors is total energy use by fuel type, which is used by the various supply sectors. Total energy service costs (the total of capital and energy costs) are also computed as output.

Energy services are projected to increase as a function of the total stock of residential buildings and commercial square feet (but not always in direct proportion). The intensity of some types of services demanded may change through time. For example, more buildings may be constructed with air conditioning, or new appliances or office equipment may be introduced. The demand for new energy services is simply the total need minus the remaining stock from the previous year.

Conservation investments are at the heart of the projection of energy demand and are treated explicitly in the IDEAS model. Conservation technologies are represented in "supply curves" that are specific to each end-use and fuel type (an example of a conservation supply curve is shown in Figure 6). The curves are constructed from data representing technologies currently available, and those anticipated to be available given current data. The conservation supply curves relate the costs and energy savings associated with customers' options for energy efficiency investments in different end-use markets. Policies of accelerated R\&D can be modeled by shifting the curves so that more savings are achieved at each cost level.

The model calculates whether a capital investment in energy efficiency is "worth" the savings in fuel costs it provides, given consumers' different in-

\section{Figure E6. Conservation Supply - New Residential Space Heating -} Capital Cost Of Conservation Technology
PER MILLION BTU's (1989s)

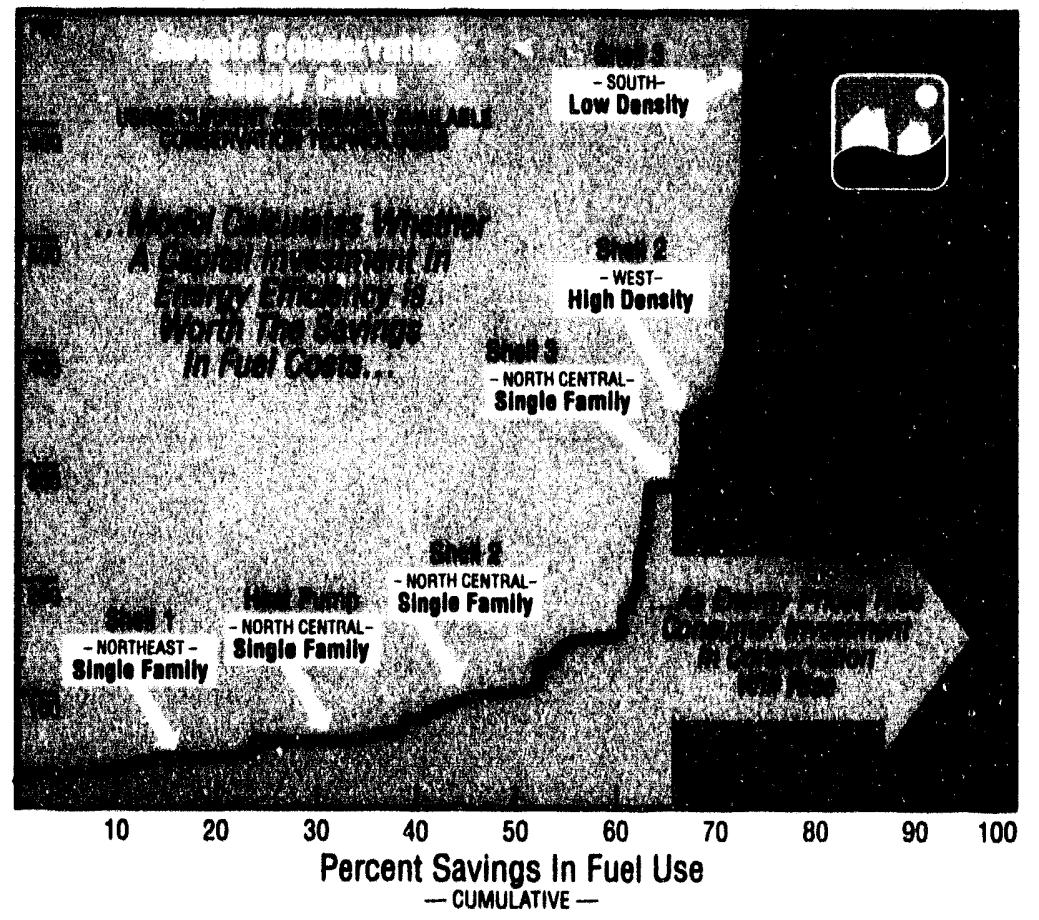


vestment criteria. Consumers are assumed to invest in conservation up to the point where the fuel savings associated with an efficiency choice are worth the additional investment expense. The value of the fuel savings over the lifetime of the measure depends on the hurdle or discount rate used. Historical evidence indicates that consumers make energy investments as if they have a relatively short payback period (two to five years), equivalent to a relatively high hurdle rate. Alternative efficiency cases can be tested by lowering or raising the consumer discount rate.

The conservation technologies are arrayed in least-cost order in the curve, so the cheapest measures are assumed to be implemented first. As energy prices rise, consumers will "move up the curve", investing in higher levels of conservation when making new purchases. For electricity conservation curves, the model contains structure to allow the simulation of electric utility investments in end-use conservation, an important component of utility integrated resource planning. Because utilities generally have lower discount rates than consumers, more conservation will be implemented. The utility is assumed to pay for the added conservation above what the consumer would have done without the utility program, and the consumer pays the same amount as before.

For each end-use service category, the cost of providing energy services with the least-cost combination of equipment and fuel type is calculated. For the end-uses where there is a choice among fuels to satisfy the service, market shares are determined based on the relative energy service costs (see Figure 7). A probabilistic function is used to compute the probability that each fuel-technology option will be less expensive than others (this is different from a strict optimization approach that assumes all consumers face identical costs and determines one cheapest choice that is applied to all new investments). The determination of market shares also takes into consideration any limitations in fuel availability.

After market shares for new energy-using stock are determined, new stock is added to existing stocks, and a new average energy efficiency is created. At the same time, old stock is retired and removed from the total stock. Thus at any time in the future, total energy consumption is a function of the cumulative individual investment decisions made in the past.

Although energy consumption is primarily determined by the energy-using capital stock which changes gradually in response to changes in energy prices, short-term energy usage may be modified. The model includes behavioral responses that change the utilization of existing equipment. For example, during past oil price shocks many consumers simply turned down their thermostats to reduce fuel bills. This type of "conservation" is temporary and has been shown to disappear when prices fall again. The behavioral effect is

Figure E7. Demand Markot Shares Allocation

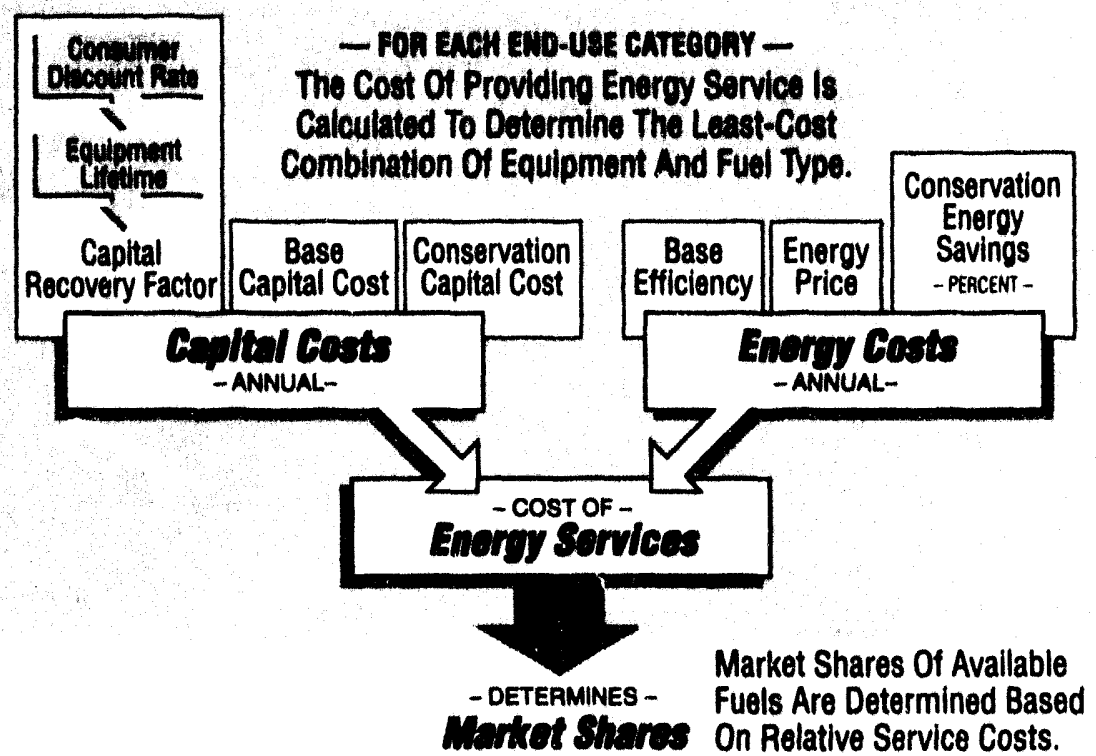

based on the total fuel bill as a fraction of disposable income. This captures the effect that consumers may "take back" part of their conservation savings (decreased fuel expenditures) by increasing their demand for energy services.

After determining energy consumption in each enduse, the model sums the fuels used across all enduses in each sector and adds across all sectors to compute total fuel demand, which is used by the supply sectors to determine new investments in supply and prices. Figure 8 shows the fuels that are included in each end-use cat- 
egory. Dispersed renewables (with the exception of solar) are specified exogenously, but are included as satisfying energy service demands. Therefore any change in projected renewables use will have an impact on the projected conventional fuel use.

\section{Industry}

The structure of the IDEAS industrial sector is similar in many ways to the building sectors. The industrial sector uses the same components of energy service demands, conservation, market shares, capital turnover, and behavioral response that were described in the buildings sector and shown in Figure 5.

Four major end-use categories are represented for industry: steam, process heat, machine drive/electrolytic processes, and feedstocks. Steam technology options include cogeneration technologies as well as conventional boilers. Process heat includes direct and indirect heating used in a variety of industrial processes. Machine drive/electrolytic is an all-electric category representing motors and pumps and electrolysis in the chemicals and aluminum industries. Feedstocks are fuels used for non-energy purposes (such as oil for plastics). These service demands are projected as a function of changes in industrial production. Although individual industries are not explicitly represented in the model, the growth in each service demand is based on the projected mix of industries embodied in total industrial production.

The changing relationship between overall industrial production output growth and energy service demands is represented in product/process change "multipliers"-nonlinear functions which change through time. These multipliers include the effect of the change in industrial mix among industrial (SIC) groups, the change of products within these groups, and the major changes in processes used to make these products. The industrial mix changes will affect the growth in services because some industries are more energy-intensive than others and may change the type of services required (e.g. increasing machine drive while decreasing steam needs). The changes in products can have a similar effect. An example would be the shift in the chemicals industry away from basic chemicals toward more refined products which require fewer energy services to produce. The third type of change, shifts in processes, represents major changes in the way products are made that have implications for energy consumption. For example, the shift from open-hearth furnaces to mini-mills in the steel industry decreased the energy intensity of that industry. The industrial product/process change multipliers are updated to periodically represent new macroeconomic projections and new industrial trends.

As in the buildings sector, conservation curves are used to portray technologies that can reduce energy use in meeting a specific type of industrial service demand. Cogeneration that produces electricity primarily for internal use is treated as an explicit technology choice in the model, rather than as a conservation technology. PURPA qualifying cogeneration that produces electricity expressly for sale to utilities are treated separately in the electricity sector of the model.

After the conservation investments for each energy type and end-use are computed from energy prices and financial para-

Figure E8. Domand Sector - Level Of Aggregation

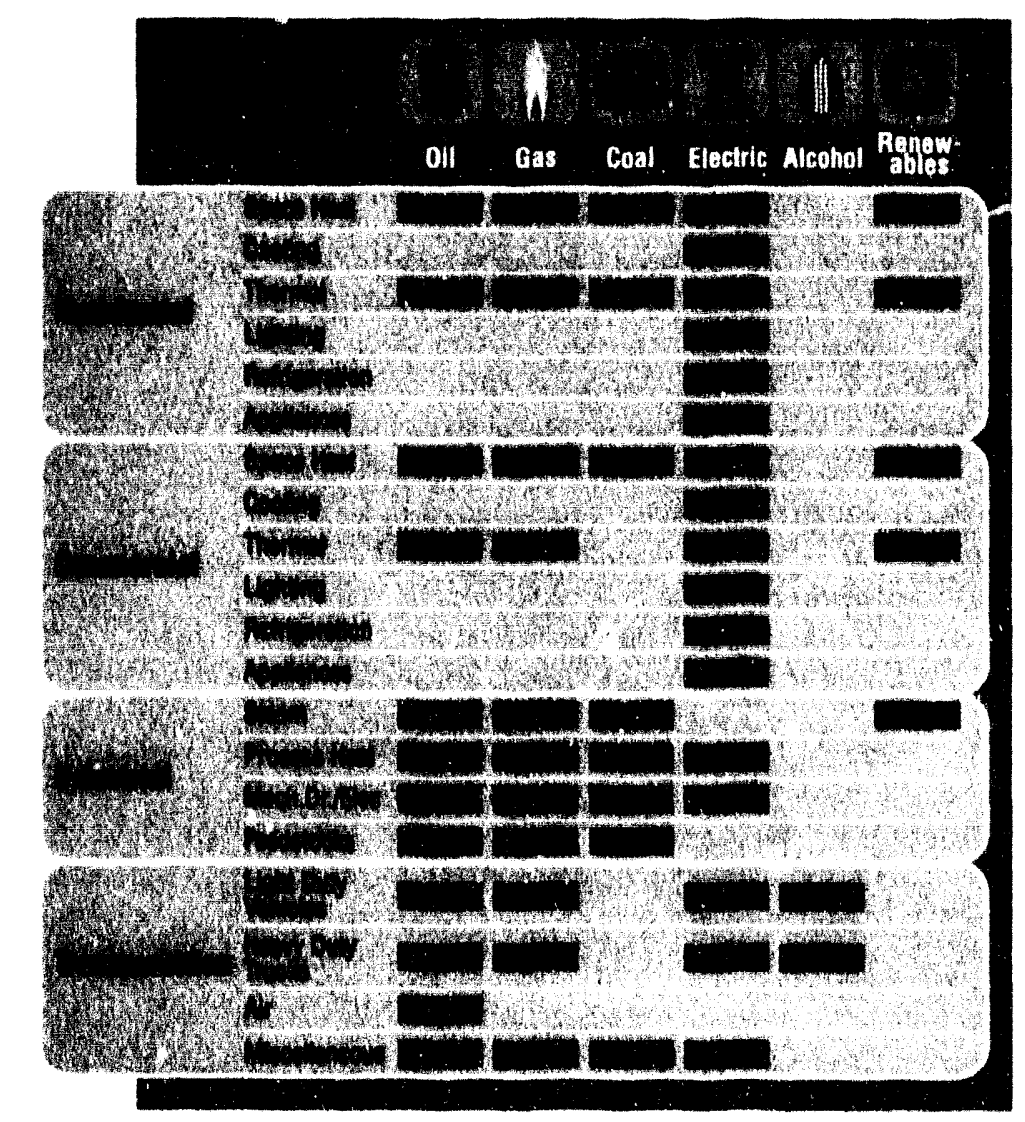


meters, a market share competition is performed among the fuel choices. In the steam sector, boilers and cogeneration systems compete directly. Biomass fuel is included in both, but is limited to only a portion of the industrial market representing the paper and wood products industries that have access to wood as a waste by-product. In process heat, coal has a limited market share since impurities prohibit its use in many direct-heating applications. Machine drive/electrolytic is primarily an electric category with competition only from self-generation. Electricity produced by cogeneration is subtracted from purchased electricity demands. Feedstocks are specified exogenously by fuel type. Figure 8 lists which fuels apply to each service demand category.

Energy-using stocks and their efficiencies are tracked in the model with a vintaging structure, the same way as in the building sectors. There is also a behavioral component to industrial energy demand which represents energy management measures. When energy prices change quickly, industrial managers respond through short-term maintenance measures such as insulating steam pipes, tuning up equipment and the like. These measures cost little to do, can be performed quickly, but are limited in total savings that can be achieved.

\section{Tranaportation}

The transportation sector is comprised of light duty vehicles, heavy duty vehicles, air, marine, rail, and other. Because highway vehicles' energy use comprises over three-quarters of total transportation energy consumption, these sectors are modeled in more detail than the other sectors. Each of the sectors uses fuel price, economic and demographic information generated by the IDEAS model and computes fuel use for the rest of the model.

\section{The Vohicles Sector}

The vehicles sectors include a variety of fuels: gasoline, distillate (diesel) fuel, natural gas, methanol, ethanol, and electricity.

The structure of the light and heavy duty vehicles sector can be divided into six parts. The model endogenously forecasts vehicle sales, the choice between different fueled vehicles, the efficiency of the new vehicle stock, the number of miles vehicles are driven, the specific choice of fuels for multi-fueled vehicles, and the amount of fuel used. Fuel prices affect four types of decisions that consumers make: the number of vehicles of each type to own, the type of fuel to use, the efficiency of the new vehicle, and the number of miles to drive each vehicle. The efficiency submodule combines engineering data with economic calculations to compute long-term and short-term price-induced conservation savings. It keeps track of CAFE standards and computes credits for sales of alternate-fueled vehicles. Outputs from this submodule include final on-road efficiency (miles/MMBTU), final vehicle purchase prices (1975 dollars/vehicle), and performance specifications (horsepower). The efficiencies and fuel prices together determine operating costs (1975 dollars/mile), which are used to predict Vehicle Miles Trovelled (miles/average vehicle) in the VMT subsector. In combination with performance, purchase price and other characteristics, operating costs also help determine the fuel market shares for new vehicles in each vehicle size class in the fuel type choice subsector. Total demand for each size class, computed in the car ownership subsector, is a function of the number of households, household income, and the expected value of characteristics of each size class. New vehicle purchases are added to the existing vehicle stock which is used with the efficiencies and VMT forecasts to compute vehicle fuel use in the vintaging subsector.

\section{The Vintaging Subsector}

The Vintaging subsector integrates data from the other five subsectors. At its simplest it keeps track of the characteristics of the historical vehicle stock and computes fuel use based on these characteristics. Inputs from other model subsectors are the desired vehicle stock from the Car Ownership subsector, market shares of new vehicles by fuel type from the Fuel Type Choice subsector, new vehicle efficiency from the Efficiency/Performance subsector, vehicle miles travelled from the Vehicle Miles Travelled subsector, survival rates from the scrappage subsector, and fuel prices from the IDEAS Pricing sector. The exogenouslyspecified inputs are the initial values for the vehicle stock in the base year (1950), age-specific weights for VMT and efficiency, and fraction of diesel use in petroleum-fueled vehicles. The only important outputs are fuel use, which is used by the IDEAS supply sectors, and fuel cost, which is used by the VMT subsector.

The key interactions are depicted in Figure 9. Age-specific survival rates are computed in the scrappage sub- 
sector and are used to determine the remaining vehicle stock by size class. This is compared with the desired vehicle stock that is computed in the car ownership subsector to produce new vehicle sales by size class. The fuel choice subsector computes fuel type market shares by size class to further disaggregate the new vehicle sales by fuel type within each size class. New vehicle sales by size class and fuel type for each model year are accumulated in the vintaging sector along with the new vehicle efficiencies from the efficiency/performance subsector and user-specified emissions rates.

Fuel use is computed based on the surviving auto stock from each of the previous 30 model years, vehicle miles travelled from the VMT subsector (adjusted for the age of the vehicle), vehicle efficiency for each of the previous 30 model years (also adjusted for the age of the vehicle), and forecasted fuel-specific VMT shares for multi-fuel vehicle types. Emissions are also computed in the same fashion. The allocation of total VMr to each fuel within a multi-fuel vehicle is based on the probability of each fuel having the lowest operating cost nationally.

\section{The Scrappage Subsector}

All inputs to this subsector are user-specified and include the average lifetime of vehicles in each model year and parameters estimated from historically-observed scrappage patterns. The only output, scrappage rates for vehicles, is expressed in terms of the fraction of vehicles of each model year that survive to each later year. For example, 90 percent of the vehicles from a model year may still be on the road 8 years later, but only 50 percent 13 years later and 10 percent 20 years later. New survival rates are computed for each model year based on historically-observed scrappage patterns and are unique to each model year.

\section{The Efficiency/Performance Subsector}

The Efficiency/Performance subsector calculates both market-based (price-induced) and policy-induced adoption of energy conserving technologies. This subsector uses fuel prices generated in other sectors of IDEAS as well as vehicle miles travelled from the VMT subsector. Most of the inputs to this subsector are exogenouslyspecified, are numerous, and fall into two categories. The most important category is data that

Figure E9. Interactions Between The Vintaging Subsector And Othor Subsectors

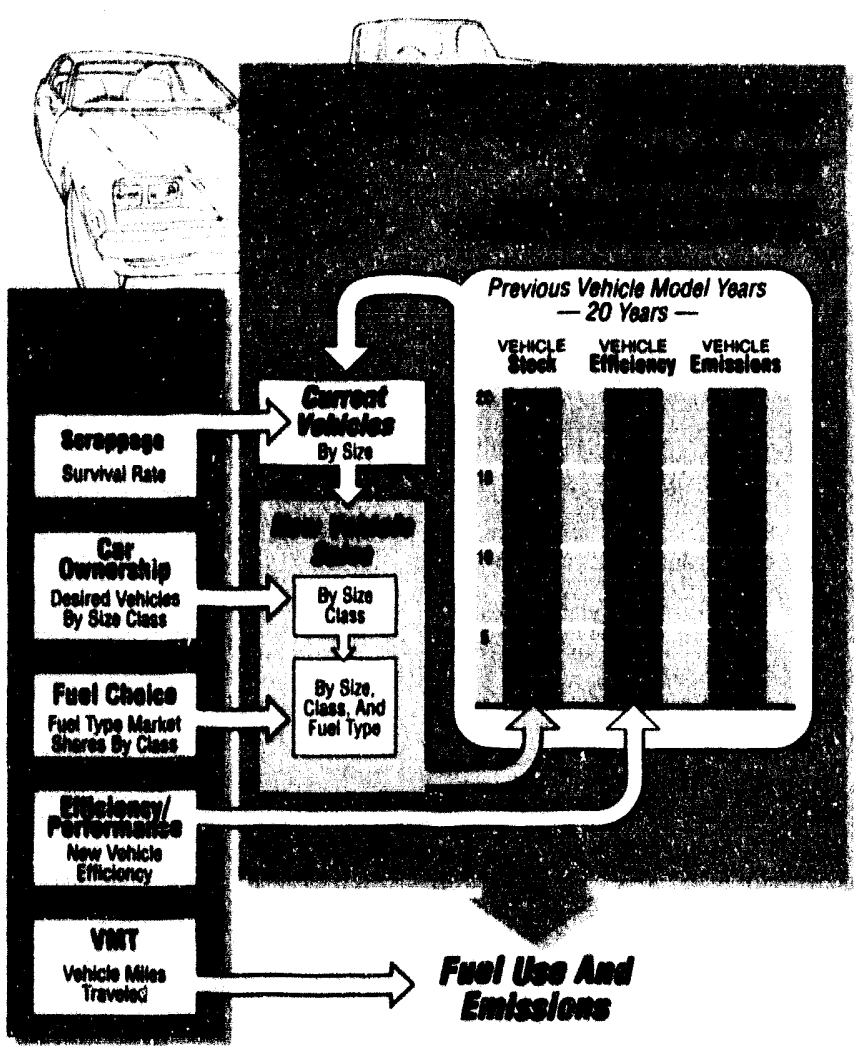
specify the conservation cost curves. These include data that characterize energy-conserving technologies that can be added to vehicles and data that characterize the vehicles themselves. The technologies represent energy-conserving measures that generate savings when they are added to a "base year" vehicle. These curves are represented as continuous functional forms that have been fitted to technology-specific data in a spreadsheet. For the purposes of this model the base year vehicle corresponds to those vehicles sold during the 1990 model year. The parameters that best fit the curves to the data, and 1990 base year vehicle characterization data that describe vehicles that do not yet incorporate the measures, are input to the model.

The second category of data represent the specific policy inputs that characterize the Energy Policy and Conservation Act Mandatory Fuel Economy Performance Standards, also known as the Corporate Automobile Fuel Economy (CAFE) Standards. These data consist of fleetwide fuel efficiency targets for new vehicles, conversion factors to translate estimated efficiency to on-the-road efficiency, penalties and penalty allocation factors for noncompliance, corporate marginal tax rates, and credits for sales of alternate-fueled vehicles. 
This sector produces a new vehicle efficiency, which is used in the vintaging, car ownership, and fuel choice subsectors, and new vehicle purchase prices and performance, which are also used in the car ownership and fuel choice subsectors.

The adoption of energy conserving technologies affects the operating cost of vehicles through changes in vehicle efficiency and the purchase price of vehicles through the cost of adding the technologies to the vehicles. The model assumes that technologies can be applied to more and more models over time. To capture this assumption the model includes different technology cost and savings curve parameters for the years 1995, 2000, 2005, and 2010. It interpolates from no savings in 1990 to the appropriate level of savings in 1995, and it interpolates between the levels of savings available in 1995, 2000, 2005, and 2010. In effect, then, more and more savings become available over the period 1990 - 2010. The model also includes a five-year platform redesign lag between when the measures are selected and when they appear on the market. Furthermore, the cost of adopting a technology through the platform redesign process is high enough that it is assumed that once a technology is incorporated into a vehicle it becomes a permanent part of that vehicle and is not later dropped.

In reality, energy conservation is highly interrelated with vehicle performance. Any energy conservation technology can be used to increase efficiency at the same level of performance, to increase performance at the same level of efficiency, or to increase both performance and efficiency. Furthermore, these trade-offs can be made over a much shorter period of time - one to two years - since platforms do not have to be redesigned to incorporate them, and the cost of changing is low enough that it can be assumed that changes can be both made and unmade fairly easily. The model allows these short-term adjustments to the drivetrain to boost either efficiency or performance in response to market prices or government policy.

The interaction between the longer-term conservation technologies and the shorter-term drivetrain adjustments are shown in Figure 10. Long-term conservation technologies are adopted to the extent that they are either cost-effective or are less expensive than the penalties associated with efficiency standards. The longterm efficiency is relative to a fixed level of performance, however, and both consumers and manufacturers can trade off efficiency with performance over the short term. A relationship between operating cost and performance is derived from consumer choice equations in other parts of the model and is used to predict resulting shifts in performance in response to changes in long-term platform efficiency and fuel prices. The final short-term efficiency shift takes place in response to the shift in performance but is constrained by any efficiency standards that may be in effect.

\section{The Car Ownership Subsector}

The Car Ownership subsector computes desired levels of car ownership by vehicle size class. Data inputs include characteristics of the households from the IDEAS Macroeconomic Sector (number of households and average income of households in two income groups) and characteristics of the vehicles from the Fuel Choice and Efficiency/Performance subsectors (fuel market shares, operating cost,

\section{Figure E10. Relationship Between Long And Short Torm Efficiency}

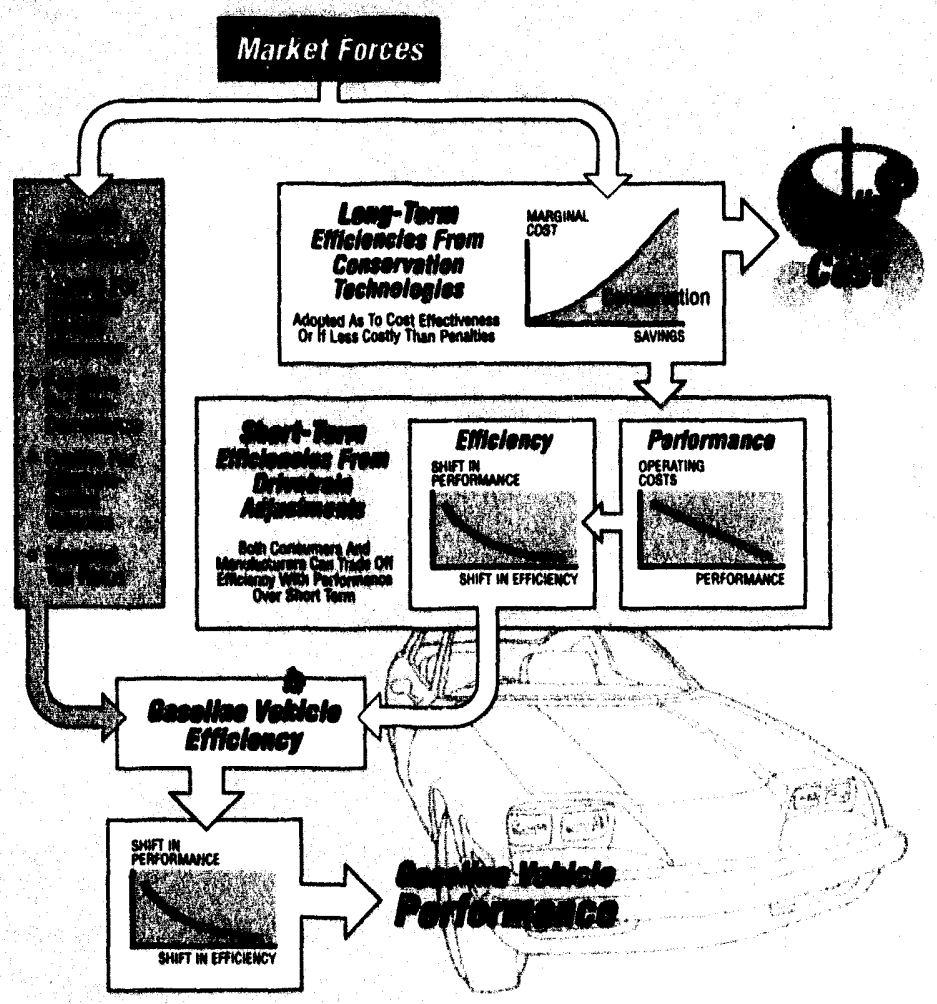


purchase price, and performance), and alternative-specific coefficients for the econometric models of consumer choice that make up this subsector.

The Car Ownership subsector uses a structured multinomial logit model estimated and documented by Ken Train (Train 1986). This model is a two-stage model of level of car ownership $(0,1,2,3+$ vehicles) and size class of vehicle owned (small car, large car, small light duty truck, large light duty truck). The Car Ownership model is composed of four logit models:

1. $P$ (owning $0,1,2$, or $3+$ cars)

2. $P$ (owning a small car, large car, small truck, or large truck l owning 1 car)

3. $P$ (owning two small cars, a small and a large car, etc. l owning 2 cars)

4. $P$ (owning three small cars, two small and a large car, etc l owning $3+$ cars)

The first model can be thought of as the upper level and the other three models can be thought of as the lower level of a model hierarchy because models 2,3 , and 4 are conditional on model 1 . That is, the choice of one small car, one large car, one small truck or one large truck is conditional on having chosen to own one vehicle. The model calculates the expected value of the number of vehicles of each type that a household in each demographic group (low income and high income) would want to own and multiplies these expected values by the number of households in each demographic group to determine the total number of vehicles of each type that are desired.

\section{Fuel Choice Subsector}

The Fuel Choice subsector computes the market share of gasoline and alternate-fueled vehicles in each size class and vehicle type. The operating costs of new vehicles that are computed in this subsector are also used in the Car Ownership subsector. It uses fuel price data from the Pricing sector of IDEAS, and new vehicle efficiencies, performance, and purchase prices from the Efficiency/Performance subsector. Exogenously-specified data are primarily vehicle characteristics such as range, average lifetime, emissions levels, fuel availability, and year of commercial availability. Other exogenously-specified inputs include a statistical parameter that describes the range in variation of fuel prices nationwide, parameters that help control the penetration of alternate-fueled vehicles in the first few years of commercialization, and alternative-specific coefficients for the econometric models of consumer choice that make up this subsector.

The Fuel Choice subsector consists of a set of four multinomial logit models that forecast fuel type choice independently for each vehicle size class (small car, large car, small light duty truck, large light duty truck). These models were estimated and documented by Bunch et. al. (Bunch 1991). Table 4 of this paper presents six equations that were estimated for different vehicle types and size classes, the first four of which are used in this model. These models are used to estimate the new vehicle market shares of the following fuel types: Gasoline/diesel, alcohol flex, dedicated alcohol, compressed natural gas, dedicated electric, electric hybrid, advanced (fuel cell) vehicles.

Each model contains different coefficients for the following vehicle attributes: purchase price, fuel cost, range when fully fueled, emissions relative to current vehicles, fuel availability, performance.

This model can be calibrated to other, more detailed models of fuel choice using the alternative-specific coefficients.

\section{The Vehicle Miles Travelled (VMT) Subsector}

The VMT subsector forecasts annual vehicle miles travelled for vehicles from each model year, vehicle type, size class, and fuel type. Inputs to this subsector include the fuel cost for each type and model year of vehicle from the Vintaging subsector and a user-specified constant for the econometric equation.

The econometric equation used in this subsector is based on one presented in chapter 8 of Ken Train's book Qualitative Choice Analysis (Train 1986). The model has a user-specific coefficient to allow calibration with other models. This equation computes systematic variations in VMT based on changes in the fuel cost of a 
particular vehicle type and treats each model year as though it is new. Age-specific usage factors are later applied to these forecasts when they are used in the Vintaging subsector.

\section{The Alrerait Sector}

The air transportation sector of the IDEAS model forecasts jet fuel and aviation gasoline use through 2030. The sector is disaggregated into commercial aircraft, general aviation, and military aircraft. The basic structure of the aircraft sector is shown in Figure 11.

\section{Commencial Aircraft Fuel Consumption}

The commercial airline sector is treated in much more detail by the IDEAS model than the general aviation and military sectors. The IDEAS commercial aircraft sector consists of a passenger demand module, which forecasts domestic and international passenger demand, and an aircraft efficiency module, which forecasts average aircraft fleet efficiency for narrow body and wide body aircraft based on an aircraft vintaging structure that tracks aircraft efficiency by year of aircraft production.

Demand For Commercial Air Transportation - Commercial aircraft demand is estimated separately for domestic and international flights. Domestic flights represent all flights originating and terminating in the United States, regardless of the nationality of the air carrier. International aircraft fuel consumption includes all flights originating in the U.S., and terminating in other countries, regardless of the nationality of the air carrier.

For purposes of modeling aircraft fuel consumption in the IDEAS model, aircraft demand has been defined as available seat mile equivalents (ASME). Available seat mile equivalents for domestic aircraft and international aircraft are calculated based on projections of revenue passenger miles, freight "passenger mile equivalents" and aircraft load factor.

The model is currently structured to allow the model user to select between two algorithms when forecasting revenue passenger miles. The basic projection algorithm is based on work performed by David Greene at Oak Ridge National Laboratory for the Aircraft Transportation Energy Model using a linear model considering GNP per capita and price. Separate demand models have been estimated for domestic and international revenue passenger miles. The IDEAS model also allows the user to specify reference case revenue passenger mile demand using alternative forecasts from sources such as the NEMS. The reference case demand is influenced by changes in aircraft yield and changes in GNP relative to the reference case using elasticities estimated at Oak Ridge National Laboratory44. This model form has the advantage of allowing the modeler to accurately replicate reference case forecasts from other sources, while still allowing appropriate representation of the impact

Commencial Aircraft Fleet Efficiency - The commercial aircraft average fleet efficiency is determined using an annual aircraft vintaging model. New aircraft efficiency is projected based on expected technology advances, and the influence of fuel price on efficiency. The efficiency of each aircraft vintage is tracked according to the year of aircraft production, and older aircraft are removed from the aircraft fleet over time due to retirement.

The aircraft vintaging structure is separated into narrow-body and wide-body aircraft. Average fleet efficiency is determined separately for domestic flights and international flights based on the ratio of narrowbody aircraft relative to wide-body aircraft used in each demand sector. Overall fleet efficiency is based on a weighted average of the wide body and narrow body fleet efficiencies.

New Aircraft Demand And Fuel Efficiency - The demand for new aircraft is based on growth in travel demand and the retirement of older planes. Currently, aircraft deliveries in time $t$ are determined by demand and aircraft inventory levels at time t-1. The model forecasts current demand based on five year trends in

44. David L. Greene, et al, Air Transport Eneray Use Model, April 1991, Center for Transportation Analysis, Energy Divicion, Oak Ridge National Laboratory. 


\section{Figure E11. Overview Of The IDEAS Aircraft Sector}

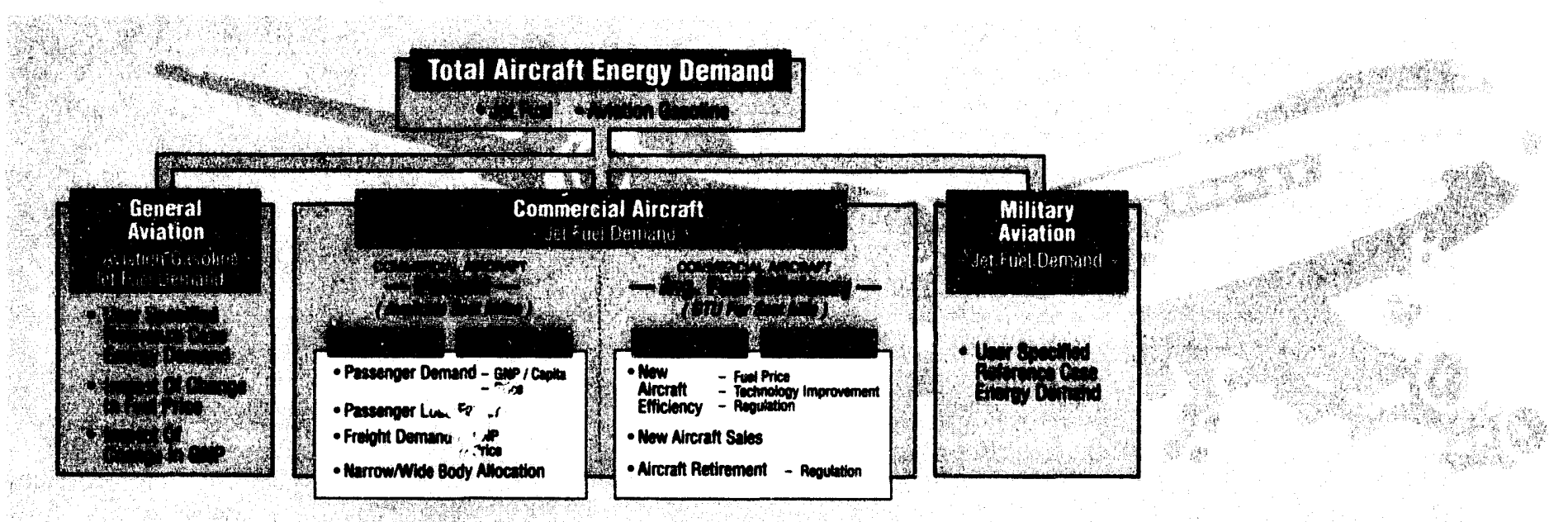

demand. If aircraft capacity is insufficient to meet expected demand in the following year, the model brings new aircraft into the fleet. At this time, the model does not attempt to project aircraft demand into the future beyond the one year time horizon. Hence, the model does not consider ordering and construction lags on new aircraft delivery.

The IDEAS model projects the efficiency of new aircraft measured in BTU's per available seat mile. Aircraft fuel efficiency increases as a function of fuel price and technology improvements over time. Expected improvements in aircraft efficiency due to changes in technology which are not dependent on fuel price are specified by the user. Current specifications include projected improvements in aircraft efficiency from known and existing technologies, and are based on work published by David Greene of Oak Ridge National Laboratory.

Air Freight - The IDEAS model projects domestic and international air freight tonnage based on GDP. Total air freight tonnage is allocated between dedicated air freight carriers, and joint passenger/air freight flights based on estimated historical percentages. Air freight shipped on passenger flights is accounted for in fuel consumption per available seat mile, resulting in no additional fuel consumption. Dedicated air freight tonnage is converted is converted to available seat mile equivalent using current aircraft transport tonnage capabilities, and then added into the demand for seat miles traveled used when determining aircraft fuel consumption.

\section{General Aviation And Military Sectors}

The IDEAS model projections of military aviation fuel consumption are specified exogenously. Reference case general aviation fuel consumption is also specified exogenously by the user, but is influenced by changes in fuel price and GDP relative to the reference case using price and GDP elasticities.

\section{Other Transportation Modes}

In addition to the highway and aircraft transportation modes, the IDEAS transportation section includes representation of waterborne transportation, rail transportation, pipeline transportation and miscellaneous other transportation energy consumption. Tbtal energy consumption in these smaller transportation modes accounted for 12 percent of transportation energy demand in 1990. Since individually each of these transportation modes account for a relatively small amount of energy consumption, the IDEAS model represents these modes in substantially less detail than the aircraft and highway transportation sectors.

Waterborne (domestic freight, international freight, and recreational) and rail (freight and passenger) transportation projections are based on user-specified reference case projections and then modified to reflect changes in GDP and fuel prices relative to reference case GDP and fuel prices. 


\section{Electriclty Generation}

The electricity generation sector of the IDEAS model represents the decisions that lead to the commitment to new generation capacity, the operation of existing capacity, and the setting of electricity rates. Figure 12 illustrates the basic structure of the IDEAS electricity generation sector, which represents electric utilities and non-utilities that sell to utilities (self-generators and industrial cogenerators are accounted for in the Industrial Sector of the model and are treated as a reduction in industrial electricity demand). The sector first determines new capacity needs based on forecasted load growth. Technologies compete for a share of this market for new capacity based on a "least-cost" algorithm. The "winning" technologies are put into construction and are eventually added to existing capacity, where they are dispatched in a "least-cost" manner to satisfy electricity loads from the demand sector of the model. Finally, all costs associated with system construction and operation are combined under traditional ratemaking rules to determine electricity prices. These prices are then fed back into the demand sector, helping to determine current and future load growth.

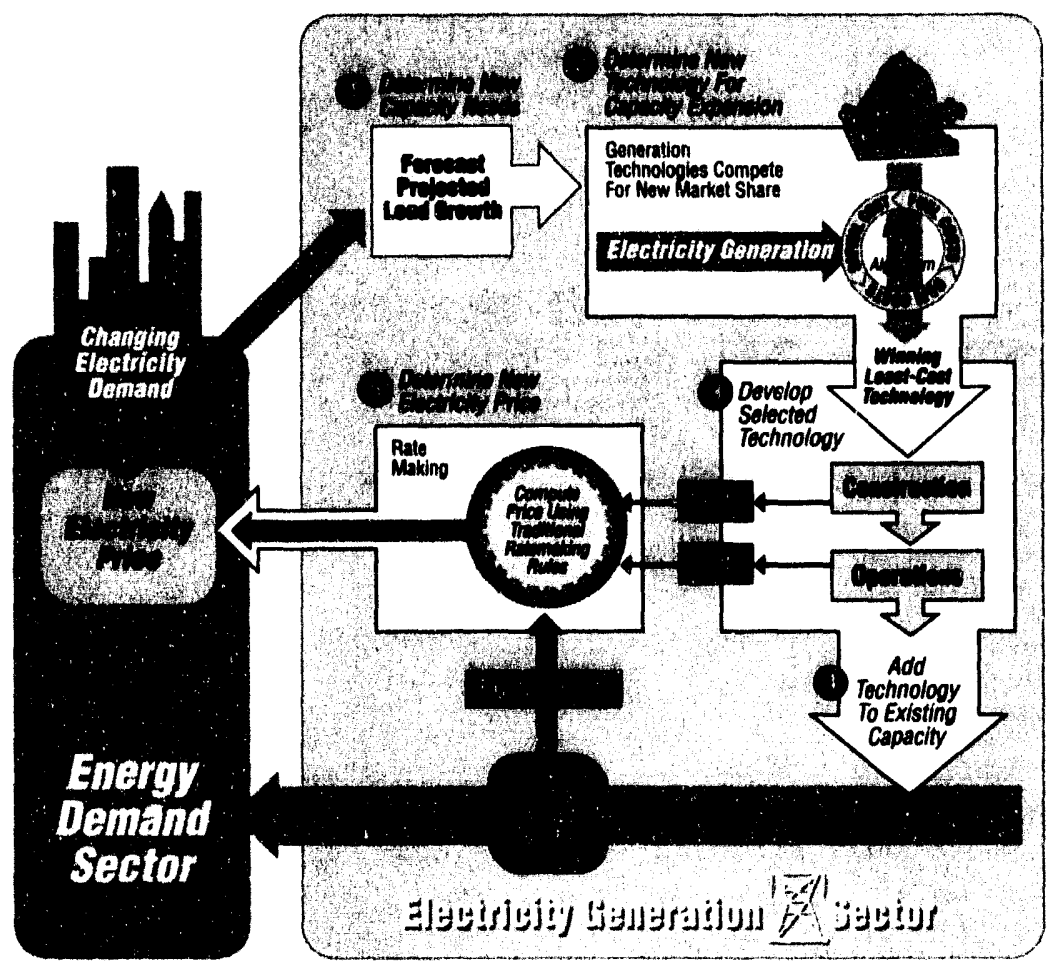

Figure E12. Electricity Sector Overview

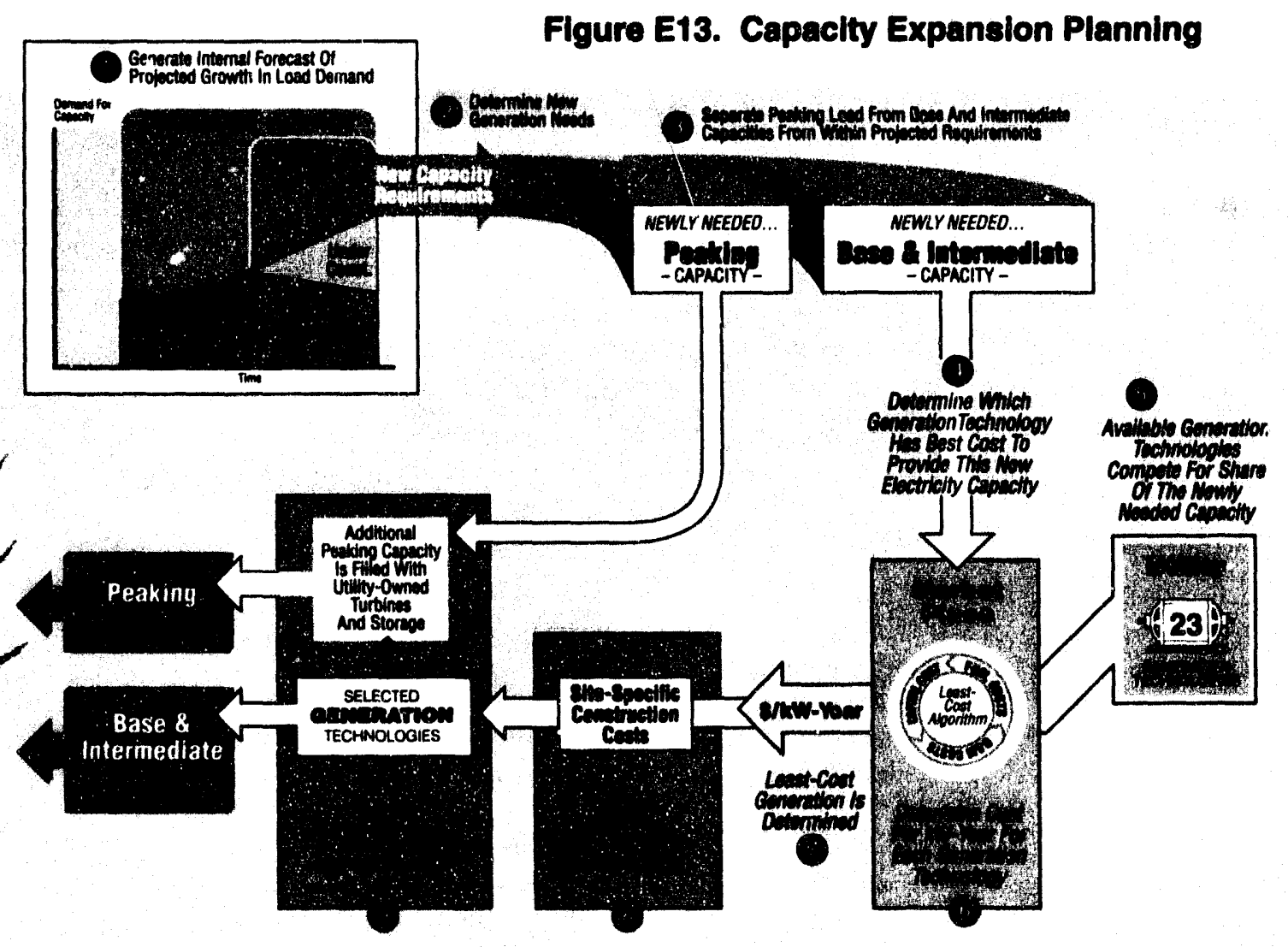


Figure 13 illustrates the model's capacity expansion planning decisions. The sector generates an internal forecast of load growth by using historic load growth over a "forecasting horizon" and extrapolating this growth over the same time horizon into the future. The forecasting horizon represents the amount of time it takes to design and construct generation capacity, typically 5 to 7 years. This forecast of load growth should not be confused with a typical long-term forecast where electricity loads are forecasted each year for the next 10 or 20 years. In IDEAS, the load forecast attempts to estimate the load at only one point in the future. With a five year forecasting horizon, the 1990 load forecast gives the expected load in the year 1995. One year later the load forecast will give the expected load in the year 1996.

This projected load is then split into a peaking component and intermediate/baseload component. These requirements are compared to existing resources (minus expected retirements) and resources currently under construction to determine new capacity needs over the planning horizon. The various technologies then compete for a share of this market for new capacity. The model includes cost and performance characteristics for 23 different types of generation technologies shown in Figure 14 (conventional hydro, pumped storage, and municipal solid waste are treated exogenously). The projected cost per kilowatt-year for each technology is calculated at each point in time from capital costs, fuel costs and non-fuel operating costs. The total costs are then used in a probabilistic market share algorithm which represents the variability in site-specific construction costs, thereby avoiding "knife-edge" construction decisions.

Combustion turbines, hydro pumped storage, and a portion of solar and wind technologies are used to fill peaking requirements, and the remaining utility and NUG technologies compete to meet the system's intermediate and baseload requirements. The model explicitly life-extends a user-specified fraction of utility oil, gas, and coal steam plants which are due to be retired. A fraction of the remaining coal plants can be "repowered" using first the Atmospheric Fluidized Bed (AFB) technology, and later the IGCC (Integrated Gasification Combined Cycle) technology when this technology becomes commercially available. The model can also convert gas combined cycle plants, ISTIGs (Intercooled Steam-Injected Gas Turbines), and natural gas fuel cells to coal-burning facilities by installing a coal gasifier when this option becomes economically attractive.

After a construction delay, newly-constructed facilities enter commercial operation and are dispatched according to the algorithm shown in Figure 15. An annualized load duration curve is used to split demand into base, intermediate and peaking load requirements. Base load is satisfied first with nuclear and base renewables (which
Figure E15. System Operation

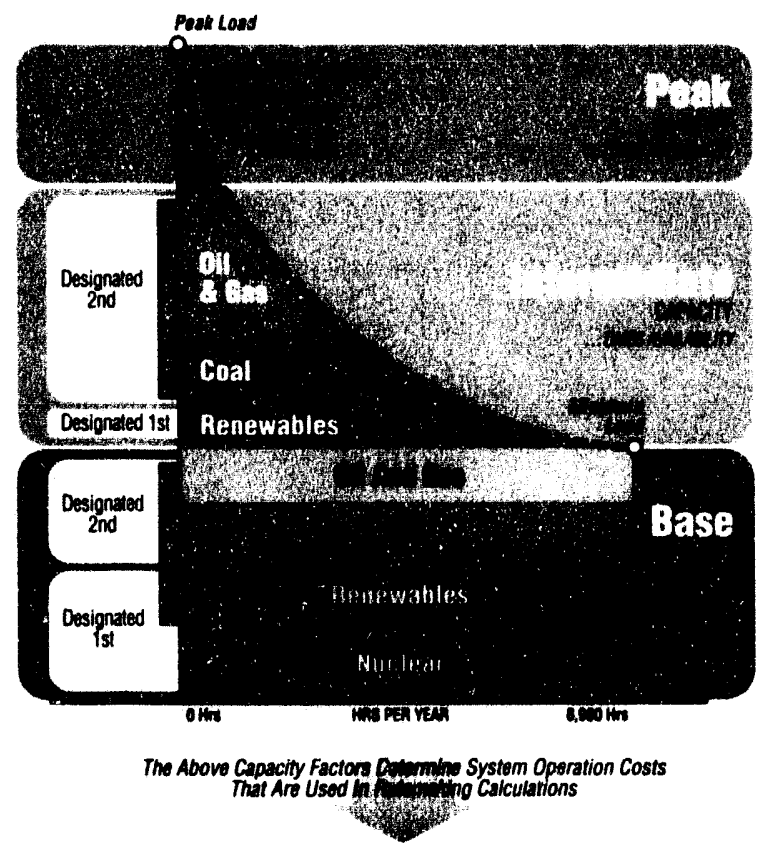


include geothermal and biomass), then with a fraction of existing coal and oil/gas capacity designated as baseload. Intermediate load is met by intermediate renewables (such as solar and wind), then by the remaining coal and oil/gas capacity which is dispatched based on the relative operating costs of these technologies. Finally, combustion turbines and storage are used to fill the remaining peaking demand as well as a small amount of photovoltaics and solar thermal. Operating costs for use in ratemaking are then calculated based on the resulting capacity factors.

The ratemaking procedure represents the traditional regulatory process and is shown in Figure 16. Allowable capital costs (including transmission/distribution assets) are accumulated in the rate base as new capacity is built and depreciated over a book life of 35 years. (Life extension and repowering costs are depreciated over 10 years). A standard industry allowed return on the rate base is then used to calculate the utility Allowed Income. Costs associated with operating the system (including fuel costs, operating and maintenance (O\&M) costs, and avoided cost payments to NUGs) are treated as Allowed Expenses. Together, Allowed Income and Allowed Expenses represent the total amount of revenues that utilities are allowed to recover from the ratepayers (called Allowed Revenues). Allowed Revenues are divided by electricity production to compute an average cents per kilowatt-hour price of electricity. End-use electricity prices are then calculated from this average price, and are used by the demand sectors of the model to determine consumer choices in end-use equipment and conservation.

Several policy options are available to the user. As is true with other sectors, all cost and performance characteristics are user-specified and can be altered to reflect the results of an R\&D program, for instance. Another policy option is to encourage utility conservation programs, which can be implemented in the model by setting a limit on what the utility is willing to spend for conservation measures and the percent of utilities which participate in conservation programs. The user chooses whether the utility expenses the costs or puts them into the ratebase (thereby getting a return on their conservation investments). The costs for these programs are determined in the demand sector by using the conservation supply curves to "look up" the conservation measures which would be cost-effective to the utility based on the utility's lower discount rate and the spending limit specified by the user. Renewable technology incentive options are also available, and are discussed in more detail in the section on renewable technologies.

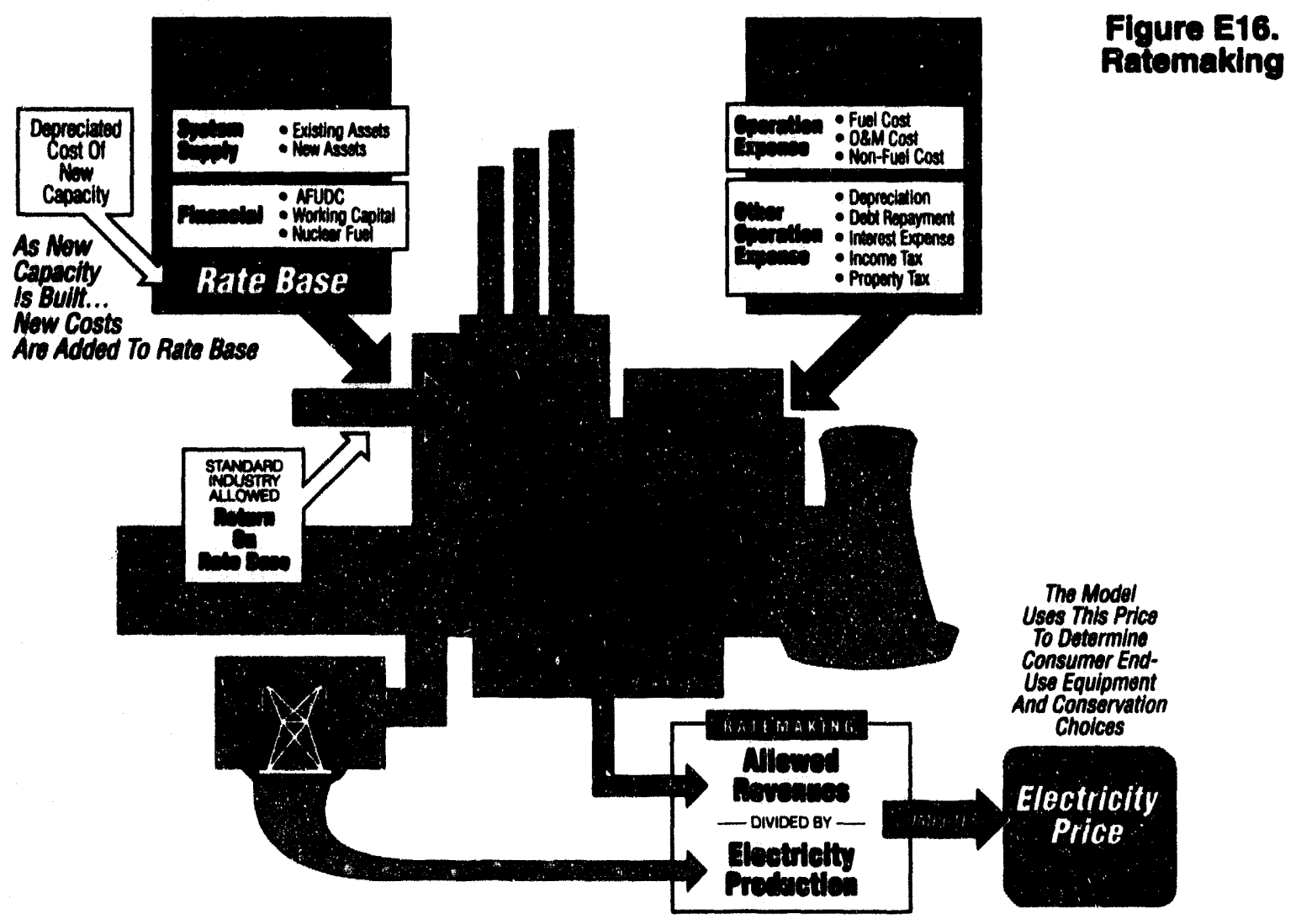




\section{Oll and Cas}

The oil and gas sector of the IDEAS model provides a rigorous and consistent framework for projecting investment, production and imports for petroleum, natural gas, and synthetic fuels. The sector also estimates natural gas price. The sector is designed to:

- Capture the long-term dynamics of fossil fuel discovery, production and depletion;

- Model the transition from rellance on conventional oil and gas resources to unconventional resources and production technologies;

- Simulate industry decision making and behavior by modeling explicitly, on an aggregate basis, the major structural elements of the domestic oil and gas industry;

- Provide a structural basis on which to analyze implications of different policies and scenarios.

\section{Major Outputs}

The major outputs of this sector of the model are oil and gas production by resource category, oil and gas imports, and domestic natural gas wellhead prices. Other significant intermediate outputs include:

- Reserves, probable reserves and remaining undiscovered resources by resource category;

- Total oil and gas industry investment by resource category;

- Marginal exploration, development and production costs by resource category;

- Drilling footage and drilling costs by resource category for wildcat and development drilling.

The oil and gas sector results are highly dependent on oil and gas demand determined endogenously by the other sectors of the IDEAS model and on several exogenous inputs, including:

- World oll prices;

- Estimated producible resources;

- Resource find rates for conventional oll and gas;

- Resource exhaustion cost impact curves;

- Maximum import capacity by source;

- Alaska oll and gas production capacity;

- Alaska natural gas pipeline capacity.

The oil and gas sector of the IDEAS model was designed and built to replicate the structure of actual energy markets, including structural representation of a wide range of existing and potential policy issues. The model can be used to review the impact of a wide variety of oil and gas production policy options including:

- Improvememts in exploration, drilling \& recovery techniques;

- Expanded secess to denied provinces;

- Oil and gas production and income tax policies;

- Covernment guarantees on new, higher risk technologies (such as coal liquids or tar sands).

The model also can be used to evaluate a number of sensitivity cases such as alternative oil price scenarios, alternative resource base estimates, high and low drilling, completion, and production cost scenarios (for example, from high and low environmental compliance costs), and high and low technology improvement scenarios. 


\section{Structure of the Oll and Gas Sector}

The three main elements of the oil and gas sector of the IDEAS model are:

An aggregate financial sector which tracks overall oil and gas industry finances, and determines funds avallable for industry investment;

- Inveatment allocation functions which determine investment among each of the oil and gas resource categories; and

For each resource category, a sector which tracks resources, estimates costs, and dotermines production.

The relationships and structural detail of each of these three elements are shown in Figure 17.

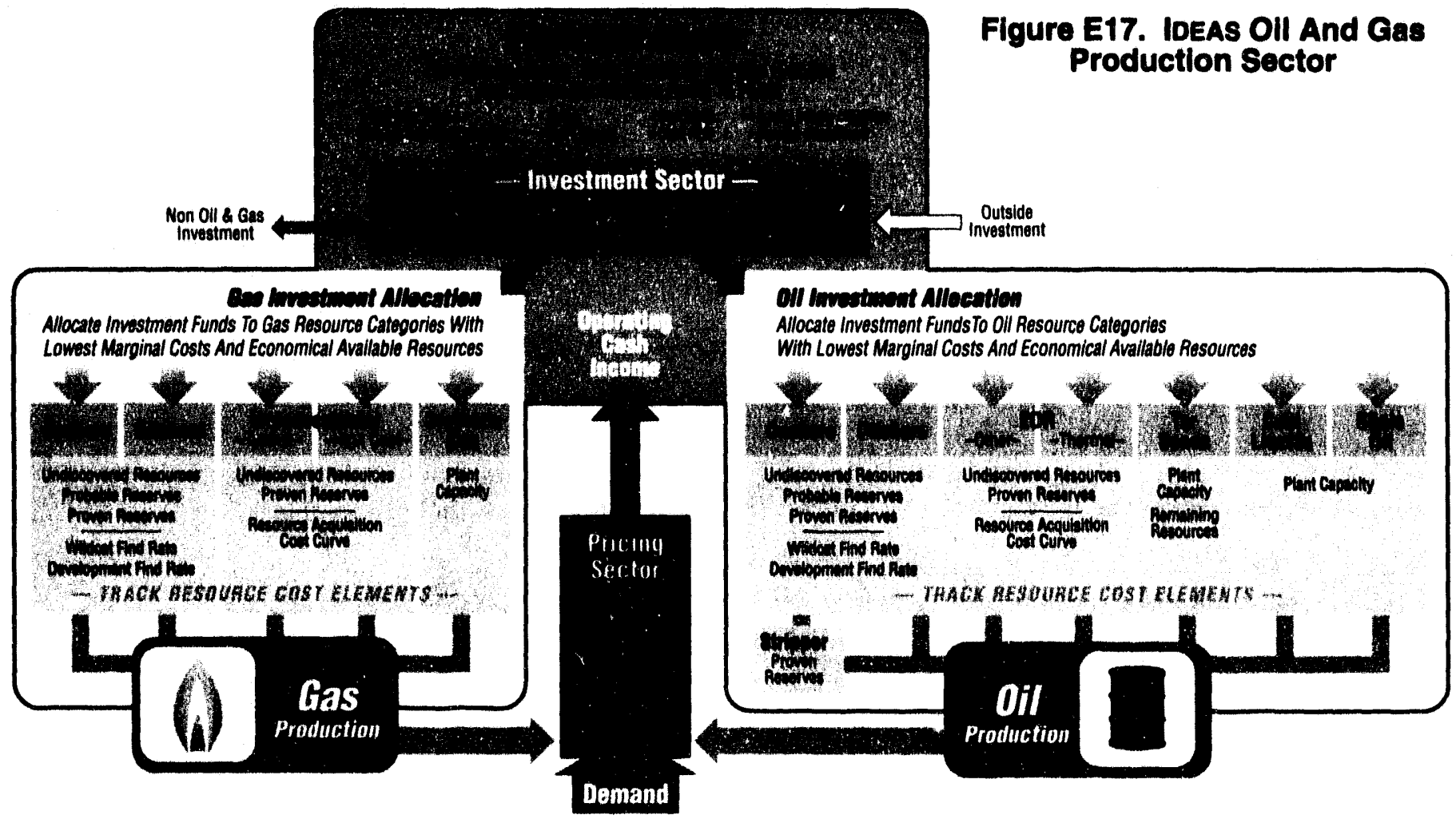

\section{Oil and Gas Prices}

Domestic oil wellhead prices are determined relative to the world oil price, and vary between resource categories to account for differences in quality and location. World oil prices are set outside the U.S. economy and are therefore input assumptions, although the model adjusts the oil price for non-reference case scenarios through a supply elasticity in response to changes in demand relative to the reference case.

Wellhead gas prices are calculated based on the price at which the development of new gas resources would be considered economic, adjusted upward or downward to reflect market conditions. The base resource price reflects marginal resource costs inflated to account for royalties, severance taxes, and state and federal income taxes. The marginal resource costs of each resource category is calculated using a discounted cash flow model which explicitly considers revenues, expenditures, and tax treatment of expenditures.

Average oil and gas wellhead prices are converted into end-user prices with the addition of processing and transportation costs. The end-user prices feed back in each time period to the demand sectors in order to clear oil and gas markets. 


\section{Oil and Gas Financial Soctor}

The financial sector tracks overall oil and gas industry financial flows and determines available funds for investment. Taxes, dividends, debt payments, debt issued, and operating cash income are modeled explicitly to determine total funds available for investment. The financial sector also calculates return on equity and return on investment to estimate revenue flows between the oil and gas sectors and other sectors of the economy.

\section{Investment Allocation Sectors}

The investment allocation logic simulates on an aggregate basis the basic factors influencing actual industry decision-making. The model determines investment at the technology/resource category level based on the relative attractiveness of different investment options and the size of the identified opportunities for profitable investment. The profitability of each resource category is estimated using a discounted cash flow analysis which considers investment costs, operating costs, taxes, and expected revenues for an average project over an average (15-25 year) project lifespan.

Investment in new technologies such as coal liquids is constrained by limits on infrastructure resulting in maximum investment growth rates.

\section{Representation of Resource Categories}

The resource categories and technologies included in the model are listed in Figure 18. These categories were chosen for policy considerations or because of fundamental differences in structure, cost parameters or exfected investment behavior. In selecting the resource categories, the expected benefits of modeling an additional resource category or technology were balanced against the increase in modeling complexity and cost entailed by the additional structure.

The IDEAS Oil and Gas sector is disaggregated into 13 different resource categories or technologies for producing petroleum liquids, and 10 for producing natural and synthetic gas. The disaggregation includes three geographic regions for conventional oil and gas production: Alaska; the Gulf of Mexico; and the other Lower 48 States.

Figure E18. Resource Categories In The Oll And Gas Sector

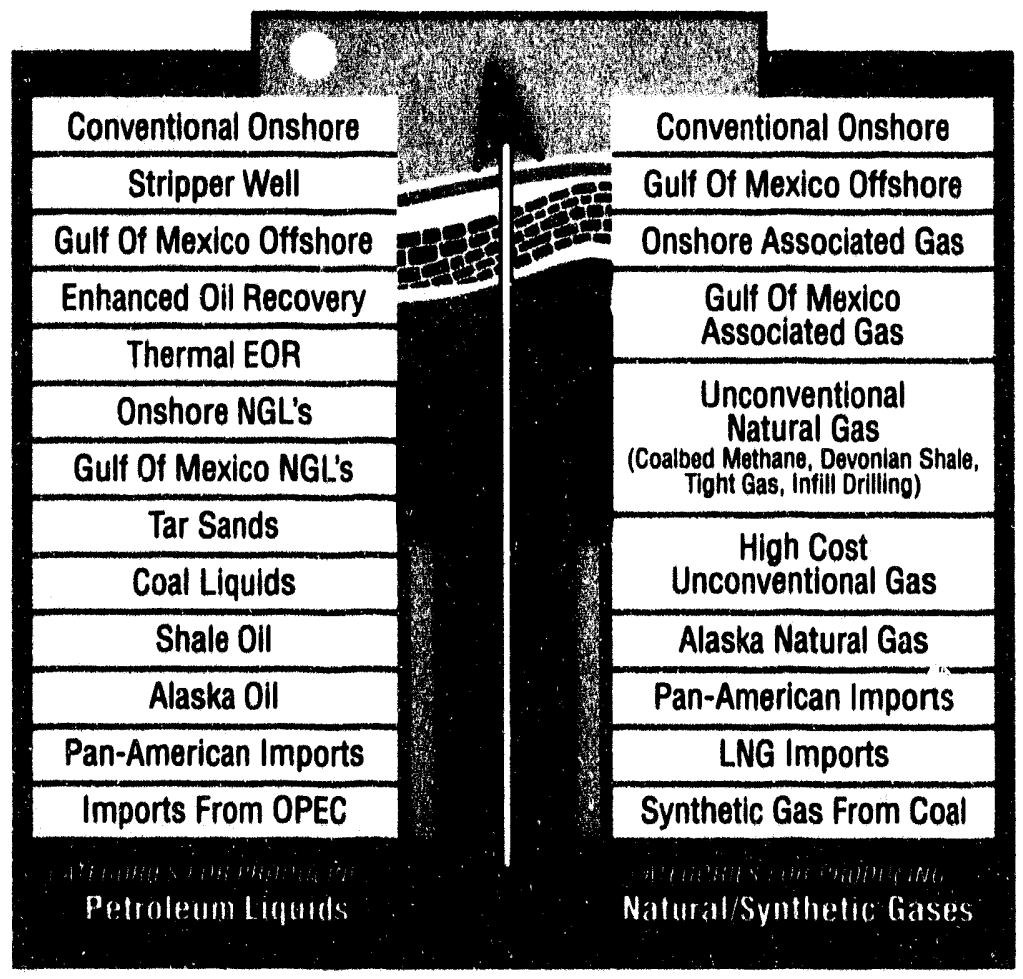


Structure of the Conventional Oil and Gas Resource Categories - Conventional oil and gas production is disaggregated by onshore and offishore regions. The general structure for these resource categories is described below, and shown in Figure 19.

For each category, the model tracks resources from undiscovered recoverable resources, through probable (or inferred) reserves, to proven reserves. Production capacity is determined by the level of proven reserves and the estimated reserve-production profile for each category.

Investment in each category is determined according to relative profitability, the potential magnitude of profitable investment, and limits on the availability of investment funds. For each category, the model estimates:

Drilling costs;

- Equipment costs;

- Geological and goophysical costs;

Lease bonuses and acreage rental costs;

- Industry overhead costs; and

Drilling footage for both wildcat and development drilling.

Figure E19. Conventional OII And Gas Production Structure

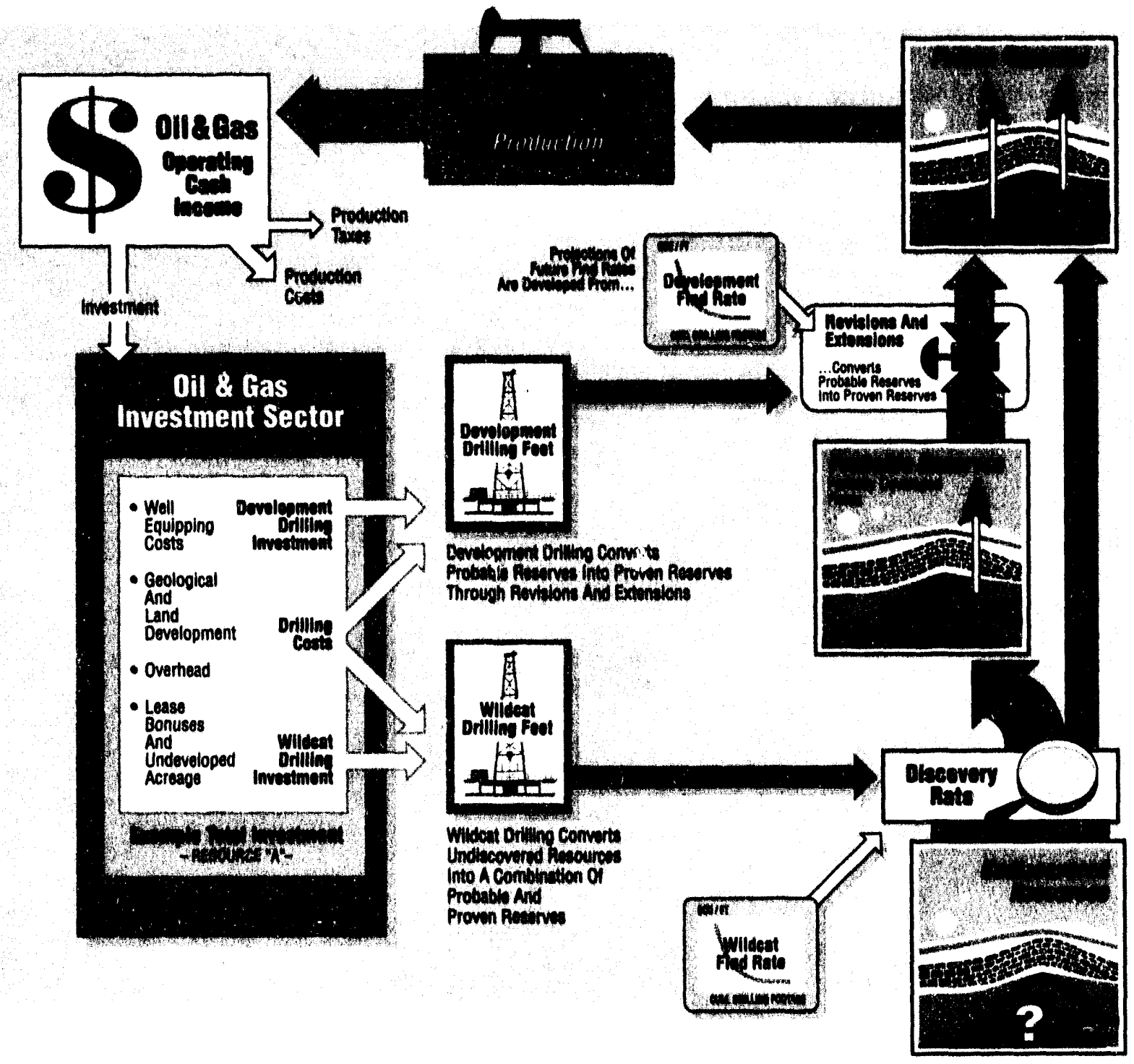


Wildcat drilling footage converts undiscovered resources into a combination of probable and proven reserves, based on wildcat find rates developed for each resource category. Development drilling results in revisions and extensions to proven reserves, converting probable reserves to proven reserves.

The projections of future find rates for conventional onshore and offithore oil and natural gas discovery were developed from the results of a much more disaggregated findrate analyais performed by EEA, Inc. This analysis was done by 20 field size classes for four drilling depth intervals of twelve onshore regions and four water depth intervals in the Gulf of Mexico. The agregrated find rates for the onshore and offehore regions in the IDEAS model approximate the drilling activity and general productivity trends (BOE/At) of the disaggregated find rate analysis.

The structure and parameters for the cost elements have been determined separately by analyzing historical data from the American Petroleum Institute (Survey on Oil and Gas Expenditures, Basic Petroleum Data Book) and other sources. The historical data on production and reserves used in the model are based primarily on Energy Information Agency (BLA) and American Petroleum Institute data sources. The resource base estimates are derived from the 1988 U.S. Geological Survey assessment.

Structure of the Nonconventional Oil and Gas Resource Categories - The nonconventional resource categories have been modeled in a simpler fashion. Production from the synthetic fuel categories is constrained by accumulated production capacity, which is increased by new capacity investment and reduced by capacity retirements. This type of structure is used to represent coal liquids, tar sands, and synthetic natural gas.

The structure of the other nonconventional resource categories (unconventional and high-cost unconventional natural gas, thermal BOR, and other EOR) is based on a simplified version of the resource based structure used for conventional oil and gas. The resource base for these categories has been simplified to include only potential resources (aggregating undiscovered resources and probable reserves), and proven reserves. Additions to reserves are determined by the level of investment. The determination of resource costs considers remaining potential resources, drilling costs, changes in resource technologies, etc.

For each of these categories, a resource investment cost curve has been derived which determines the baseline cost of converting one unit of undeveloped resource into proven reserves. The cost curves are based on detailed resource base analysis where available, published cost estimates, and other sources. As resources are depleted in each category, the cost of adding additional reserves increases.

\section{Oll and Gas Import Structure}

Natural gas imports (pipeline and LNG) are the marginal or last-resort source of natural gas supply, and are limited by maximum import capacity. Minimum gas imports are determined as a percentage of available import capacity. LNG import capacity is determined based on existing capacity and potential for expansion of existing capacity through the year 2010. After 2010, additions to LNG capacity are related to increases in domestic gas prices. Natural gas pipeline import capacity is an exogenous input to the model.

Net oil imports are equal to the difference between domestic demand and domestic supply.

\section{Coal Production}

The coal production sector of IDEAS simulates the operation of existing coal mining capacity, the creation of new mining capacity, and the setting of long-term delivered prices for coal. Figure 20 illustrates the basic structure of the IDEAS coal sector. The coal mining industry is represented as one aggregate entity with two production methods - surface mining and underground mining. This entity produces coal, collects revenues, pays expenses, sets prices, and makes decisions about how to expand production to meet future growth in demand.

The model determines how much investment in new production capacity is necessary to keep capacity utilization within acceptable limits. Industry investment in now production capacity can be constrained if, for some reason, internal funds plus available financing are not able to cover the cost of required capacity. Coal 


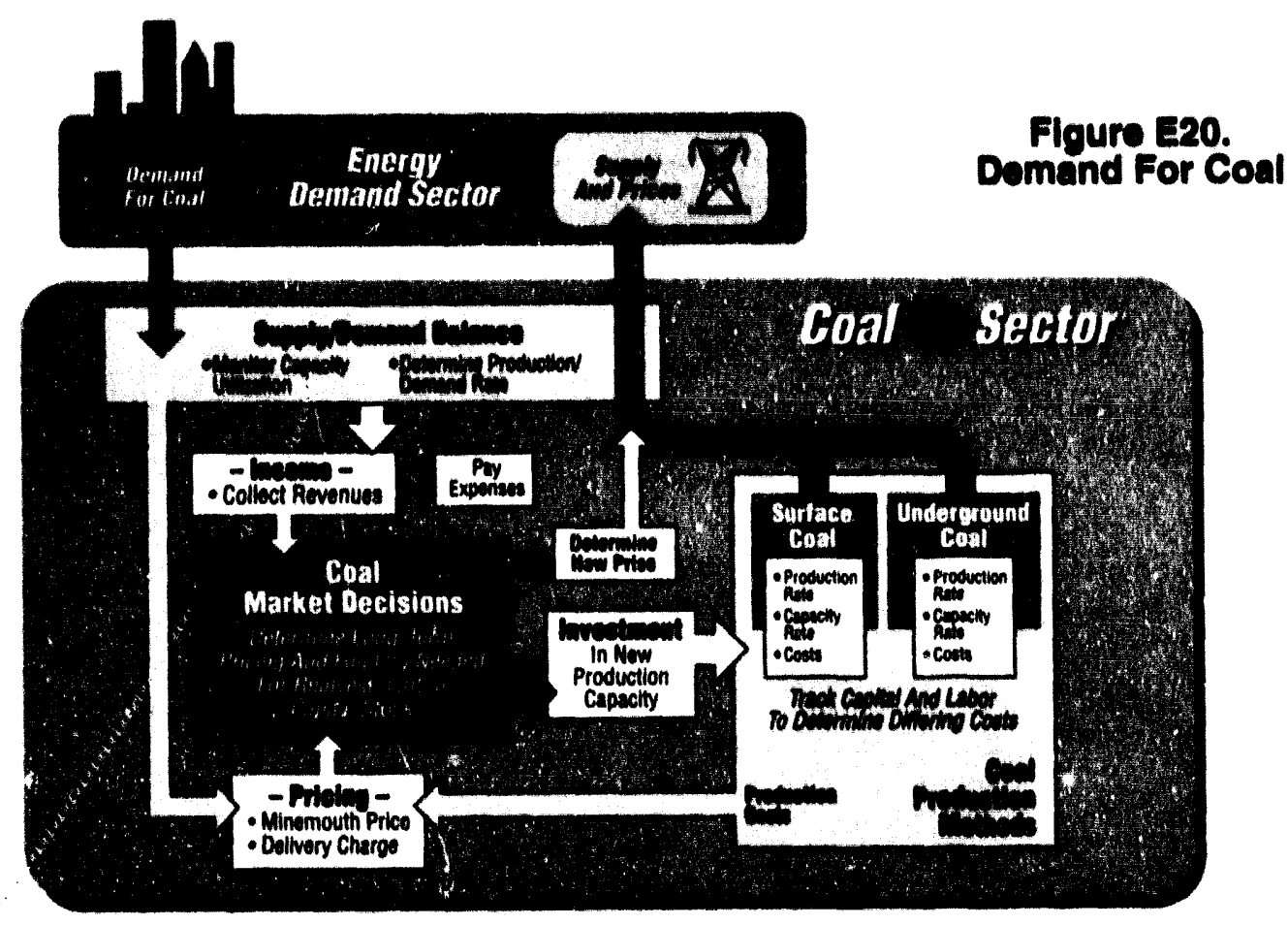

prices are generally cost-based and include components for the average cost of production, return on equity, and a delivery charge, although profits (return or equity) may escalate if production capacity has difficulty keeping up with demand.

Mining capacity is maintained separately for surface and underground mines because of the inherently difforent capital and labor components of total production costs for these two methods of prorluction. Production costs for both methods escalate as reserves are depleted, which "feeds back" to escalate the minemouth and delivered coal prices. The delivered coal price is, in turn, fed back to the demand (and other energy production) sectors, where the decisions are made about future fuel choices. This price feedback makes the IDEAS model's different sectors interdependent (for example, oil prices affect coal prices).

The coal pricing algorithms calculate the minemouth and delivered prices of coal as shown in Figure 21. The normal minemouth coal price is computed as the average cost of coal production plus a profit margin. The

Flgure E21. Computation Of Coal Price

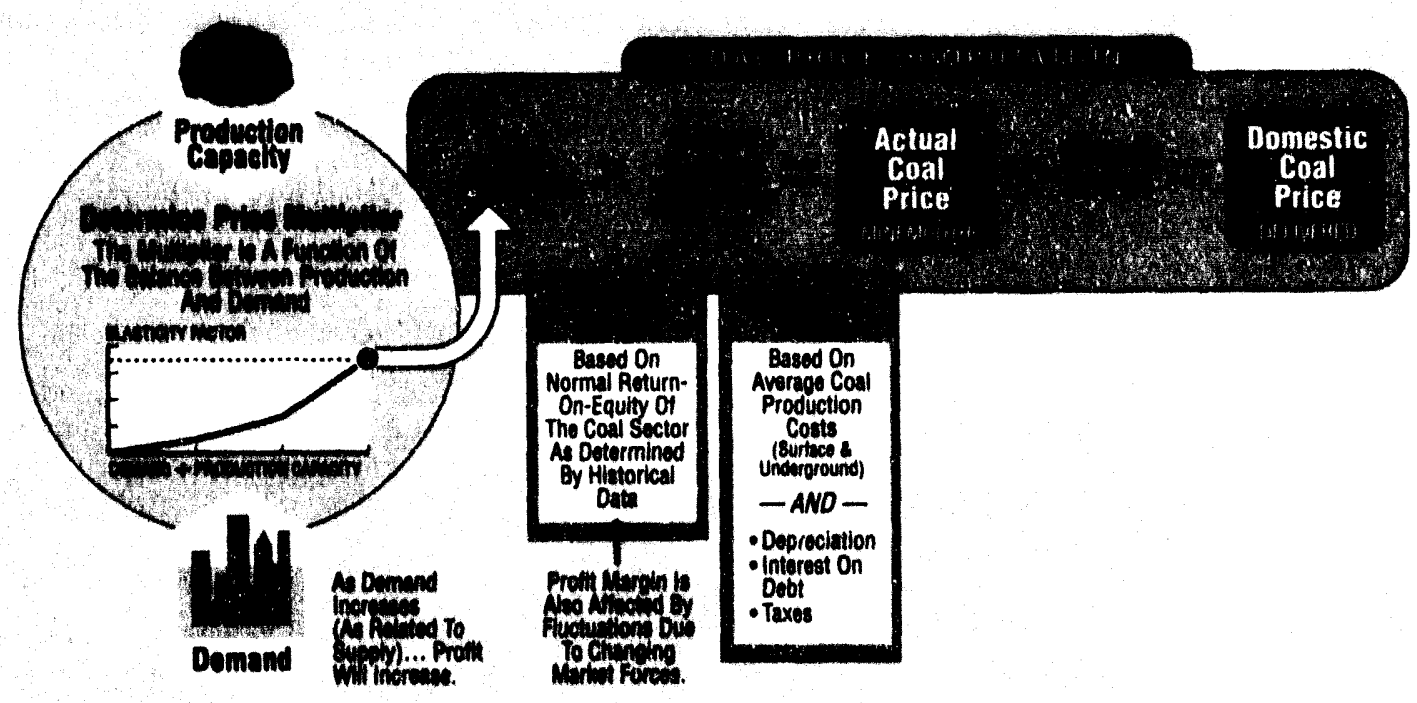


industry's average cost is computed as the weighted average of the operating costs of surface mining and underground mining, plus depreciation, interest on debt and taxes. The profit margin is based on a returnon-equity determined as normal for the coal sector based on historical data. The actual profit margin (and, therefore, the price of coal) will fluctuate in response to changing market forces. An elasticity factor (the price multiplier), determined as a function of the balance between production capacity and demand, is multiplied by the normal industry price to yield the actual price for coal. Therefore, as demand increases relative to supply, profit margins will increase, and price - the sum of the coal industry's average cost and profit margin - also will increase.

Funds used in capital investment (to open new coal mines) consider both the funds available to the industry and the funds actually needed by the industry, as shown in Figure 22. Funds needed for investment are determined from projected demand, projected production capacity, desired capacity utilization, and the cost of new capacity. The model internally calculates historic demand growth over a "projection horizon," and

\section{Flgure E22. Coal Industry Investment Process}

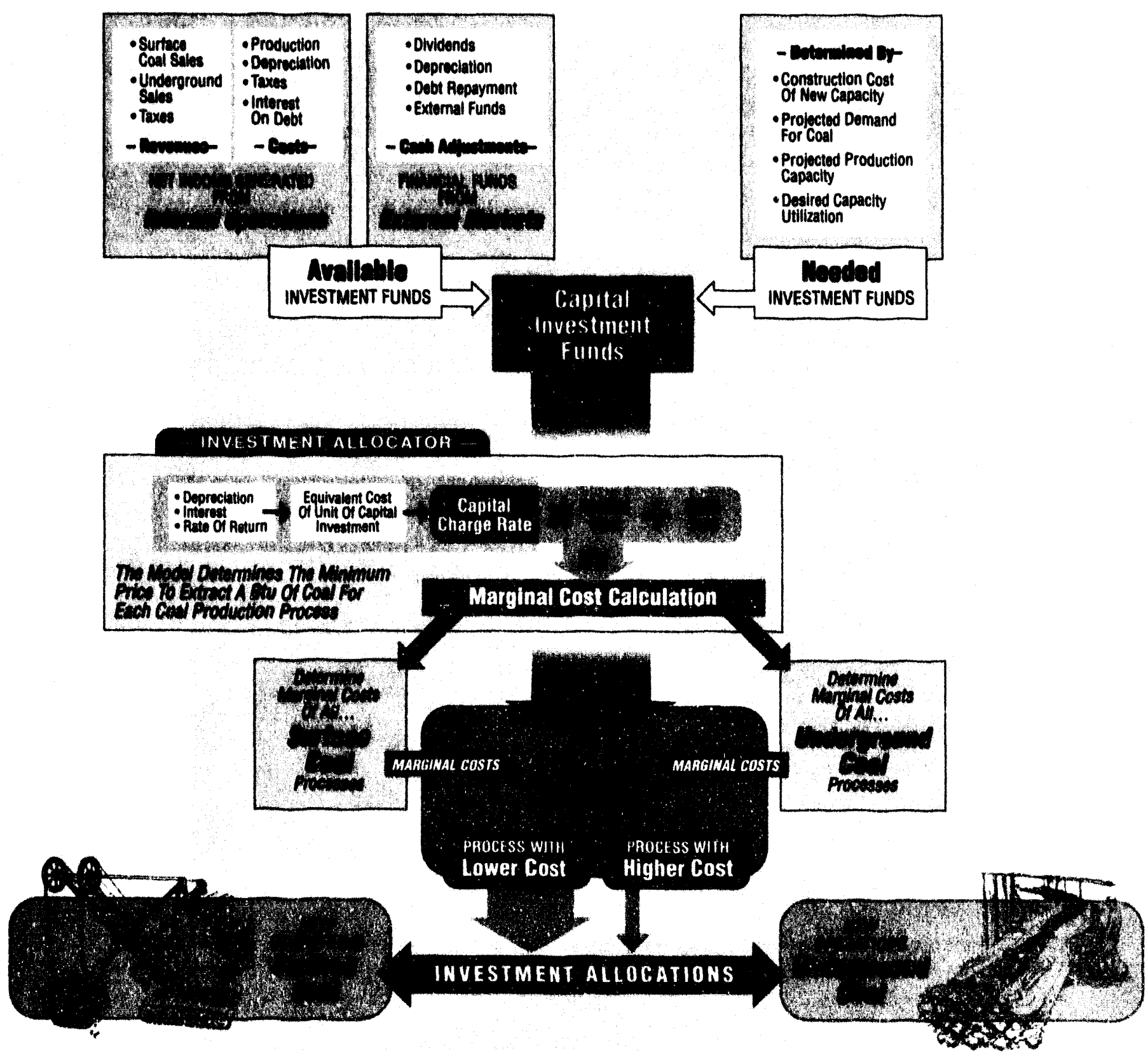


Figure E23. Internal Projection Of Now Production Requirements

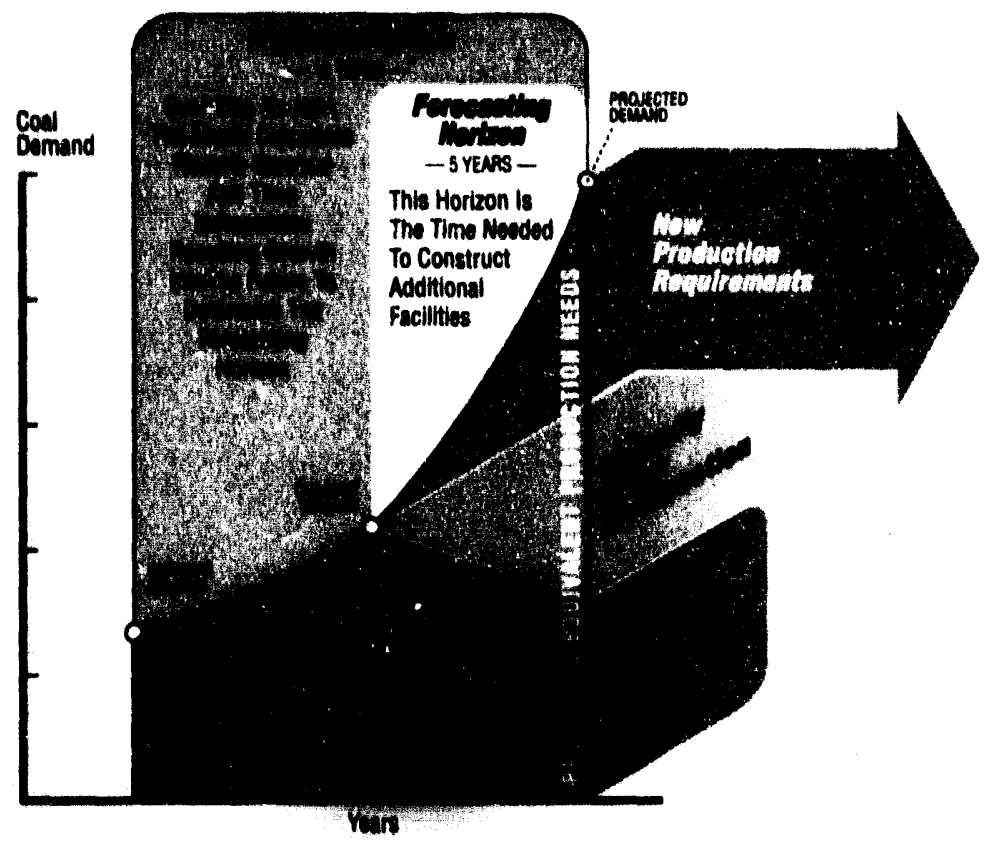

extrapolates this growth into the future (see Figure 23). The forecasting horizon represents the amount of time it takes to construct new production facilities. This projected demand is converted to an equivalent production capacity, and current production capacity (minus retirements) and capacity under construction are subtracted from it to compute new production requirements. Funds needed for construction are simply the cost of these new production requirements.

Funds available for construction of new capacity are those funds generated by internal operations plus the funds the coal industry can command in external financial markets based on its size (assets) and profitability (return on investment). If the coal industry has more funds available than are needed, the industry will invest only what is needed. However, if the funds desired exceed the amount available, the industry is constrained to invest only those funds that are available.

Funds are then allocated to either surface or underground mining. The investment allocation structure calculates a marginal cost for each production process and allocates more funds to the process that has the lowest marginal cost. The marginal cost is equal to a capital charge rate times a capital cost, plus O\&M costs. The capital charge rate is computed as a function of the depreciation, interest, and required rate of return on equity in the industry. This rate represents the annual equivalent cost of a unit of capital investment.

Figure E24. Coneric Coal Production Sector

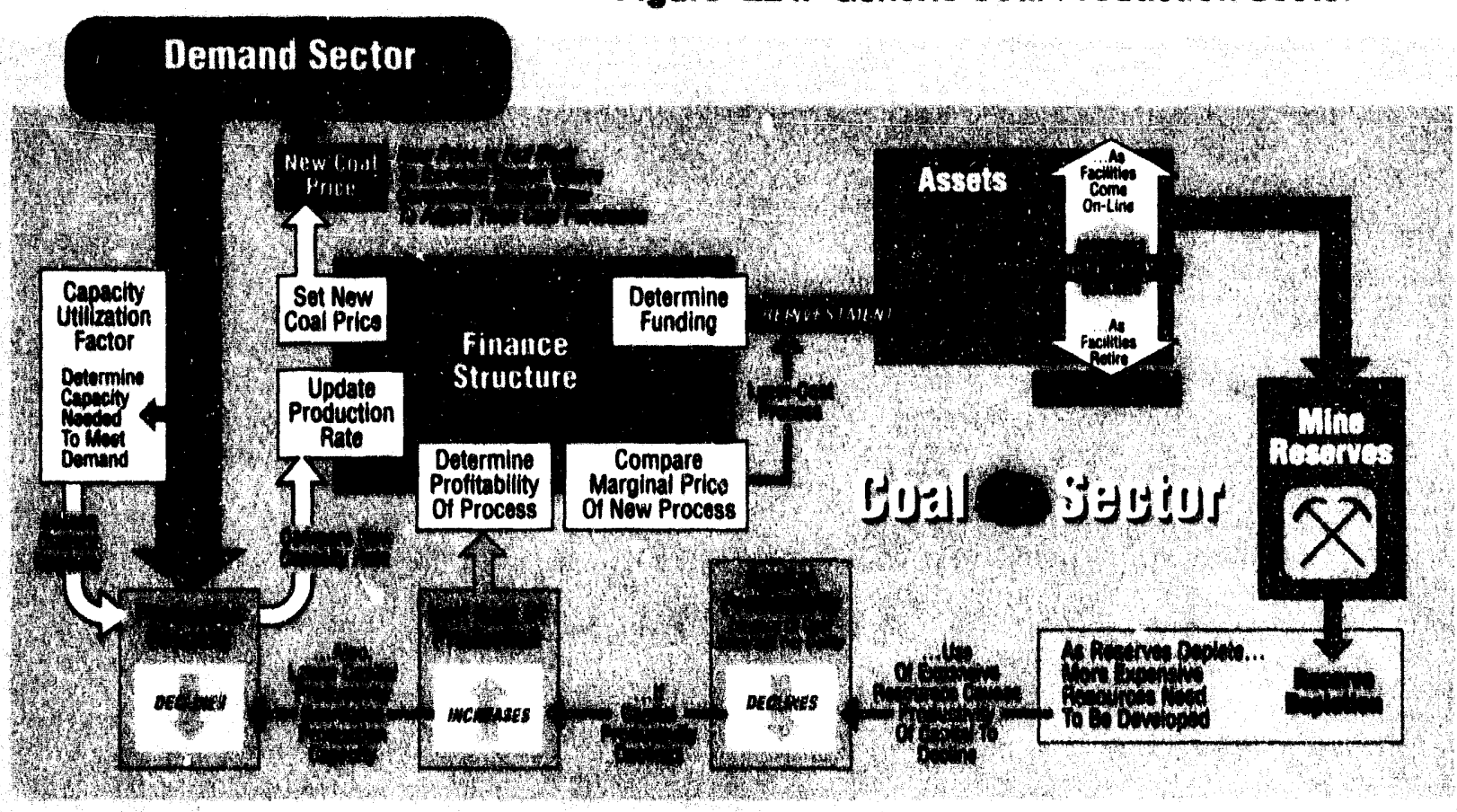


The marginal cost is the minimum price needed to extract the next Btu of coal. It includes all relevant costs and a required rate of return. This cost increases as reserves are depleted.

The structure of the coal production sector is shown in Figure 24. Funds invested annually in each process (either surface or underground production) result in the construction of new coal mines (capital stock). These assets increase in number as newly-constructed facilities come on-line and decrease as assets are retired. The asset retirement rate represents the actual wearing out of physical equipment; it should not be confused with the depreciation rate calculated in the financial structure. Finally, note that the physical assets in the production structure are not affected by inflation. These assets represent equipment "out in the field" and, therefore, are unaffected by inflationary changes.

As the most easily obtained coal reserves are depleted, the more expensive, hard-to-find resources must be exploited. Capital productivity (a measure of the amount of coal that can be extracted per dollar of capital) consequently declines (all else equal), increasing the unit cost of production and decreasing production capacity (assuming no change in the size of the capital stock). The capacity utilization factor determines how much of production capacity must be used to satisfy demand (and therefore determines the production rate). The production costs are used in the finance structure to determine the relative profitability of the process and its ability to attract new funds. Production costs are also used to determine the price of coal. The price, in turn, is fed back to the demand sector, where consumers make decisions about how much coal to consume.

\section{Ronewables}

Renewable energy sources are represented in the IDEAS model in two groups: those that are dispersed (located at the energy user's facility) and those that are used to generate electricity for a utility. The former are included in the demand sector, while the latter are located in the electricity sector of the model. Figure 25 shows the renewable technologies included in each of these groups.

With the exception of biomass, the largest role of renewables is projected to be in electricity generation. In the model, renewable technologies compete with conventional electricity generation tuchnologies for a share of the generation supply market. As described in the discussion of the electricity sector, supply technologies are compared on a $\mathbf{k W}$-year cost basis, which includes capital, fuel, and O\&M costs. A probabilistic function is used to determine market share both here and in the demand sector, which represents variability in technology costs and avoids "knife-edge" investment decisions. Renewables tend to be more expensive in initial construction, but often have lower operating costs. Their attractiveness therefore often increases as energy prices rise. Some

Figure E25. Ronewable Technologles In IDEAS

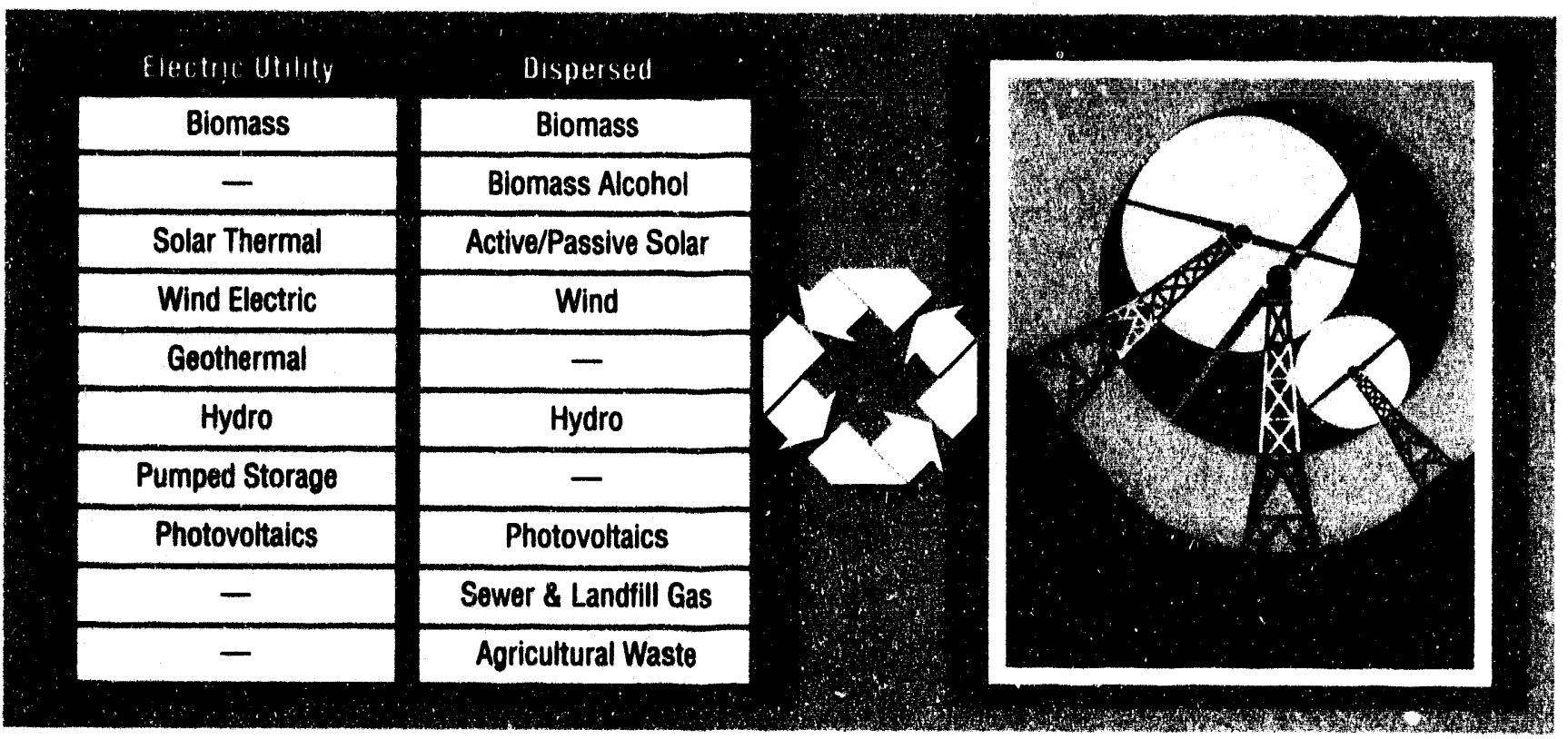


of the renewable technology costs are assumed to increase as they gain market share (for example, geothermal resources located primarily in the West) because the best sites are assumed to be used first.

The renewable technologies compete with base load technologies for market share. The only exceptions are photovoltaics and solar thermal, which are allowed to compete with combustion turbines for a limited share of peaking capacity. The solar and wind technologies are assumed to have a gas turbine backup which can be run up to $25 \%$ of the facility's total output. All the renewable technologies are run at full capacity to meet system load.

Several policy options are available in the electric generation sector of the model to encourage renewable technology penetration into the marketplace. For instance, when comparing the economics of various technologies, utilities may place a premium on those technologies which have little or no impact on the environment. This premium is known as an "externalities credit" and can be placed on any of the renewable technologies which compete for market share in IDEAS. The credit simply makes the economics of the renewable technologies more attractive resulting in more new market share.

Another policy option available in the model is a renewable electric technology production incentive. This incentive is used to decrease the marginal cost of various renewable technologies, allowing them to compete more favorably with fossil-fueled technologies for new market share. Investment tax credits are also provided in the model, again reducing the cost of renewables and making them a more attractive option for electric generation.

Hydropower, pumped storage and municipal solid waste (MSW) are treated exogenously in IDEAS because each has unique characteristics that make a strict economic comparison with other technologies inappropriate. Most hydropower plants were constructed decades ago, and there are few large new sites that are likely to be developed. In addition, the relicensing of hydro facilities is dependent on non-economic factors. Pumped storage facilities are very site-specific, and their economics vary greatly among utilities, depending on the utility's load factor and resources used for baseload generation. Since a major part of the revenues for MSW facilities comes from tipping fees for waste disposal (in addition to revenues from electricity generation), the future economics of this technology are region-specific. Furthermore, MSW usually competes primarily as a waste disposal alternative rather than an electricity generation alternative; it therefore does not compete directly with other generation capacity. MSW is therefore treated exogenously in the model.

Some of the dispersed renewables also produce electricity, but most are used directly for heat. Examples of electric dispersed technologies are wind and photovoltaics that can be installed in residential or commercial buildings for self-generation, or industrial small hydro. These are estimated exogenously and the electricity produced from these sources is subtracted from total electricity demand in these sectors.

Biomass, in the form of wood logs or wood residue, is a major form of renewables use. Wood is burned in residential buildings primarily as a space heating fuel. Because it is often used as a supplemental fuel rather than as a primary heat source, wood does not compete for market share explicitly, but is specified directly in the model. The heat provided by wood is then subtracted from total space heat demand to derive the remaining unsatisfied demand that must be met by other fuels. In industry, wood by-products (including black liquor in the paper industry) are used for producing steam. Biomass is assumed to be a free fuel, but it competes for only the share of the total steam market that represents the paper and wood products industries.

Active solar thermal systems are used for space and water heating in buildings and are assumed to have electric backup systems. The total life-cycle costs of these systems are endogenously compared to conventional systems in the model to determine their market shares. Passive solar housing designs that minimize heating and cooling needs are treated exogenously.

Alcohol fuels, which in part are derived from biomass, are included as alternative fuels in the transportation sector for light and heavy duty vehicles. Total demand for methane and alcohol fuels is calculated from the projected number of these types of vehicles, the number of miles traveled per vehicle, and the fleet efficiency, as computed in the transportation sector of the model. The amount of biomass-based fuel is assumed to be a constant fraction of total methane/alcohol fuel use. 
Miscellaneous other renewables, such as sewer and landfill gas or agricultural wastes, are treated exogenously. However, the energy provided by these sources is used to satisfy energy service demand and therefore displaces conventional fuels in the IDEAS energy projections.

\section{References}

American Petroleum Institute. 1993. Basic Petroleum Data Book. Washington, DC.

American Petroleum Institute. 1985. Well Completions and Footage Drilled in the United States 1970-1982. Washington, DC.

American Petroleum Institute. Annual. Survey on Oil and Gas Expenditures. Washington, DC.

American Petroleum Institute, American Gas Association, and Canadian Petroleum Association. 1980. Reserves of Crude Oil, Natural Gas Liquids, and Natural Gas in the United States and Canada as of December 31, 1979. Washington, DC.

Bunch, David S., Bradley, Mark, Golob, Thomas F., Kitamura, Ryuichi, and Occhiuzzo, Gareth. 1991. "Demand for Clean-Fuel Personal Vehicles in California: A Discrete-Choice Stated Preference Survey", prepared for presentation at the Conference on Transportation and Global Climate Change: Long Run Options, Asilomar Conference Center, Pacific Grove, California, August 26, 1991.

ICF Resources, Inc. 1990. Analysis of Selected Energy Security Issues Related to U.S. Crude Oil and Natural Gas Exploration, Development, Production, Transportation, and Processing.

Lovins, A. 1976. "Energy Strategy: The Road Not Taken," Foreign Affairs 55 (October 1976): 65-96

National Research Council. 1989. U.S. Production of Liquid Transportation Fuels: Costs, Issues, and Research and Development Directions. Washington, DC.

NES (National Energy Strategy). 1991/1992. Department of Energy. Integrated Analysis Supporting the National Energy Strategy. Methodology, Assumptions and Results (Technical Annex 2).

Sant, R.W., Bakke, D.W., and Naill, R.F. 1984. Creating Abundance: America's Least-Cost Energy Strategy (New York: McGraw-Hill)

Science Applications International Corporation. 1990. Draft Renewable Energy Technology Characterizations. Alexandria, VA.

Train, Kenneth. 1986. Qualitative Choice Analysis. The MIT Press, Cambridge, Mass.

U.S. Department of Energy, Office of Fossil Energy. 1988. Oil Research Program Implementation Plan. [DOE/FE-0188-P]

U.S. Department of Energy, Office of Policy, Planning and Analysis. 1988. An Assessment of the Natural Gas Resource Base of the United States. [DOE/W-31109-H1]

U.S. Department of the Interior, Bureau of Land Management. 1991. Arctic National Wildlife Refuge, Alaska, Coastal Plain Resource Assessment. Washington, DC.

U.S. Energy Information Administration. 1993a. Annual Energy Outlook 1993. Washington, DC. [DOE/EIA-0383-90]

U.S. Energy Information Administration. 1993b. Assumptions for the Annual Energy Outlook 1993. Washington, DC. [DOE/EIA-0527-90]

U.S. Energy Information Administration. 1992c. Annual Energy Review 1993. Washington, DC. [DOE/EIA-0384-92] 
U.S. Energy Information Administration. 1993d. Natural Gas Annual 1992. Washington, DC. [DOD/ELA-0131-92]

U.S. Energy Information Administration. 1993e. Petroleum Supply Annual 1992. Washington, DC. [DOE/LIA-0340-92]

U.S. Environmental Protection Agency. 1990. National Air Quality and Emissions Trends Report, 1988. Research Triangle Park, NC. [EPA-450/4-90-002]

U.S. Geological Survey and Minerals Management Service. 1989. Estimates of Undiscovered Conventional Oil and Gas Resources in the U.S.: A Part of the Nation's Energy Endowment. 

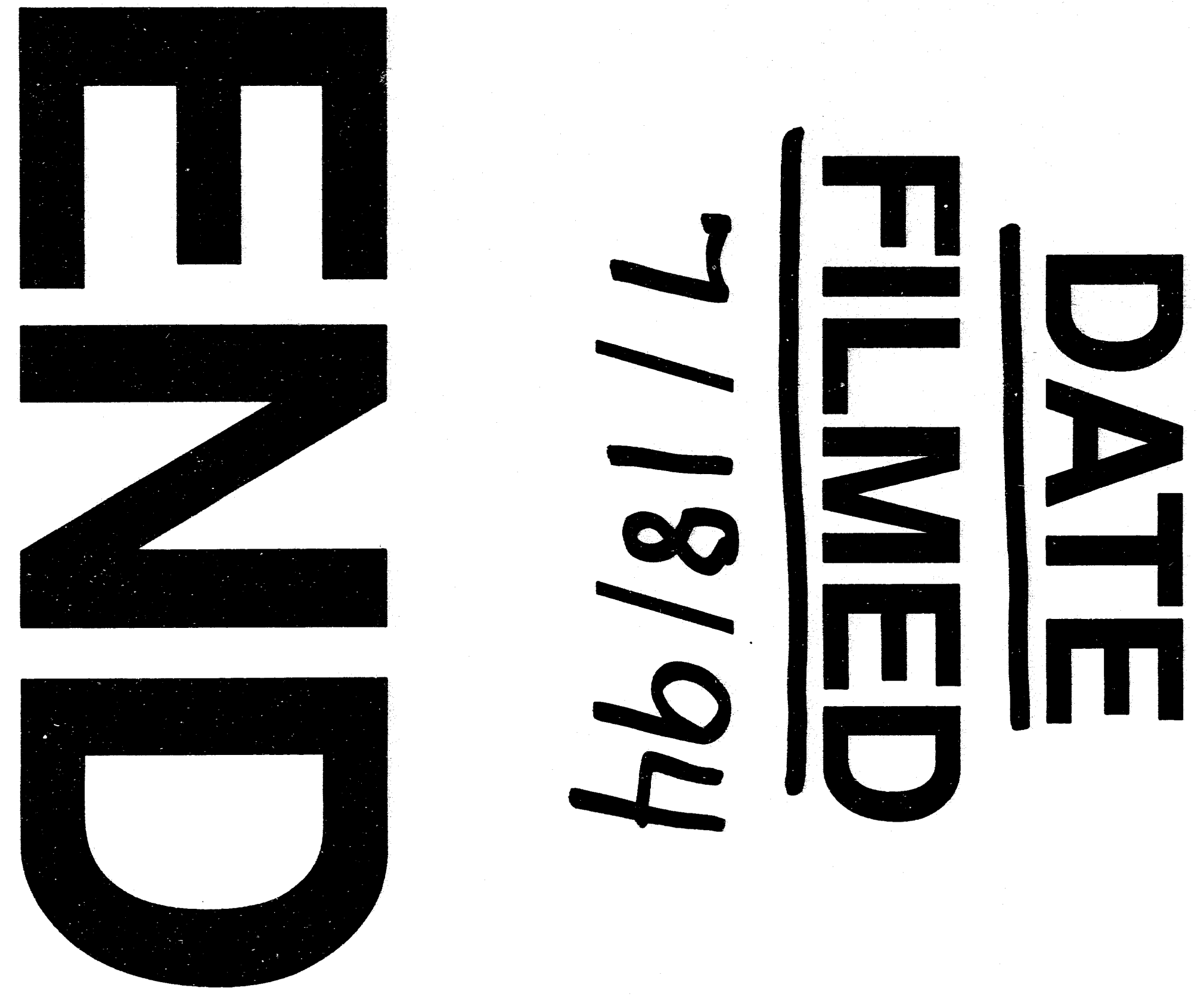
